Prepared in cooperation with the

Massachusetts Department of Environmental Protection, Division of Watershed Management

\title{
Nutrient and Sediment Concentrations, Yields, and Loads in Impaired Streams and Rivers in the Taunton River Basin, Massachusetts, 1997-2008
}

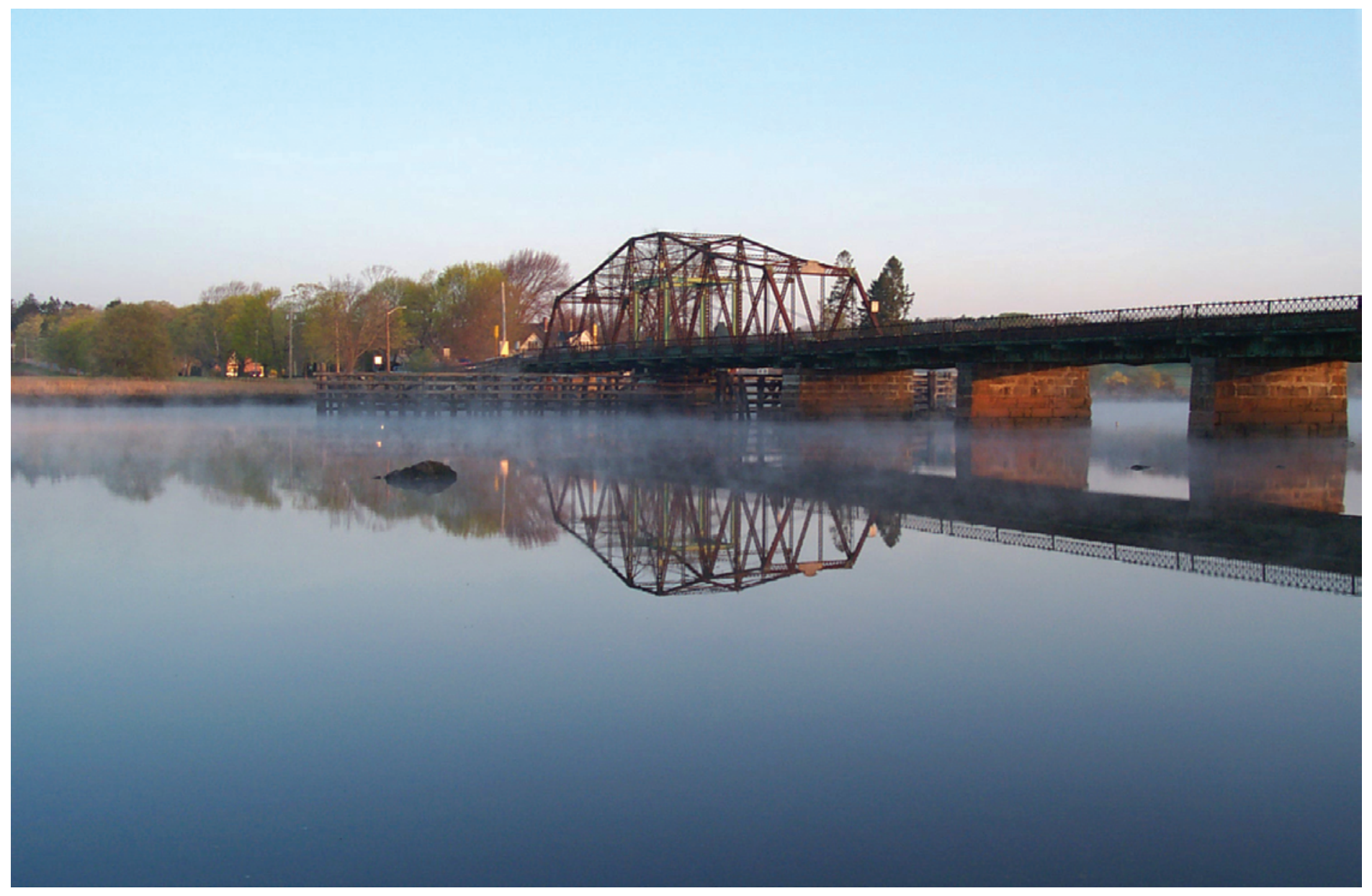

Scientific Investigations Report 2012-5277 
Front cover photograph: Berkley Bridge on the Taunton River. Constructed in 1896, this bridge was replaced by a new structure in 2010. Back cover photographs: Collage of Taunton River Basin scenes. 


\section{Nutrient and Sediment Concentrations, Yields, and Loads in Impaired Streams and Rivers in the Taunton River Basin, Massachusetts, 1997-2008}

By Jeffrey R. Barbaro and Jason R. Sorenson

Prepared in cooperation with the

Massachusetts Department of Environmental Protection,

Division of Watershed Management

Scientific Investigations Report 2012-5277 


\section{U.S. Department of the Interior \\ KEN SALAZAR, Secretary \\ U.S. Geological Survey \\ Marcia K. McNutt, Director}

U.S. Geological Survey, Reston, Virginia: 2013

For more information on the USGS — the Federal source for science about the Earth, its natural and living resources, natural hazards, and the environment, visit http://www.usgs.gov or call 1-888-ASK-USGS.

For an overview of USGS information products, including maps, imagery, and publications, visit http://www.usgs.gov/pubprod

To order this and other USGS information products, visit http://store.usgs.gov

Any use of trade, firm, or product names is for descriptive purposes only and does not imply endorsement by the U.S. Government.

Although this information product, for the most part, is in the public domain, it also may contain copyrighted materials as noted in the text. Permission to reproduce copyrighted items must be secured from the copyright owner.

Suggested citation:

Barbaro, J.R., and Sorenson, J.R., 2013, Nutrient and sediment concentrations, yields, and loads in impaired streams and rivers in the Taunton River Basin, Massachusetts, 1997-2008: U.S. Geological Survey Scientific Investigations Report 2012-5277, 89 p., at http://pubs.usgs.gov/sir/2012/5277/. 


\section{Acknowledgments}

The authors gratefully acknowledge the assistance of Thomas Ransley and the late Guy Ransley of Shaw's Boat Yard, Mr. Ronald Medeiros of Raynham, Mass., and many other town and State employees who provided information on water use and infrastructure over the course of this study. The authors also thank Kim McCoy and Dr. Kevin Curry of Bridgewater State College and Gary Gonyea, Richard Chase, Brian Friedman and Steve Daukas of the Massachusetts Department of Environmental Protection for providing data used in this study. Andy Waite of the U.S. Geological Survey (USGS) provided assistance in the field, and Northeastern University co-op students Larissa Cupp, Andrew Spiers, Meredith Borenstein, and Andrew Ingalls, and USGS Volunteer for Science Zachary Mason provided assistance in the office and field. USGS colleague reviews were conducted by Leslie DeSimone, Greg Koltun, and Andrew Ebner. The authors also acknowledge the technical assistance of Phil Zarriello and Chris Waldron of the USGS. 
THIS PAGE INTENTIONALLY LEFT BLANK 


\section{Contents}

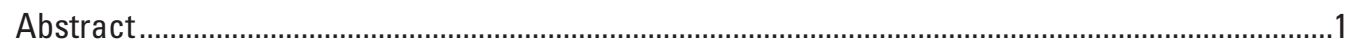

Introduction

Purpose and Scope ......................................................................................................

Previous Investigations................................................................................................. 4

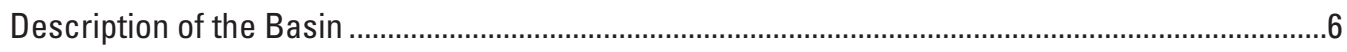

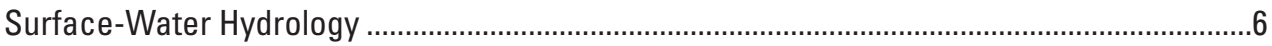

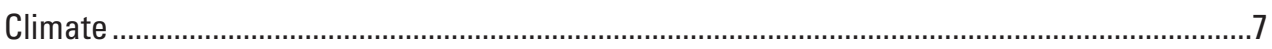

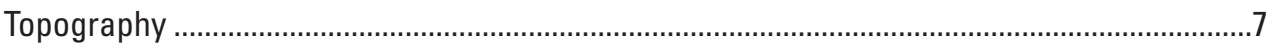

Land Use and Land Cover....................................................................................................

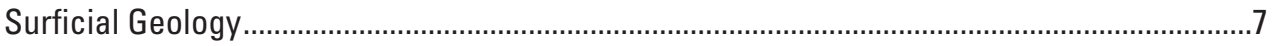

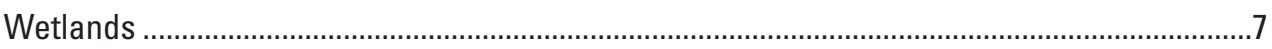

Water Withdrawals and Wastewater-Return Flows...............................................................

Precipitation-Runoff Model of the Taunton River Basin.............................................................11

Description of Water-Quality and Streamflow Data Collection and Management .........................12

Compilation of Previously Collected Water-Quality Data ........................................................12

2008 U.S. Geological Survey Water-Quality and Streamflow Data Collection ........................16

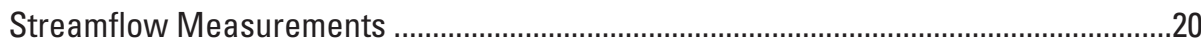

Continuous Field Parameter Data Collection .................................................................20

Water-Quality Sample Collection ...................................................................................23

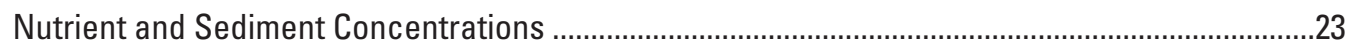

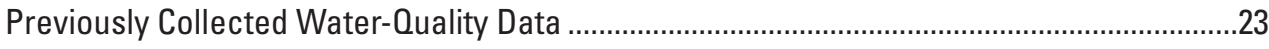

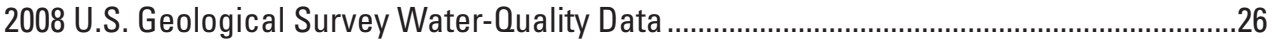

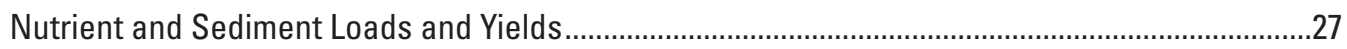

Loads Calculated from Previously Collected Water-Quality Data ...........................................27

Loads from 2008 U.S. Geological Survey Water-Quality Data ...................................................27

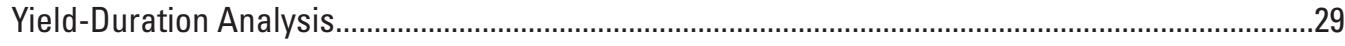

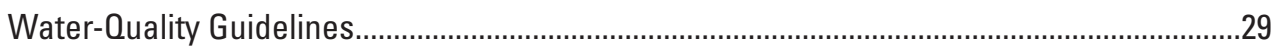

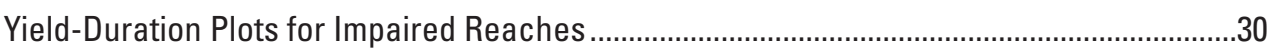

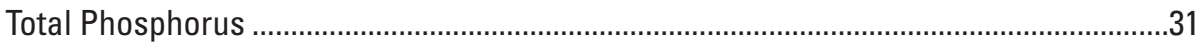

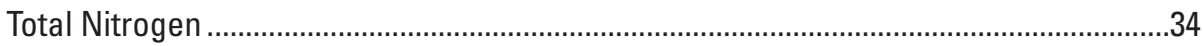

Total Suspended Solids......................................................................................................

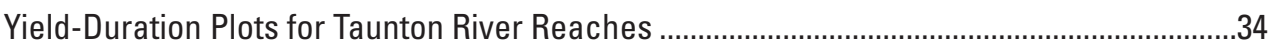

SPARROW-Predicted Sources of Total Nitrogen and Phosphorus Loads .......................................35

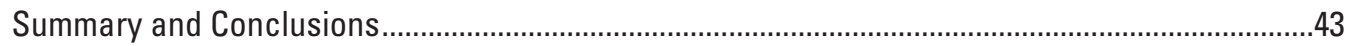

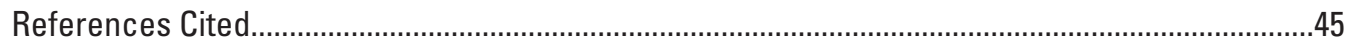

Appendix 1. Development and Calibration of the Hydrological Simulation Program-FORTRAN

(HSPF) Precipitation-Runoff Model of the Taunton River Basin ..............................................55

Appendix 2. Water-Quality Data 


\section{Figures}

1. Map showing location of Taunton River Basin, Massachusetts Department of Environmental Protection (MA DEP) impaired reaches, 2008 U.S. Geological Survey (USGS) sampling sites, municipal wastewater-treatment plants in the impaired-reach areas, and climate stations, Massachusetts.

2. Map showing generalized 1999 land use in the Taunton River Basin, Massachusetts.

3. Map showing generalized surficial geology in the Taunton River Basin, Massachusetts.

4. Map showing wetlands in the Taunton River Basin, Massachusetts.

5. Map showing water-quality sampling sites and Hydrological Simulation ProgramFORTRAN (HSPF) subbasins in the Taunton River Basin, Massachusetts .13

6. Maps showing water-quality sampling sites, Hydrological Simulation ProgramFORTRAN (HSPF) model reaches, and impaired reaches in drainage areas to $A$, the Matfield River, $B$, the Rumford River, and $C$, Segreganset River and unnamed tributary to Cedar Swamp River, Taunton River Basin, Massachusetts.

7. Graphs showing total phosphorus yield-duration plots for impaired reaches A, MA62-06 (lower Salisbury Plain River); B, MA62-32 (upper Matfield River); C, MA62-32 (lower Matfield River); D, MA62-05 (upper Salisbury Plain River); E, MA62-07 (Trout Brook); F, MA62-08 (Salisbury Brook); G, MA62-09 (Beaver Brook); H, MA62-38 (Meadow Brook); I, MA62-33 (Shumatuscacant River); J, MA32-39 (Rumford River); and K, MA62-53/54 (Segreganset River) in the Taunton River Basin ...32

8. Graphs showing total nitrogen yield-duration plots for impaired reaches $A$, MA62-06 (lower Salisbury Plain River); B, MA62-32 (upper Matfield River); C, MA62-32 (lower Matfield River); D, MA62-05 (upper Salisbury Plain River); E, MA62-07 (Trout Brook); F, MA62-08 (Salisbury Brook); G, MA62-09 (Beaver Brook); H, MA62-38 (Meadow Brook); I, MA32-39 (Rumford River); and J, MA62-53/54 (Segreganset River) in the Taunton River Basin.

9. Graphs showing total suspended solids yield-duration plots for impaired reaches A, MA62-06 (lower Salisbury Plain River); B, MA62-32 (upper Matfield River); C, MA62-32 (lower Matfield River); D, MA62-05 (upper Salisbury Plain River); E, MA62-07 (Trout Brook); F, MA62-08 (Salisbury Brook); G, MA62-09 (Beaver Brook); H, MA62-38 (Meadow Brook); I, MA62-33 (Shumatuscacant River); and J, MA32-39 (Rumford River) in the Taunton River Basin

10. Graphs showing yield-duration plots for water-quality sampling sites on the Taunton River at the U.S. Geological Survey (USGS) streamgage at Titicut Street (station no. 01108000), Bridgewater, and near the Berkley Bridge, Dighton/Berkley line for $A$, total phosphorus, and $B$, total nitrogen, Taunton River Basin 


\section{Tables}

1. Impaired reaches identified by the Massachusetts Department of Environmental Protection in the Taunton River Basin, Massachusetts..................................................

2. Water-quality sampling sites in the Taunton River Basin, Massachusetts. .....................14

3. Locational information and summary of water-quality data, 1997-2006, for sampling sites in the impaired-reach areas and on the Taunton River at Titicut Street, East Bridgewater, Taunton River Basin, Massachusetts.

4. Water-quality and streamflow data for sampling events conducted in 2008 at sites on the Matfield River at the U.S. Geological Survey streamgage at Elmwood, East Bridgewater, and the Taunton River near the Berkley Bridge, Dighton/Berkley line, Taunton River Basin, Massachusetts.

5. Comparison between gaged daily mean streamflow and measured instantaneous streamflow at the water-quality sampling site on the Taunton River near the Berkley Street bridge, Dighton/Berkley line, Taunton River Basin, Massachusetts.

6. Median nutrient and total suspended solids concentrations in impaired reaches and land use in drainage areas to impaired reaches in the Taunton River Basin, Massachusetts.

7. Total nitrogen and total phosphorus concentrations in U.S. Geological Survey reference streams in New Hampshire and eastern Massachusetts, and U.S. Environmental Protection Agency subecoregion 59 streams

8. Summary of daily loads, 1997-2006, for sampling sites in the impaired-reach areas and on the Taunton River at Titicut Street, East Bridgewater, Taunton River Basin, Massachusetts.

9. Daily loads for sampling events conducted in $\mathbf{2 0 0 8}$ at sites on the Matfield River at the U.S. Geological Survey streamgage at Elmwood, East Bridgewater, and the Taunton River near the Berkley Bridge, Dighton/Berkley line, Taunton River Basin, Massachusetts.

10. SPARROW model predictions of mean annual total phosporus and total nitrogen loads from sources in total drainage areas to impaired reaches and the Taunton River, Taunton River Basin, Massachusetts. 


\section{Conversion Factors, Datum, and Abbreviations}

Inch/Pound to SI

\begin{tabular}{|c|c|c|}
\hline Multiply & By & To obtain \\
\hline \multicolumn{3}{|c|}{ Length } \\
\hline inch (in.) & 2.54 & centimeter $(\mathrm{cm})$ \\
\hline inch (in.) & 25.4 & millimeter $(\mathrm{mm})$ \\
\hline foot (ft) & 0.3048 & meter $(\mathrm{m})$ \\
\hline mile (mi) & 1.609 & kilometer $(\mathrm{km})$ \\
\hline \multicolumn{3}{|c|}{ Area } \\
\hline acre & 4,047 & square meter $\left(\mathrm{m}^{2}\right)$ \\
\hline acre & 0.004047 & square kilometer $\left(\mathrm{km}^{2}\right)$ \\
\hline square mile $\left(\mathrm{mi}^{2}\right)$ & 2.590 & square kilometer $\left(\mathrm{km}^{2}\right)$ \\
\hline \multicolumn{3}{|c|}{ Volume } \\
\hline gallon (gal) & 3.785 & liter (L) \\
\hline gallon (gal) & 0.003785 & cubic meter $\left(\mathrm{m}^{3}\right)$ \\
\hline million gallons (Mgal) & 3,785 & cubic meter $\left(\mathrm{m}^{3}\right)$ \\
\hline cubic foot $\left(\mathrm{ft}^{3}\right)$ & 0.02832 & cubic meter $\left(\mathrm{m}^{3}\right)$ \\
\hline \multicolumn{3}{|c|}{ Flow rate } \\
\hline foot per second & 0.3048 & meter per second $(\mathrm{m} / \mathrm{s})$ \\
\hline cubic foot per second $\left(\mathrm{ft}^{3} / \mathrm{s}\right)$ & 0.02832 & cubic meter per second $\left(\mathrm{m}^{3} / \mathrm{s}\right)$ \\
\hline million gallons per day (Mgal/d) & 0.04381 & cubic meter per second $\left(\mathrm{m}^{3} / \mathrm{s}\right)$ \\
\hline inch per year (in/yr) & 25.4 & millimeter per year $(\mathrm{mm} / \mathrm{yr})$ \\
\hline \multicolumn{3}{|c|}{ Mass } \\
\hline pound per square mile per day $\left(\mathrm{lb} / \mathrm{mi}^{2} / \mathrm{d}\right)$ & 0.00176 & kilogram per hectare per day $(\mathrm{kg} / \mathrm{ha} / \mathrm{d})$ \\
\hline ton per year & 1.102 & metric ton per year \\
\hline \multicolumn{3}{|c|}{ Transmissivity* } \\
\hline foot squared per day $\left(\mathrm{ft}^{2} / \mathrm{d}\right)$ & 0.09290 & meter squared per day $\left(\mathrm{m}^{2} / \mathrm{d}\right)$ \\
\hline
\end{tabular}

Temperature in degrees Celsius $\left({ }^{\circ} \mathrm{C}\right)$ may be converted to degrees Fahrenheit ( $\left.{ }^{\circ} \mathrm{F}\right)$ as follows:

$$
{ }^{\circ} \mathrm{F}=\left(1.8 \mathrm{x}^{\circ} \mathrm{C}\right)+32
$$

Temperature in degrees Fahrenheit $\left({ }^{\circ} \mathrm{F}\right)$ may be converted to degrees Celsius $\left({ }^{\circ} \mathrm{C}\right)$ as follows:

$$
{ }^{\circ} \mathrm{C}=\left({ }^{\circ} \mathrm{F}-32\right) / 1.8
$$

Vertical coordinate information is referenced to the North American Vertical Datum of 1988 (NAVD 88).

Horizontal coordinate information is referenced to the North American Datum of 1983 (NAD 83).

Altitude, as used in this report, refers to distance above the vertical datum.

*Transmissivity: The standard unit for transmissivity is cubic foot per day per square foot times foot of aquifer thickness [ $\left.\left[\mathrm{ft}^{3} / \mathrm{d}\right) / \mathrm{ft}^{2}\right] \mathrm{ft}$. In this report, the mathematically reduced form, foot squared per day $\left(\mathrm{ft}^{2} / \mathrm{d}\right)$, is used for convenience.

Specific conductance is given in microsiemens per centimeter at 25 degrees Celsius $(\mu \mathrm{S} / \mathrm{cm}$ at $\left.25^{\circ} \mathrm{C}\right)$.

Concentrations of chemical constituents in water are given either in milligrams per liter (mg/L) or micrograms per liter $(\mu \mathrm{g} / \mathrm{L})$. 


\section{Abbreviations}

$\begin{array}{ll}\text { AWRF } & \text { Advanced Water Reclamation Facility } \\ \text { BSC } & \text { Bridgewater State College } \\ \text { EPA } & \text { U.S. Environmental Protection Agency } \\ \text { EWI } & \text { Equal width increment } \\ \text { HSPF } & \text { Hydrologic Simulation Program-FORTRAN } \\ \text { LULC } & \text { Land Use Land Cover } \\ \text { MassGIS } & \text { Massachusetts Geographic Information System } \\ \text { MA DEP } & \text { Massachusetts Department of Environmental Protection } \\ \text { MEP } & \text { Massachusetts Estuaries Project } \\ \text { NAWOA } & \text { National Water Quality Assessment Program } \\ \text { SSC } & \text { Suspended sediment concentration } \\ \text { TSS } & \text { Total suspended solids } \\ \text { USGS } & \text { U.S. Geological Survey }\end{array}$


THIS PAGE INTENTIONALLY LEFT BLANK 


\title{
Nutrient and Sediment Concentrations, Yields, and Loads in Impaired Streams and Rivers in the Taunton River Basin, Massachusetts, 1997-2008
}

\author{
By Jeffrey R. Barbaro and Jason R. Sorenson
}

\section{Abstract}

Rapid development, population growth, and the changes in land and water use accompanying development are placing increasing stress on water resources in the Taunton River Basin. An assessment by the Massachusetts Department of Environmental Protection determined that a number of tributary streams to the Taunton River are impaired for a variety of beneficial uses because of nutrient enrichment. Most of the impaired reaches are in the Matfield River drainage area in the vicinity of the City of Brockton. In addition to impairments of stream reaches in the basin, discharge of nutrient-rich water from the Taunton River contributes to eutrophication of Mount Hope and Narragansett Bays. To assess water quality and loading in the impaired tributary stream reaches in the basin, the U.S. Geological Survey, in cooperation with the Massachusetts Department of Environmental Protection compiled existing water-quality data from previous studies for the period 1997-2006, developed and calibrated a Hydrological Simulation Program-FORTRAN (HSPF) precipitation-runoff model to simulate streamflow in areas of the basin that contain the impaired reaches for the same time period, and collected additional streamflow and water-quality data from sites on the Matfield and Taunton Rivers in 2008. A majority of the waterquality samples used in the study were collected between 1999 and 2006. Overall, the concentration, yield, and load data presented in this report represent water-quality conditions in the basin for the period 1997-2008.

Water-quality data from 52 unique sites were used in the study. Most of the samples from previous studies were collected between June and September under dry weather conditions. Simulated or measured daily mean streamflow and water-quality data were used to estimate constituent yields and loads in the impaired tributary stream reaches and the main stem of the Taunton River and to develop yield-duration plots for reaches with sufficient water-quality data. Total phosphorus concentrations in the impaired-reach areas ranged from 0.0046 to 0.91 milligrams per liter $(\mathrm{mg} / \mathrm{L})$ in individual samples (number of samples $(n)=331$ ), with a median of $0.090 \mathrm{mg} / \mathrm{L}$; total nitrogen concentrations ranged from 0.34 to $14 \mathrm{mg} / \mathrm{L}$ in individual samples $(\mathrm{n}=139)$, with a median of
$1.35 \mathrm{mg} / \mathrm{L}$; and total suspended solids concentrations ranged from $<1$ to $69 \mathrm{mg} / \mathrm{L}$ in individual samples $(\mathrm{n}=155)$, with a median of $5.3 \mathrm{mg} / \mathrm{L}$. Concentrations of total phosphorus and total nitrogen in most of the samples collected from the impaired-reach areas were higher than various nutrient guidelines for reference streams in the northeast. Among the impaired reaches, median total phosphorus concentrations ranged from $0.016 \mathrm{mg} / \mathrm{L}$ in the Rumford River (impaired reach MA62-39) to $0.22 \mathrm{mg} / \mathrm{L}$ in the lower part of the Salisbury Plain River (MA62-06); median total nitrogen concentrations ranged from $0.61 \mathrm{mg} / \mathrm{L}$ in the Rumford River (MA62-39) to $6.2 \mathrm{mg} / \mathrm{L}$ in the lower Salisbury Plain River (MA62-06), and median total suspended solids concentrations ranged from $2 \mathrm{mg} / \mathrm{L}$ in the Rumford River (MA62-39) to $8 \mathrm{mg} / \mathrm{L}$ in Trout Brook (MA62-07). Median concentrations of nutrients were highest in the lower Salisbury Plain and Matfield Rivers, the reaches downstream from the Brockton Advanced Water Reclamation Facility outfall. High concentrations indicate that the outfall was a major point source for nutrients for the period 1999-2006 when these data were collected. In the remaining impaired reaches affected only by diffuse (nonpoint) sources, median concentrations were substantially lower than in reaches downstream from the outfall, and generally increased with the percentage of developed land in the drainage area to the reach. A Spearman rho rank correlation test was used to evaluate relations between median concentration and the percentage of developed land in the drainage area to the reach. Correlation coefficients for reaches affected by diffuse sources only were $0.667(\mathrm{p}=0.07)$ for total phosphorus $(\mathrm{n}=8)$, and $0.750(\mathrm{p}=0.05)$ for both total nitrogen and total suspended solids $(\mathrm{n}=7)$.

Yield-duration plots also were used to compare measured daily yields to threshold-yield curves. Threshold-yield curves are developed using water-quality guidelines, which are defined as allowable or threshold concentrations expected to limit eutrophication in streams, for a wide range in flows. Results showed that measured total phosphorus yields in the impaired reaches typically were greater than threshold yields based on the 75 th percentile total phosphorus concentration $(0.021 \mathrm{mg} / \mathrm{L})$ in two minimally affected U.S. Geological Survey reference streams in New England, but less than threshold yields based on a commonly used 1986 U.S. 
Environmental Protection Agency water-quality criterion concentration $(0.1 \mathrm{mg} / \mathrm{L})$. Measured total nitrogen yields in the impaired reaches typically were greater than threshold yields based on the 75th percentile total nitrogen concentration $(0.48 \mathrm{mg} / \mathrm{L})$ in the minimally affected reference streams and the 25 th percentile concentration $(0.57 \mathrm{mg} / \mathrm{L})$ for U.S. Environmental Protection Agency subecoregion 59 streams. Measured total suspended solids yields in the impaired reaches typically were greater than threshold yields based on a tenfold dilution of the Brockton Advanced Water Reclamation Facility winter daily maximum effluent limit of $30 \mathrm{mg} / \mathrm{L}$ ( $3 \mathrm{mg} / \mathrm{L})$, but considerably less than an informal Massachusetts Department of Environmental Protection guideline ( $80 \mathrm{mg} / \mathrm{L}$ ). Similar to concentrations, the highest total phosphorus and total nitrogen yields were observed in the reaches downstream from the Brockton Advanced Water Reclamation Facility outfall (lower Salisbury Plain River, MA62-06; and upper and lower Matfield River, MA62-32). Yields for lower flows were up to 7 pounds/square mile/day $\left(\mathrm{lb} / \mathrm{mi}^{2} / \mathrm{d}\right)$ for total phosphorus and $100 \mathrm{lb} / \mathrm{mi}^{2} / \mathrm{d}$ for total nitrogen in these reaches. In most of the impaired reaches not affected by the Brockton Advanced Water Reclamation Facility outfall, yields were lower than in reaches downstream from the outfall, and the difference between measured and threshold yields was fairly uniform over a wide range of flows, suggesting that multiple processes contribute to nonpoint loading in these reaches.

The Northeast and Mid-Atlantic SPAtially-Referenced Regression On Watershed (SPARROW) models for total phosphorus and total nitrogen also were used to estimate annual nutrient loads in the impaired tributary stream reaches and main stem of the Taunton River and predict the distribution of these loads among point and diffuse sources in reach drainage areas. SPARROW is a regional, statistical model that relates nutrient loads in streams to upstream sources and land-use characteristics and can be used to make predictions for streams that do not have nutrient-load data. The model predicts mean annual loads based on longterm streamflow and water-quality data and nutrient source conditions for the year 2002. Predicted mean annual nutrient loads from the SPARROW models were consistent with the measured yield and load data from sampling sites in the basin. For conditions in 2002, the Brockton Advanced Water Reclamation Facility outfall accounted for over 75 percent of the total nitrogen load and over 93 percent of the total phosphorus load in the Salisbury Plain and Matfield Rivers downstream from the outfall. Municipal point sources also accounted for most of the load in the main stem of the Taunton River. Multiple municipal wastewater discharges in the basin accounted for about 76 and 46 percent of the delivered loads of total phosphorus and total nitrogen, respectively, to Mount Hope Bay. For similarly sized watersheds, total delivered loads were lower in watersheds without point sources compared to those with point sources, and sources associated with developed land accounted for most of the delivered phosphorus and nitrogen loads to the impaired reaches.
The concentration, yield, and load data evaluated in this study may not be representative of current (2012) point-source loading in the basin; in particular, most of the water-quality data used in the study (1999-2006) were collected prior to completion of upgrades to the Brockton Advanced Water Reclamation Facility that reduced total phosphorus and nitrogen concentrations in treated effluent. Effluent concentration data indicate that, for a given flow rate, effluent loads of total phosphorus and total nitrogen declined by about 80 and 30 percent, respectively, between the late 1990s and 2008 in response to plant upgrades. Consequently, current (2012) water-quality conditions in the impaired reaches downstream from the facility likely have improved compared to conditions described in the report.

\section{Introduction}

The 533 square miles $\left(\mathrm{mi}^{2}\right)$ Taunton River Basin in southeastern Massachusetts (fig. 1) is undergoing rapid development and population growth. The changes in land and water use accompanying development are placing increasing stress on water resources in the basin. In particular, excessive loads of nutrients and other constituents from point and diffuse (nonpoint) sources have adversely affected aquatic habitat, water quality, and the recreational value of streams in parts of the basin. An assessment by the Massachusetts Department of Environmental Protection (MA DEP) determined that a number of tributary streams to the Taunton River are impaired for a variety of beneficial uses under section 303(d) of the Clean Water Act (CWA) (Massachusetts Department of Environmental Protection, 2005, 2006a). Other stream reaches in the basin were assessed and found to support designated uses, whereas, other streams were not assessed by the MA DEP. Identified impairments include nutrient enrichment (low dissolved oxygen and excessive algal and invasive plant growth), fecal coliforms, dioxins and pesticides, mercury, and sedimentation (Massachusetts Department of Environmental Protection, 2005, 2006a). Nutrients (total phosphorus and total nitrogen) and sediment are the constituents of concern in the impaired reaches. In addition to impairments in stream reaches within the basin, discharge of nutrient-rich water from the Taunton River to Mount Hope Bay contributes to eutrophication of Mount Hope and Narragansett Bays. Observed effects of eutrophication in Mount Hope Bay include reductions in water clarity and dissolved oxygen concentrations, degradation of critical habitats such as eelgrass beds, replacement of sensitive benthic species with those more tolerant to low-oxygen conditions, reductions in the productivity of finfish and shellfish, and fish kills (Rhode Island Department of Environmental Management, 2003).

To restore impaired reaches, reductions in constituent concentrations and loads are typically required. However, to establish appropriate and achievable reductions, the magnitude of nutrient and sediment loads relative to allowable loads 


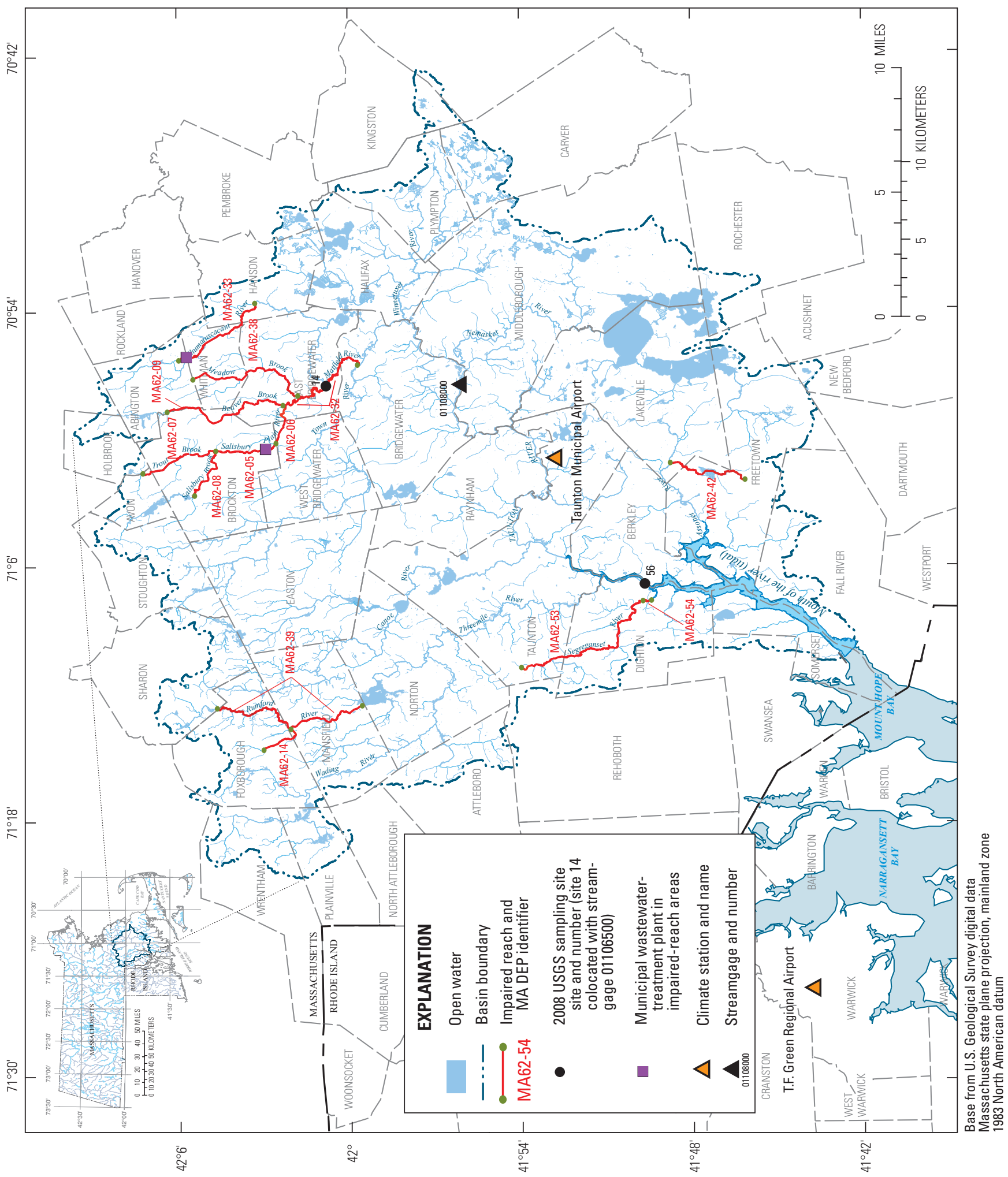


needs to be determined. In addition, constituent sources in the drainage areas to impaired reaches need to be identified and quantified to the extent possible. Water quality in the basin is affected by complex interactions between land use and land cover, water use, streamflow, and groundwater flow. In the Taunton River Basin, tidal mixing of saline and freshwater in the Taunton River complicates the assessment of nutrient loading to Mount Hope Bay. The pattern of developed land use and water use (specifically locations of major water withdrawals and municipal wastewater return flows) affects the relative magnitudes of point and diffuse constituent sources and the resulting constituent loading in the impaired reaches in the basin. In this study, the 13 stream reaches impaired for designated uses (table 1; fig. 1) were investigated by combining water-quality data with hydrologic modeling. Most of these reaches are in the Matfield River drainage basin, around the City of Brockton.

To assess water quality and loading in the impaired reaches of the basin, the U.S. Geological Survey (USGS), in cooperation with MA DEP, (1) compiled existing water-quality data from previous studies in the basin, (2) developed and calibrated a Hydrological Simulation Program-FORTRAN (HSPF) precipitation-runoff model (Bicknell and others, 2000) for streamflow for the areas of the basin that contain the 13 impaired stream reaches, and (3) collected additional streamflow and water-quality data from sites on the Matfield and Taunton Rivers (fig. 1). The model and water-quality data were used to estimate constituent loads in the impaired tributary stream reaches and Taunton River using existing and new water-quality data and to develop yield-duration plots for all reaches with sufficient water-quality data. Nutrient loads from the main stem of the Taunton River to Mount Hope Bay also were evaluated as part of this study. The Northeast and Mid-Atlantic SPAtially-Referenced Regression On Watershed attributes (SPARROW) models for total phosphorus and total nitrogen (Moore and others, 2011) were used to calculate mean annual nutrient loads for the impaired reaches and the Taunton River and predict the distribution of these loads among point and diffuse sources in the drainage areas to these reaches for 2002 source conditions. This information is intended to assist MA DEP with the development of nutrient and sediment Total Maximum Daily Loads (TMDLs) for impaired tributary stream reaches in the basin, provide a basis for the distribution of nutrient and sediment load reductions, and support possible future studies of eutrophication in Mount Hope and Narragansett Bays.

\section{Purpose and Scope}

The report describes the compilation of water-quality data collected during previous studies in the basin, the acceptance criteria used to evaluate these data, and the methods and results of additional streamflow and water-quality data collection conducted by the USGS in 2008 at two sites on the Matfield and Taunton Rivers. USGS data collection included continuous monitoring of basic water-quality parameters for a 6-month period and collection of several streamflow measurements and flow-proportional water-quality samples between May and December of 2008. Sample collection at the Taunton River site involved synchronizing data collection with slack water during low tide to obtain an estimate of freshwater loading from upstream sources.

The development and calibration of an HSPF precipitation-runoff model is described in appendix 1. Although the precipitation-runoff model was calibrated for simulation of streamflow only in drainage areas to the 13 impaired tributary stream reaches, the model was set up to facilitate possible future simulation of streamflow and water quality in the entire basin. Information on the climate, topography, surficial geology, land use, and hydrology of the entire basin was obtained and formatted to develop the HSPF model. Information on water use (municipal, agricultural, and residential water withdrawals and municipal wastewater return flows) in the drainage areas to the impaired reaches also was obtained and compiled for the 10-year model calibration period (19972006). Simulated daily mean streamflow was used to estimate loads and construct nutrient and sediment-yield-duration plots for water-quality sampling sites in the impaired reaches. Plots included threshold-yield curves calculated using selected water-quality guidelines and measured yields estimated from water-quality samples. Most (about 95 percent) of the waterquality data used to estimate daily loads and yields consisted of instantaneous measurements from grab or cross-sectional composite samples.

The Northeast and Mid-Atlantic SPARROW models also were used to predict mean annual nutrient loads for impaired reaches and the Taunton River, and to determine the distribution of these loads among point and diffuse sources in the basin for 2002 source conditions.

\section{Previous Investigations}

Water resources in the Taunton River Basin have been studied extensively over the past several decades by State and Federal agencies and other organizations. Previous investigations were conducted to determine water quality in streams within the basin and estimate loads delivered to Mount Hope Bay from the Taunton River. Hydrologic studies include those by Williams (1968), Williams and Willey (1973), Williams and others (1973), Frimpter (1973), Wandle and Keezer (1984), and Lapham (1988).

Two studies have been published on nutrient loads to Mount Hope Bay since the 1990s. Nixon and others (1995) reported that discharges of municipal wastewater and combined sewer overflows to the Taunton River are the most significant sources of nutrients to Mount Hope Bay. They estimated that the annual total nitrogen and total phosphorus loads from the Taunton River to Mount Hope Bay were about 3,100 and 350 metric tons per year, respectively, for the period 1982-89 and concluded that the Taunton River represented 


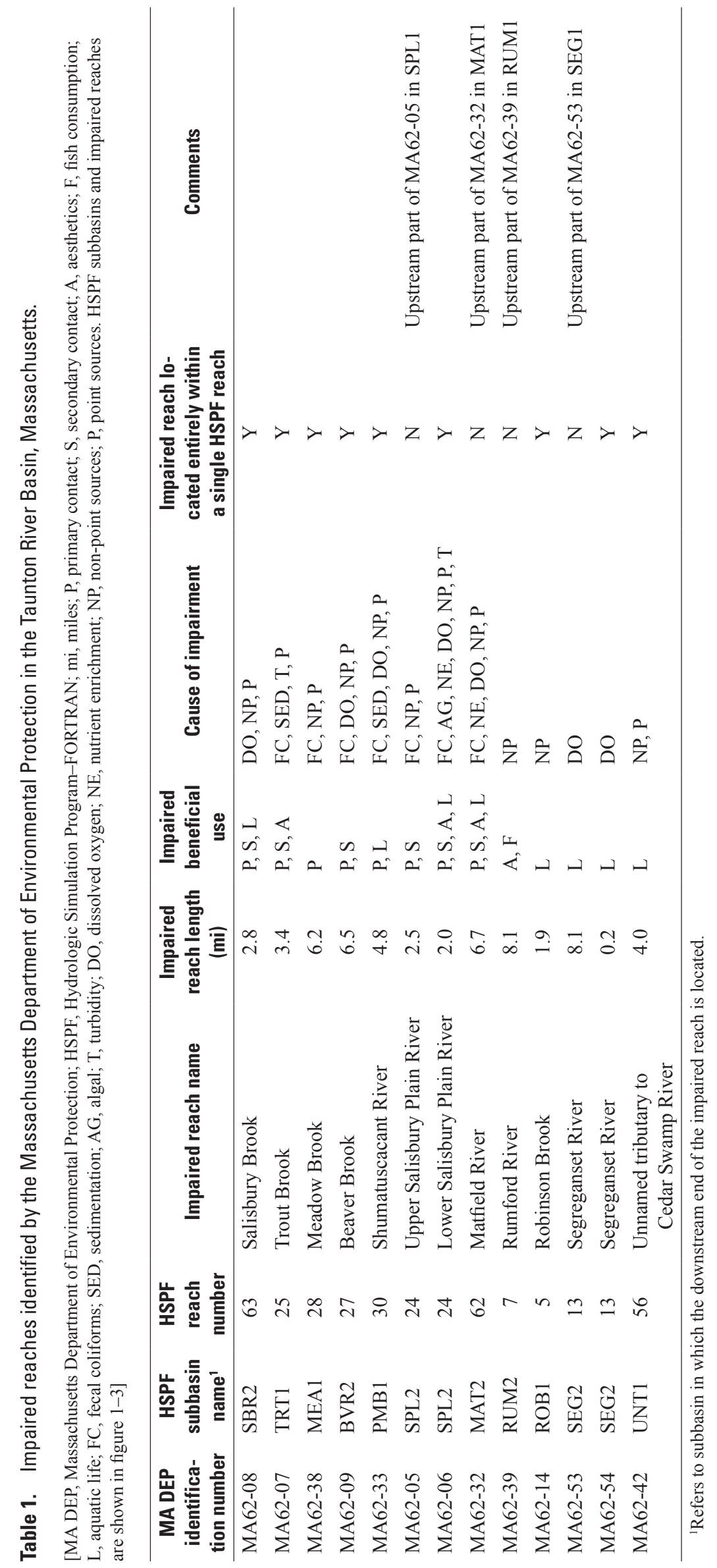


about 79 percent of the total annual nutrient load to Mount Hope Bay. Isaac (1997) estimated annual nutrient loads into Mount Hope Bay using two different approaches. A method based on water-quality data, referred to as the river method, resulted in an estimated total annual nitrogen load of about 1,296 metric tons per year. The second approach, based on land use, resulted in an annual nitrogen load of about 1,000 metric tons per year. Load estimates for the Taunton River included discharge from seven wastewater-treatment plants (WWTPs) in the Taunton River Basin including the larger facilities located in Brockton, Taunton, and Fall River (Isaac, 1997). These approaches indicated that point sources made up approximately 60 percent of the nitrogen load to Mount Hope Bay. Isaac (1997) also concluded that total phosphorus loading was dominated by point sources (75 percent of the total load), and that phosphorus may be retained in sediment at lower flows and washed out of channels at higher flows.

In addition to nutrient loading studies, several sampling programs have been conducted since the late 1990s to determine water quality in streams in the basin. Many samples from these programs were found to be appropriate for use in this study. The MA DEP collected samples in 1996, 2001, and 2006 as part of the Massachusetts Division of Watershed Management (DWM) monitoring program. Samples collected in 1996 were used to make a preliminary identification of stream reaches where one or more designated uses were impaired as a result of degraded aquatic habitat or water quality (Massachusetts Department of Environmental Protection, 2005). In 2001, 73 additional samples were collected from the Wading, Rumford, Canoe, Threemile, Satucket, and Assonet River subbasins and other locations to re-assess sampled reaches for pathogens, dissolved oxygen (DO), and organic enrichment; sample unassessed waterbodies; assist the U.S. Environmental Protection Agency (EPA) with WWTP compliance monitoring; and conduct a habitat assessment on the Satucket River and its tributaries (Massachusetts Department of Environmental Protection, 2005). Based on the sampling conducted by MA DEP in 1996 and 2001 and 131 samples collected by the ESS Group, Inc. (ESS) in 2002 (ESS Group, Incorporated, 2003), 13 stream reaches and numerous lakes and ponds in the basin were designated as impaired and placed on the EPA 303(d) list (Massachusetts Department of Environmental Protection, 2005, 2006a). An additional sampling program was conducted by the MA DEP in 2006. This program involved stream sampling at 24 locations, benthic macroinvertebrate monitoring and aquatic habitat assessments in 17 streams, and water column, aquatic sediment, and fish tissue toxicity testing at two lakes (Massachusetts Department of Environmental Protection, written commun., 2008). Samples also were collected for MA DEP by the ENSR Corporation (ENSR) in 2001 to determine in-stream copper criteria for three streams and WWTPs in the basin (ENSR Corporation, 2002). Samples were collected from 12 locations in the Nemasket, Threemile, Town, and Taunton Rivers.

A number of other sampling programs have been conducted since the late 1990s by groups other than MA DEP and their contractors. The USGS collected samples from the Wading, Matfield, Segreganset, and Taunton Rivers at partialrecord (that is, intermittent streamflow measurements) and continuous-record streamgages for various studies conducted between 1997 and 2004 (http://nwis.waterdata.usgs.gov/ma/ nwis/qwdata). The Watershed Access Laboratory (WAL) at Bridgewater State College (BSC) conducted several spring and summer sampling programs between 1999 and 2006 at 16 locations within the upper Taunton River watershed, primarily in the Matfield River watershed (Kevin Curry, Bridgewater State College, written commun., 2007). BSC results indicate that in 1999 and 2002 the Matfield River contributed 52 to 78 percent of the soluble reactive phosphorus load and 54 to 70 percent of the nitrate load, respectively, at the Taunton River at Titicut Street, Bridgewater streamgage (station no. 01108000). Finally, the Massachusetts Estuary Project (MEP) collected data in Mount Hope Bay and the lower Taunton River Basin in 2004 and 2006 (Howes and Samimy, 2006). Water-quality samples and field parameters were collected in early morning hours about every 2 weeks during slack water at low tide from eight freshwater locations in the basin, mostly near the mouth of the Taunton River. Grab samples were collected from multiple depths that varied as a function of total water depth at the time of sampling. The data from these programs used in this study are described in the Description of Water-Quality and Streamflow Data Collection and Management section of the report.

\section{Description of the Basin}

The Taunton River Basin is located in the southeastern portion of the Boston metropolitan area in southeastern Massachusetts (fig. 1). The basin contains all or part of 43 cities and towns, including the cities of Taunton, Attleboro, Brockton, and Fall River. The population of the basin was approximately 440,000 in 2000 (U.S. Census Bureau, 2011).

\section{Surface-Water Hydrology}

Surface-water drainage in the basin is generally to the south. Major tributaries to the Taunton River include the Threemile, Segreganset, Matfield, Canoe, Nemasket, Winnetuxet, and Town Rivers. The Taunton River flows into Mount Hope Bay, an embayment within Narragansett Bay, at Fall River, Mass. (fig. 1). Mount Hope Bay is considered a partially to well-mixed estuary (Goodrich, 1988; Pilson, 1985a; Nixon and others, 1995) with a tidal range of about 3 feet (ft) or less, and an estimated residence time between 14 and 49 days (Pilson, 1985a, b; Kincaid and others, 2003). The lower part of the Taunton River has a low gradient, and consequently, tidal inflows cause saline water to flow approximately 12 miles (mi) upstream from the mouth, and tidal backwater effects are observed as much as 22 mi upstream. Daily mean flow at the Taunton River at Titicut Street, Bridgewater 
streamgage (station no. 01108000), which is about $6 \mathrm{mi}$ upstream from the limit of tidal influence, averaged 495 cubic feet per second $\left(\mathrm{ft}^{3} / \mathrm{s}\right)$ over the past 60 years. Runoff from the Taunton River Basin composes about 30 percent of the freshwater inflow into Mount Hope Bay.

\section{Climate}

Precipitation for the period 1960-2006 averaged 45.1 inches per year (in/yr) (T.F. Green Regional Airport, Warwick, R.I., station no. 376698, fig. 1). Average monthly precipitation is fairly uniform throughout the year. At T.F. Green Airport, average long-term monthly precipitation ranged from 3.1 inches (in.) in July to 4.4 in. in March. The average annual air temperature for the period 1960-2006 was $50.9^{\circ} \mathrm{F}$. Average monthly temperatures for this period ranged from $26.8^{\circ} \mathrm{F}$ in January to $72.9^{\circ} \mathrm{F}$ in July. For the period 1935-61, Williams and others (1973) estimated the average yearly runoff from the basin to be 230 billion gallons per year $\left(975 \mathrm{ft}^{3} / \mathrm{s}\right)$, or about 57 percent of the annual precipitation for that period.

\section{Topography}

The basin is characterized by gently rolling topography and low relief. Altitudes range from about $450 \mathrm{ft}$ in the northwestern corner of the basin to sea level at the mouth of the Taunton River. The mean altitude of the basin is $105 \mathrm{ft}$. Lowlands often contain wetlands and cranberry bogs, which are concentrated in the western part of the basin. The Taunton River has one of the lowest gradients in the region, falling only about $26 \mathrm{ft}$ along its 40 -mi course.

\section{Land Use and Land Cover}

Data for land use and land cover (LULC) from the Massachusetts Office of Geographic Information (2008a) indicate that about 37 percent of the basin was forested in 1999 (fig. 2). An additional 26 percent of the basin was classified as residential land (including low-, medium, and high-density residential land), and approximately 4 percent of the basin was classified as combined commercial-industrial-transportation land. These developed areas (residential, commercial, industrial, and transportation) contain impervious surfaces that affect the hydrology and water quality of streams. Seven percent of the basin was classified as open, nonresidential land, and another 7 percent of the basin was classified as agricultural land use (including cranberry bogs). Wetlands composed 18 percent of the basin area, and about 5 percent of the basin was classified as open water, which includes ponds, reservoirs, and the channels of the larger rivers in the basin. The northeastern corner of the basin around the greater Brockton area is the most developed, whereas the eastern and southeastern parts of the basin contain the most undeveloped land and cranberry agriculture.
As described in greater detail in the HSPF model documentation section of this report (appendix 1), the LULC categories shown in figure 2 were consolidated from the 37-category State LULC data layer to develop the HSPF model.

\section{Surficial Geology}

The basin is characterized by upland hills consisting of drumlins, ground moraines composed of glacial till, and valleys consisting of glacial fluvial, lacustrine, and swamp deposits. Lapham (1988) identified 26 individual aquifers in the northern half of the basin that have transmissivity values that exceed $1,340 \mathrm{ft}^{2} / \mathrm{d}$. Although there are substantial aquifers that have been developed for water supplies, much of the basin is underlain by thick deposits of glacial till and lake-bottom sediments that are composed of fine sand interbedded with silt and clay (Lapham, 1988). Bedrock depths range from surface outcrops to about $200 \mathrm{ft}$ below surface in low-lying areas.

The MassGIS surficial geology data layer (Massachusetts Office of Geographic Information, 2008b) indicates that 44 percent of the basin is underlain by sand and gravel, and the remaining 56 percent of the basin is underlain by till and fine-grained stratified deposits (fig. 3). As described in greater detail in the HSPF model documentation section of the report (appendix 1), these categories were simplified from five types of geologic material in the surficial-geology data layer to develop the HSPF model.

\section{Wetlands}

The low-gradient Taunton River Basin contains extensive wetlands, including one of the largest wetlands and the largest peatland in the State, the 17,000-acre Hockomock Swamp in the towns of Bridgewater, Easton, Norton, Raynham, Taunton, and West Bridgewater. About 12.5 percent of the basin is covered by forested wetlands, and about 4.5 percent is covered by nonforested wetlands (fig. 4). In addition, this is an active cranberry growing region, with about 3,000 acres of cranberry bog identified in the MassGIS 1:5,000 scale wetlands data layer (Massachusetts Office of Geographic Information, 2008c). Open water accounts for another 4.5 percent of the basin area. Methods used to develop consolidated wetlands categories are described in greater detail in the HSPF model documentation section of the report (appendix 1).

\section{Water Withdrawals and Wastewater-Return Flows}

The Taunton River Basin has experienced rapid changes in land use, water use, and population in recent decades. For example, from 1990 to 2000 the towns of Berkley and Mansfield were among the fastest growing towns in the State with population increases of about 26 percent (Massachusetts State Data Center, 2011). Berkley and Mansfield saw additional 


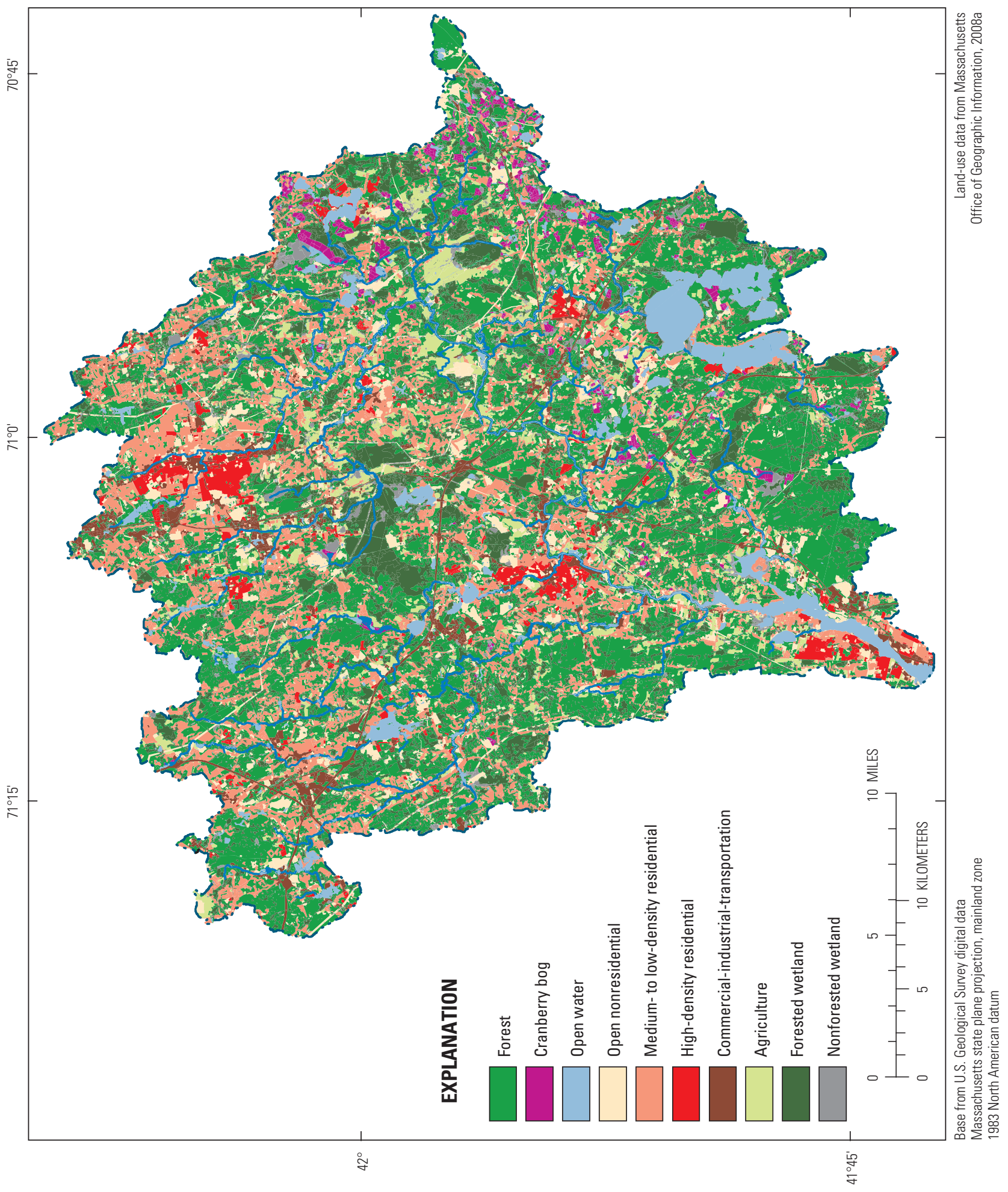

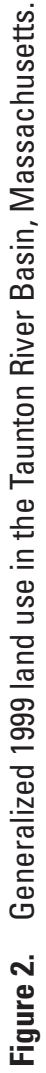




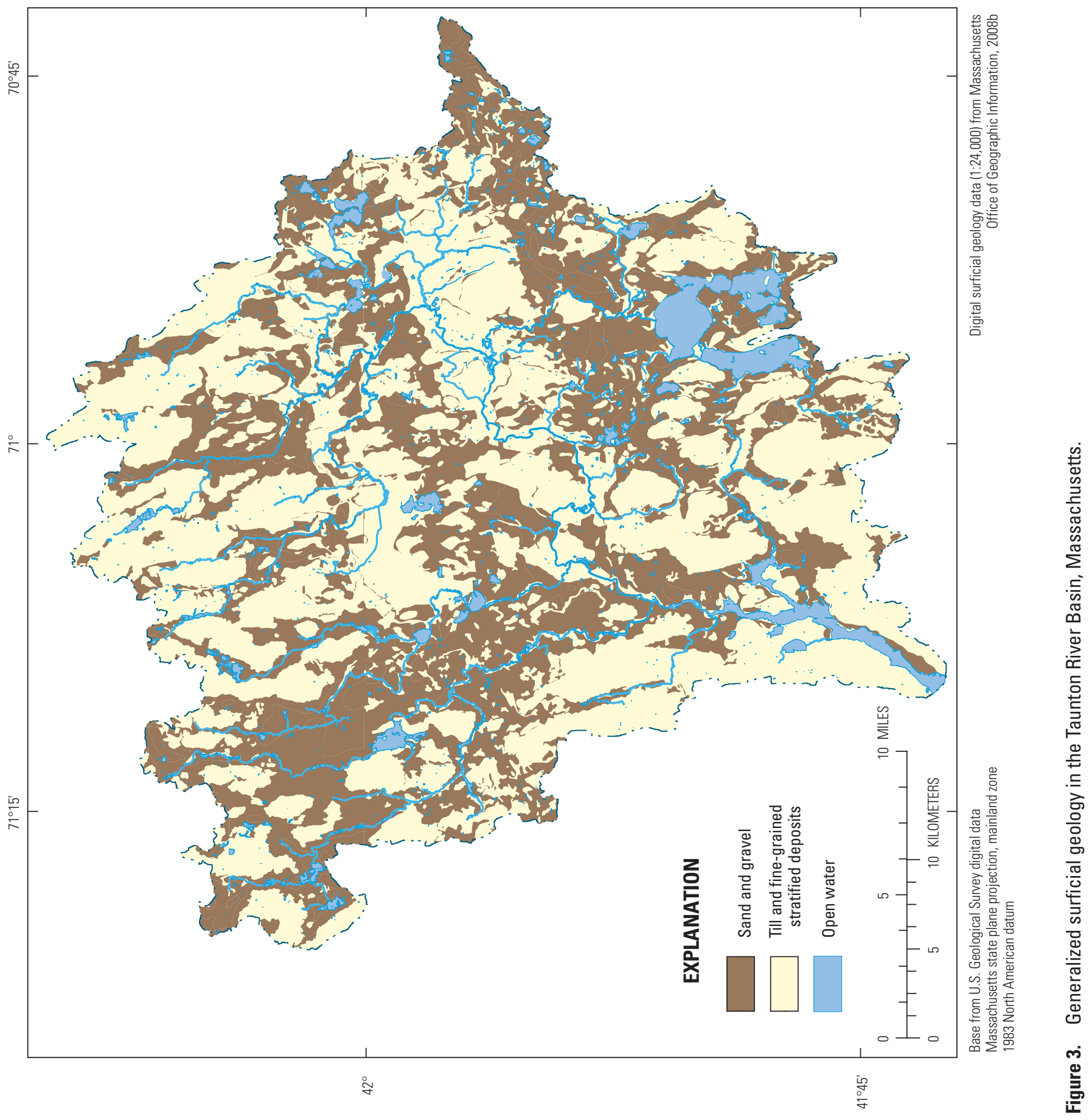




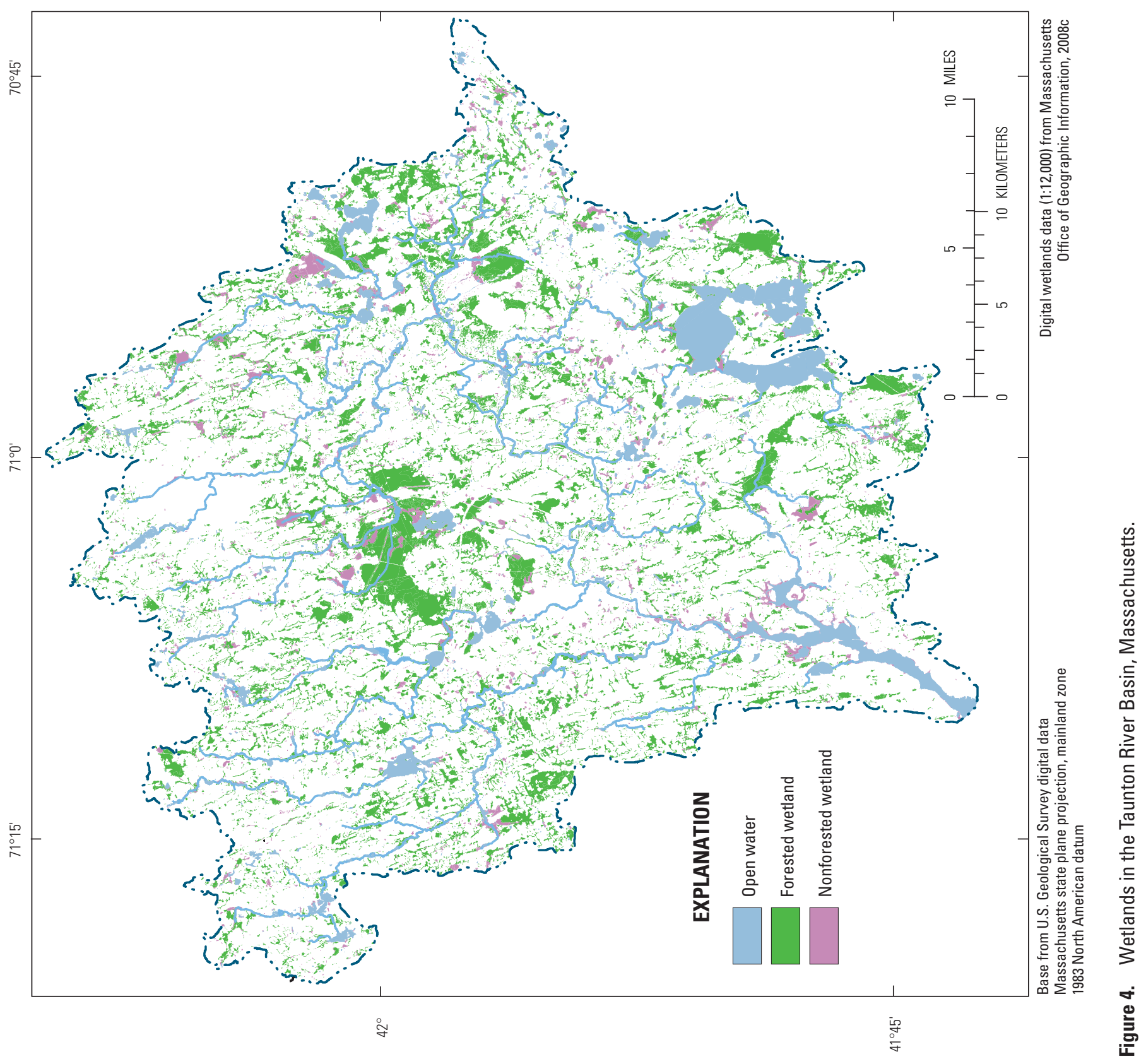


increases in population of 10.3 and 3.3 percent, respectively, between 2000 and 2010. Overall, the counties in the basin have experienced a median population growth of about 6.2 percent between 1990 and 2000, and 3.3 percent between 2000 and 2010. The increased water withdrawals and wastewater return flows that accompany population growth and commercial development place stresses on water resources in the basin, including degradation of water quality and depletion or surcharge of streamflow.

Based on 1990 census data, approximately 64,500 of an estimated 140,000 households in the basin used onsite septic systems. The remaining households were served by public sewer systems. Fourteen permitted WWTPs discharge municipal wastewater to streams in the basin. Two of these facilities discharge wastewater to impaired reaches in the Brockton area. The Brockton Advanced Water Reclamation Facility (AWRF) discharges treated effluent to the Salisbury Plain River in Brockton, and the Myers Avenue Water Treatment Plant discharges filter backwash to the Shumatuscacant River in Abington (fig. 1). During the study period, the Myers Avenue plant discharge rate was relatively low, averaging about $0.063 \mathrm{Mgal} / \mathrm{d}$ (appendix 1). In contrast, the Brockton AWRF discharge rate, based on daily flow records, was much higher, averaging $20.2 \mathrm{Mgal} / \mathrm{d}$ for the period 1997-2006. This high return-flow rate substantially augments streamflow and affects water quality in stream reaches downstream from the Brockton AWRF outfall. HSPF simulations indicated that treated wastewater accounted for about 45 to 80 percent of streamflow under low-flow conditions (July through September averages for daily mean flows) for the period 1997-2006. The percentage of wastewater was higher during the driest periods. For example, simulation results indicated that treated wastewater accounted for more than 90 percent of streamflow for 32 days during the summer of 1999. The percentage of wastewater was lower during the winter and spring but still frequently exceeded 30 percent of streamflow for most years in the model calibration period. Addition of wastewater represents an increase in flow in comparison to the flow rate that would otherwise occur from natural runoff processes. Because the wastewater discharge rate is large in comparison to streamflow from runoff (that is, the drainage area is relatively small), the Matfield River below the Brockton AWRF outfall is the most surcharged stream in the State (Weiskel and others, 2009).

Because a large percentage of streamflow downstream from the outfall is composed of treated wastewater, effluent water quality substantially affects stream water quality. However, historical measurements of stream water quality downstream from the outfall may not accurately reflect current conditions because the Brockton AWRF underwent a series of upgrades between 2004 and 2008 to lower concentrations of total phosphorus, total nitrogen, and bacteria in effluent to meet current and anticipated future permit requirements (David Norton, City of Brockton, written commun., 2011). Major changes included replacement of aging equipment and upgrades to wastewater-treatment processes. Consequently, concentrations of nutrients have declined substantially since the 1999-2006 period, when most of the water-quality samples used in the current study were collected. The 1999-2008 median total phosphorus concentration in treated effluent was 0.65 milligrams per liter $(\mathrm{mg} / \mathrm{L}$ ) (Brockton Advanced Water Reclamation Facility, written commun., 2008). However, in the late 1990s, total phosphorus concentrations in monthly effluent samples frequently were around $1 \mathrm{mg} / \mathrm{L}$, whereas, by 2008 , concentrations had fallen to a range of 0.1 to $0.2 \mathrm{mg} / \mathrm{L}$. Total nitrogen in treated effluent also decreased but not as much as phosphorus (Brockton Advanced Water Reclamation Facility, written commun., 2008). The 2002-08 median total nitrogen concentration was $12.0 \mathrm{mg} / \mathrm{L}$, and daily concentrations decreased from approximately 15 to $10 \mathrm{mg} / \mathrm{L}$ over this period. Thus, for a given flow rate, effluent loads of total phosphorus and total nitrogen declined by about 80 and 30 percent, respectively, in response to plant upgrades. The 1999-2008 median total suspended solids (TSS) concentration in treated effluent was $6 \mathrm{mg} / \mathrm{L}$. Daily TSS concentrations were much more variable than nutrients, exceeding $100 \mathrm{mg} / \mathrm{L}$ on several occasions.

Drinking water is obtained from onsite private wells or public water supplies. Withdrawals from private wells that are returned to onsite septic systems have a relatively small effect on streamflow because water is cycled locally, and the net loss of water from the basin is small (Barbaro and Zarriello, 2006). In contrast, larger groundwater or surface-water withdrawals for public water supplies can have substantial effects on streamflow in the vicinity of the withdrawals and the corresponding municipal wastewater-return flows (if the households served by public water supplies are connected to public sewers). The number of households using private wells was not determined in this study, but based on examination of the 1990 census data on water use, it is likely that a majority of households in the basin are served by public water supplies. Both groundwater and surface water are used for public water supplies. For example, the City of Brockton obtains water from Monponsett Pond, Silver Lake, and water-supply wells. Water withdrawals and wastewater return flows in the impaired reach areas are described in greater detail in the HSPF model documentation section of the report (appendix 1).

\section{Precipitation-Runoff Model of the Taunton River Basin}

A precipitation-runoff model was developed and calibrated to simulate daily-mean streamflow in selected areas in the basin for the period 1997-2006. Simulated streamflow was used to estimate loads and construct yield-duration plots for water-quality data collected from the impaired stream reaches. The HSPF model was developed by (1) creating a conceptual model to represent the hydrology of the basin, (2) compiling and processing the necessary input data and constructing the model, (3) calibrating the model to improve the simulation accuracy, and (4) evaluating the performance of the calibrated 
model for streamflow simulations. Although the basic elements of the model were constructed for the entire basin, detailed accounting of water use and model calibration was done only for 20 model subbasins that represent the drainage areas to the 13 impaired reaches (fig. 5). For brevity, these areas are collectively referred to as the "impaired-reach areas" of the basin in this report. The development and limitations of the HSPF model are described in appendix 1.

\section{Description of Water-Quality and Streamflow Data Collection and Management}

Previously collected water-quality data that met dataacceptance criteria were compiled to evaluate the magnitude and spatial distribution of nutrient and sediment concentrations, estimate daily loads and yields, and conduct a yieldduration analysis for impaired stream reaches using HSPFsimulated streamflows. Previously collected water-quality data from 63 sites on the impaired reaches, tributaries to the impaired reaches, and the Taunton River near the streamgage at Titicut Street, Bridgewater were compiled for the study (table 2; fig. 5). As shown on figure 5 and discussed further in the following section, a number of these sites are colocated. Additional streamflow and water-quality data were collected in 2008 by the USGS at two locations for this study: (1) Taunton River near the Berkley Street Bridge, Dighton/ Berkley line (site number 56), and (2) Matfield River at the USGS streamgage at Elmwood, East Bridgewater (station no. 01106500; site number 14) (fig. 5). Water-quality data used in this study are tabulated in appendix 2 .

\section{Compilation of Previously Collected Water- Quality Data}

Water-quality data collected by various organizations during the model calibration period of 1997-2006 were compiled for this study. Data were collected during this period by the USGS, BSC, MEP, and MA DEP and their contractors ESS and ENSR. To be considered for use in the study, previous water-quality data were required to meet the acceptance criteria defined by Norris and others (1992). Data were screened to determine whether (1) coordinates or descriptions of site locations were available, (2) data were collected to determine ambient water quality in a stream reach or the effects of a particular source to a stream, and (3) an approved quality assurance project plan or sampling and analysis plan (QAPP/SAP) was developed for the sampling program. The second phase of the data acceptance procedure included a review of sample-collection methods and analytical results of quality-assurance samples or documentation that analytical results met data-acceptance criteria described in the QAPP/SAP. The sampling programs conducted by MA DEP and their contractors ESS and ENSR are well documented, and the analytical results met data-acceptance criteria described in their QAPP/SAPs (Massachusetts Department of Environmental Protection, 1998; ENSR, 2000; ESS Group, Inc., 2002; Massachusetts Department of Environmental Protection, 2006b). BSC analytical results met internal data-acceptance criteria based on their laboratory quality assurance plan (Watershed Access Laboratory, 2008). USGS samples were collected using standard protocols and procedures (U.S. Geological Survey, variously dated). All USGS results met applicable data-acceptance criteria (U.S. Geological Survey, 2008). Only portions of the approved MEP QAPP were available for review; however, results met applicable data-acceptance criteria (Massachusetts Department of Environmental Protection and the School of Marine Science and Technology, 2006).

Most (about 92 percent) of the previously collected water-quality samples used in this study were categorized as instantaneous "grab" samples, in which a sample bottle was dipped into the stream to obtain the sample (appendix 2). Exceptions were some of the BSC samples collected at BSCMRHS on the Matfield River (site 17) and BSC-TRTS on the Taunton River (site 54); and the USGS samples collected USGS-01106468 (site 10), and USGS-01108000 (site 53). In 1999, 2004, and 2005, BSC collected grab samples periodically over 22-hour periods using automated samplers and then calculated daily mean concentrations from the grab samples (appendix 2). Of the $66 \mathrm{BSC}$ total phosphorus samples in the dataset, 21 were daily mean concentrations from the two sites listed above; within-day differences ( $\mathrm{n}=2-8$ samples per day) between maximum and minimum total phosphorus concentrations generally were less than $0.03 \mathrm{mg} / \mathrm{L}$ (data not shown). These daily mean concentrations compose about 5 percent of the total number of total phosphorus samples used in the study. In 2000, 2002, 2006, and 2007, BSC collected grab samples only. USGS used equal-width increment (EWI) techniques (U.S. Geological Survey, variously dated) to obtain crosssectional composite samples across the stream channel; 11 instantaneous cross-sectional composite samples were used in the study.

MA DEP, ESS, and ENSR used standard laboratory analytical methods for TSS to quantify concentrations of suspended solid-phase material in surface water and are reported in this report as such. TSS was quantified at all of the sediment-data-collection-sites in the impaired-reach areas (39 sites). In contrast, USGS used standard laboratory analytical methods for suspended sediment concentration (SSC) for samples collected at site USGS-01108000 on the Taunton River (site 53) (table 3, in back of report). The fundamental difference between TSS and SSC is in sample preparation; TSS entails withdrawing an aliquot of the sample prior to filtering, drying, and weighing, whereas SSC measures all sediment and the mass of the entire sediment-water mixture in the sample (Gray and others, 2000). Studies comparing TSS and SSC indicate that SSC is the more reliable method for 


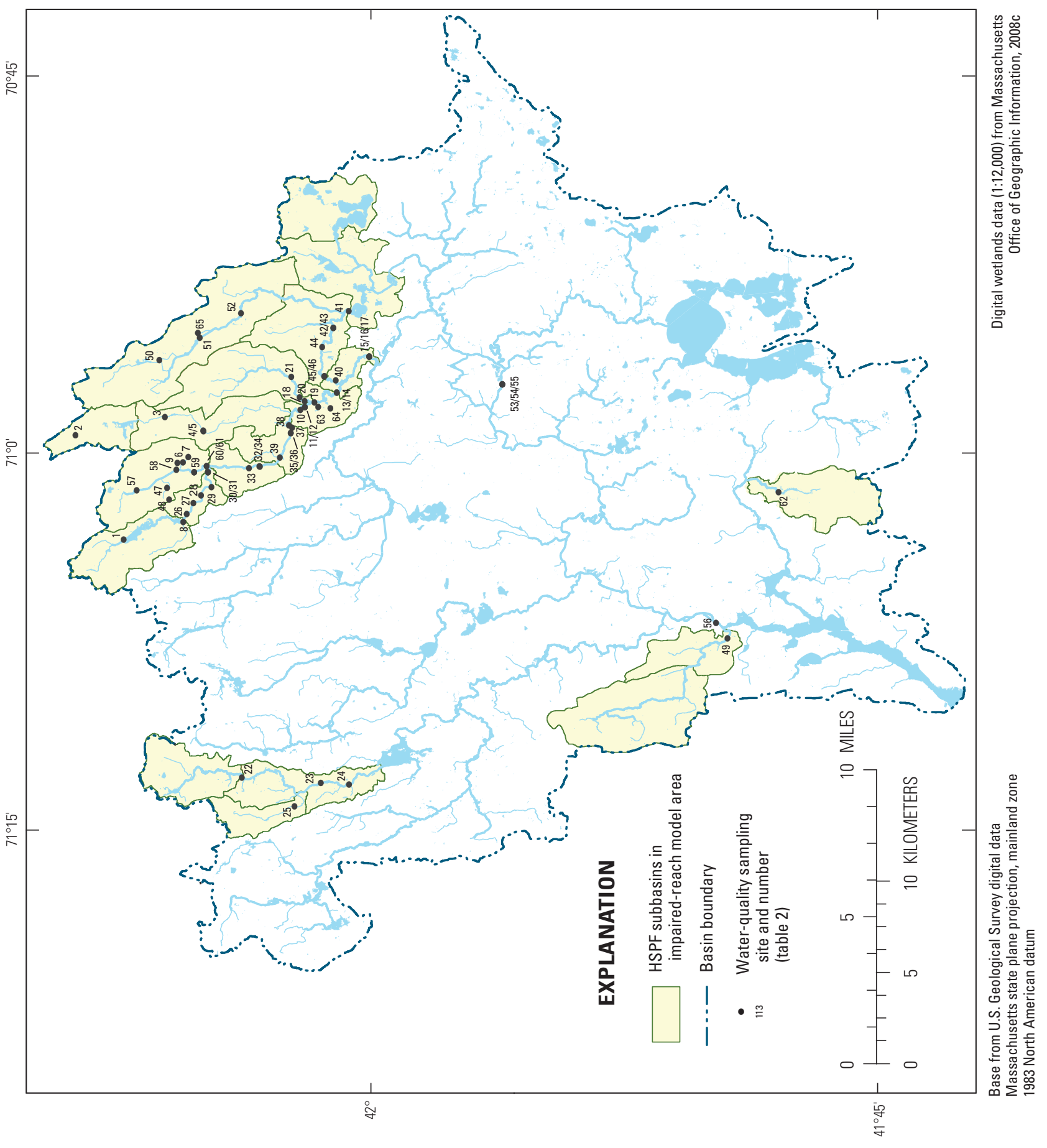


Table 2. Water-quality sampling sites in the Taunton River Basin, Massachusetts.

[WWTP, wastewater treatment plant; Water-quality site name prefixes are defined as follows: BSC, Bridgewater State College; ENSR, ENSR, Inc.; ESS, ESS Group, Inc.; MHB, Mount Hope Bay-Massachusetts Estuaries Project; MADEP, Massachusetts Department of Environmental Protection; USGS, U.S. Geological Survey. Shaded row indicates water-quality sampling site located outside of the impaired-reach model areas. USGS collected data for this study at site numbers 14 (Matfield River at USGS streamgage near Elmwood, East Bridgewater) and 56 (Taunton River downstream from Berkley Bridge, Dighton/Berkley line). Water-quality data for these sites are in appendix 2. Site locations are shown in figures 5 and 6 ]

\begin{tabular}{|c|c|c|c|}
\hline $\begin{array}{l}\text { Site } \\
\text { number }\end{array}$ & Location & $\begin{array}{l}\text { Water-quality sampling } \\
\text { site name }\end{array}$ & Site description \\
\hline 1 & Beaver Brook & ESS-ABB1 & Upstream from Old Pond Street, Avon \\
\hline 2 & Beaver Brook & ESS-BB3 & Downstream from bridge on Plymouth Street, Holbrook \\
\hline 3 & Beaver Brook & ESS-BB2 & $\begin{array}{l}\text { Downstream from bridge on East Ashland and Groveland Streets, Brockton/ } \\
\text { Abington line }\end{array}$ \\
\hline 4 & Beaver Brook & ESS-BB1 & Downstream from bridge on Crescent Street (Route 27), Brockton \\
\hline 6 & Cary Brook & ESS-CB1 & Downstream from bridge on Elliot Street, Brockton \\
\hline 7 & Cary Brook & ESS-CB2 & Downstream from bridge on Court Street, Brockton \\
\hline 8 & Lovett Brook & ESS-LB1 & DW Field East Parkway, upstream from Ellis Brett Pond, Brockton \\
\hline 9 & Malfardar Brook & ESS-MAB1 & North Cary Street, upstream from intersection with Ashfield Drive, Brockton \\
\hline 13 & Matfield River & ESS-MR2 & Downstream from bridge on Bedford Street (Route 18), East Bridgewater \\
\hline $14^{*}$ & Matfield River & USGS-01106500 & USGS streamgage at Elmwood, East Bridgewater (01106500) \\
\hline 15 & Matfield River & ESS-MR1 & Upstream from bridge on High Street, Bridgewater \\
\hline 16 & Matfield River & MADEP-MATR00 & High Street, Bridgewater \\
\hline 17 & Matfield River & BSC-MRHS & High Street, Bridgewater \\
\hline 18 & Matfield River & ESS-MB1 & Downstream from bridge on West Union Street, East Bridgewater \\
\hline 19 & Matfield River & BSC-MRSS & Spring Street, Bridgewater \\
\hline 20 & Meadow Brook & MADEP-MDWBRK00 & West Union Street, East Bridgewater \\
\hline 21 & Meadow Brook & BSC-MBRUS & Union Street, East Bridgewater \\
\hline 28 & Salisbury Brook & ESS-SB4 & End of Montgomery Avenue, Brockton \\
\hline 29 & Salisbury Brook & ESS-SB2 & Chester Avenue, Brockton \\
\hline 30 & Salisbury Brook & ESS-SB1 & Upstream from bridge on Otis Street, Brockton \\
\hline 31 & Salisbury Brook & MADEP-SALBRK00 & Otis Street, Brockton \\
\hline 32 & Salisbury Plain River & ESS-SPR3 & East of Main Street (Route 28), Brockton \\
\hline 33 & Salisbury Plain River & ESS-SPR2 & Downstream from bridge on Plain Street, Brockton \\
\hline 34 & Salisbury Plain River & MADEP-SALPR01 & Sargent's Way (upstream from the Brockton WWTP), Brockton \\
\hline 35 & Salisbury Plain River & BSC-SPRBS & Belmont Street, West Bridgewater \\
\hline 36 & Salisbury Plain River & ESS-SPR1 & Downstream from bridge on Belmont Street, West Bridgewater \\
\hline 37 & Salisbury Plain River & MADEP-SALPR00 & Matfield Street (downstream from the Brockton WWTP), East Bridgewater \\
\hline 38 & Salisbury Plain River & BSC-SPRPS & Pleasant Street, East Bridgewater \\
\hline 39 & Salisbury Plain River & BSC-SPRASTP & Downstream from Brockton WWTP, West Bridgewater \\
\hline
\end{tabular}


Table 2. Water-quality sampling sites in the Taunton River Basin, Massachusetts.-Continued

[WWTP, wastewater treatment plant; Water-quality site name prefixes are defined as follows: BSC, Bridgewater State College; ENSR, ENSR, Inc.; ESS, ESS Group, Inc.; MHB, Mount Hope Bay-Massachusetts Estuaries Project; MADEP, Massachusetts Department of Environmental Protection; USGS, U.S. Geological Survey. Shaded row indicates water-quality sampling site located outside of the impaired-reach model areas. USGS collected data for this study at site numbers 14 (Matfield River at USGS streamgage near Elmwood, East Bridgewater) and 56 (Taunton River downstream from Berkley Bridge, Dighton/Berkley line). Water-quality data for these sites are in appendix 2. Site locations are shown in figures 5 and 6 ]

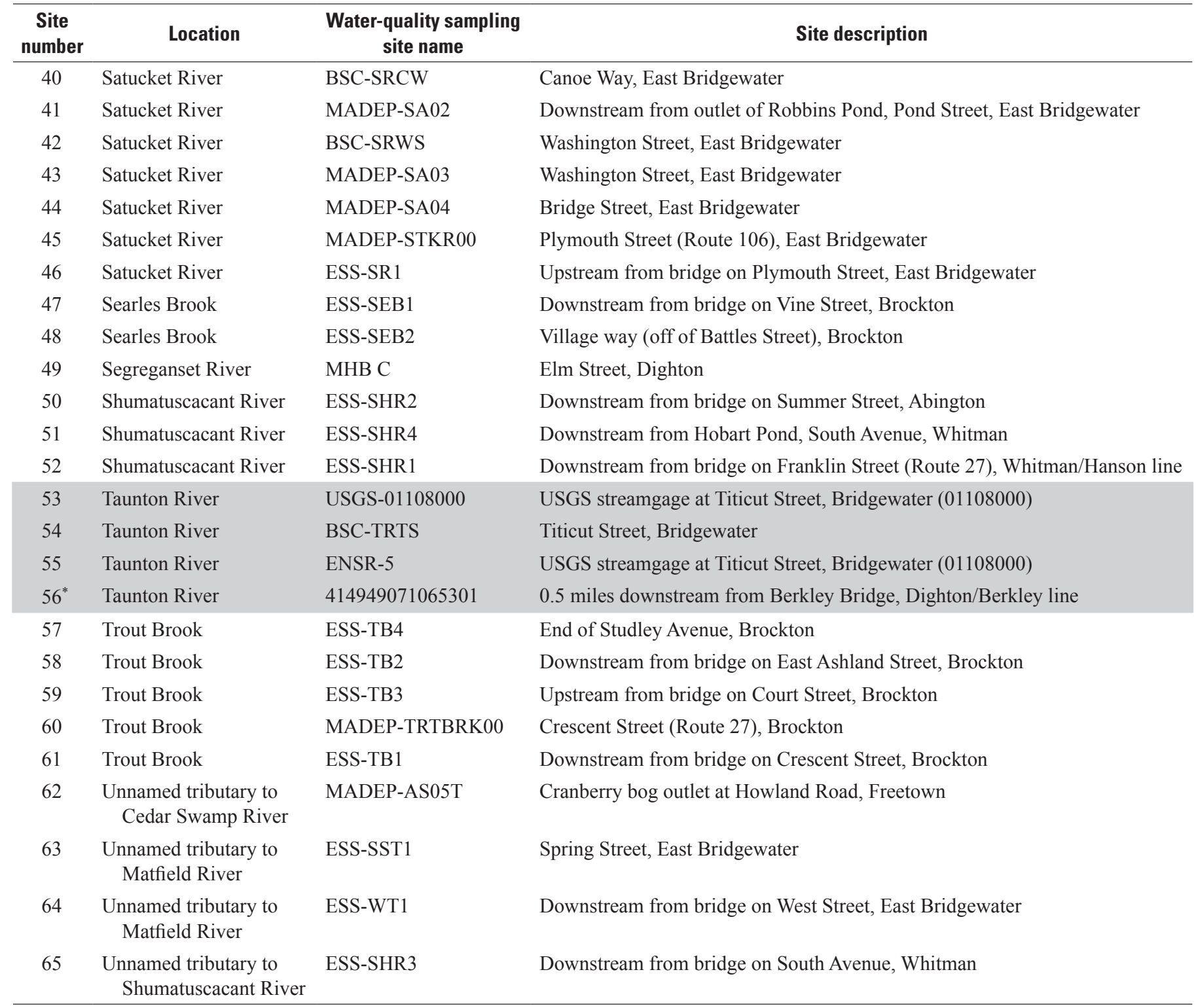

*2008 USGS sampling sites (this study). All other sampling sites are from previous studies. 
measuring the mass of solid-phase material in water, and that TSS will often underestimate sediment concentration, particularly when the percentage of sand-sized material (greater than 0.062 millimeter diameter for very fine sand) in the sample exceeds about a third (Gray and others, 2000). However, when the percentage of sand-sized material is lower, as is likely the case in the samples collected from the Taunton River Basin because stream gradients are relatively low and samples were collected mainly during low-flow nonstorm events, TSS and SSC are more comparable. For brevity, because nearly all of the samples in the dataset were analyzed for TSS, sediment data are collectively referred to as TSS in this report.

Of the 63 water-quality sampling sites from previous studies used in this study, 60 were in the impaired-reach model area (table 2; fig. 6). In nine locations in the drainage area to the Matfield River, samples were collected by different organizations at different times from the same location. Consequently, samples were collected from 49 unique locations in the impaired-reach areas (fig. 6). Most of the sites are on the impaired reaches, but small tributaries to the impaired reaches also were sampled in some areas. For example, sites $6,7,9,47$, and 48 are on tributaries to Trout Brook (MA6207), sites 63 and 64 are on tributaries to the Matfield River (MA62-32), and site 65 is on a tributary to the Shumatuscacant River (MA62-33) (fig. 6A). Other sites, for example in HSPF subbasins 23, 26, and 31, are in reaches not designated as impaired; these sites are included in the study because they are in drainage areas to impaired reaches. The number of sampling sites in impaired reaches varied substantially. The Matfield River, Salisbury Plain River, and Trout Brook had the most sampling sites (fig. 6A), whereas the Segreganset River had the fewest sites with only one site (site 49) downstream from the end of impaired reach MA62-54 (fig. 6C). The three sampling sites on the Taunton River at the USGS streamgage (site 53, 54, and 55) also are colocated (fig. 5).

Sampling sites generally were not located at the mouths of HSPF subbasins (the model nodes where streamflows were simulated) or the downgradient ends of the impaired reaches. Consequently, drainage area ratios were computed to apportion simulated flows to sampling sites to estimate loads (table 3, in back of report). The total drainage area to most of the sampling sites ( 39 of 60 sites) is greater than 75 percent of the total drainage area to the mouth of the HSPF subbasin in which the site is located.

Most of the sites were sampled between one and five times over the course of a 1- to 6-month sampling program (table 3, in back of report). At some sites (for example, MA DEP sites sampled in 2006), the same set of constituents was not analyzed for each sampling event, so that the total number of samples differs by constituent at those sites. Sites with more extensive water-quality records include: USGS-01106468 (former USGS streamgage, North Central Street, East Bridgewater, site 10), which was sampled 11 times between April 2000 and September 2004 (Riskin and others, 2003); BSC-MRHS (High Street, Bridgewater, site 17), which was sampled 34 times between May 1999 and August 2006;
MHB C (Elm Street, Dighton, site 49), which was sampled 81 times between May 2004 and December 2005; BSC-TRTS (USGS streamgage, Bridgewater, site 54), which was sampled 33 times between June 1999 and August 2006; and USGS01108000 (USGS streamgage, Bridgewater, site 53), which was sampled 23 times between March 1997 and August 2002. The colocated BSC-TRTS and USGS-01108000 sites are not on an impaired reach, but they are located on the main stem of the Taunton River upstream from the tidally influenced part of the river and provide information on nutrient loading to the lower Taunton River from the upper part (49 percent) of the basin.

Most samples were collected under dry-weather conditions (defined here as less than $0.1 \mathrm{in}$. of precipitation in the 48 -hour period preceding the sampling event). Antecedent rainfall over this period was less than $0.1 \mathrm{in}$. for 66 percent of the sampling events, and less than 0.25 in. for 74 percent of the sampling events (appendix 2). In addition, most sampling took place during the summer months; 78 percent of the samples in the dataset were collected between June and September. As indicated above, only three sampling sites (USGS-01106468, MHB C, and USGS-01108000) were sampled in other seasons. If site MHB C, which was sampled multiple times over an 18-month period, is omitted, then 85 percent of the samples were collected between June and September. Most of the remaining 15 percent of the samples in the dataset were collected in May, October, or November. Thus, seasonal effects on concentrations are not expected to have a substantial effect on the dataset used in the analysis.

Constituents measured at the sampling sites in the impaired-reach areas varied by organization and sampling program (table 3, in back of report). Total phosphorus (phosphorus in unfiltered samples) was analyzed most frequently; samples were collected from 58 of 60 sites. Samples analyzed for TSS were collected from 39 of 60 sites. Of the nitrogen species, unfiltered samples analyzed for ammonia plus organic nitrogen (also known as Kjeldahl nitrogen) were collected from the most sites ( 38 of 60 sites). Total nitrogen (nitrate + nitrite + ammonia + organic nitrogen in unfiltered samples) was analyzed less frequently ( 13 of 60 sites). For most of the USGS sites, total nitrogen was calculated from individual nitrogen species, which included filtered nitrate plus nitrite data; samples from other organizations were reported as total nitrogen. Other nutrient data that were collected at only a few sites include: dissolved ammonia, nitrite, nitrate plus nitrite, and ammonia plus organic nitrogen; organic phosphorus; and dissolved orthophosphate (appendix 2).

\section{U.S. Geological Survey Water-Quality and Streamflow Data Collection}

The USGS collected water-quality samples and measured streamflow in 2008 at sites USGS-414949071065301 (Taunton River near the Berkley Bridge, a tidally influenced site about 0.5-mi downstream from the Berkley Bridge, 


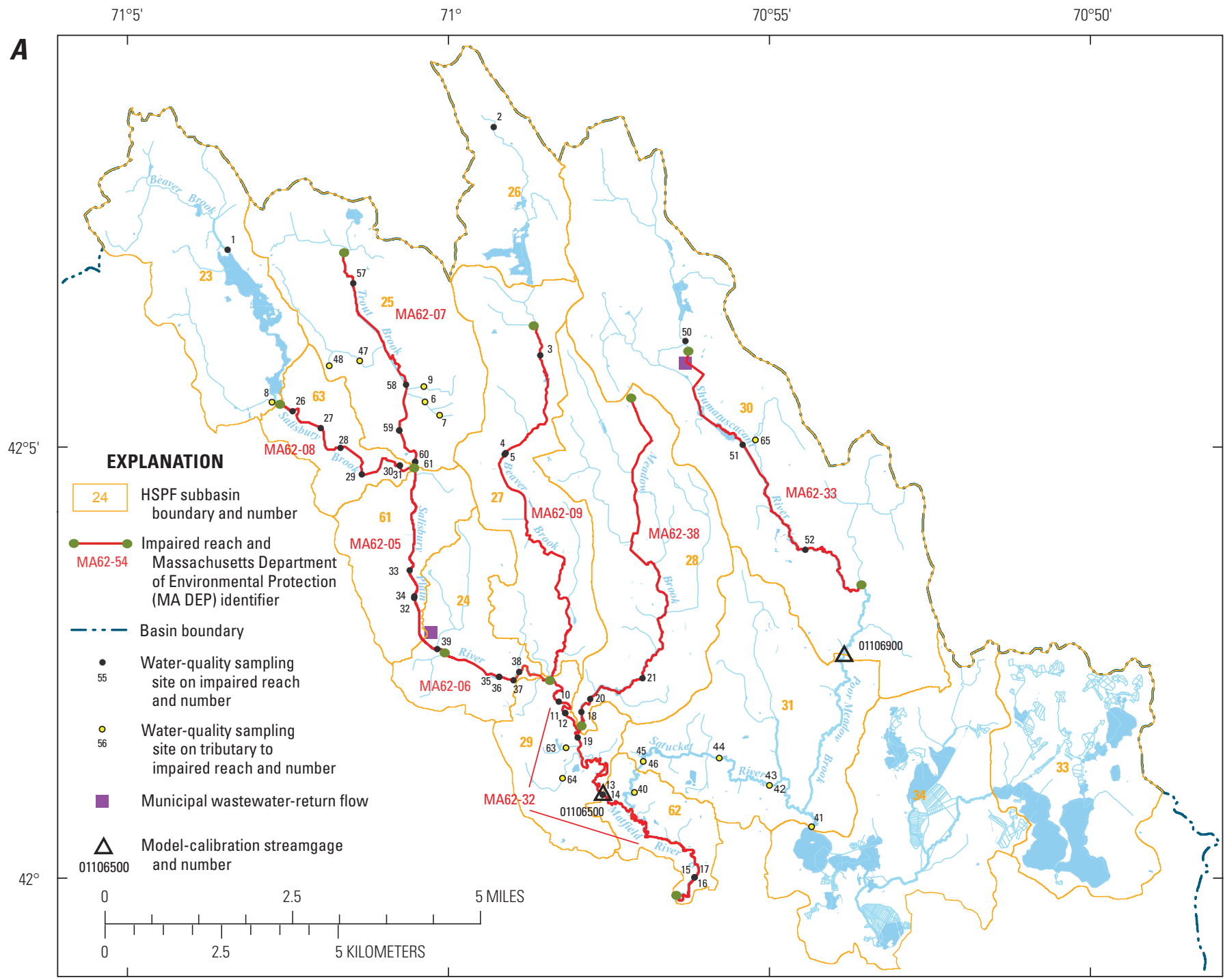

Base from U.S. Geological Survey digital data

Massachusetts state plane projection, mainland zone

1983 North American datum

Figure 6. Water-quality sampling sites, Hydrological Simulation Program-FORTRAN (HSPF) model reaches, and impaired reaches in drainage areas to $A$, the Matfield River, $B$, the Rumford River, and $C$, Segreganset River and unnamed tributary to Cedar Swamp River, Taunton River Basin, Massachusetts. Water-quality sampling sites described in table 2. 


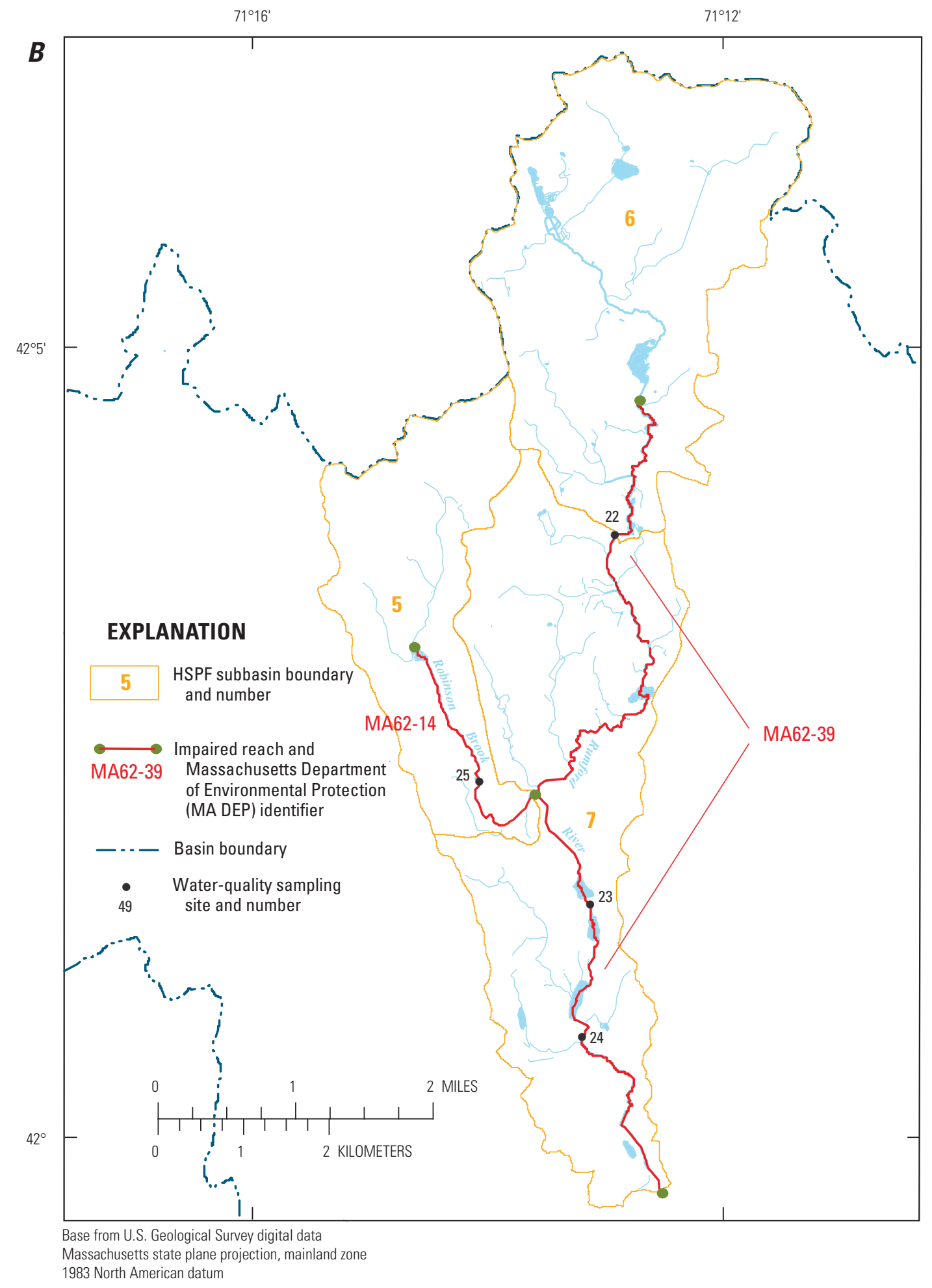

Figure 6. Water-quality sampling sites, Hydrological Simulation Program-FORTRAN (HSPF) model reaches, and impaired reaches in drainage areas to $A$, the Matfield River, $B$, the Rumford River, and $C$, Segreganset River and unnamed tributary to Cedar Swamp River, Taunton River Basin, Massachusetts. Water-quality sampling sites described in table 2.-Continued 


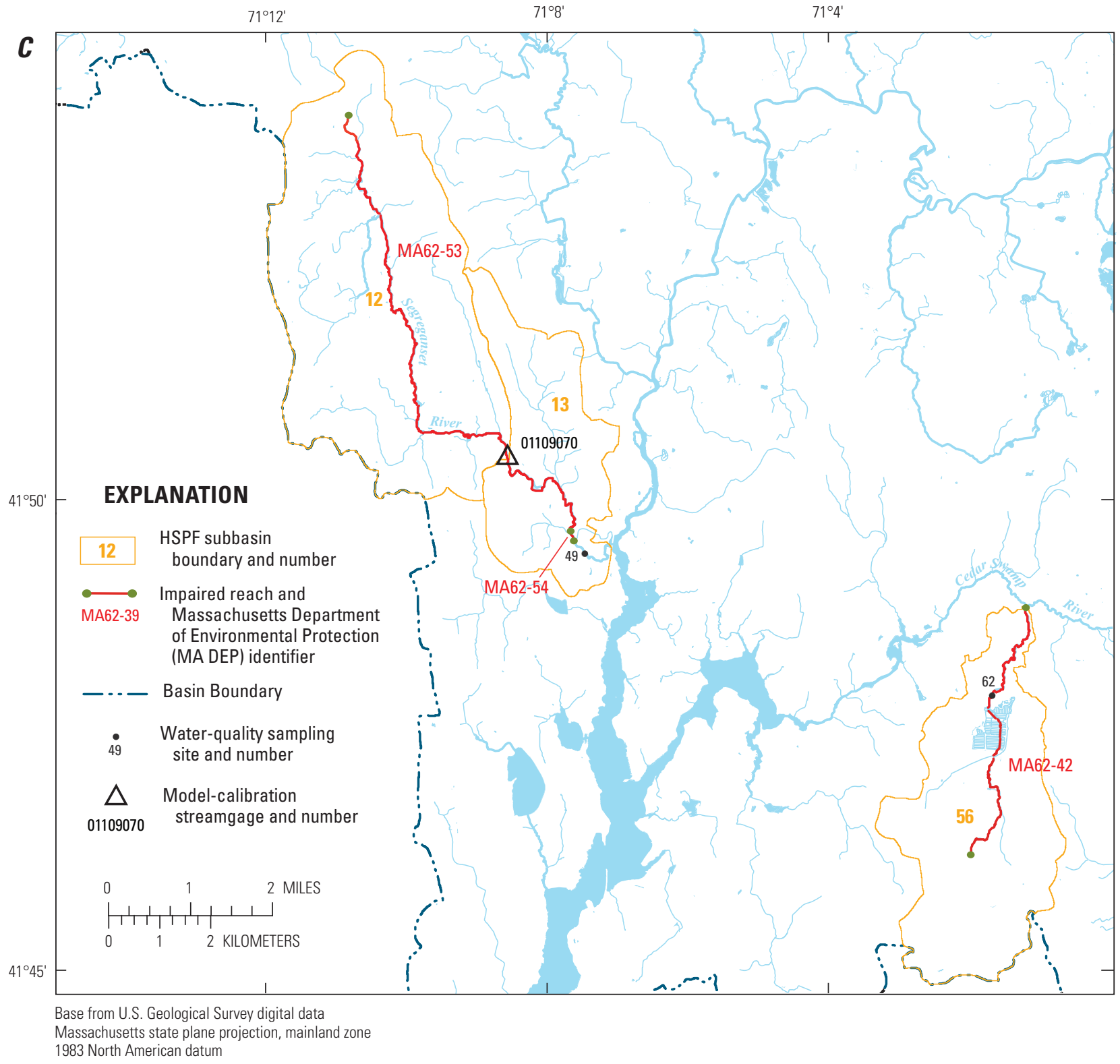

Figure 6. Water-quality sampling sites, Hydrological Simulation Program-FORTRAN (HSPF) model reaches, and impaired reaches in drainage areas to $A$, the Matfield River, $B$, the Rumford River, and $C$, Segreganset River and unnamed tributary to Cedar Swamp River, Taunton River Basin, Massachusetts. Water-quality sampling sites described in table 2.-Continued 
Dighton/Berkley line, site 56), and USGS-01106500 (USGS streamgage on the Matfield River at Elmwood, East Bridgewater, site 14). These sites were sampled to (1) determine recent (2008) nutrient and chlorophyll $a$ concentrations and loads under a range of flow conditions using sampling methods that provided discharge-weighted, cross-sectional composite samples, and (2) obtain continuous records of basic water-quality data (temperature, specific conductance, $\mathrm{pH}$, and dissolved oxygen) to be archived for possible use in the calibration of a water-quality model. Data collection at the Berkley Bridge site was timed to coincide with slack water at low tide to measure freshwater nutrient loads from the main stem of the Taunton River to Mount Hope Bay. In addition to composite samples, grab samples were collected at both sites. Results from grab samples were compared to those from cross-sectional composite samples to determine the representativeness of grab samples at these sites. All data are in the USGS National Water Information System (NWIS) database.

\section{Streamflow Measurements}

Streamflow measurements were made at the Taunton River site during three water-quality sampling events in May, September, and November 2008, and at the Matfield River site during one sampling event in May 2008 (table 4). The May and September events were conducted during relatively wet periods (about 0.5 -in. of precipitation fell in the previous 48 hours) (appendix 2). The November event was conducted during a drier period (0.04-in. of precipitation fell in the previous 48 hours).

At the Matfield River, daily streamflow data were available from the USGS streamgage site (station no. 01106500) for all water-quality sampling dates, and the streamflow measurement at this site was made only to compare streamflow at the sampling transect with flow at the streamgage. The streamflow measurement was conducted in conjunction with the May 19, 2008, sampling event and was within 5 percent of the flow measured at the streamgage. The maximum depth along the 40 -ft transect was about $4 \mathrm{ft}$. The composite sampling events in May, September, and November occurred at the 48th, 51 st, and 70th percentiles of flow, respectively, based on the 1997-2006 simulated streamflow record at the streamgage.

The Taunton River site was tidally influenced. Sampling and flow measurements were timed to coincide with minimum stage during slack water at low tide to maximize the amount of freshwater from upstream flowing past the transect during data collection. The river was about $250 \mathrm{ft}$ wide and had a maximum depth of about $13 \mathrm{ft}$ at minimum stage at the sampling site. Measurements were made with an Acoustic Doppler Current Profiler (ADCP) aboard a 16-ft flat-bottomed boat or canoe that was pulled along the transect perpendicular to flow using a temporary tagline set up prior to each sampling event. This approach provided stable working conditions and permitted a constant rate of speed for flow measurements and water-quality sampling. Minor salinity corrections and rapid changes in stage because of tidal processes were accounted for in the streamflow measurements. The quality of all three flow measurements at the Taunton River site were considered good.

Daily mean streamflows from the operational USGS streamgages upstream from the Taunton River sampling site (Taunton River at Titicut Street, Bridgewater, station no. 01108000; Mill River at Spring Street, Taunton, station no. 01108410; and ThreeMile River at North Dighton, station no. 01109060) were summed and compared to the measured flows in the Taunton River (table 5) to determine whether the instantaneous streamflow measurements at low stage were consistent with gaged daily flows to the river on the day of measurement. Locations of these streamgages are shown on figure 1-3 of appendix 1 . Together, the drainage areas to the upstream streamgages $\left(390 \mathrm{mi}^{2}\right)$ represent about 85 percent of the drainage area to the Taunton River sampling site $\left(459 \mathrm{mi}^{2}\right)$. To compare the gaged streamflows to the instantaneous measured flows, the summed daily mean flows from the upstream streamgages were adjusted by the drainage-area ratio of 1.178 to estimate the daily mean flow at the Taunton River sampling site. The instantaneous measured flows at the sampling site exceeded the adjusted summed daily mean flows from the upstream streamgages on all three sampling dates (table 5). Measured flows exceeded gaged flows by factors of 2.4 on May 19, 2008, 4.1 on September 15, 2008, and 2.0 on November 14, 2008. This disparity likely reflects an oscillating rate of freshwater discharge in response to tidal inflows and outflows. When the tide is rising, saline water flows upstream causing freshwater flow to slow down or cease and temporarily fall below the daily mean flow, whereas when the tide ebbs, freshwater flow resumes but at a rate that temporarily exceeds the daily mean flow. Consequently, the adjusted summed flows from the upstream streamgages were considered to be more representative of daily mean streamflow than the instantaneous measured flows, and the summed flows were used to estimate freshwater nutrient loading to Mount Hope Bay at the Taunton River site. Based on the 2006-9 summed streamflow record at upstream gages, composite sampling events and streamflow measurements at the Taunton River site in May, September, and November 2008 occurred at about the 48th, 64th, and 61st percentiles of flow, respectively.

\section{Continuous Field Parameter Data Collection}

Continuous (15-minute interval) water-quality data were collected at the Taunton River and Matfield River sites with a Eureka water-quality multiprobe (data not shown). Six field parameters were measured: temperature, $\mathrm{DO}, \mathrm{pH}$, specific conductance, turbidity, and chlorophyll $a$. At the Taunton River site, continuous water-quality data were collected from July 29, 2008, to December 4, 2008, after which ice flows destroyed the site. Data gaps in the record occurred from August 21 to September 15, and from October 15 to November 6 . At the Matfield River site, water-quality data were collected from July 29, 2008, to May 13, 2009. Data gaps in the Matfield River record occurred from August 27 to September 15, October 20 to November 6, and December 4 to 9. 


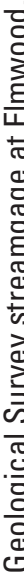

它鸹

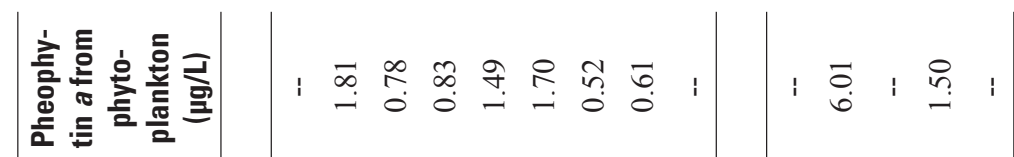

0 请

है ส

可

责

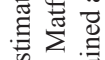

c)

究范哭

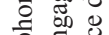

部焉

क

要击

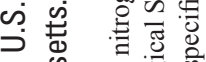

垔

츄

$\sum_{i}^{\infty}$

Z. 능

过

它

드. 달

退

$\sum^{\frac{1}{\Phi}}$

50 昆

. 항

i 용

б

\&

क

党

吅

하

电

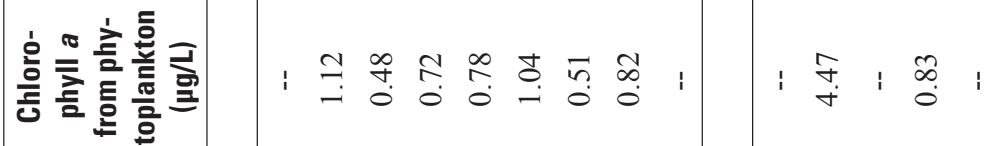

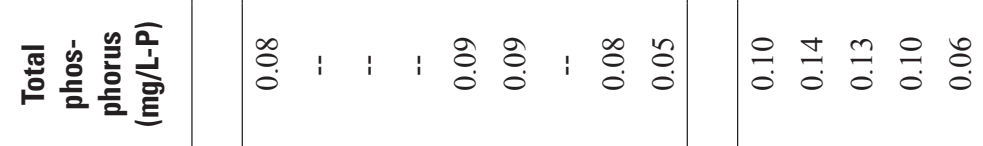

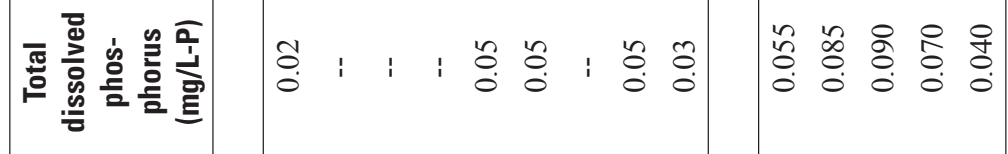

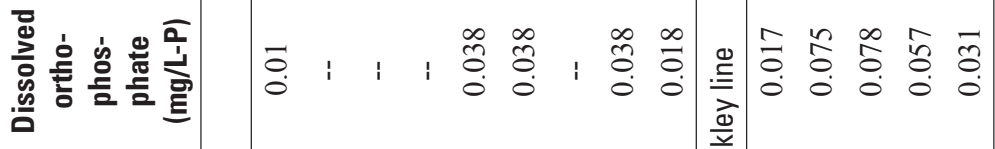

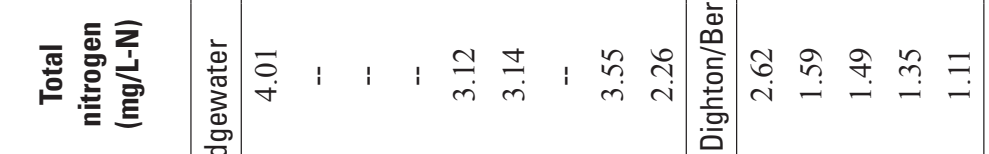

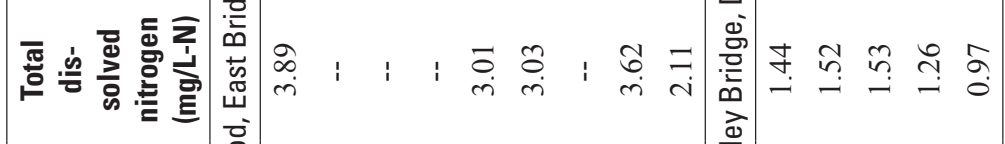

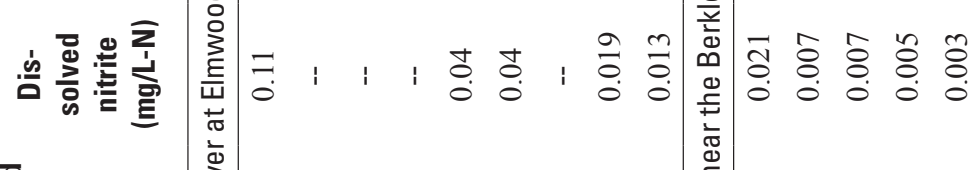

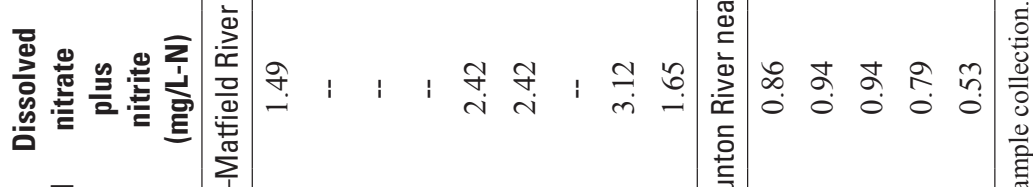

要

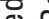

टे

흥 등

政

志要 竞

邓

ङ ऐ है है

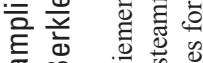

क्ष

흔

I

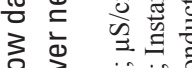

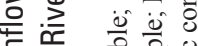

드 들 율

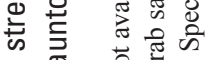

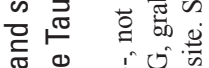

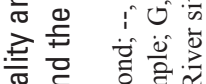

흠 당

迹苛

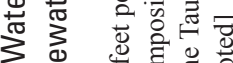

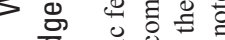

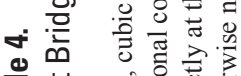

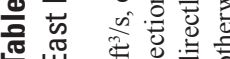

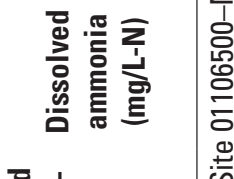

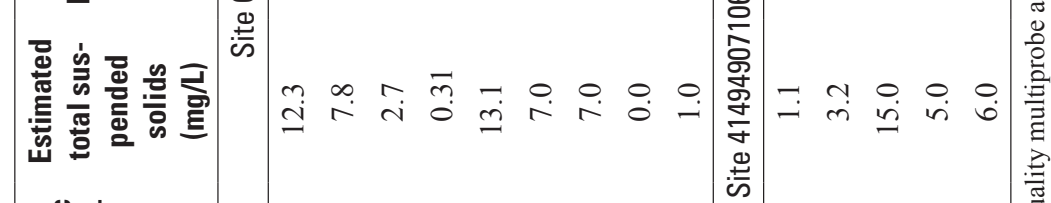

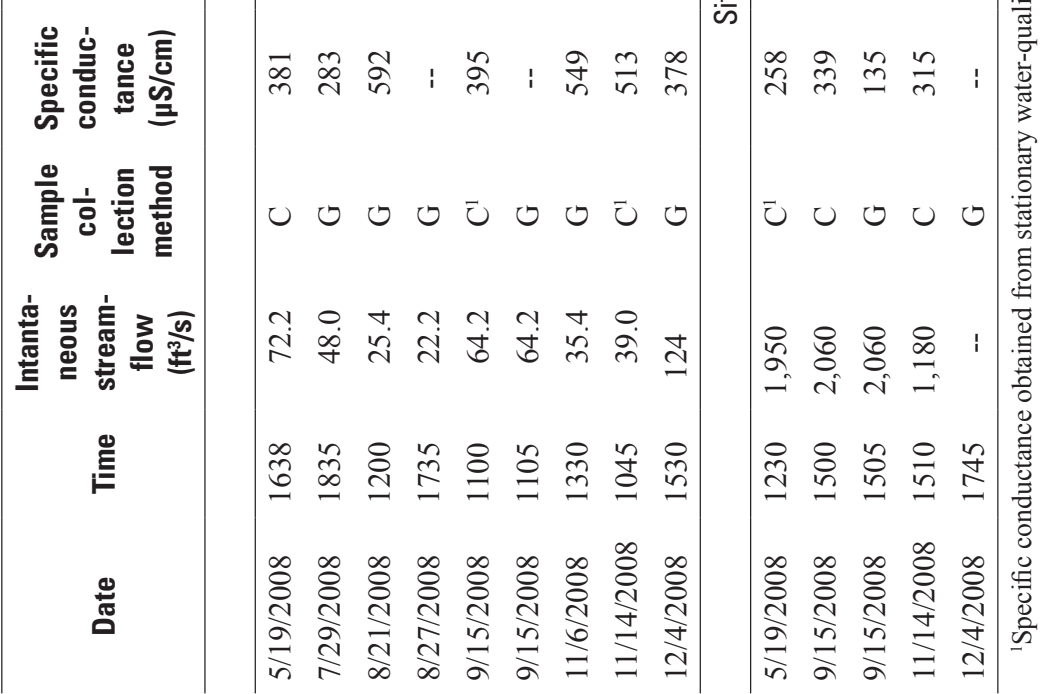




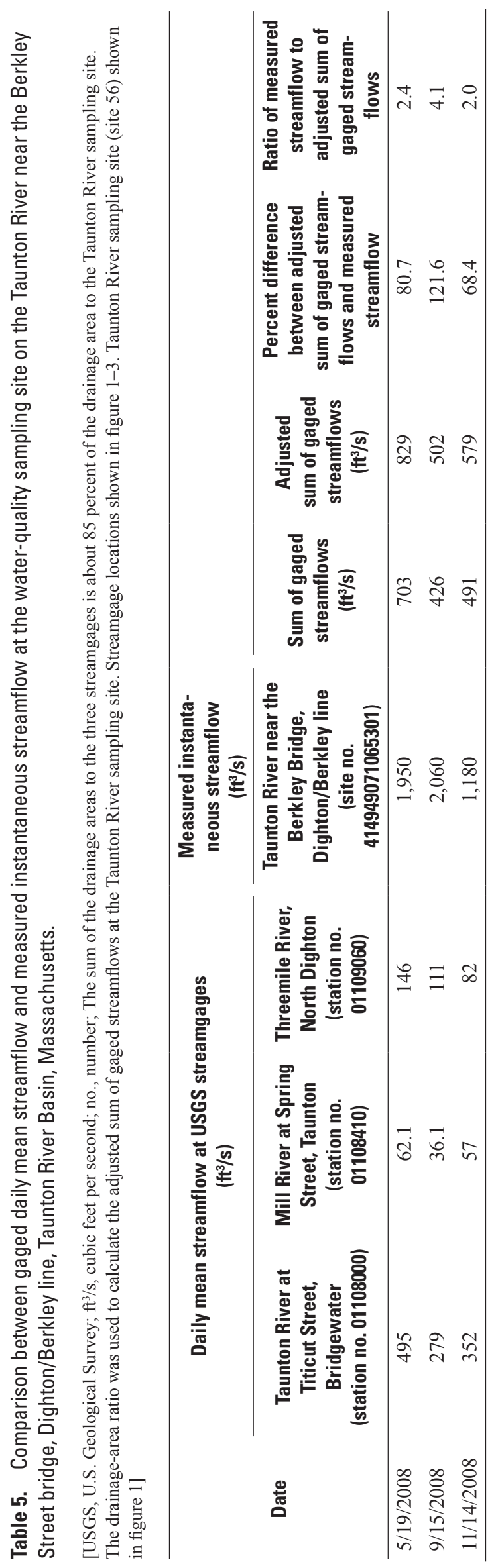


An additional calibrated multiprobe was used to obtain profiles of temperature, specific conductance, $\mathrm{DO}, \mathrm{pH}$, and depth along sampling transects during the September and November composite sampling events at the Taunton River site, and the May composite sampling event at the Matfield River site. The sampling interval for these data varied from 30 seconds to 1 minute The percent differences between transect and stationary measurements at the Matfield River site were less than 10 percent for all parameters. The percent differences between stationary and transect measurements at the Taunton River site were less than 15 percent, with the exception of specific conductance. Differences in specific conductance between stationary and transect measurements were about 80 and 20 percent for the September and November sampling events, respectively. Transect measurements included deeper locations where water was slightly more saline compared to the location of the stationary multiprobe at the edge of the channel. Overall, however, specific conductance concentrations across the channel were low (mean cross-sectional concentration of about 300 microsiemens per centimeter $(\mu \mathrm{S} / \mathrm{cm})$ compared to seawater (approximately 50,000 $\mu \mathrm{S} / \mathrm{cm}$; Hem, 1985) and were similar to the Matfield site (table 4). These data therefore indicate a negligible amount of saline water was mixed with the freshwater flowing downstream across the transect at the Taunton River site. In addition, these comparisons indicate that field-parameter data from the stationary multiprobes were reasonably representative of the water quality across the entire cross-sectional areas at these sampling sites.

\section{Water-Quality Sample Collection}

Water-quality sampling was conducted four times (five samples) at the Taunton River site and eight times (nine samples) at the Matfield River site between May and December 2008 (table 4). Samples were analyzed for one or more of the following constituents: total suspended solids, nitrogen species (dissolved ammonia, dissolved nitrate plus nitrite, dissolved nitrite, total dissolved nitrogen, and total nitrogen), phosphorus species (dissolved orthophosphate, total dissolved phosphorus, and total phosphorus), chlorophyll $a$, and pheophytin $a$ (table 4). All samples were analyzed by the USGS National Water Quality Laboratory (NWQL) in Lakewood, Colorado. Inorganic constituents were analyzed using methods described in Fishman (1993) and Fishman and Friedman (1989). Chlorophyll $a$ and pheophytin $a$ in phytoplankton were analyzed by methods in Arar and Collins (1997). TSS data in table 4 are referred to as "Estimated total suspended solids" because concentrations were calculated from residue on evaporation in laboratory filtered and unfiltered samples, rather than from a standard analytical method for suspended solids. Laboratory and field equipment blank and duplicate samples all met acceptance criteria outlined in the QAPP developed for the study (U.S. Geological Survey, 2008). Field and laboratory data are stored in the USGS NWIS database.
Cross-sectional composite samples were collected with temporary taglines set up across the sampling transects. At the Matfield River site, average stream velocities generally were greater than 2 feet per second ( $\mathrm{ft} / \mathrm{s}$ ) with a maximum depth of about $4 \mathrm{ft}$. Samples therefore were collected following EWI, isokinetic sampling techniques for wadeable streams, as described by Lane and others (2003). Samples were collected along the tagline with a USGS DH-81 manual sampler equipped with a $1 / 4$-in. nozzle and a 3 -liter (L) precleaned polypropylene bottle. At the Taunton River site, composite samples were collected from a boat moving along the temporary tagline. Because flows generally were lower than the $1.6 \mathrm{ft} / \mathrm{s}$ minimum velocity required to use USGS D-95 isokinetic sampling techniques (Lane and others, 2003), a modified approach was used to collect composite samples. Precleaned peristaltic pump tubing was attached to a calibrated multiprobe set to log continuously to measure basic water-quality parameters as the composite sample was collected. To collect the sample, the multiprobe/pump intake assembly was lowered and raised through the water column at a constant vertical rate of about $1 \mathrm{ft} / \mathrm{s}$ as the boat moved slowly across the transect at a constant rate of speed. The sample was pumped directly into a precleaned churn splitter at a constant rate of about $1 \mathrm{~L} / \mathrm{min}$.

In addition to the composite samples, grab samples were collected periodically from both sites. Grab samples collected on September 15, 2008, coincided with composite samples; the remaining grab samples were collected on different dates. Constituent concentrations in grab samples and composite samples collected on the same day compared well to each other for most constituents (table 4). Percent differences were less than 10 percent, with the exception of TSS at both sites and chlorophyll $a$ at the Matfield River site. Consistent with the multiprobe data, these comparisons indicate that grab samples are reasonably representative of water quality across the entire cross-sectional area of the stream at these sampling sites. However, at the Taunton River site, this conclusion likely only applies when sampling is done at minimum stage during low tide.

\section{Nutrient and Sediment Concentrations}

The magnitude and spatial distribution of nutrient and sediment concentrations are described in this section. Concentrations of these constituents ranged over two to three orders of magnitude in the impaired reaches and the main stem of the Taunton River, and the spatial distribution of concentration in the impaired reaches shows the effects of diffuse and point sources.

\section{Previously Collected Water-Quality Data}

Median concentrations were computed for all total phosphorus, total nitrogen, and TSS samples collected from the sampling sites in the impaired-reach areas between 1999 
and 2006. Total phosphorus concentrations ranged from 0.0046 to $0.91 \mathrm{mg} / \mathrm{L}$ in individual samples $(\mathrm{n}=331$ ), with a median of $0.090 \mathrm{mg} / \mathrm{L}$. Total nitrogen concentrations ranged from 0.34 to $14 \mathrm{mg} / \mathrm{L}$ in individual samples ( $\mathrm{n}=139$ ), with a median of $1.35 \mathrm{mg} / \mathrm{L}$. TSS concentrations ranged from less than 1 to $69 \mathrm{mg} / \mathrm{L}$ in individual samples ( $\mathrm{n}=155$ ), with a median of $5.3 \mathrm{mg} / \mathrm{L}$. For TSS concentrations reported as less than the detection limit of $1 \mathrm{mg} / \mathrm{L}$, the detection-limit value was used to calculate medians. To avoid biasing the data analysis because of unequal numbers of samples among the sampling sites, medians first were calculated at each sampling site for sites sampled three or more times (table 3 , in back of report). The overall median then was computed as the median of the site medians. Concentrations of these constituents at the Taunton River at Titicut Street, Bridgewater site, which is downstream from the mouth of the Matfield River, generally were within the ranges described above for the impaired reach sites (table 3, in back of report).

To compare concentrations among impaired reaches, the median of the sampling-site medians on each reach was calculated (sampling sites on tributaries to the impaired reaches were excluded from the calculation). Because all of the data collected between 1999 and 2006 were used, samples were collected under variable flow conditions, but, as indicated in the previous section, most of the data were obtained under lower-flow conditions during the summer months. Reaches MA62-14 (Robinson Brook) and MA62-42 (unnamed tributary to Cedar Swamp River) had too few samples to compute medians, MA62-33 (Shumatuscacant River) had no total nitrogen data, and MA62-53/43 (Segreganset River) had no TSS data. For the remaining reaches, median total phosphorus concentrations ranged from $0.016 \mathrm{mg} / \mathrm{L}$ in the Rumford River (MA62-39) to $0.22 \mathrm{mg} / \mathrm{L}$ in the upper Matfield River (MA6232) (table 6). Median total nitrogen concentrations ranged from $0.61 \mathrm{mg} / \mathrm{L}$ in the Rumford River (MA62-39) to $6.2 \mathrm{mg} / \mathrm{L}$ in the lower Salisbury Plain River (MA62-06). Median TSS concentrations ranged from $2 \mathrm{mg} / \mathrm{L}$ in the Rumford River (MA62-39) to $8 \mathrm{mg} / \mathrm{L}$ in Trout Brook (MA62-07).

Median concentrations of nutrients were highest in the lower Salisbury Plain and Matfield Rivers, the reaches downstream from the Brockton AWRF outfall. In the remaining impaired reaches affected only by diffuse sources, median concentrations were lower than in reaches below the outfall and generally increased with the percentage of developed land in the drainage area to the reach (data not shown). A Spearman rho rank correlation test was used to evaluate relations between median concentration and the percentage of developed land in the drainage area to the reach. Correlations were considered significant if the probability was less than 5 percent $(\mathrm{p}<0.05)$. Correlation coefficients for reaches affected by diffuse sources only were $0.667(\mathrm{p}=0.07)$ for total phosphorus $(\mathrm{n}=8)$, and $0.750(\mathrm{p}=0.05)$ for both total nitrogen and TSS $(n=7)$. These correlations provide only a rough approximation of the relation between concentration and development because the percentage of development in the drainage area pertains to the mouth of the reach, whereas, the median concentrations are from sampling sites at different locations along the reach. In some reaches, for example MA62-09 (Beaver Brook) and MA62-39 (Rumford River) and MA62-07 (Trout Brook), sampling sites are located substantial distances upstream from the mouth, and the percentage of developed land in the drainage areas to these sites may differ from the percentage of developed land in the total drainage area to the mouth. The finding that nutrient concentrations increase as a function of anthropogenic inputs to the watershed is consistent with many other studies (for example, Omernik, 1977; Howarth and others, 1996; Boyer and others, 2002).

Concentrations of total phosphorus and total nitrogen were elevated compared to various published water-quality guidelines (also commonly referred to as water-quality criteria or threshold concentrations) in most of the samples collected from the impaired reaches. Although phosphorus is often considered to be the dominant nutrient controlling algal and macrophyte growth in freshwater streams (Correll, 1998), other work indicates that nitrogen and phosphorus can control primary productivity in at least some streams (Dodds and Welch, 2000); consequently, guidelines for both nutrients are considered here. Published nutrient guidelines represent threshold concentrations expected to limit eutrophication, defined as excessive algal and macrophyte growth, low DO, and increased turbidity, in freshwater streams. Dodds and others (1997) define nuisance levels of benthic chlorophyll $a$ as densities above 100 milligrams per square meter (mg/ $\mathrm{m}^{2}$ ) and suggest that instream total phosphorus and total nitrogen concentrations should be maintained below 0.030 and $0.35 \mathrm{mg} / \mathrm{L}$, respectively. However, the algal densities that represent nuisance levels are subjective, and a fairly wide range of nutrient criteria have been published, depending on the desired outcome to limit eutrophication (Dodds and Welch, 2000). Overall, the relation between nutrient concentrations and eutrophication is less understood in streams than in lakes (Riskin and others, 2003), and excessive algal growth may not be the most appropriate indicator of enrichment. For example, excessive macrophyte growth can be problematic in New England streams, and the relation between macrophyte growth and instream nutrient concentrations often is weak, perhaps indicating that nutrients are obtained predominantly from the sediment (Allan and Castillo, 2007). Consequently, to assess the extent of nutrient enrichment in the Taunton River Basin, it may be more reasonable to compare concentrations in the impaired reaches to concentrations published for reference streams in the northeast.

Reference streams are defined as minimally affected streams with low nutrient concentrations that are expected to limit nuisance algal growth. In a USGS National Water-Quality Assessment (NAWQA) Program study, Black Brook near Manchester, New Hampshire (station no. 01090477) and the Stillwater River near Sterling, Mass. (station no. 01095220) were selected as minimally affected reference streams for nutrient concentrations and algal biomass (Riskin and others, 2003). Black Brook and the Stillwater River were sampled five and eight times, respectively, in the summer of 2001. Median 


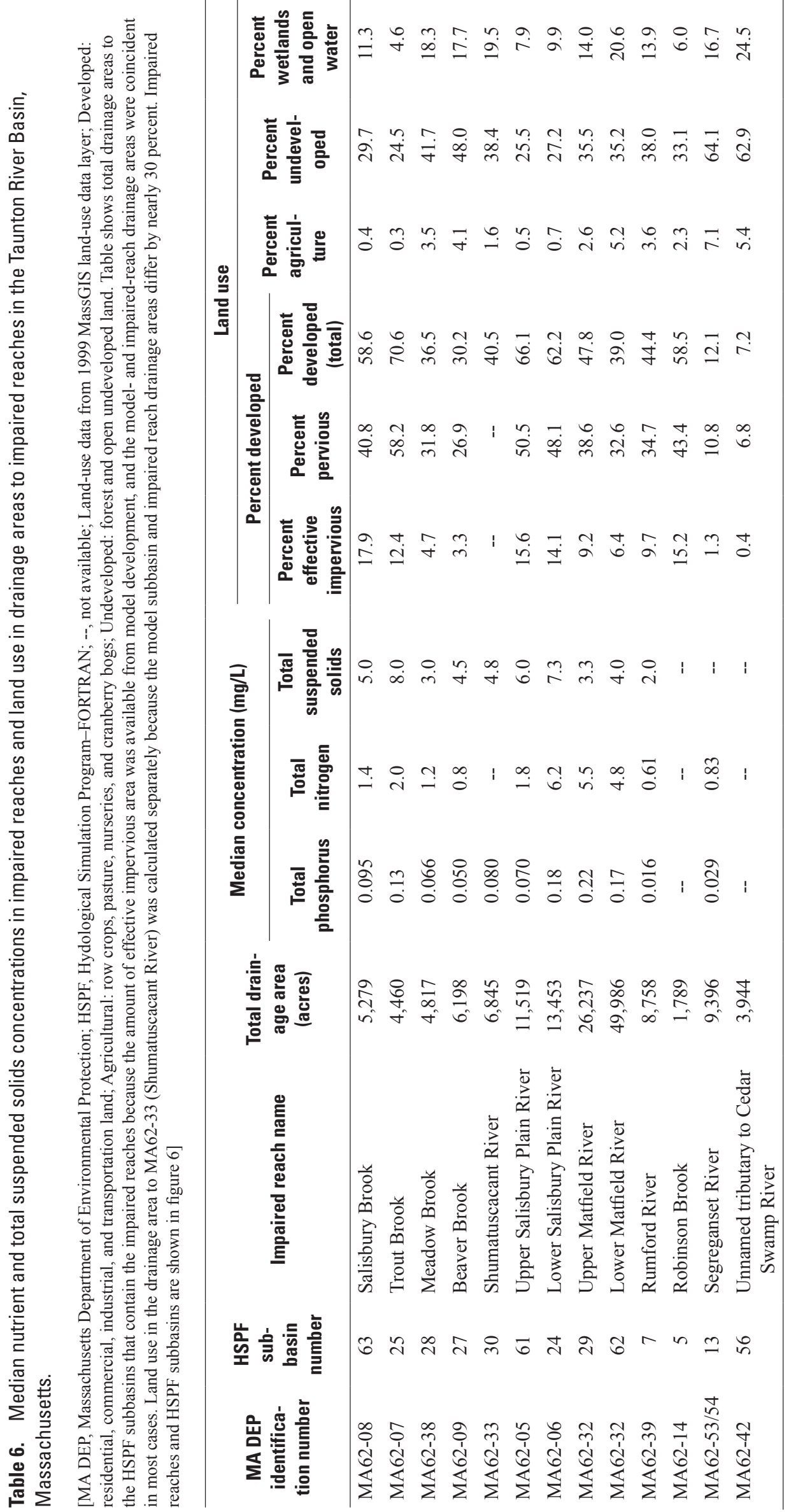


concentrations of total nitrogen and total phosphorus in the reference streams $(0.44 \mathrm{mg} / \mathrm{L}$ total nitrogen and $0.018 \mathrm{mg} / \mathrm{L}$ total phosphorus) were substantially lower than median concentrations at the impaired-reach sampling sites $(1.35 \mathrm{mg} / \mathrm{L}$ total nitrogen and $0.090 \mathrm{mg} / \mathrm{L}$ total phosphorus).

Concentrations in the impaired reaches also can be compared to concentrations in streams in EPA ecoregion 14, subecoregion 59 (U.S. Environmental Protection Agency, 2000). Subecoregion 59 extends from northern New Jersey to southern Maine. Although the 75th percentile concentration for reference streams is considered to be adequately protective of designated uses and determining this percentile of the reference stream sample is the preferred method for establishing a threshold nutrient concentration, reference streams were not identified for subecoregion 59 (U.S. Environmental Protection Agency, 2000). When reference streams have not been identified, the 25 th percentile concentration for all streams may be used for a threshold concentration, because the 25 th percentile concentration for all streams was found to be comparable to the 75th percentile concentration for reference streams in other regions. However, it should be noted that EPA also recommends that water-resources managers modify or refine these regional criteria to reflect site-specific conditions. The 25th percentile total phosphorus and total nitrogen concentrations for subecoregion 59 are $0.024 \mathrm{mg} / \mathrm{L}(\mathrm{n}=87$ sites) and $0.57 \mathrm{mg} / \mathrm{L}$ ( $\mathrm{n}=14$ sites), respectively (table 7 ). These values are the medians of the 25 th percentile concentrations for the four seasons, where the values in the seasonal distributions are medians of samples collected from each stream. Twenty-fifth percentile total nitrogen and phosphorus concentrations in subecoregion 59 streams were lower than the median concentrations at the impaired-reach sites. Thus, nutrient concentrations in a majority of samples collected from the impaired-reach areas exceeded threshold concentrations in USGS and EPA reference streams in the northeast.

\section{U.S. Geological Survey Water-Quality Data}

At the Matfield River site, total nitrogen concentrations ranged from 2.26 to $4.01 \mathrm{mg} / \mathrm{L}$ and total phosphorus concentrations ranged from 0.05 to $0.09 \mathrm{mg} / \mathrm{L}$ (table 4). Concentrations of total suspended solids at this site ranged of 0.0 to $13.1 \mathrm{mg} / \mathrm{L}$. Comparison of the May through December 2008 data from the Matfield River site with June through September 2002 data from colocated site ESS-MR2 (table 3, in back of report) indicates that TSS concentrations were higher (medians of $7 \mathrm{mg} / \mathrm{L}$ in 2008 and $4 \mathrm{mg} / \mathrm{L}$ in 2002) in 2008, whereas total phosphorus concentrations were lower by about 60 percent (medians of $0.08 \mathrm{mg} / \mathrm{L}$ in 2008 and $0.20 \mathrm{mg} / \mathrm{L}$ in 2002) in 2008. The small sample sizes notwithstanding, lower total phosphorus concentrations in 2008 may reflect recent (20048) upgrades to treatment processes at the Brockton AWRF, as described in the Water Withdrawals and Wastewater-Return Flows section of the report. A lower total phosphorus concentration at this site in 2008 is consistent with reductions in concentrations in treated effluent that occurred in response to plant upgrades.

At the Taunton River site, total nitrogen concentrations ranged from 1.11 to $2.62 \mathrm{mg} / \mathrm{L}$ and total phosphorus concentrations ranged from 0.06 to $0.14 \mathrm{mg} / \mathrm{L}$. Concentrations of total suspended solids at this site ranged from 1.1 to $15.0 \mathrm{mg} / \mathrm{L}$. Chlorophyll $a$ and pheophytin $a$ from phytoplankton, indirect measures of phytoplankton algal biomass, ranged from about 0.6 to $6 \mu \mathrm{g} / \mathrm{L}$ at these sites. As discussed previously, the specific conductance at the Taunton River site was about the same as at the Matfield River site, indicating that Taunton River results were representative of freshwater constituent concentrations.

Table 7. Total nitrogen and total phosphorus concentrations in U.S. Geological Survey reference streams in New Hampshire and eastern Massachusetts, and U.S. Environmental Protection Agency subecoregion 59 streams.

[mg/L, milligrams per liter; <, less than; --, not available; USGS, U.S. Geological Survey; EPA, U.S. Environmental Protection Agency]

\begin{tabular}{|c|c|c|c|c|c|c|c|c|c|}
\hline Constituent & Minimum & $\begin{array}{c}\text { 10th } \\
\text { percentile }\end{array}$ & $\begin{array}{c}\text { 25th } \\
\text { percentile }\end{array}$ & $\begin{array}{c}\text { 50th } \\
\text { percentile }\end{array}$ & $\begin{array}{c}\text { 75th } \\
\text { percentile }\end{array}$ & $\begin{array}{c}\text { 90th } \\
\text { percentile }\end{array}$ & Maximum & $\begin{array}{l}\text { Number } \\
\text { of sites }\end{array}$ & $\begin{array}{c}\text { Total number } \\
\text { of samples }\end{array}$ \\
\hline \multicolumn{10}{|c|}{ USGS reference streams in Massachusetts and New Hampshire } \\
\hline Total nitrogen $(\mathrm{mg} / \mathrm{L})$ & 0.32 & 0.35 & 0.40 & 0.44 & 0.48 & 0.53 & 0.57 & 2 & 13 \\
\hline Total phosphorus $(\mathrm{mg} / \mathrm{L})$ & 0.0060 & 0.011 & 0.017 & 0.018 & 0.021 & 0.035 & 0.043 & 2 & 13 \\
\hline \multicolumn{10}{|c|}{ EPA subecoregion 59 streams } \\
\hline Total nitrogen $(\mathrm{mg} / \mathrm{L})$ & 0.40 & -- & 0.57 & -- & -- & -- & 2.13 & 14 & 512 \\
\hline Total phosphorus (mg/L) & 0.0025 & -- & 0.024 & -- & -- & -- & 0.91 & 87 & 8,458 \\
\hline
\end{tabular}




\section{Nutrient and Sediment Loads and Yields}

Simulated streamflow and water-quality data were used to estimate loads and yields of total phosphorus, total nitrogen, and TSS and develop yield-duration plots for all impaired reaches with sufficient water-quality data. Yield-duration plots also were developed for two sites on the Taunton River to assess nutrient and sediment loading to Mount Hope Bay; measured streamflow was used to compute yields at these sites. Daily loads and yields are considered to be estimates because (1) instantaneous concentrations from grab or crosssectional composite samples composed most (about 95 percent of samples at 61 of 63 sampling sites) of the dataset and were assumed to be representative of daily mean concentrations, and (2) simulated daily mean streamflows were used in load calculations for most of the water-quality sampling sites.

Three streamgages (Matfield River at Elmwood, East Bridgewater (station no. 01106500); Poor Meadow Brook at South Hanson (station no. 01106900); and Segreganset River near Dighton (station no. 01109070)) were used to calibrate the model for streamflow in the impaired-reach areas. The drainage areas to most of the impaired reaches were ungaged, but water-use stresses in these areas were represented in the model, and the calibrated model was considered to represent the hydrology of the basin well enough to use the simulated streamflow in the analysis. However, as discussed in the Model Limitations section of appendix 1, simulation results from ungaged areas of the basin have a relative high degree of uncertainty. For the yield-duration analysis, simulated flow was used to calculate measured yields and threshold-yield curves, so model error was less likely to affect an assessment of relative differences.

\section{Loads Calculated from Previously Collected Water-Quality Data}

Water-quality data collected by various organizations during the model calibration period (1997-2006) were used to estimate daily loads in the impaired-reach areas. Because streamflow typically was not measured during sample collection, it was necessary to use the nearest downstream simulated flow for the load calculation (that is, the simulated flow at the mouth of an HSPF reach was used to estimate loads for all sampling sites within the HSPF subbbasin). To determine the daily load at a given sampling site, the simulated daily mean streamflow on the day of sample collection was adjusted for drainage-area differences between the sampling site and the mouth of the HSPF subbasin (table 3, in back of report). Thus, daily flows were assumed to vary in proportion to the drainage area. The adjusted flow then was multiplied by the instantaneous or daily mean concentration (for total phosphorus at two BSC sampling sites) to estimate the daily load. The drainage area ratio exceeds 90 percent at 29 of 60 impaired-reach sampling sites and 75 percent at 39 of 60 sites, so adjustments to simulated flows were fairly minor at most sites.

Daily loads were estimated for total phosphorus, total nitrogen, and TSS for every sampling event in which these constituents were measured during the model calibration period (table 8 , in back of report). For TSS concentrations reported as less than the detection limit of $1 \mathrm{mg} / \mathrm{L}$, the detection-limit value was used to calculate the load. Daily total phosphorus loads in the impaired-reach areas ranged from 0.0 pound per day $(\mathrm{lb} / \mathrm{d})$ (simulated no-flow conditions on September 18, 2001 at site MADEP-AS05T in impaired reach MA62-42) to $324 \mathrm{lb} / \mathrm{d}$ at site BSC-MRHS near the mouth of the Matfield River in impaired reach MA62-32. Daily total nitrogen loads ranged from $4.54 \mathrm{lb} / \mathrm{d}$ at site MADEP-BVRBRK01 in impaired reach MA62-09 to 2,390 lb/d at site USGS-01106468 in impaired reach MA62-32. Daily TSS loads ranged from $0 \mathrm{lb} / \mathrm{d}$ at sites MADEP-AS05T on the dates shown above to 27,200 lb/d at site ESS-MR2 in impaired reach MA62-32. Because of higher concentrations and flows, daily loads generally were higher in the reaches below the Brockton AWRF outfall compared to reaches affected only by diffuse sources, but a detailed comparison of loads by impaired reach is difficult for this spatially and temporally varied dataset because loads are dependent on streamflow on the day of data collection. Daily loads at the sites near the USGS streamgage at Titicut Street, Bridgewater (BSC-TRTS, ENSR-5, and USGS-01108000), calculated using measured daily mean flows from this streamgage, generally were much higher than at sites in the impaired-reach areas (table 8, in back of report) because the drainage area to this site includes much of the upper Taunton River Basin, including the drainage areas for the Town, Winnetuxet, and Nemasket Rivers in addition to the Matfield River.

\section{Loads from 2008 U.S. Geological Survey Water- Quality Data}

Daily loads were estimated for all constituents measured during 2008 at the Matfield River at Elmwood and Taunton River near the Berkley Bridge sites (table 9). At the Matfield River site, daily mean flows from the streamgage (station no. 01106500) were used to estimate loads. At the tidally influenced Taunton River site, summed daily mean flows from three upstream USGS streamgages were used to compute loads (table 5). Detailed descriptions of the gaged daily mean flows for this site are provided in the Streamflow Measurements section of the report. As for the previously collected data, instantaneous concentrations from grab or cross-sectional composite samples were assumed to be representative of daily mean concentrations.

At the Matfield River site, daily loads in 2008 for TSS, total phosphorus, and total nitrogen ranged from 0.0 to 4,840 lb/d, 19.9 to $33.7 \mathrm{lb} / \mathrm{d}$, and 881 to $1,580 \mathrm{lb} / \mathrm{d}$, respectively (table 9). For the Taunton River site, as discussed in the Streamflow Measurements section of the report, the daily 


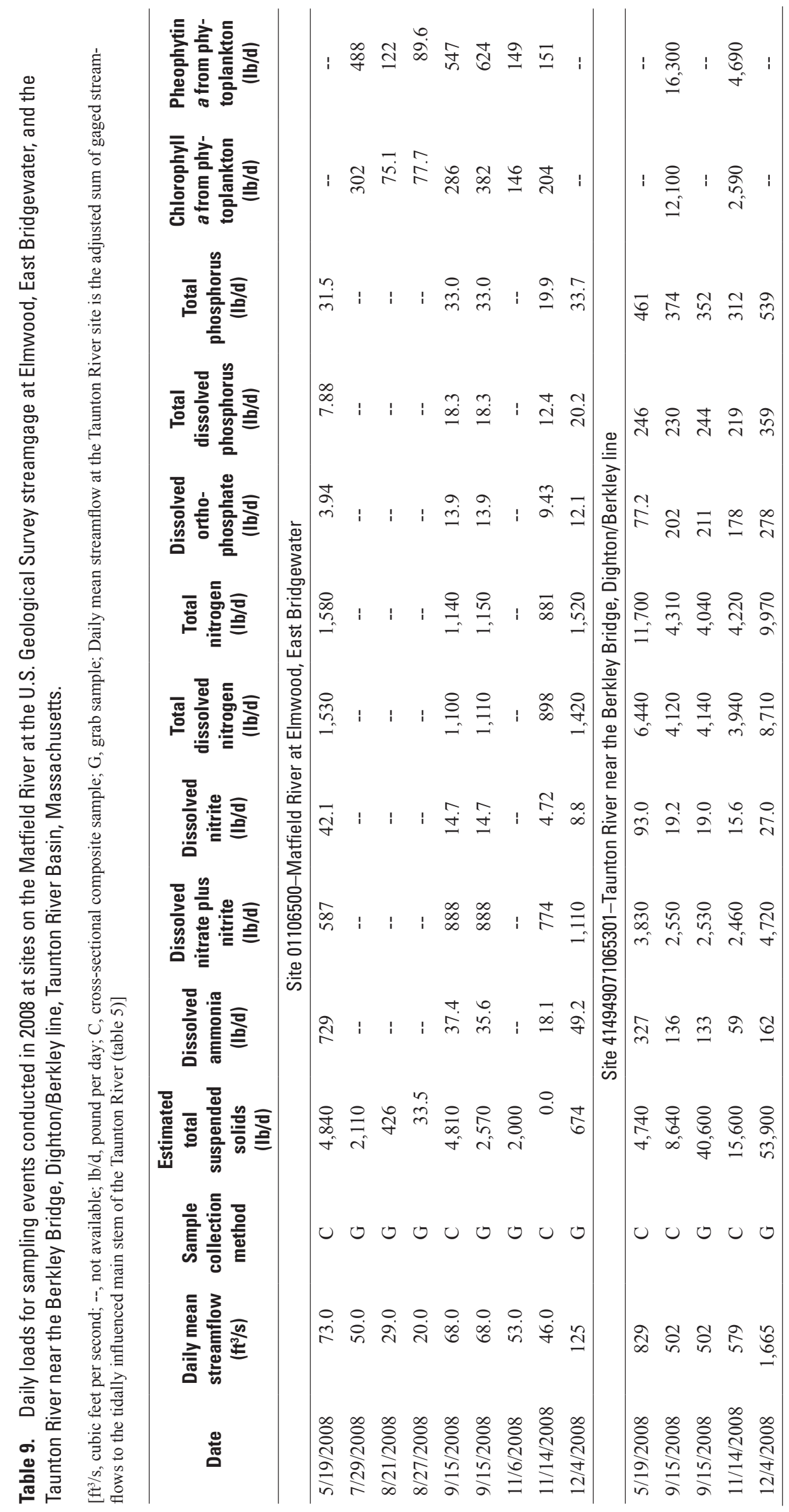


loads computed from upstream gaged daily mean flows are considered to be more representative of freshwater loads delivered from the Taunton River to Mount Hope Bay than the instantaneous loads estimated with instantaneous streamflow measured at the time of sample collection when the tide was at its lowest ebb. At the Taunton River site, daily loads in 2008 for TSS, total phosphorus, and total nitrogen ranged from 4,740 to $53,900 \mathrm{lb} / \mathrm{d}, 312$ to $539 \mathrm{lb} / \mathrm{d}$, and 4,040 to $11,700 \mathrm{lb} / \mathrm{d}$, respectively (table 9 ).

\section{Yield-Duration Analysis}

Yield-duration analysis was used to compare measured yields to threshold-yield curves constructed for a wide range of streamflow. The analysis uses of a flow-duration curve, which shows the percentage of time specified discharges are equaled or exceeded for a given period of record, without regard to chronology of occurrence (Leopold, 1994). Low flows are exceeded most of the time and have high exceedance probabilities, whereas high flows are not exceeded very often and have low exceedance probabilities. In the impaired-reach areas, simulated daily mean flow for the model calibration period of 1997-2006 were used to develop flow-duration curves. A flow-duration curve was constructed for each of the 20 HSPF subbasins in the impaired-reach model area.

Measured daily mean flow was used to construct flowduration curves for the two sites on the main stem of the Taunton River (USGS streamgage at Titicut Street, Bridgewater, and sampling site 414949071065301 near the Berkley Bridge, Dighton/Berkley line).

A threshold-yield curve for a given site is developed from a flow-duration curve by multiplying the daily flow values by a water-quality guideline, which typically represents an allowable or threshold concentration for a constituent. The resulting curve represents threshold loads over a wide range of flows (that is, the flow regime). Measured daily loads are then added to the plot and compared to the threshold-load curve. If a measured daily load plots above the threshold-load curve, it exceeds the threshold load for that flow. Conversely, a measured load that plots below the curve does not exceed the threshold.

To facilitate comparisons within an impaired reach, all measured and threshold loads were divided by the corresponding drainage area to compute yields (load per unit area). For each impaired reach with sufficient data, plots (referred to as "yield-duration plots" in the following sections) were prepared showing threshold-yield curves and measured yields for all data collected from the reach. Data from tributaries to the impaired reaches were not shown on these plots. Because yield is the load divided by the size of the drainage area, it is a metric that determines the drainage areas that export the largest constituent loads independent of their size. For example, nutrient yields from watersheds with extensive development typically are higher than yields from undeveloped watersheds.
In contrast, constituent loads typically increase with the drainage area (and magnitude of flow) and therefore are a measure of the actual mass per unit time entering or leaving a reach.

Advantages of the load-duration approach are (1) it allows for an evaluation of loading across the entire flow regime, (2) it makes use of all relevant streamflow and waterquality data at a given site, and (3) it may provide important information about the nature of an impairment based on when (for example, high compared to low flow) excessive loads occur (Cleland, 2002 and 2003). For example, measured yields or loads that plot above the threshold curve during low-flow conditions (flows exceeded about 85 to 99 percent of the time) may be indicative of constant, point sources such as municipal wastewater discharge or base-flow contributions. In contrast, yields or loads that plot above the threshold curve during high-flow conditions (flows exceeded about 1 to 15 percent of the time) may be indicative of wet-weather processes such as nonpoint source runoff, or mobilization of sediment and particulate organic matter in the channel. Wet-weather exceedances of threshold curves developed from a single water-quality criterion are expected for total phosphorus, total nitrogen, and TSS because concentrations of these constituents typically increase with discharge. Elevated yields or loads at mid-range flows are less easy to interpret, but they may indicate that multiple sources contribute to the impairment. Disadvantages of the approach are (1) identification of specific sources is difficult and typically limited to wet-weather diffuse sources compared to dry-weather point sources, and (2) "what if" scenarios to evaluate linkages between source alteration and the corresponding response in water quality and loading cannot be conducted, as could be done with a calibrated watershed model.

In the Taunton River Basin, there were sufficient total phosphorus, total nitrogen, and TSS data to construct yieldduration plots for most of the impaired reaches, which allows for an assessment of spatial variability of daily yield, flow conditions under which threshold yields are exceeded, and reconnaissance-level source identification. Wet-weather yields generally could not be evaluated because most water-quality data were collected under nonstorm conditions. Because most of the water-quality data used in the yield-duration analysis were collected in the early 2000 s, the analysis is most representative of conditions in the impaired reaches during that time period.

\section{Water-Quality Guidelines}

The State of Massachusetts, to date (2012), has not established nutrient or sediment guidelines (or threshold concentrations) for rivers and streams in Massachusetts. An assessment of nutrient data by Zimmerman and Campo (2007) concluded that the relatively small number of sites and presence of wastewater-return flows made it difficult to determine appropriate nutrient criteria for the different ecoregions of the State. Consequently, a range of threshold concentrations for reference 
streams in northeastern Massachusetts were used to develop nutrient threshold-yield curves for each constituent. Sources of information for threshold concentrations differ by constituent and included consideration of TSS effluent limits in the Brockton AWRF permit. Because the selection of the most appropriate threshold concentration was beyond the scope of this study, a range of threshold concentrations obtained by different methods was used to develop "end member" threshold-yield curves (that is, curves based on the least and most stringent selected threshold concentrations). These end members were not meant to represent allowable concentrations for TMDL development; rather they were used only as a basis of comparison to evaluate the magnitude of measured daily yields in the impaired reaches and Taunton River. Although loading to Mount Hope Bay was of interest, threshold concentrations for estuarine ecosystems were not considered for this study.

Three total phosphorus threshold concentrations were selected for consideration in the yield-duration analysis: the 25th percentile concentration for EPA subecoregion 59 streams; the 75th percentile concentration for the two USGS minimally affected reference streams in Massachusetts and New Hampshire; and the "Gold Book" criterion for total phosphorus concentration (U.S. Environmental Protection Agency, 1986). The 25th percentile total phosphorus concentration for subecoregion 59 streams is $0.024 \mathrm{mg} / \mathrm{L}$ (table 7). The 75 th percentile total phosphorus concentration from sampling sites on Black Brook near Manchester, N.H., and the Stillwater River near Sterling, Mass., is $0.021 \mathrm{mg} / \mathrm{L}$ (table 7). Finally, the Gold Book total phosphorus concentration is $0.10 \mathrm{mg} / \mathrm{L}$, which is the highest threshold concentration for total phosphorus used in the study. Total phosphorus threshold concentrations therefore range from 0.021 to $0.10 \mathrm{mg} / \mathrm{L}$, and these two values were used to construct the end-member threshold-yield curves.

Two total nitrogen threshold concentrations were selected for use in the yield-duration analysis: the 25th percentile concentration for EPA subecoregion 59 streams and the 75th percentile concentration for the two USGS minimally affected reference streams in Massachusetts and New Hampshire. The 75th percentile total nitrogen concentration from sampling sites on Black Brook near Manchester, N.H., and the Stillwater River near Sterling, Mass., is $0.48 \mathrm{mg} / \mathrm{L}$, and the 25 th percentile total nitrogen concentration for subecoregion 59 streams is $0.57 \mathrm{mg} / \mathrm{L}$ (table 7). Total nitrogen threshold concentrations therefore range from 0.48 to $0.57 \mathrm{mg} / \mathrm{L}$, and these two values were used to construct the end-member threshold-yield curves.

Studies relating TSS concentrations to ecological effects are not available for the region, although excessive sediment is known to have detrimental effects on fish, invertebrates, and aquatic vegetation by limiting light penetration and covering habitat (U.S. Environmental Protection Agency, 2003). Criteria that are protective of aquatic life generally are considered to be more stringent than criteria for other designated uses. Because criteria from published studies were not available, a range of threshold concentrations was established from different sources. These include dilution of allowable concentration limits for treated effluent specified in the Brockton AWRF 2005 National Pollutant Discharge Elimination System (NPDES) discharge permit (permit no. MA0101010) and an informal MA DEP guidelines for sediment concentration ranges in the region.

Brockton AWRF effluent TSS concentration limits are specified for two seasons (May 1 through October 31 and November 1 through April 30) and three time intervals (average monthly, average weekly, and maximum daily). Maximum daily limits are set higher than average monthly and weekly limits with the expectation that occasional high daily concentrations will be balanced by lower daily concentrations. To establish a low (stringent) threshold concentration for TSS, a dilution factor of 10 was applied to the maximum daily limit of $30 \mathrm{mg} / \mathrm{L}$ for November 1 through April 30, resulting in a threshold concentration of $3 \mathrm{mg} / \mathrm{L}$ (Kimberly Groff, Massachusetts Department of Environmental Protection, written commun., 2011). This low concentration is comparable to the median concentration of $5.3 \mathrm{mg} / \mathrm{L}$ from sampling sites in the impaired-reach areas. The least stringent threshold concentration used in this study was $80 \mathrm{mg} / \mathrm{L}$, which is used as an informal threshold TSS concentration for poor water quality in the region (Kimberly Groff, Massachusetts Department of Environmental Protection, written commun., 2011). TSS threshold concentrations therefore range from 3.0 to $80 \mathrm{mg} / \mathrm{L}$, and these two values were used to construct the end-member threshold-yield curves.

\section{Yield-Duration Plots for Impaired Reaches}

Yield-duration plots for total phosphorus, total nitrogen, and TSS were constructed for each of the impaired reaches in the Taunton River Basin. Impaired reach MA62-32 at the mouth of the Matfield River was represented by two (upper and lower) yield-duration plots because the reach spans two HSPF subbasins and contains numerous sampling sites and confluences with major tributaries. Reaches MA62-53 and MA62-54 on the Segreganset River were treated as a single impaired reach because MA62-54, although designated as a separate impaired reach, is only a short segment on the downstream end of MA62-53. Also, sampling site MHB C is about 1,000 ft downstream from the end of MA62-54 but was used in the analysis to represent yields from MA62-53/54. Yield-duration plots were not developed for MA62-14 (Robinson Brook) and MA62-42 (unnamed tributary to Cedar Swamp River) because data were not available or only one or two samples were collected from the reach. In addition, total nitrogen data were not available for MA62-33 (Shumatuscacant River). Estimated daily loads used to calculate yields are summarized in table 8 , in back of report. 


\section{Total Phosphorus}

Total phosphorus yields in the impaired reaches typically were greater than threshold yields based on the 75th percentile total phosphorus concentration $(0.021 \mathrm{mg} / \mathrm{L})$ in the USGS reference streams but less than threshold yields based on the EPA Gold Book concentration ( $0.1 \mathrm{mg} / \mathrm{L})$ (fig. 7). The highest total phosphorus yields were observed in reaches downstream from the Brockton AWRF outfall (MA62-06, lower Salisbury Plain River; and MA62-32, upper and lower Matfield River), with yields ranging from about 0.2 to 7 pounds per square mile per day $\left(\mathrm{lb} / \mathrm{mi}^{2} / \mathrm{d}\right)$ for lower flows (figs. $7 \mathrm{~A}-\mathrm{C}$ ). These high yields were because of flow augmentation (refer to the Water Use section and appendix 1 for detailed discussions of flow augmentation) and high phosphorus concentrations in treated effluent. The measured yields in these reaches also were substantially higher than threshold yields based on the EPA Gold Book concentration. High measured yields relative to threshold yields indicate that the outfall was a major point source for total phosphorus for the period 1999-2006 when these data were collected (that is, high yields are not just because of higher flows resulting from discharge of municipal wastewater because these flows are incorporated into the threshold-yield curve). Although there is considerable scatter in the measured yields, they exceeded threshold yields across a fairly wide range in flows (not just low flows), reflecting the large augmentation of streamflow by wastewater at this site, and possibly that other processes such as resuspension of particulate phosphorous are important at higher flows. The latter explanation is consistent with observations of substantial algal and macrophyte growth in the streambed downstream from the outfall.

The effect of the Brockton AWRF outfall for the period 1999-2006 also can be seen by comparing the yield-duration plots for the Salisbury Plain River upstream (impaired reach MA62-05; fig. 7D) and downstream (impaired reach MA6206; fig. 7A) from the outfall. Drainage areas to both impaired reaches are about 65 percent developed (table 6), but yields are substantially higher downstream from the outfall. The lower part of the Matfield River receives flow from Beaver Brook, Meadow Brook, and the Satucket River, which contain impaired reaches MA62-09, MA62-38, and MA62-33 in their respective drainage areas, but due mainly to lower instream phosphorus concentrations, total phosphorous yields from these streams are less than yields from the Salisbury Plain River. Thus, discharge of municipal wastewater had a dominant effect on the entire length of the Matfield River (figs. 7B, C), the mouth of which is about 6 mi below the outfall. On the basis of reductions of total phosphorus concentrations in treated effluent in response to plant upgrades that occurred after most of these data were collected, discharge of municipal wastewater from the Brockton AWRF currently may have a smaller effect on total phosphorus yield.

In the impaired reaches not affected by the Brockton AWRF outfall, measured yields were lower than in reaches below the outfall and typically did not exceed EPA Gold Book threshold yields (figs. 7D-I). Yields were typically less than $0.2 \mathrm{lb} / \mathrm{mi}^{2} / \mathrm{d}$ for lower flows. Of these reaches, yields were higher for the reaches with larger percentages of developed land use in their drainage areas, such as MA62-07 (Trout Brook), MA62-05 (upper Salisbury Plain River), and MA6208 (Salisbury Brook), suggesting that diffuse sources associated with development contribute to total phosphorus loading in these watersheds. The Trout Brook drainage area is small $(4,448$ acres) and is mainly within Brockton; consequently, the Trout Brook drainage area is 70.6 percent developed, the highest percentage of developed land of all the impaired reaches in the basin (table 6). The drainage areas to the Salisbury Plain River and Salisbury Brook also contain parts of Brockton (66.1 and 58.6 percent developed, respectively). Although there is scatter in the data, measured total phosphorus yields in these reaches were relatively high, equaling or slightly exceeding EPA Gold Book threshold yields over a wide range in flows (figs. 7D-F). In contrast, Beaver Brook, Meadow Brook, Shumatuscacant River, Rumford River, and Segreganset River have relatively small percentages of developed land in their drainage areas (table 6) and correspondingly lower absolute measured yields in the impaired reaches (figs. 7G-K). Measured yields infrequently equaled or exceeded EPA Gold Book threshold yields in these reaches.

In most of the impaired reaches not affected by a point source, measured yields exceeded the threshold-yield curve over a wide range of flows. This may indicate that multiple processes, such as surface runoff from effective impervious and pervious areas adjacent to streams, streambank erosion, and resuspension of bed sediment and algal and macrophyte biomass, contribute to nonpoint phosphorus loading in these reaches.

Although total phosphorous yields may be related to the extent of development or existence of point sources such as municipal wastewater discharge in total drainage areas, on a smaller scale, such as along the length of an impaired reach, spatial patterns in daily loads were less evident. For example, impaired reach MA62-08 on Salisbury Brook contains five evenly-spaced sampling sites along the length of the reach (fig. 6A). A comparison of measured yields to threshold yields does not indicate that a particular location along the reach has substantially higher or lower yields than any other, or that a consistent trend in the departure of the measured yield from the threshold yield was present in the upstream or downstream direction. Salisbury Brook is representative of most of the impaired reaches in the basin. The absence of spatial patterns in yield along most of the impaired reaches may be because of a lack of a significant point source or tributary input along the reach or spatially homogeneous land use (and phosphorus concentration in runoff) in the drainage area to the reach. Alternatively, because samples in this dataset were collected over a period of years by different organizations under different weather and flow conditions, subtle patterns may have been present but were not evident. 
A. Impaired Reach MA62-06, lower Salisbury Plain River

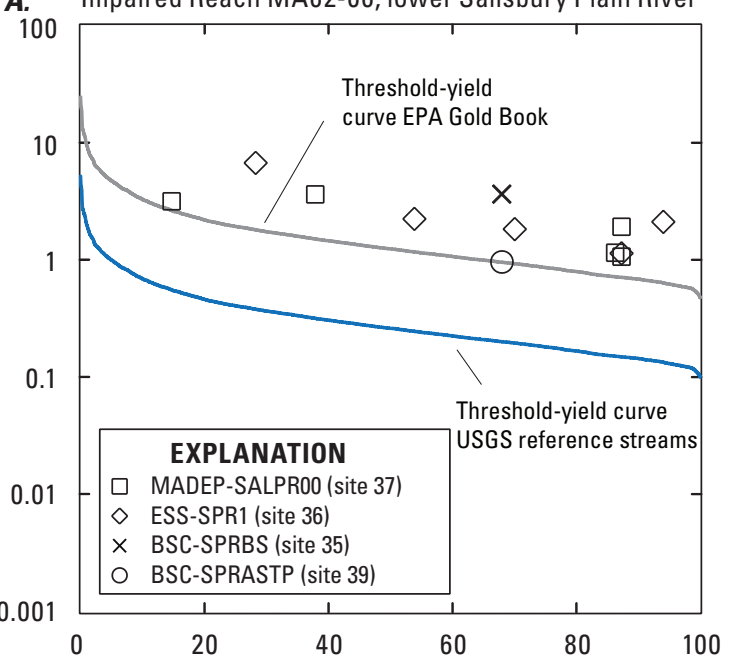

व

C. Impaired Reach MA62-32, lower Matfield River 0.001

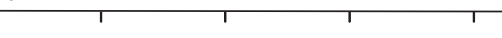$$
10
$$

1<smiles>C1CCCCC1</smiles>

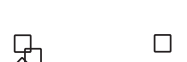

0.1

1

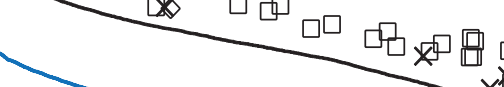

\section{EXPLANATION}

$\square$ BSC-MRHS (site 17)

$\diamond$ MADEP-MATROO (site 16)

$\times$ ESS-MR1 (site 15)

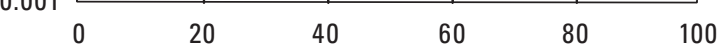

E. Impaired Reach MA62-07, Trout Brook

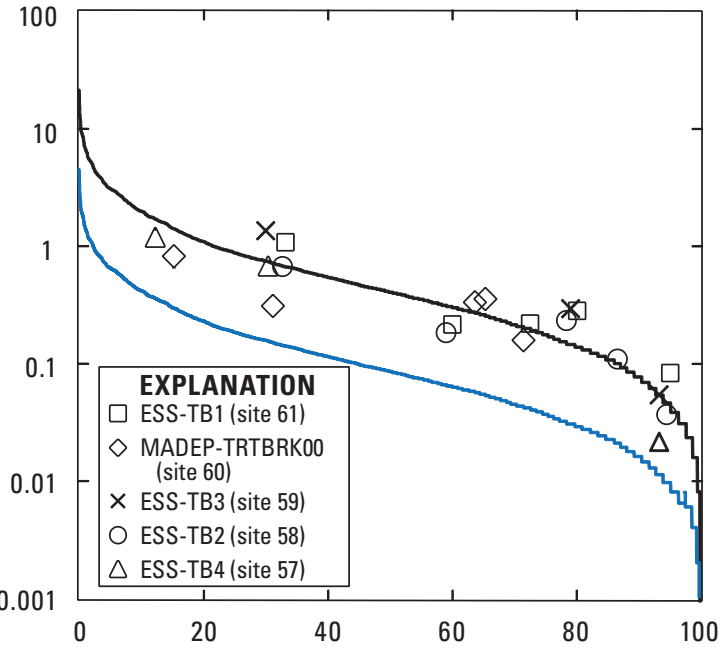

B. Impaired Reach MA62-32, upper Matfield River

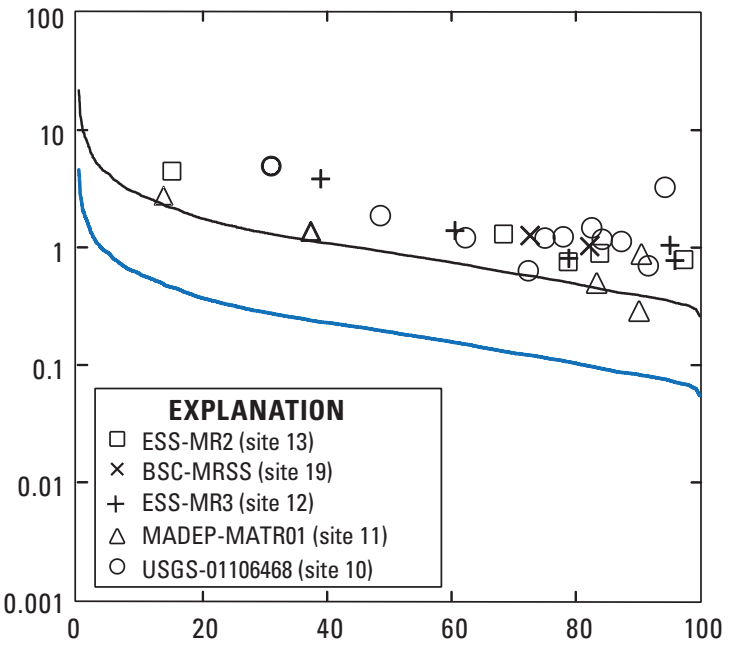

D. Impaired Reach MA62-05, upper Salisbury Plain River

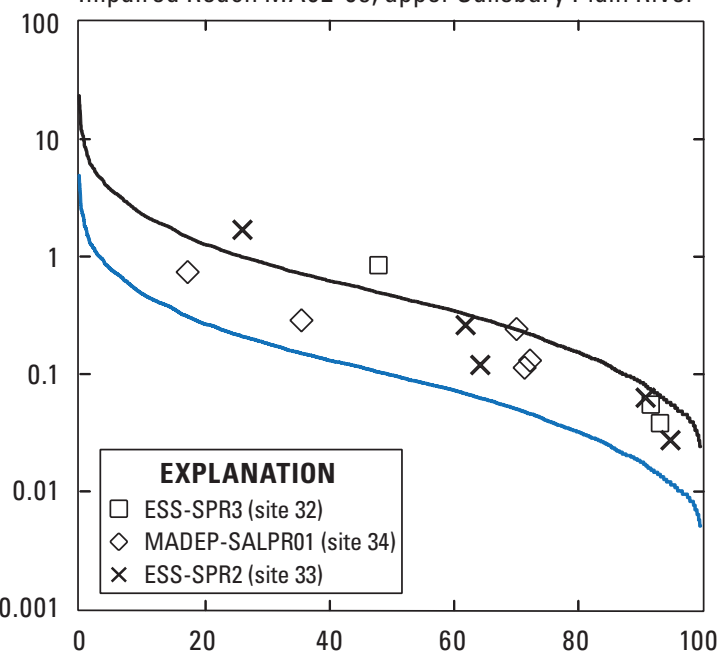

F. Impaired Reach MA62-08, Salisbury Brook

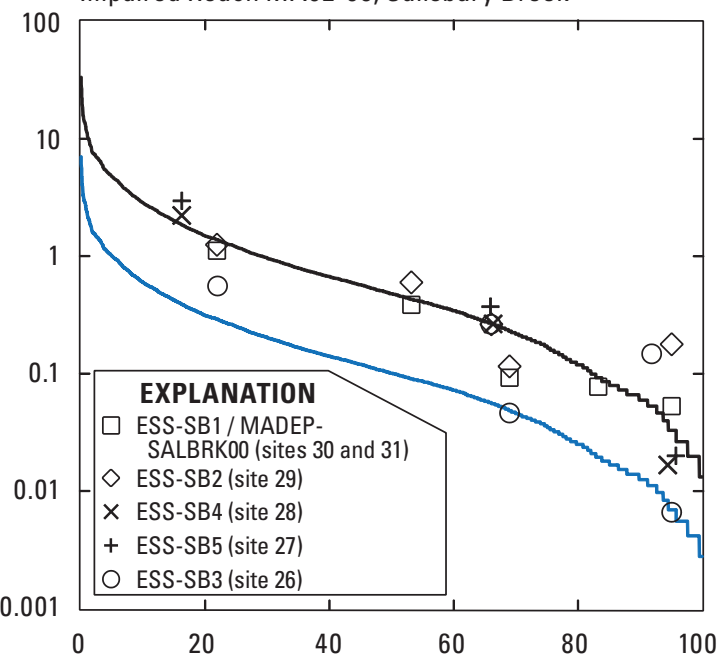

Exceedance probability

Figure 7. Total phosphorus yield-duration plots for impaired reaches $A$, MA62-06 (lower Salisbury Plain River); $B$, MA62-32 (upper Matfield River); C, MA62-32 (lower Matfield River); D, MA62-05 (upper Salisbury Plain River); E, MA62-07 (Trout Brook); F, MA62-08 (Salisbury Brook); G, MA62-09 (Beaver Brook); H, MA62-38 (Meadow Brook); I, MA62-33 (Shumatuscacant River); J, MA32-39 (Rumford River); and K, MA62-53/54 (Segreganset River) in the Taunton River Basin. Lower line in each graph is the threshold-yield curve based on the 75th percentile total phosphorus concentration for U.S. Geological Survey (USGS) reference streams. Upper line is the thresholdyield curve based on the U.S. Environmental Protection Agency (EPA) “Gold Book" total phosphorus concentration. 


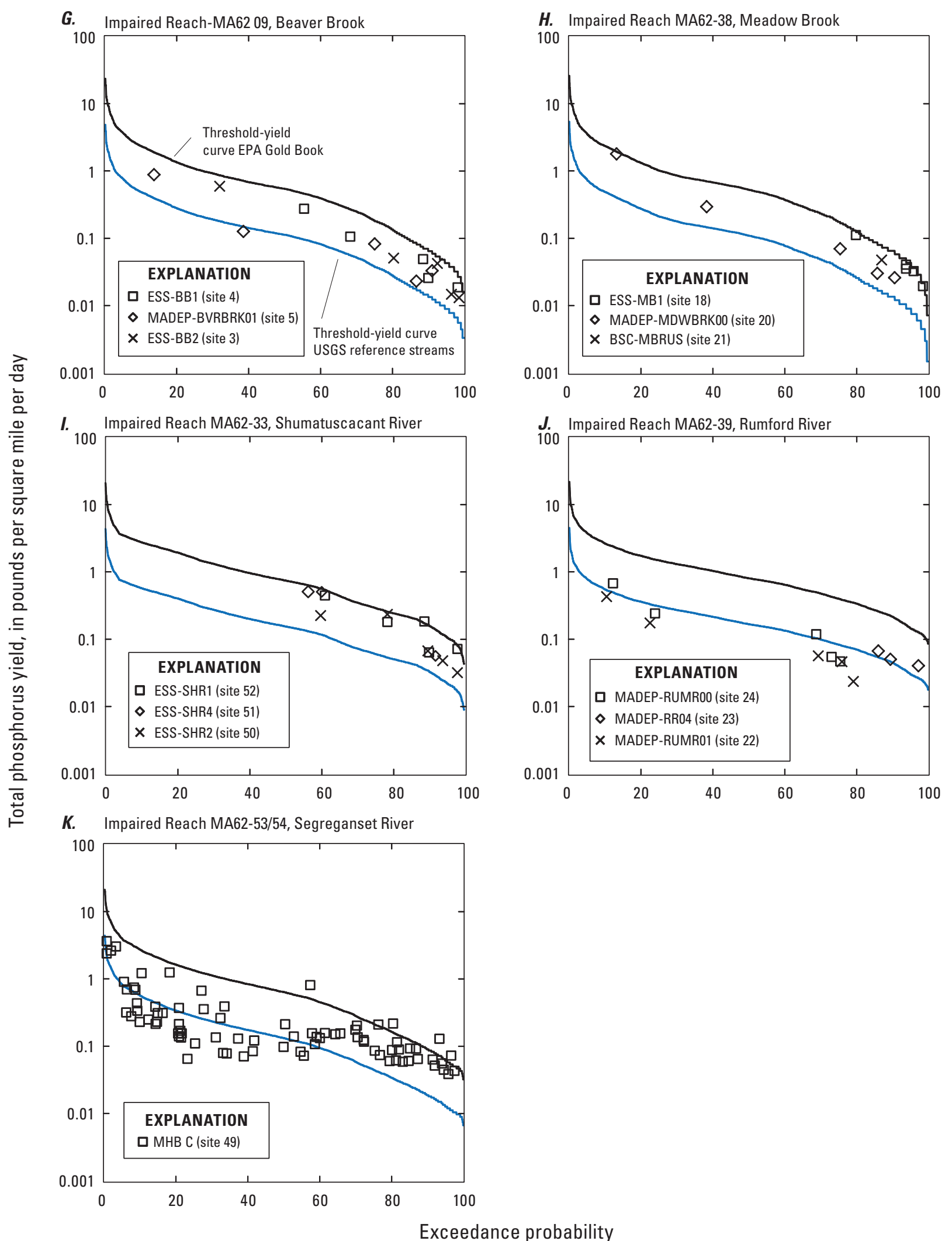

Figure 7. Total phosphorus yield-duration plots for impaired reaches A, MA62-06 (lower Salisbury Plain River); B, MA62-32 (upper Matfield River); C, MA62-32 (lower Matfield River); D, MA62-05 (upper Salisbury Plain River); E, MA62-07 (Trout Brook); F, MA62-08 (Salisbury Brook); G, MA62-09 (Beaver Brook); H, MA62-38 (Meadow Brook); I, MA62-33 (Shumatuscacant River); J, MA32-39 (Rumford River); and K, MA62-53/54 (Segreganset River) in the Taunton River Basin. Lower line in each graph is the threshold-yield curve based on the 75th percentile total phosphorus concentration for U.S. Geological Survey (USGS) reference streams. Upper line is the thresholdyield curve based on the U.S. Environmental Protection Agency (EPA) "Gold Book" total phosphorus concentration.-Continued 


\section{Total Nitrogen}

Total nitrogen yields in the impaired reaches typically were greater than threshold yields based on the 75 th percentile total nitrogen concentration $(0.48 \mathrm{mg} / \mathrm{L})$ in the USGS reference streams and the 25 th percentile concentration $(0.57 \mathrm{mg} / \mathrm{L})$ for EPA subecoregion 59 streams (fig. 8). In comparison to total phosphorus, relatively few sites were sampled for total nitrogen. Total nitrogen data were obtained from only one sampling site in most of the impaired reaches. The paucity of total nitrogen data makes it more difficult to relate yield to the extent of development in the drainage area, evaluate spatial differences in yield within reaches, or determine differences between measured and threshold yields across the full range of flows. However, based on the available data, patterns appear to be similar to those for total phosphorus.

The highest total nitrogen yields were observed in reaches downstream from the Brockton AWRF outfall (MA62-06, lower Salisbury Plain River; and MA62-32, upper and lower Matfield River), with yields up to $100 \mathrm{lbs} / \mathrm{mi}^{2} / \mathrm{d}$ for lower flows (figs. 8A-C). Similar to total phosphorus, these high absolute yields were because of flow augmentation and high nitrogen concentrations in treated effluent. The measured yields in these reaches also were substantially higher than threshold yields. High observed yields relative to threshold yields indicate that the outfall was a major point source for nitrogen as well as for phosphorus for the period 1999-2006 when these data were collected. In contrast to phosphorus, measured total nitrogen yields appeared to exceed the upper threshold-yield curve by a greater amount under low-flow conditions, perhaps reflecting the higher proportion of municipal wastewater in streamflow at lower flows in combination with contributions from base-flow discharge.

Measured total nitrogen yields were lower in the impaired reaches not affected by the Brockton AWRF outfall than in the reaches downstream from the outfall and generally did not greatly exceed the threshold-yield curve (figs. 8D-H). Yields in these reaches were as high as about $5 \mathrm{lb} / \mathrm{mi}^{2} / \mathrm{d}$ for lower flows. Of these reaches, yields appeared to be higher for the reaches with larger percentages of developed land use in their drainage areas, such as MA62-07 (Trout Brook), MA62-08 (Salisbury Brook), and MA62-05 (Salisbury Plain River), suggesting that diffuse sources associated with development contribute to total nitrogen loading in these watersheds.

Diffuse sources for total nitrogen generally are similar to those for total phosphorus. A major difference is the higher mobility of nitrogen (mainly as nitrate) in soil and groundwater. Consequently, in comparison to total phosphorus, it is more likely that nitrogen from fertilizer and septic systems in residential areas will reach groundwater (Lapham, 1988) and then discharge to streams as base flow under low-flow conditions. Groundwater discharge as base flow is the main source of water to streams under low-flow conditions. In contrast to phosphorus, elevated nitrogen loads under low-flow conditions can be indicative of nonpoint sources in addition to direct discharge from a point source.

\section{Total Suspended Solids}

Total suspended solid yields in the impaired reaches typically were greater than threshold yields based on a tenfold dilution of the Brockton AWRF winter daily maximum effluent limit of $30 \mathrm{mg} / \mathrm{L} \mathrm{(3} \mathrm{mg/L)} \mathrm{but} \mathrm{less} \mathrm{than} \mathrm{the} \mathrm{informal} \mathrm{MA}$ DEP guideline ( $80 \mathrm{mg} / \mathrm{L}$ ) (fig. 9). Although there is considerable scatter in the measured TSS yields, patterns appear to be similar to those for total phosphorus and total nitrogen. One limitation of the TSS dataset is relatively few samples were collected during storms and high-flow conditions (that is, flows equaled or exceeded less than 15 percent of the time), when processes such as streambank erosion or runoff from impervious surfaces would be expected to produce TSS yields that are high relative to threshold yields. Yields from the few samples collected under high-flow conditions do not indicate that such processes produce excessive TSS yields in the impaired reaches.

TSS yields were highest in reaches downstream from the Brockton AWRF outfall (MA62-06, lower Salisbury Plain River; and MA62-32, upper and lower Matfield River) (figs. 9A-C). However, in contrast to the nutrient data, discharge from the Brockton AWRF outfall did not produce TSS yields that were elevated relative to the threshold-yield curve. Measured TSS yields relative to threshold yields were similar upstream and downstream from the outfall (figs. 9A, D), suggesting that TSS concentrations in the treated effluent were not substantially higher than background concentrations in the stream when these samples were collected. However, the absolute magnitude of measured TSS yields downstream from the outfall are higher at midrange to lower flows because of flow augmentation.

In addition, similar to the nutrient data, measured TSS yields were lower in the impaired reaches not affected by the Brockton AWRF outfall, and of these reaches, yields appeared to be highest in the reaches with high percentages of developed land use in their drainage areas, such as MA62-07 (Trout Brook), MA62-08 (Salisbury Brook), and MA62-05 (upper Salisbury Plain River).

\section{Yield-Duration Plots for Taunton River Reaches}

Available flow and water-quality data were used to evaluate nutrient delivery from the Taunton River to Mount Hope Bay. Yield-duration plots were developed for Taunton River sampling sites at the USGS streamgage at Titicut Street, Bridgewater (station no. 011008000), and near the Berkley Bridge, Dighton/Berkley line (site 414949071065301). The tidally influenced Berkley Bridge site is approximately $19 \mathrm{mi}$ downstream from the Titicut Street site and $9 \mathrm{mi}$ from the mouth of the basin. The Titicut Street site is approximately $3.7 \mathrm{mi}$ upstream from the upper limit of tidal influence. Waterquality data were collected over an 11-year period (19972008). Flow-duration curves are based on 10 years (19972006) and approximately 4 years (2006-9) of measured daily mean streamflow at the Titicut Street and Berkley Bridge sites, respectively. Flows for the Berkley Bridge site are the sum of 
upstream streamgages adjusted for drainage-area differences between the streamgages and sampling site as described in the Streamflow Measurements section of the report.

Total phosphorus yields at both sites were near or slightly above EPA Gold Book threshold yields (fig. 10A). Differences between measured and threshold yields were roughly constant for all exceedance probabilities. As discussed above, this pattern indicates there was no dominant source (such as a point discharge) that increased yields for a specific range of exceedance probabilities. Rather, the data indicate that total phosphorus concentrations remained fairly constant over a wide range of flows. Available data indicate that differences in total phosphorus yields between the upstream and downstream sites were minor.

Total nitrogen yields generally were above threshold yields based on the 25 th percentile concentration $(0.57 \mathrm{mg} / \mathrm{L})$ for EPA subecoregion 59 streams at both sampling sites (fig. 10B). At the Titicut Street site, measured yields were substantially higher than threshold yields at lower flows. This may reflect contributions from point sources in the drainage area (the wastewater-impacted Matfield River discharges to the Taunton River approximately $9 \mathrm{mi}$ upstream from the sampling site), and diffuse sources (for example, septic systems) that increase nitrogen concentrations in groundwater (Lapham, 1988). Available data also indicate that differences in total nitrogen yields between the upstream and downstream sites were minor.

\section{SPARROW-Predicted Sources of Total Nitrogen and Phosphorus Loads}

The 2002 Northeast and Mid-Atlantic SPARROW (SPAtially Referenced Regressions of Watershed Attributes) water-quality model (Moore and others, 2011) was used to identify and estimate the magnitude of total nitrogen and phosphorus sources in total drainage areas to the impaired reaches and the main stem of the Taunton River at two locations, including the mouth of the river at New Bedford, Mass. SPARROW is a regional, statistical model that relates nutrient loads in streams to upstream sources and land-use characteristics and can be used to make predictions for streams that do not have nutrient-load data. The model contains more than 193,000 catchments, with an average size of 570 acres $\left(2.3 \mathrm{~km}^{2}\right)$, and was calibrated with data from 363 nitrogen and 457 phosphorus measurement sites (Moore and others, 2011). Median drainage areas of the measurement sites were 101,807 acres for nitrogen and 107,243 acres for phosphorus. Physical watershed characteristics considered in the regression include drainage area, land use, streamflow, time-of-travel, stream density, percent wetlands, slope of land surface, and soil permeability. Statistically significant source variables in the total nitrogen model include: municipal-wastewater discharge, atmospheric deposition, developed land area, fertilizer applied to agricultural land (corn and soybean), fertilizer applied to other crops, and manure from livestock production. Statistically significant source variables in the total phosphorus model include: municipal-wastewater discharge, forested land area, developed land area, fertilizer applied to agricultural land (corn and soybean), fertilizer applied to other crops, and manure from livestock production. Land areas are surrogates for nonpoint sources within those areas. In-stream nutrient losses were not statistically significant for larger streams (mean annual flows greater than about $100 \mathrm{ft}^{3} / \mathrm{s}$ ). The model predicts mean annual loads based on long-term streamflow and water-quality data. Predicted loads represent nutrient source conditions for the year 2002.

Although the discretization of the SPARROW model and delineation of the impaired reaches did not coincide in every instance, it was possible to estimate distribution of total nitrogen sources in drainage areas to all impaired reaches (table 10). For total phosphorus, data were not available for drainage areas to four impaired reaches (MA62-42, MA6207, MA62-38 and MA62-14) (table 10). Also, MA62-05 (Salisbury Plain River above Brockton AWRF outfall) was not discretized as a separate reach in SPARROW. Consequently, table 10 shows source loads for the total drainage area to the mouth of the Salisbury Plain River, including the municipal point source. Results shown in table 10 are "delivered loads" that account for in-stream transport and loss. Consistent with the yield-duration analysis, SPARROW results indicate that the municipal point source (that is, the Brockton AWRF outfall) was the major source for constituent loads in the impaired-reach areas for the year 2002. In the reaches immediately downstream from the outfall (MA62-06 and MA62-32), the point source accounted for about 75 percent of the annual total nitrogen load and 93 percent of the annual total phosphorus load. Municipal point sources from multiple facilities accounted for most of the load in the main stem of the Taunton River (table 10). At the mouth of the Taunton River, point sources accounted for about 76 and 46 percent of the delivered loads of total phosphorus and total nitrogen, respectively.

For similarly sized watersheds, total delivered loads were lower in watersheds without point sources compared to those with point sources. In the absence of municipal point sources, the diffuse sources associated with developed land accounted for most of the delivered nutrient loads to the impaired reaches (table 10). For both constituents, sources associated with agricultural and forested land were relatively unimportant in developed watersheds but contributed appreciably to the total delivered load in less developed watersheds. For example, forested land accounted for 27 percent of the total phosphorus load in the Segreganset River (MA62-53/54), and combined agricultural fertilizer and manure sources accounted for 32 percent of the total nitrogen load to the unnamed tributary to Cedar Swamp River (MA62-42). Atmospheric deposition was an important source for total nitrogen, accounting for up to 31 percent of the load to the impaired reaches (MA6253/54), and 11 percent of the load to the mouth of the Taunton River (table 10). In the main stem, developed land also was an important source of total nitrogen and phosphorus, accounting for 32 and 15 percent, respectively, of the loads delivered to Mount Hope Bay. 
A. Impaired Reach MA62-06, lower Salisbury Plain River

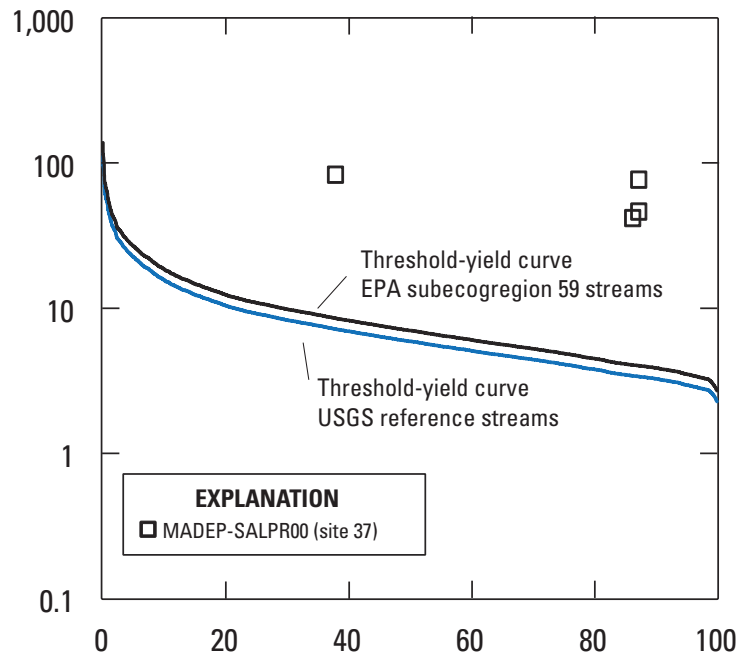

C. Impaired Reach MA62-32, lower Matfield River

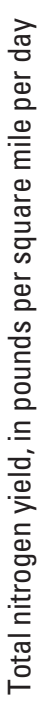

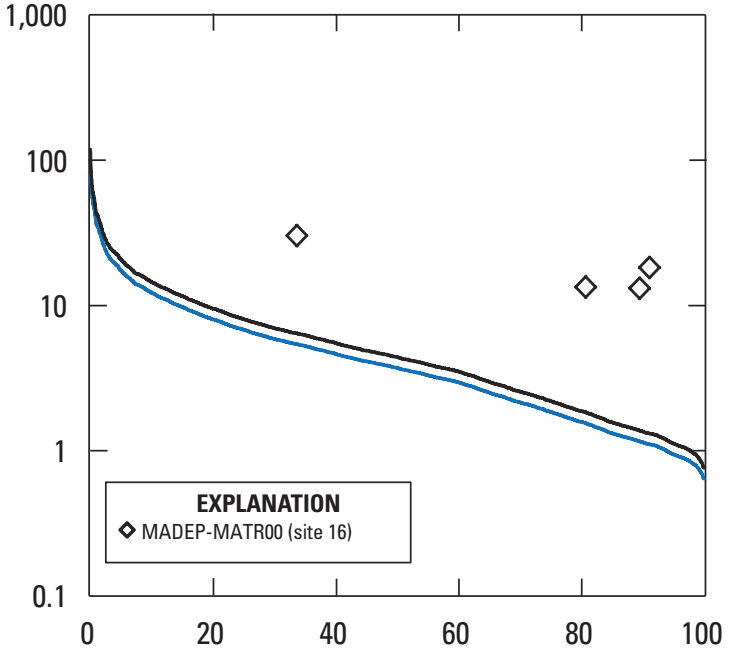

E. Impaired Reach MA62-07, Trout Brook

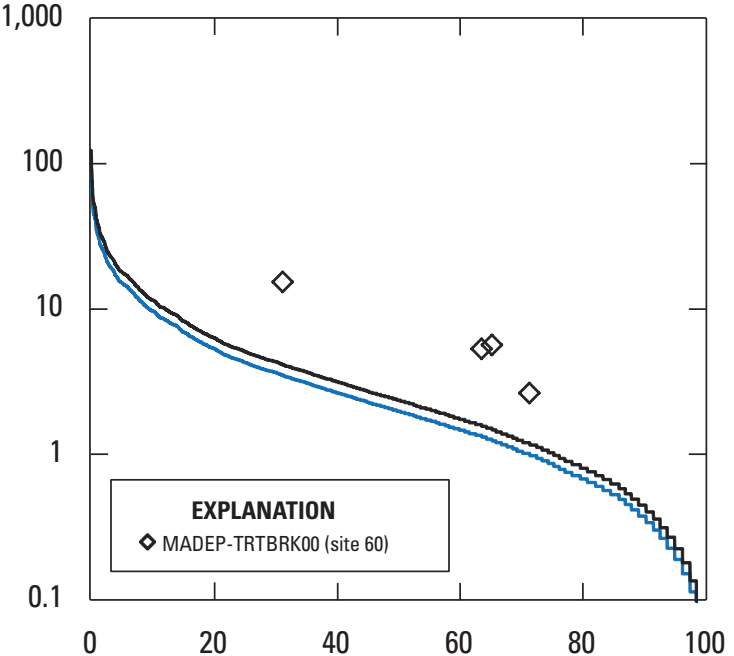

B. Impaired Reach MA62 32, upper Matfield River

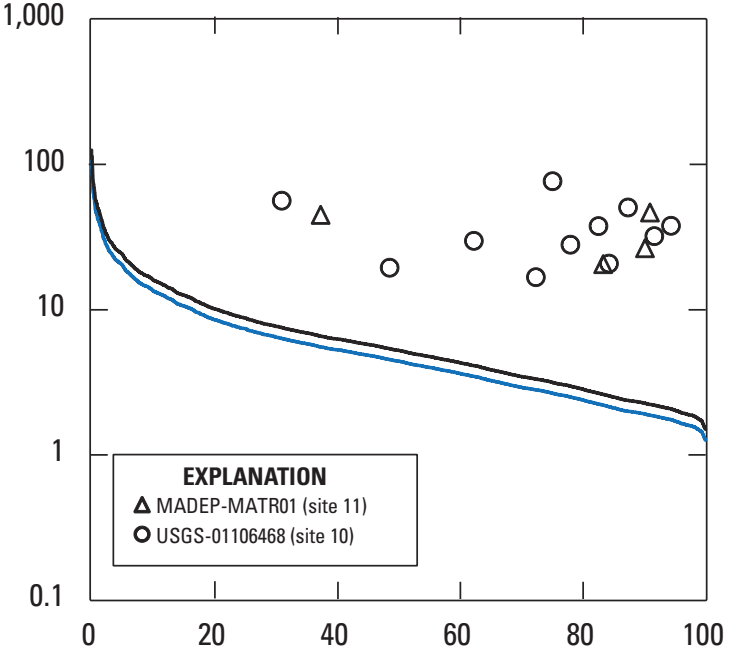

D. Impaired Reach MA62-05, upper Salisbury Plain River

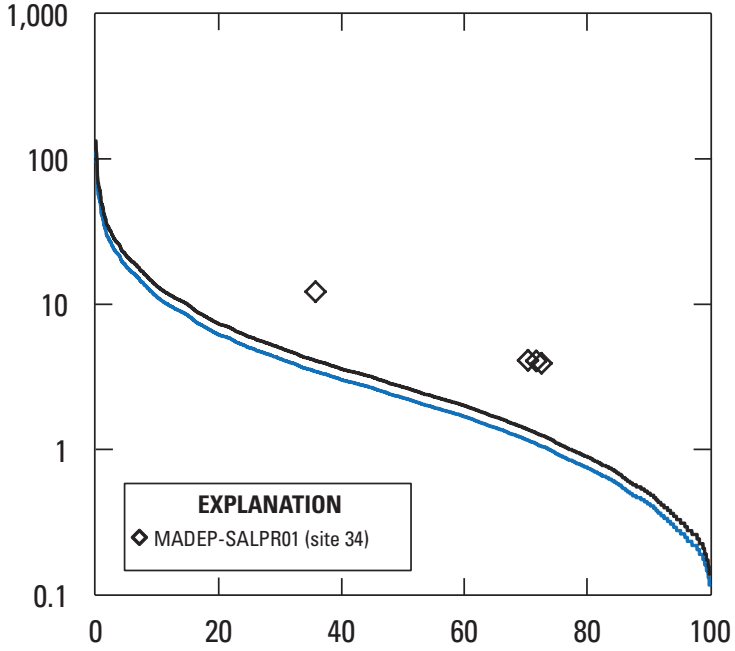

F. Impaired Reach MA62-08, Salisbury Brook

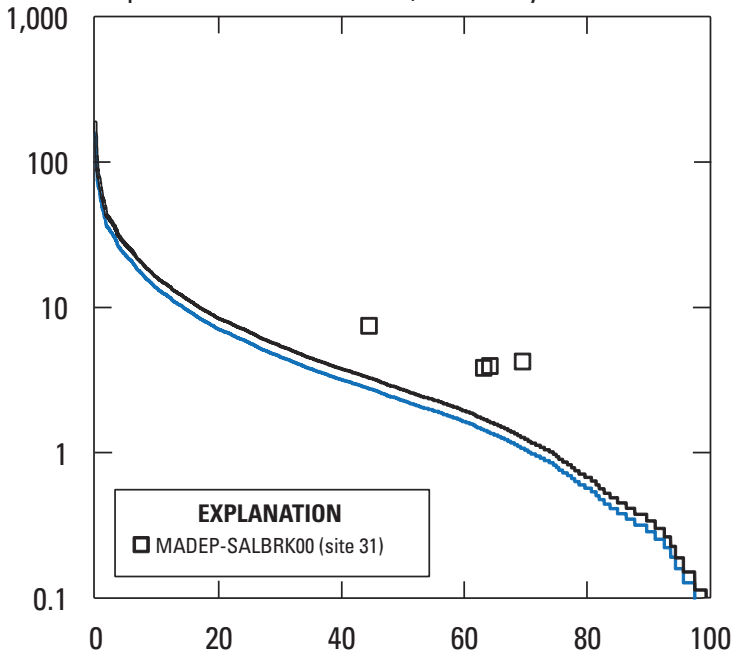

Exceedance probability

Figure 8. Total nitrogen yield-duration plots for impaired reaches $A$, MA62-06 (lower Salisbury Plain River); $B$, MA62-32 (upper Matfield River); C, MA62-32 (lower Matfield River); D, MA62-05 (upper Salisbury Plain River); E, MA62-07 (Trout Brook); F, MA62-08 (Salisbury Brook); G, MA62-09 (Beaver Brook); H, MA62-38 (Meadow Brook); I, MA32-39 (Rumford River); and J, MA62-53/54 (Segreganset River) in the Taunton River Basin. Lower line in each graph is the threshold-yield curve based on the 75th percentile total nitrogen concentration for U.S. Geological Survey (USGS) reference streams. Upper line is the threshold-yield curve based on the 25th percentile total nitrogen concentration for U.S. Environmental Protection Agency (EPA) subecoregion 59 streams. 
G. Impaired Reach MA62-09, Beaver Brook
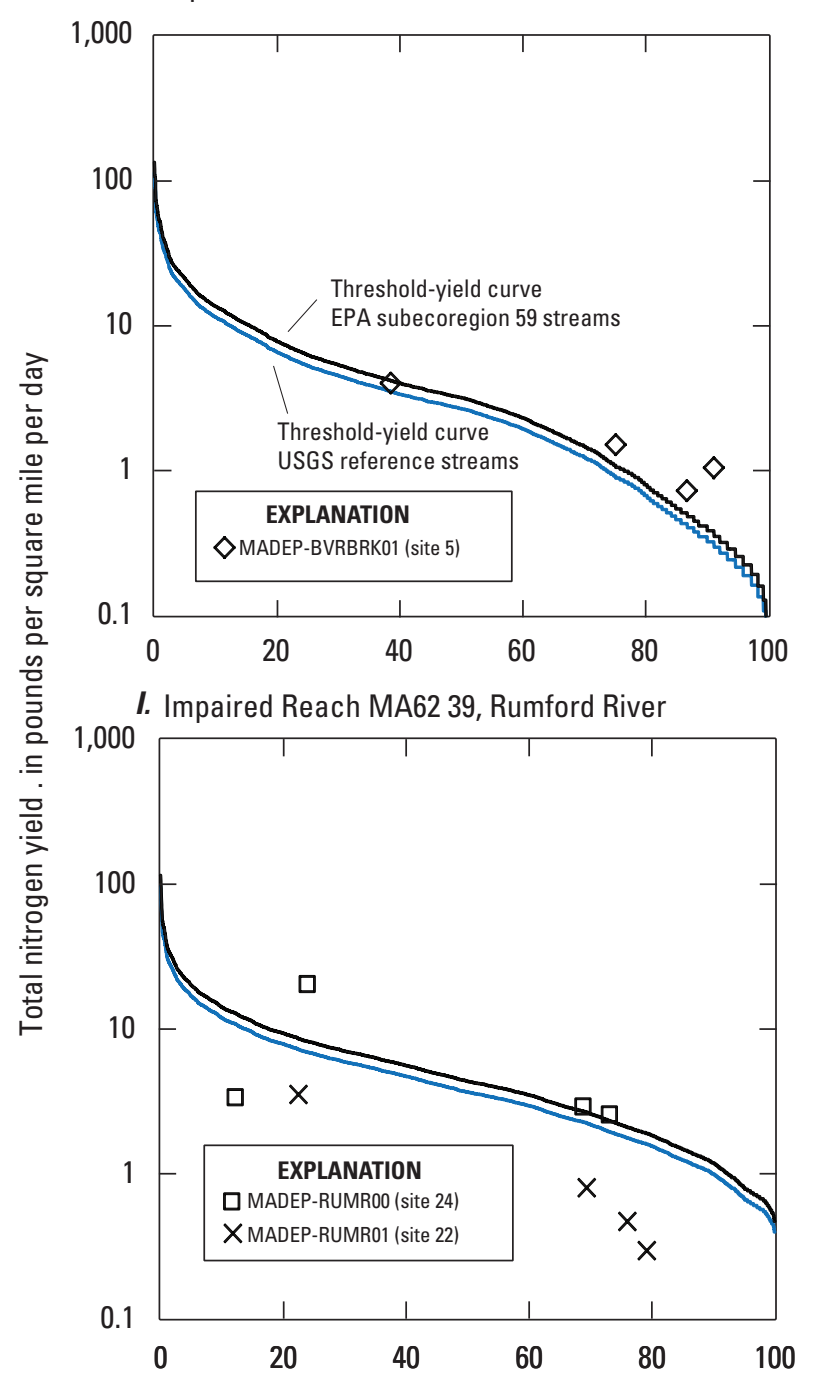

H. Impaired Reach MA62-38, Meadow Brook

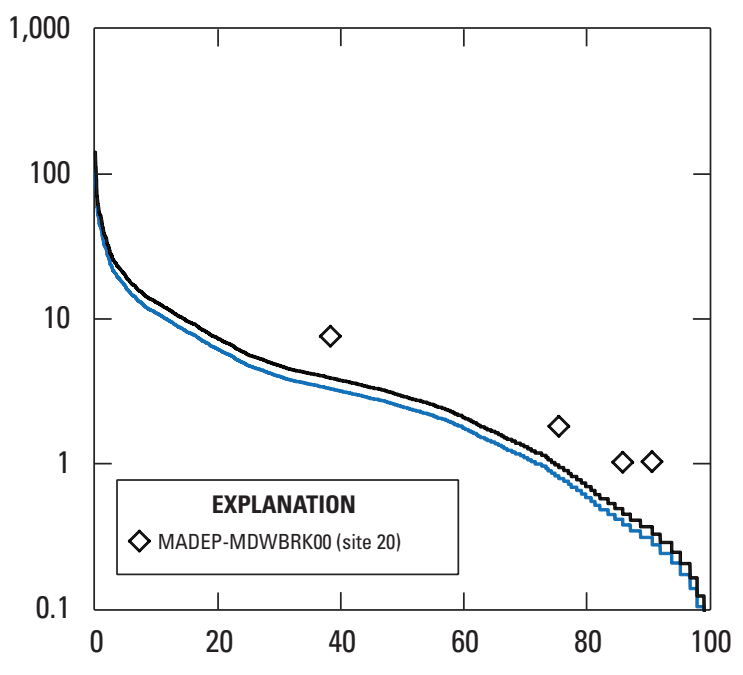

J. Impaired Reach MA62-53/54, Segreganset River

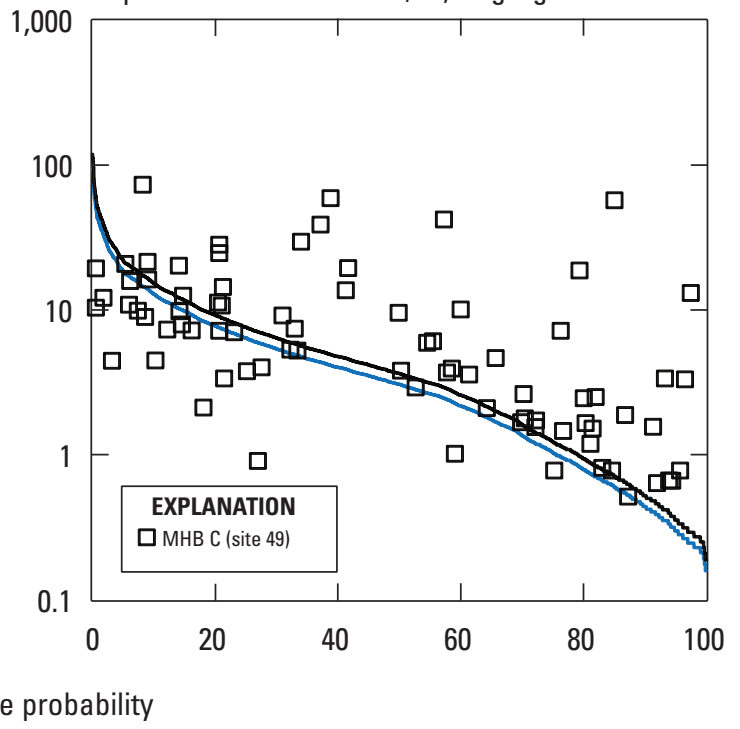

Figure 8. Total nitrogen yield-duration plots for impaired reaches $A$, MA62-06 (lower Salisbury Plain River); $B$, MA62-32 (upper Matfield River); C, MA62-32 (lower Matfield River); D, MA62-05 (upper Salisbury Plain River); E, MA62-07 (Trout Brook); F, MA62-08 (Salisbury Brook); G, MA62-09 (Beaver Brook); H, MA62-38 (Meadow Brook); I, MA32-39 (Rumford River); and J, MA62-53/54 (Segreganset River) in the Taunton River Basin. Lower line in each graph is the threshold-yield curve based on the 75th percentile total nitrogen concentration for U.S. Geological Survey (USGS) reference streams. Upper line is the threshold-yield curve based on the 25th percentile total nitrogen concentration for U.S. Environmental Protection Agency (EPA) subecoregion 59 streams.-Continued 

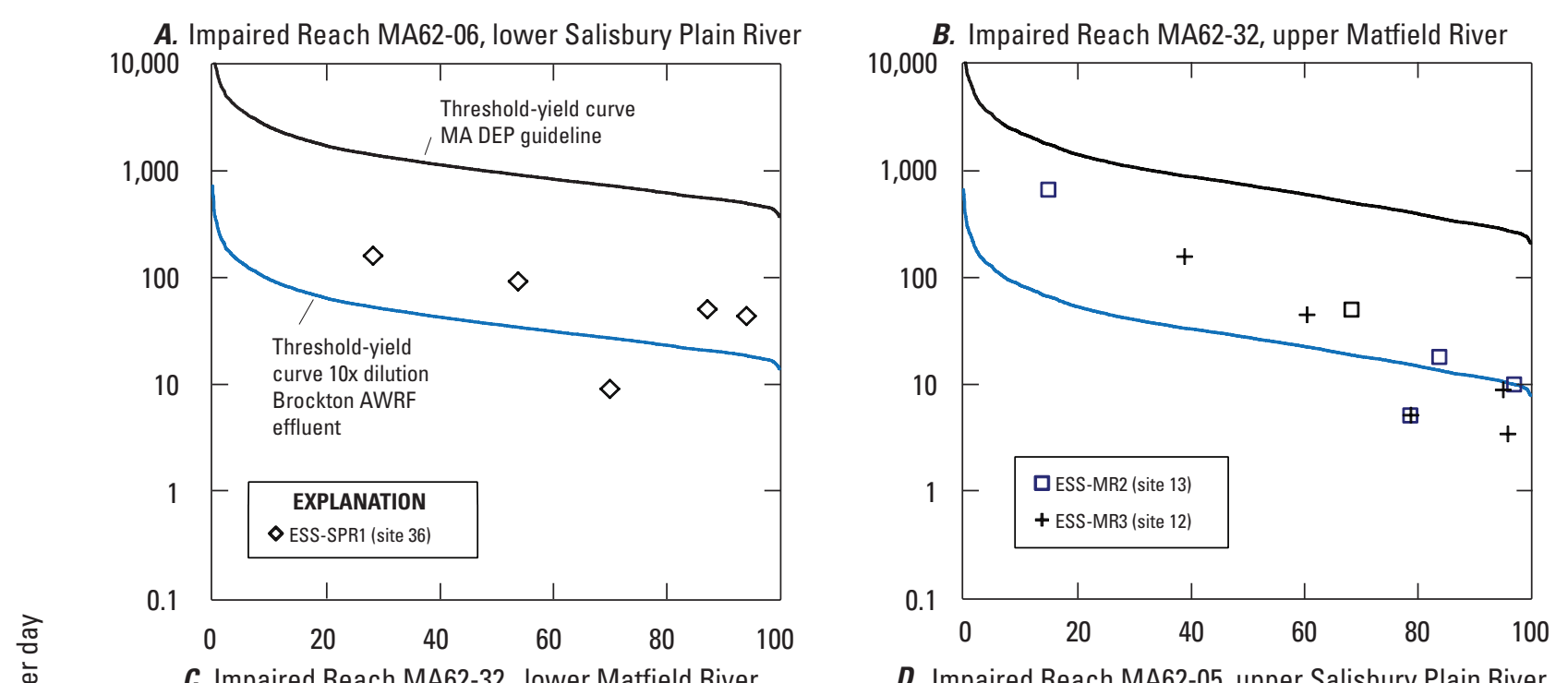

$\cong \quad$ C. Impaired Reach MA62-32, lower Matfield River

D. Impaired Reach MA62-05, upper Salisbury Plain River
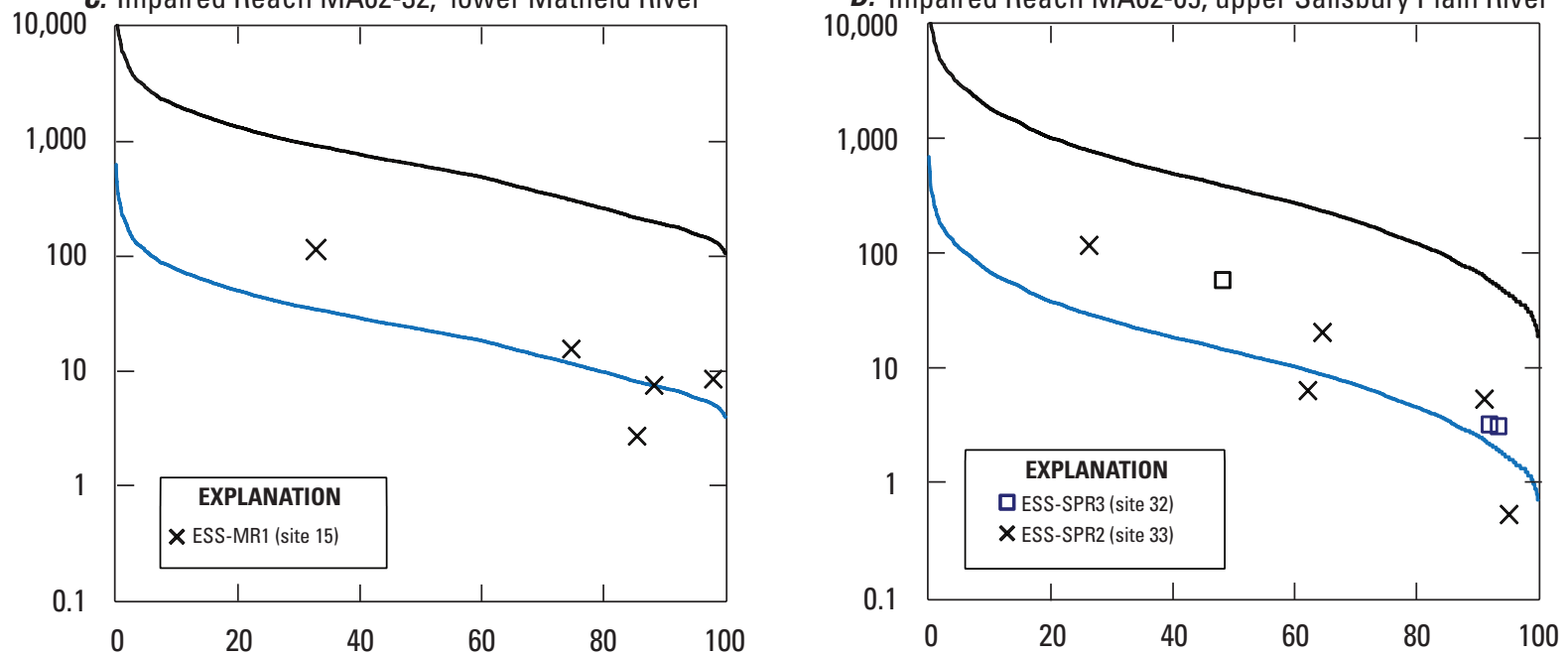

E. Impaired Reach MA62-07, Trout Brook

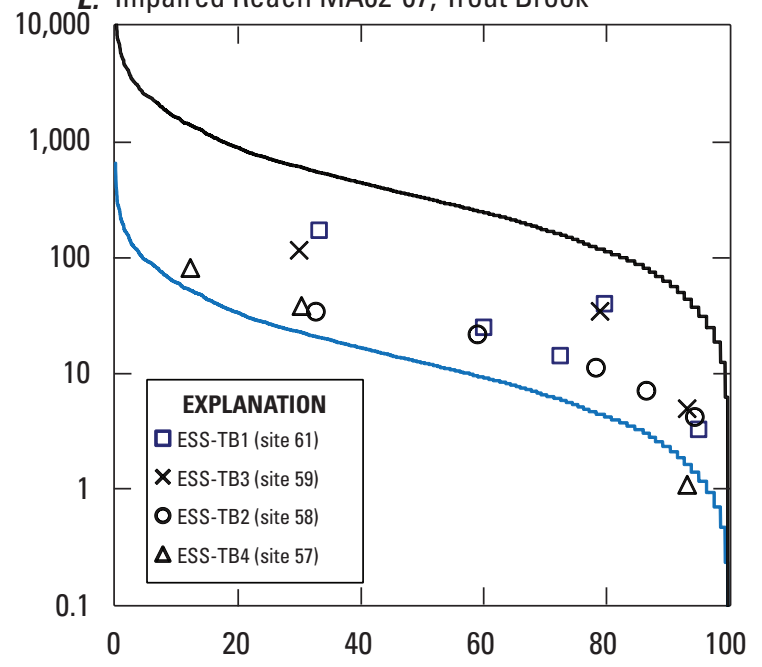

F. Impaired Reach MA62-08, Salisbury Brook

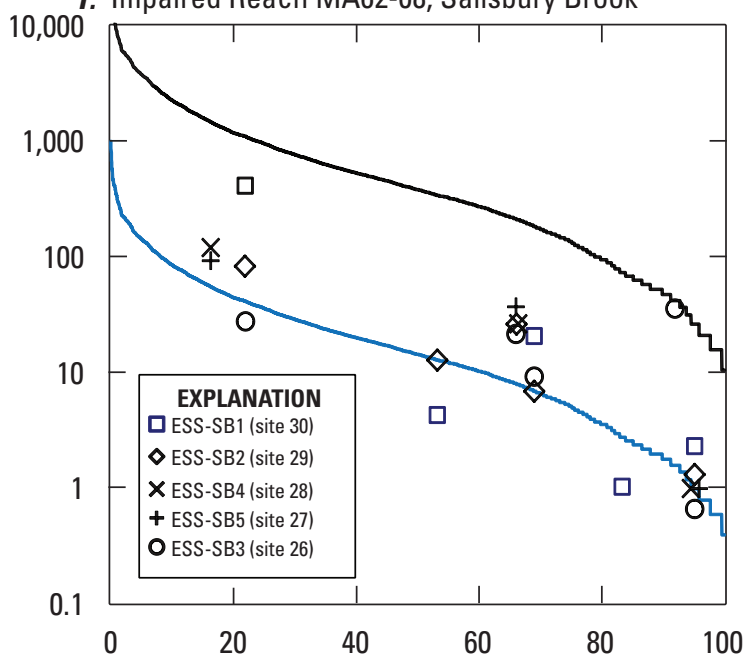

Exceedance probability

Figure 9. Total suspended solids yield-duration plots for impaired reaches $A$, MA62-06 (lower Salisbury Plain River); $B$, MA62-32 (upper Matfield River); C, MA62-32 (lower Matfield River); D, MA62-05 (upper Salisbury Plain River); E, MA62-07 (Trout Brook); F, MA6208 (Salisbury Brook); G, MA62-09 (Beaver Brook); H, MA62-38 (Meadow Brook); I, MA62-33 (Shumatuscacant River); and J, MA32-39 (Rumford River) in the Taunton River Basin. Lower line in each graph is the threshold-yield curve based on 10x dilution of the Brockton Advanced Water Reclamation Facility (AWRF) maximum allowable daily total suspended solids concentration in treated effluent. Upper line is the threshold-yield curve based on an informal Massachusetts Department of Environmental Protection (MA DEP) guideline for total suspended solids concentration in streams. 


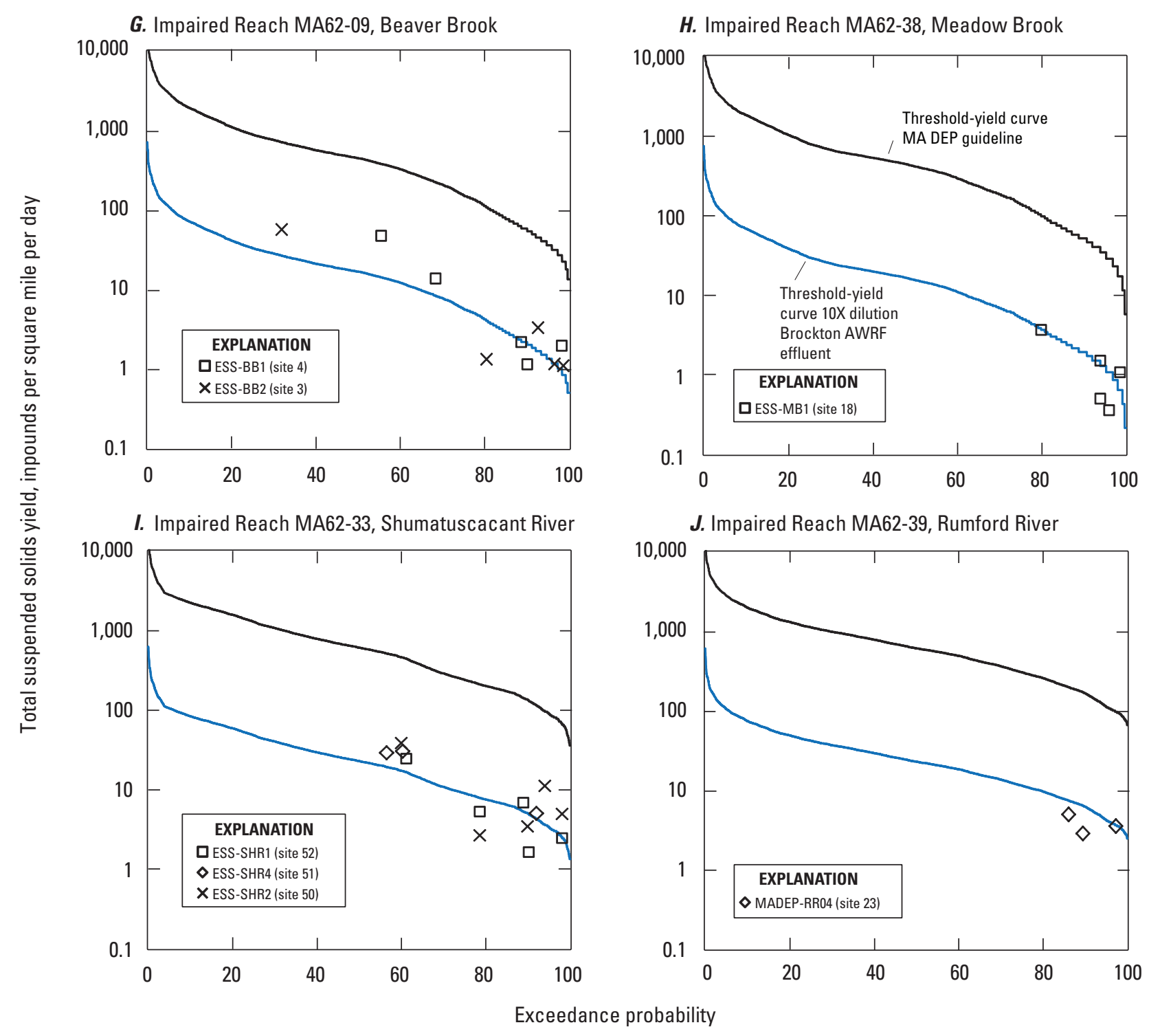

Figure 9. Total suspended solids yield-duration plots for impaired reaches $A$, MA62-06 (lower Salisbury Plain River); $B$, MA62-32 (upper Matfield River); $C$, MA62-32 (lower Matfield River); D, MA62-05 (upper Salisbury Plain River); E, MA62-07 (Trout Brook); F, MA62-08 (Salisbury Brook); G, MA62-09 (Beaver Brook); H, MA62-38 (Meadow Brook); I, MA62-33 (Shumatuscacant River); and J, MA32-39 (Rumford River) in the Taunton River Basin. Lower line in each graph is the threshold-yield curve based on 10x dilution of the Brockton Advanced Water Reclamation Facility (AWRF) maximum allowable daily total suspended solids concentration in treated effluent. Upper line is the threshold-yield curve based on an informal Massachusetts Department of Environmental Protection (MA DEP) guideline for total suspended solids concentration in streams. - Continued 
A. Taunton River at Titicut Street, Bridgewater

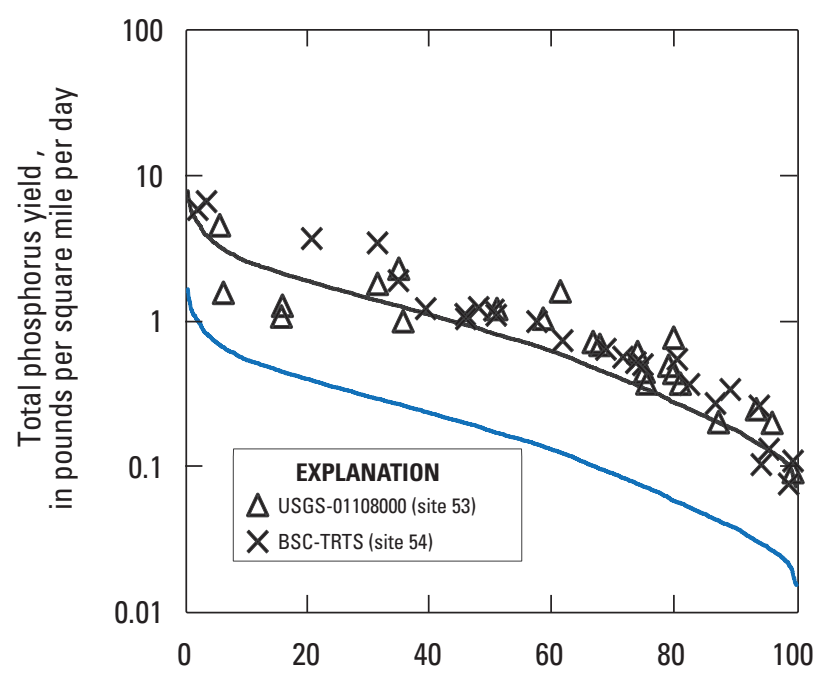

Taunton River near the Berkley Bridge,

100 Dighton/Berkley line

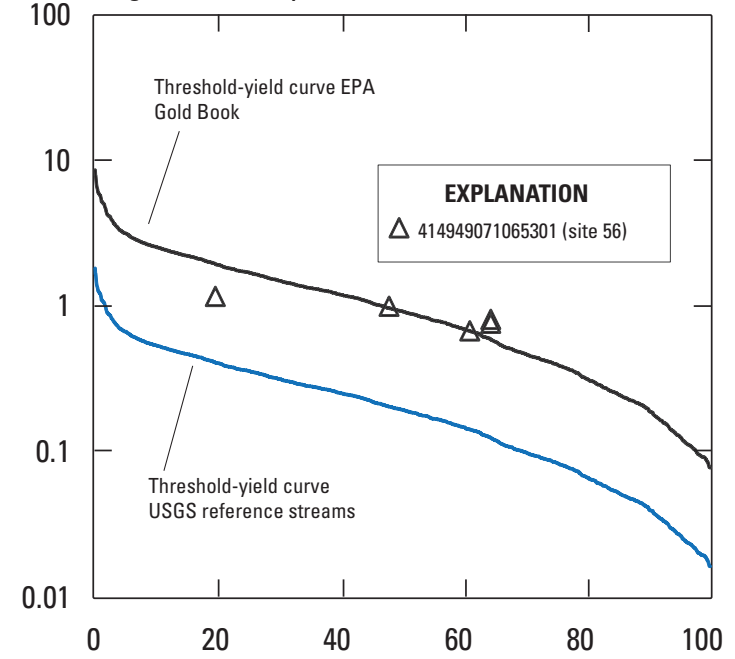

Exceedance probability

B. Taunton River at Titicut Street, Bridgewater

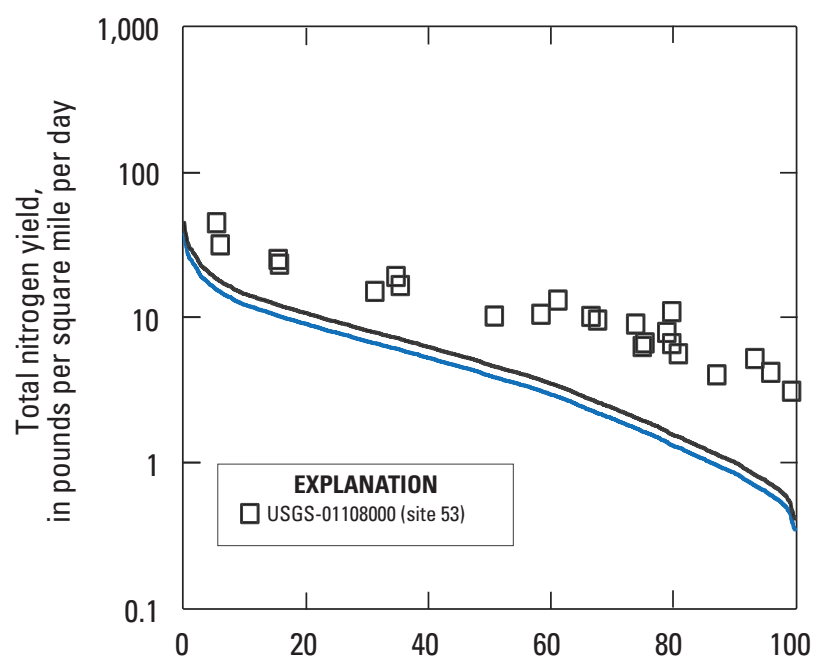

Taunton River near the Berkley Bridge, Dighton/Berkley line

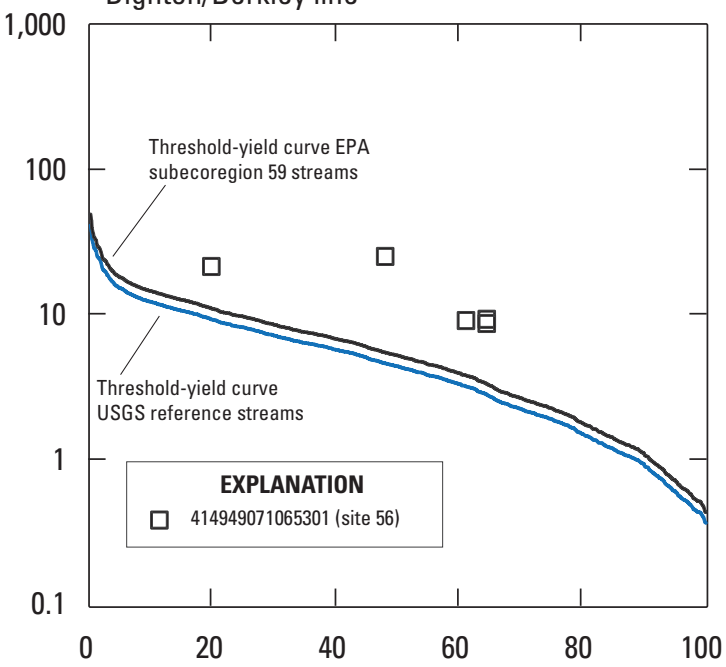

Exceedance probability

Figure 10. Yield-duration plots for water-quality sampling sites on the Taunton River at the U.S. Geological Survey (USGS) streamgage at Titicut Street (station no. 01108000), Bridgewater, and near the Berkley Bridge, Dighton/Berkley line for $A$, total phosphorus, and $B$, total nitrogen, Taunton River Basin. Lower line for graphs in $A$ is the threshold-yield curve based on the 75th percentile total phosphorus concentration for USGS reference streams. Upper line for graphs in $A$ is the threshold-yield curve based on the U.S. Environmental Protection Agency (EPA) "Gold Book" total phosphorus concentration. Lower line for graphs in B is the threshold-yield curve based on the 75th percentile total nitrogen concentration for USGS reference streams. Upper line for graphs in B is the threshold-yield curve based on the 25th percentile total nitrogen concentration for EPA subecoregion 59 streams. 


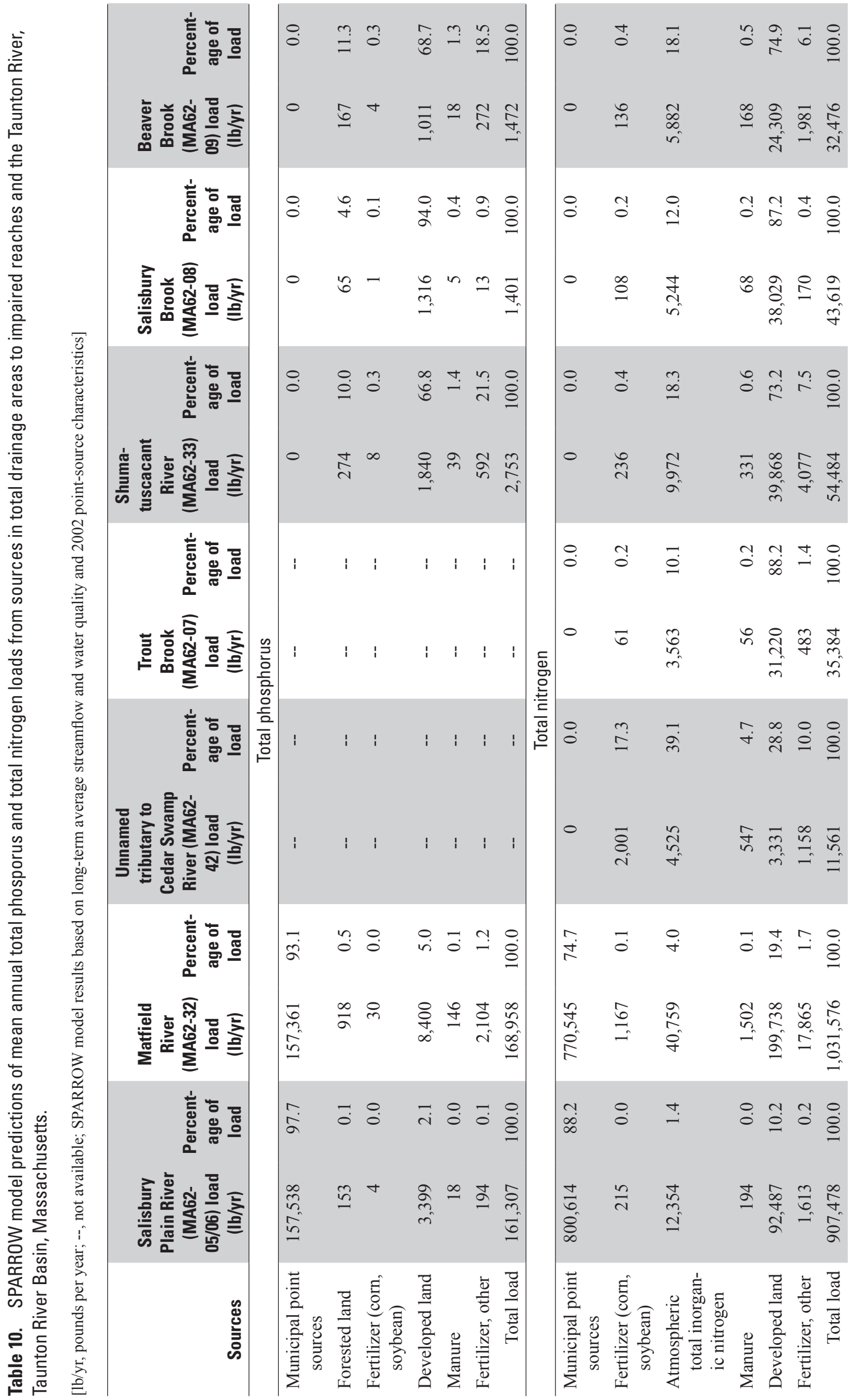




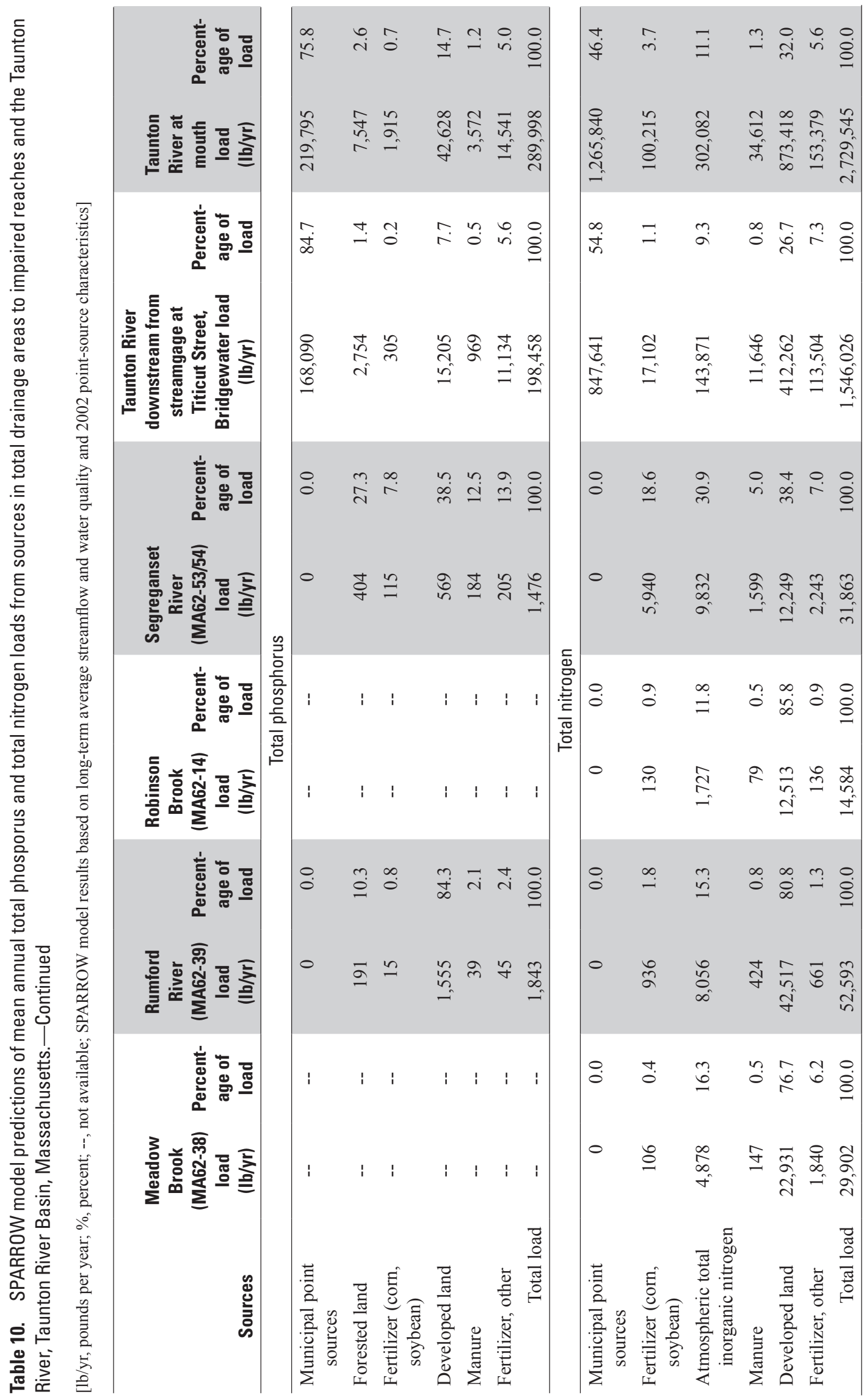




\section{Summary and Conclusions}

The 533 square miles $\left(\mathrm{mi}^{2}\right)$ Taunton River Basin in southeastern Massachusetts is undergoing rapid economic development and population growth and the changes in land and water use accompanying development are placing increasing stress on water resources in the basin. An assessment by the Massachusetts Department of Environmental Protection (MA DEP) determined that a number of tributary streams and ponds in the basin are impaired for a variety of beneficial uses. Most of the impaired reaches are in the Matfield River drainage area, in the vicinity of the City of Brockton. Nutrients (total phosphorus and total nitrogen) and sediment are the constituents of concern in the impaired reaches. In addition to impairments within the basin, discharge of nutrient-rich water from the Taunton River to Mount Hope Bay contributes to eutrophication of Mount Hope and Narragansett Bays. To assess water quality and loading in the impaired reaches of the basin, the U.S. Geological Survey (USGS), in cooperation with MA DEP, compiled existing water-quality data from previous studies in the impaired-reach areas for the period 1997-2006, developed and calibrated a Hydrological Simulation ProgramFORTRAN (HSPF) precipitation-runoff model for streamflow for areas of the basin that contain impaired reaches, and collected additional streamflow and water-quality data from sites on the Matfield and Taunton Rivers in 2008. The model and water-quality data were used to estimate constituent loads in the impaired reaches and Taunton River using existing and new water-quality data and to develop yield-duration plots for reaches with sufficient water-quality data. A majority of the water-quality samples used in the study were collected between 1999 and 2006. Overall, the concentration, yield, and load data presented in this report represent water-quality conditions in the basin for the period 1997-2008.

The HSPF model was constructed for the entire basin but calibrated only for drainage areas to the impaired reaches. Three streamgages (Matfield River at Elmwood, East Bridgewater; Poor Meadow Brook at South Hanson; and Segreganset River near Dighton) were used to calibrate the model for streamflow. The model was calibrated for a 10 -year period (1997-2006). The drainage areas to the unnamed tributary to Cedar Swamp River (impaired reach MA62-42), Robinson Brook (MA62-14), and Rumford River (MA62-39) did not contain streamgages that could be used for model calibration, but water-use stresses in these areas were represented and the calibrated model was considered to represent the hydrology of the basin well enough to use the simulated streamflow from these areas in the analysis. Simulated streamflow was used to estimate constituent loads and develop yield-duration plots for the impaired reaches in the basin.

Data from previous studies in the basin were used to evaluate water quality and constituent loading in the impaired reaches and the main stem of the Taunton River. Data from 63 sampling sites at 50 unique locations collected over a 10-year period (1997-2006) were used in the analysis. Most sites were sampled between one and five times over the course of a 6-month sampling program, and most of the samples were collected June through September under dry-weather conditions (defined as less than 0.1 inch of precipitation in the 48-hour period preceding the sampling event).

In the impaired-reach areas, total phosphorus data were available from 58 of 60 sites, and concentrations in individual samples ranged from 0.0046 to 0.91 milligrams per liter $(\mathrm{mg} / \mathrm{L})($ number of samples $(\mathrm{n})=331)$, with a median of $0.090 \mathrm{mg} / \mathrm{L}$. Total nitrogen (nitrate + nitrite + ammonia + organic nitrogen) data were available from 14 of 60 sites, and concentrations in individual samples ranged from 0.34 to $14 \mathrm{mg} / \mathrm{L}$ ( $\mathrm{n}=139$ ), with a median of $1.35 \mathrm{mg} / \mathrm{L}$. Concentrations of total phosphorus and total nitrogen in most of the samples collected from the impaired-reach areas were higher than various nutrient guidelines for reference streams in the northeast. Nutrient criteria represent threshold concentrations expected to limit eutrophication in freshwater streams. Total suspended solids (TSS) data were available from 39 of 60 sites; concentrations were relatively low, ranging from less than 1 to $69 \mathrm{mg} / \mathrm{L}$ ( $\mathrm{n}=155$ ), with a median of $5.3 \mathrm{mg} / \mathrm{L}$.

Among the impaired reaches, median total phosphorus concentrations ranged from $0.016 \mathrm{mg} / \mathrm{L}$ in the Rumford River (impaired reach MA62-39) to $0.22 \mathrm{mg} / \mathrm{L}$ in the upper Matfield River (MA62-32); median total nitrogen concentrations ranged from $0.61 \mathrm{mg} / \mathrm{L}$ in the Rumford River (MA62-39) to $6.2 \mathrm{mg} / \mathrm{L}$ in the Salisbury Plain River (MA62-06), and median TSS concentrations ranged from $2 \mathrm{mg} / \mathrm{L}$ in the Rumford River (MA62-39) to $8 \mathrm{mg} / \mathrm{L}$ in Trout Brook (MA62-07). Median concentrations of nutrients were highest in the lower Salisbury Plain and Matfield Rivers, the reaches downstream from the Brockton Advanced Water Reclamation Facility (AWRF) outfall. High concentrations indicate that the outfall was a major point source for nutrients for the period 1999-2006 when these data were collected. In the remaining impaired reaches affected only by diffuse (nonpoint) sources, median concentrations were substantially lower than in reaches downstream from the outfall and generally increased with the percentage of developed land in the drainage area to the reach. A Spearman rho rank correlation test was used to evaluate relations between median concentration and the percentage of developed land in the drainage area to the reach. Correlation coefficients for reaches affected by diffuse sources only were $0.667(\mathrm{p}=0.07)$ for total phosphorus $(\mathrm{n}=8)$, and $0.750(\mathrm{p}=0.05)$ for both total nitrogen and TSS $(n=7)$. The finding that nutrient concentrations increase as a function of anthropogenic inputs to the watershed is consistent with many other published studies.

The USGS collected water-quality samples and streamflow measurements in 2008 at sites on the tidally influenced Taunton River about 6 miles upstream from the mouth and the Matfield River at the USGS streamgage at Elmwood, East Bridgewater. These data were collected to determine recent (2008) nutrient concentrations and loads at these sites. Comparison of the 2008 data from the Matfield River site with 2002 data collected from the same location indicates that total phosphorus concentrations decreased by about 60 percent for 
this period (medians of $0.20 \mathrm{mg} / \mathrm{L}$ in 2002 and $0.08 \mathrm{mg} / \mathrm{L}$ in 2008). Lower total phosphorus concentrations in 2008 may reflect recent (2004-2008) upgrades to treatment processes at the Brockton AWRF. A lower total phosphorus concentration at this site in 2008 is consistent with reductions in concentrations in treated effluent that occurred in response to plant upgrades. Data collection at the Berkley Bridge site was timed to coincide with slack water at low tide to measure freshwater nutrient loads from the main stem of the Taunton River to Mount Hope Bay. Results indicate that the sampling approach provided measurements representative of freshwater nutrient and sediment concentrations at this location.

Water-quality and streamflow data were used to estimate loads and yields and construct yield-duration plots for the impaired reaches and the main stem of the Taunton River. Yields (load divided by drainage area) were calculated because they permit a comparison of constituent loads among sampling sites independent of the size of the drainage area. Plots included measured yields and thresholdyield curves. Threshold-yield curves are developed using water-quality guidelines, which are defined as allowable or threshold concentrations expected to limit eutrophication in streams for a wide range in flows. To date (2012), the State of Massachusetts has not established nutrient and sediment guidelines for rivers and streams in the State. Consequently, a range of concentrations from published studies on nutrient enrichment and other sources was used to determine low and high "end member" threshold yields for each constituent. Results showed that total phosphorus yields in the impaired reaches typically were greater than threshold yields based on the 75th percentile total phosphorus concentration $(0.021 \mathrm{mg} / \mathrm{L})$ in two minimally affected USGS reference streams in New England, but less than threshold yields based on the U.S. Environmental Protection Agency (EPA) "Gold Book" concentration $(0.10 \mathrm{mg} / \mathrm{L})$. Total nitrogen yields in the impaired reaches typically were greater than threshold yields based on both the 75th percentile total nitrogen concentration $(0.48 \mathrm{mg} / \mathrm{L})$ in the minimally affected reference streams, and the 25 th percentile concentration $(0.57 \mathrm{mg} / \mathrm{L})$ for EPA subecoregion 59 streams. TSS yields in the impaired reaches typically were greater than threshold yields based on a tenfold dilution of the Brockton AWRF winter daily maximum effluent limit of $30 \mathrm{mg} / \mathrm{L}(3 \mathrm{mg} / \mathrm{L})$, but less than an informal MA DEP guideline $(80 \mathrm{mg} / \mathrm{L})$. Similar to concentrations, the highest total phosphorus and total nitrogen yields were observed in the reaches downstream from the Brockton AWRF outfall (lower Salisbury Plain River, MA62-06; and upper and lower Matfield River, MA62-32). Yields for lower flows were up to 7 pounds per square mile per day $\left(\mathrm{lb} / \mathrm{mi}^{2} / \mathrm{d}\right)$ for total phosphorus and $100 \mathrm{lb} / \mathrm{mi}^{2} / \mathrm{d}$ for total nitrogen in these reaches. In most of the impaired reaches not affected by the Brockton AWRF outfall, yields were lower than in reaches downstream from the outfall, and the difference between measured and threshold yields was fairly uniform over a wide range of flows, suggesting that multiple processes contribute to nonpoint loading in these reaches.
The Northeast and Mid-Atlantic SPAtially-Referenced Regression On Watershed attributes (SPARROW) models for total phosphorus and total nitrogen also were used to calculate mean annual nutrient loads for the impaired reaches and main stem of the Taunton River and determine the distribution of these loads among point and diffuse sources in the drainage areas to these reaches. SPARROW is a regional, statistical model that relates nutrient loads in streams to upstream sources and land-use characteristics and can be used to make predictions for streams that do not have nutrient-load data. The model predicts mean annual loads based on long-term streamflow and water-quality data and nutrient source conditions for the year 2002. Predicted mean annual nutrient loads from the SPARROW models were consistent with the measured yield and load data from sampling sites in the basin. Results indicate that the municipal point source (that is, the Brockton AWRF outfall) was the major source for constituent loads in the impaired-reach areas for the year 2002. In the impaired reaches immediately downstream from the outfall, the point source accounted for about 75 percent of the total nitrogen load and over 93 percent of the total phosphorus load. Municipal point sources continued to account for most of the load in the main stem of the Taunton River. Multiple municipal wastewater discharges in the basin accounted for 76 and 46 percent of the delivered (accounting for attenuation) loads of total phosphorus and total nitrogen, respectively, to the mouth of the Taunton River. In the absence of point sources, total delivered loads were lower and sources associated with developed land accounted for most of the total phosphorus and total nitrogen loads to the impaired reaches. For both constituents, sources associated with agricultural and forested land were relatively unimportant in developed watersheds but contributed appreciably to the total load in less developed watersheds. Atmospheric deposition was an important source for total nitrogen, accounting for up to 31 percent of the load to the impaired reaches, and 11 percent of the load to Mount Hope Bay. Developed land also was an important source of total nitrogen and phosphorus in the Taunton River, accounting for 32 and 15 percent, respectively, of the loads delivered to Mount Hope Bay.

The concentration, yield, and load data evaluated in this study may not be representative of current (2012) point-source loading in the basin; in particular, most of the water-quality data used in the study (1999-2006) were collected prior to completion of upgrades to the Brockton Advanced Water Reclamation Facility that reduced total phosphorus and nitrogen concentrations in treated effluent. Effluent concentration data indicate that, for a given flow rate, effluent loads of total phosphorus and total nitrogen declined by about 80 and 30 percent, respectively, between the late 1990s and 2008 in response to plant upgrades. Consequently, current (2012) water-quality conditions in the impaired reaches downstream from the facility likely have improved compared to conditions described in the report. 


\section{References Cited}

Allan, J.D., and Castillo, M.M., 2007, Stream ecology: Structure and function of running waters $(2 \mathrm{~d}$ ed.):

Dordrecht, The Netherlands, Springer, $436 \mathrm{p}$.

Arar, E.J., and Collins, G.B., 1997, U.S. Environmental Protection Agency Method 445.0, In vitro determination of chlorophyll $a$ and pheophytin $a$ in marine and freshwater algae by fluorescence, revision 1.2: Cincinnati, Ohio, U.S. Environmental Protection Agency National Exposure Research Laboratory, Office of Research and Development.

Barbaro, J.R., and Zarriello, P.J., 2006, A precipitation-runoff model for the Blackstone River Basin, Massachusetts and Rhode Island: U.S. Geological Survey Scientific Investigations Report 2006-5213, 85 p.

Bicknell, B.R., Imhoff, J.C., Kittle, J.L., Jr., Jobes, T.H., and Donigian, A.S., Jr., 2000, Hydrological Simulation Program-FORTRAN User's manual for release 12: Mountain View, Calif., AQUA TERRA Consultants, variously paged.

Boyer, E.W., Goodale, C.L., Jaworski, N.A., and Howarth, R.W., 2002, Anthropogenic nitrogen sources and relationships to riverine nitrogen export in the northeastern USA: Biogeochemistry, v. 57, p. 137-169.

Cleland, B.R., 2002, TMDL development from the "Bottom Up": Part II-Using duration curves to connect the pieces, in Proceedings of WEF Specialty Conference, National TMDL Science and Policy 2002, Water Environment Federation, Alexandria, Va., $11 \mathrm{p}$.

Cleland, B.R., 2003, TMDL development from the "Bottom Up"-Part III: Duration curves and wet-weather assessments, in 2003 National TMDL Science and Policy Conference, Water Environment Federation, November 16-19, 2003, Chicago, Ill., 27 p.

Correll, D.L., 1998, The role of phosphorus in the eutrophication of receiving waters: A review: Journal of Environmental Quality, v. 27, p. 261-266.

Dodds, W.K., Smith, V.H., and Zander, B., 1997, Developing nutrient targets to control benthic chlorophyll levels in streams: A case study of the Clark Fork River: Water Research, v. 31, no. 7, p. 1738-1750.

Dodds, W.K., and Welch, E.B., 2000, Establishing nutrient criteria in streams: Journal of the North American Benthological Society, v. 19, no. 1, p. 186-196.

ENSR Corporation, 2000, Quality assurance project plan for pilot project for the determination of site specific metals criteria in the Taunton Basin, $54 \mathrm{p}$.
ENSR Corporation, 2002, Application of biotic ligand model (BLM): Copper at selected locations in the Taunton River Basin, Massachusetts: No. 2000-09/104, 943 p.

ESS Group Incorporated, 2002, Quality assurance project plan for Matfield River sub-watershed stormwater assessment and plan, $93 \mathrm{p}$.

ESS Group Incorporated, 2003, Matfield and Salisbury Plain River Watersheds nonpoint source pollution assessment report and management plan: Prepared for Massachusetts Department of Environmental Protection, Division of Watershed Management, $119 \mathrm{p}$.

Fishman, M.J., ed., 1993, Methods of analysis by the U.S. Geological Survey National Water-Quality LaboratoryDetermination of inorganic and organic constituents in water and fluvial sediments: U.S. Geological Survey OpenFile Report 93-125, 217 p.

Fishman, M.J., and Friedman, L.C., 1989, Methods for determination of inorganic substances in water and fluvial sediments: U.S. Geological Survey Techniques of WaterResources Investigations, book 5, chap. A1, 545 p.

Frimpter, M.H., 1973, Ground-water management, Taunton River Basin, Massachusetts: U.S. Geological Survey OpenFile Report 73-84, 35 p.

Goodrich, D.M., 1988, On meteorologically induced flushing in three U.S. East Coast estuaries: Estuarine, Coastal and Shelf Science, v. 26, p. 111-121.

Gray, J.R., Glysson, G.D., Turcios, L.M., and Schwarz, G.E., 2000, Comparability of suspended-sediment concentration and total suspended solids data: U.S. Geological Survey Water-Resources Investigations Report 00-4191, 20 p.

Hem, J.D., 1985, Study and interpretation of the chemical characteristics of natural water, $3 d$ ed.: U.S. Geological Survey Water-Supply Paper 2254, 263 p.

Howarth, R.W., Billen, G., Swaney, D., Townsend, A., Jaworski, N., Lajtha, K., Downing, J.A., Elmgren, R., Caraco, N., Jordan, T., Berendse, F., Freney, J., Kudeyarov, V., Murdoch, P., and Zhao-Liang, Z., 1996, Regional nitrogen budgets and riverine $\mathrm{N} \& \mathrm{P}$ fluxes for the drainages to the North Atlantic Ocean: Natural and human influences: Biogeochemistry, v. 35, p. 75-139.

Howes, B., and Samimy, R., 2006, Sampling and analysis plan Mount Hope Bay estuarine monitoring: Mount Hope Bay and Taunton River Estuary (final) year 32006 sampling: School for Marine Science and Technology (SMAST) at the University of Massachusetts at Dartmouth, $30 \mathrm{p}$.

Isaac, R.A., 1997, Estimate of nutrient loadings and their impacts on dissolved oxygen demonstrated in Mount Hope Bay: Environment International, v. 23, no. 2, p. 151-165. 
Kincaid, C., Pockalny, R.A., and Huzzey, L.M., 2003, Spatial and temporal variability in flow at the mouth of Narragansett Bay: Journal of Geophysical Research, v. 108(C7), p. 3218, doi:10.1029/2002JC001395.

Lane, S.L., Flanagan, S.M., and Wilde, F.D., 2003, Selection of equipment for water sampling (ver. 2.0): U.S. Geological Survey Techniques of Water-Resources Investigations, book 9, chap. A2, March 2003, accessed August 15, 2008, at http://pubs.water.usgs.gov/twri9A2/.

Lapham, W.W., 1988, Yield and quality of ground water from stratified-drift aquifers, Taunton River Basin, Massachusetts: U.S. Geological Survey Water-Resources Investigations Report 86-4053, 69 p.

Leopold, L.B., 1994, A view of the river: Cambridge, Mass., Harvard University Press, 298 p.

Massachusetts Department of Environmental Protection, 1998, Quality assurance project plan for 1996 water and biological studies in the Taunton River Basin, Division of Watershed Management: Environmental Monitoring and Assessment Program, CN 023.0, $24 \mathrm{p}$.

Massachusetts Department of Environmental Protection, 2005, Taunton River Watershed 2001 Water Quality Assessment Report, Massachusetts Department of Environmental Protection, Division of Water Management: Worcester, Mass., report no. 62-AC-1, CN 94.0, 46 p.

Massachusetts Department of Environmental Protection, 2006a, Massachusetts year 2006 integrated list of waters, proposed listing of the condition of Massachusetts' waters pursuant to Sections 303(d) and 305(b) of the Clean Water Act, Featuring new water quality assessments for the Concord (SuAsCo), Farmington, Taunton and Westfield watersheds and the South Coastal drainage area: CN 262.0, $196 \mathrm{p}$.

Massachusetts Department of Environmental Protection, 2006b, Sampling plan for year 2006 surface water monitoring in the Taunton River Watershed, Division of Watershed Management: Environmental Monitoring and Assessment Program, CN 234.0, 20 p.

Massachusetts Department of Environmental Protection and the School of Marine Science and Technology (SMAST), 2006, Quality assurance project plan revisions for the Massachusetts estuaries project round 5 embayment prioritization, $131 \mathrm{p}$.

Massachusetts Office of Geographic Information (MassGIS), 2008a, Land use data layer and metadata: Massachusetts Office of Geographic Information, accessed 2008, at http://www.mass.gov/mgis/lus.htm.
Massachusetts Office of Geographic Information (MassGIS), 2008b, Surficial geology data layer and metadata:

Massachusetts Office of Geographic Inforamtion, accessed 2008, at http://www.mass.gov/mgis/sg24k.htm.

Massachusetts Office of Geographic Information (MassGIS), 2008c, Wetland data layer and metadata: Massachusetts Office of Geographic Information, accessed 2008, at http://www.mass.gov/mgis/wetdep.htm.

Massachusetts State Data Center, 2011, Population statistics: Massachusetts State Data Center, accessed 2011, at http://www.massbenchmarks.org/statedata/data.htm.

Moore, R.B., Johnston, C.M., Smith, R.A., and Milstead, B., 2011, Source and delivery of nutrients to receiving waters in the Northeastern and mid-Atlantic regions of the United States: Journal of the American Water Resources Association, DOI: 10.1111/j.1752-1688.2011.00582x, p. 1-26.

Nixon, S.W., Granger, S.L., and Nowicki, B.L., 1995, An assessment of the annual mass balance of carbon, nitrogen, and phosphorus in Narragansett Bay: Biogeochemistry, v. 31 , p. $15-61$.

Norris, J.M., Hren, J., Myers, D.N., Chaney, T.H., and Childress, C.J.O., 1992, Water-quality data-collection activities in Colorado and Ohio: Phase III-evaluation of existing data for use in assessing regional water-quality conditions and trends: U.S. Geological Survey WaterSupply Paper 2295-C, 54 p.

Omernik, J.M., 1977, Nonpoint source-stream nutrient level relationships: A nationwide study: U.S. Environmental Protection Agency, Office of Research and Development, Special Studies Branch, Corvallis Environmental Research Laboratory: Corvallis, Oreg., EPA-600/3-77-105.

Pilson, M., 1985a, On the residence time of water in Narragansett Bay: Estuaries, v. 8, p. 2-14.

Pilson, M., 1985b, Annual nutrient cycles and chlorophyll in Narragansett Bay, Rhode Island: Journal of Marine Research, v. 43, p. 849-873.

Rhode Island Department of Environmental Management, 2003, The Greenwich Bay fish kill, August 2003, causes, impacts and responses: Rhode Island Department of Environmental Management, $32 \mathrm{p}$.

Riskin, M.L., Deacon, J.R., Liebman, M.L., and Robinson, K.W., 2003, Nutrient and chlorophyll relations in selected streams of the New England Coastal Basins in Massachusetts and New Hampshire, June-September, 2001: U.S. Geological Survey Water-Resources Investigations Report 03-4191, 16 p. 
U.S. Census Bureau, 2011, 2000 Census Blocks: digital data accessed 2011 at http://www.mass.gov/mgis/cen2000 blocks.htm.

U.S. Environmental Protection Agency, 1986, Quality criteria for water 1986: Office of Water, EPA 440/5-86-001, variously paged.

U.S. Environmental Protection Agency, 2000, Ambient water quality criteria recommendations-Information supporting the development of state and tribal nutrient criteria-Rivers and streams in Nutrient Ecoregion XIV: Office of Water, EPA 822-B-00-022, variously paged.

U.S. Environmental Protection Agency, 2003, Developing water quality criteria for suspended and bedded sediments (SABs)_Potential approaches (Draft): Office of Water, USEPA Science Advisory Board Consultation, 58 p.

U.S. Geological Survey, 2008, Quality assurance project plan for streamflow and water-quality assessment of impaired reaches in the Taunton River Basin, Massachusetts: U.S. Geological Survey, unpublished, $67 \mathrm{p}$.

U.S. Geological Survey, variously dated, National field manual for the collection of water-quality data: U.S. Geological Survey Techniques of Water-Resources Investigations, book 9, chaps. A1-A9, accessed various dates, at http://pubs.water.usgs.gov/twri9A.

Wandle, S.W., and Keezer, G.R., 1984, Gazetteer of hydrologic characteristics of streams in Massachusetts; Taunton and Ten Mile River Basins and coastal river basins of Mount Hope Bay, Narragansett Bay, and Rhode Island Sound: U.S. Geological Survey Water-Resources Investigations Report 84-4283, 42 p.
Watershed Access Laboratory, 2008, Laboratory quality assurance plan for the Watershed Access Laboratory: Volunteer water quality monitoring support program: Bridgewater State College, Revision 5.0, 35 p.

Weiskel, P.K., Brandt, S.L., DeSimone, L.A., Ostiguy, L.J., and Archfield, S.A., 2009, Indicators of streamflow alteration, habitat fragmentation, impervious cover, and water quality for Massachusetts stream basins: U.S. Geological Survey Scientific Investigations Report 20095272,70 p.

Williams, J.R., 1968, Availability of ground water in the northern part, Ten Mile and Taunton River Basins, southeastern Massachusetts: U.S. Geological Survey Hydrological Investigations Atlas HA-300.

Williams, J.R., Farrell, D.F., and Willey, R.E., 1973, Water resources of the Taunton River basin, southeastern Massachusetts: U.S. Geological Survey Hydrologic Investigations Atlas HA-460, scale 1:48,000.

Williams, J.R., and Willey, R.E., 1973, Bedrock topography and texture of unconsolidated deposits, Taunton River Basin, southeastern Massachusetts: U.S. Geological Survey Miscellaneous Investigations Map I-742.

Zimmerman, M.J., and Campo, K.W., 2007, Assessment of data for use in the development of nutrient criteria for Massachusetts rivers and streams: U.S. Geological Survey Scientific Investigations Report 2007-5022, 44 p. 


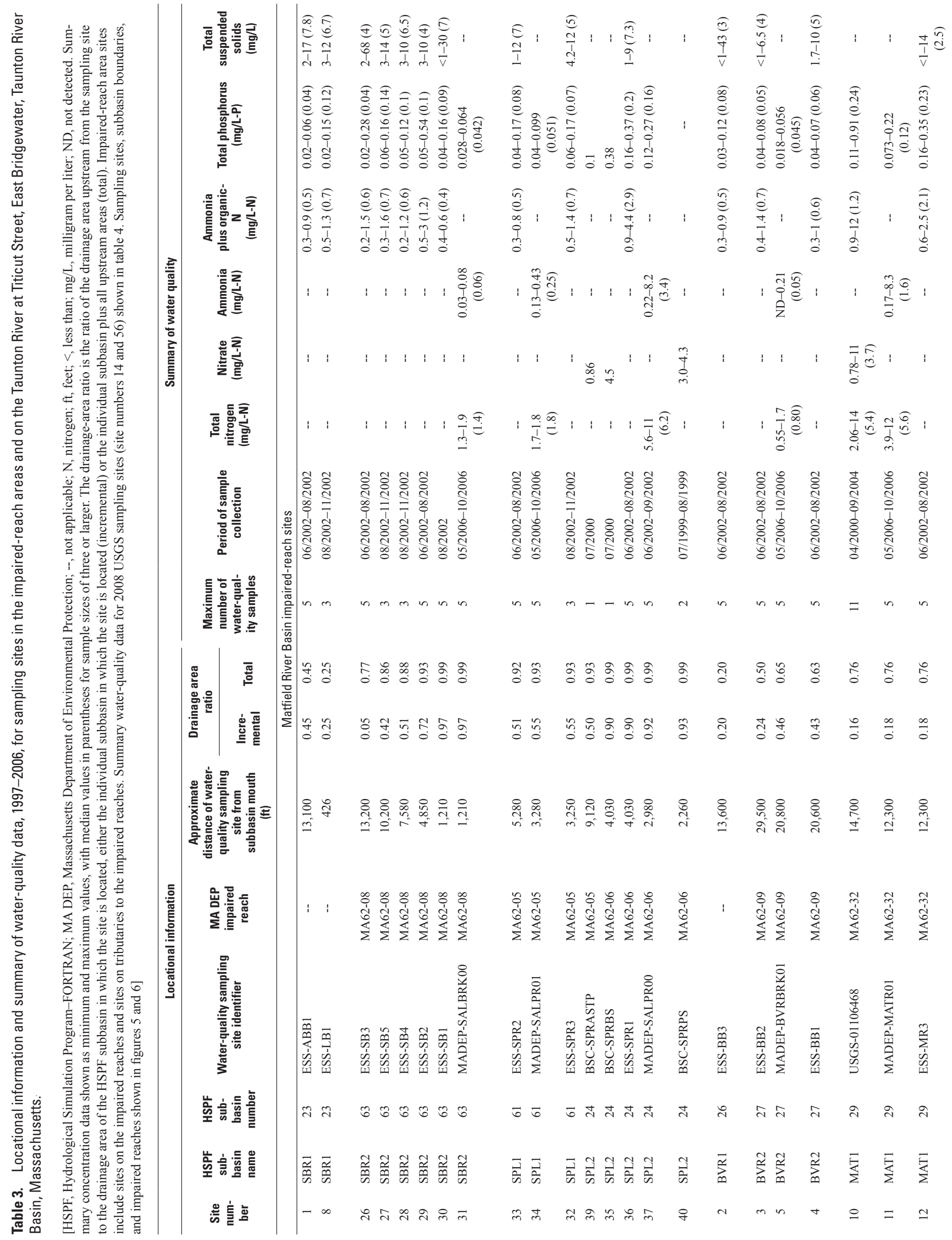



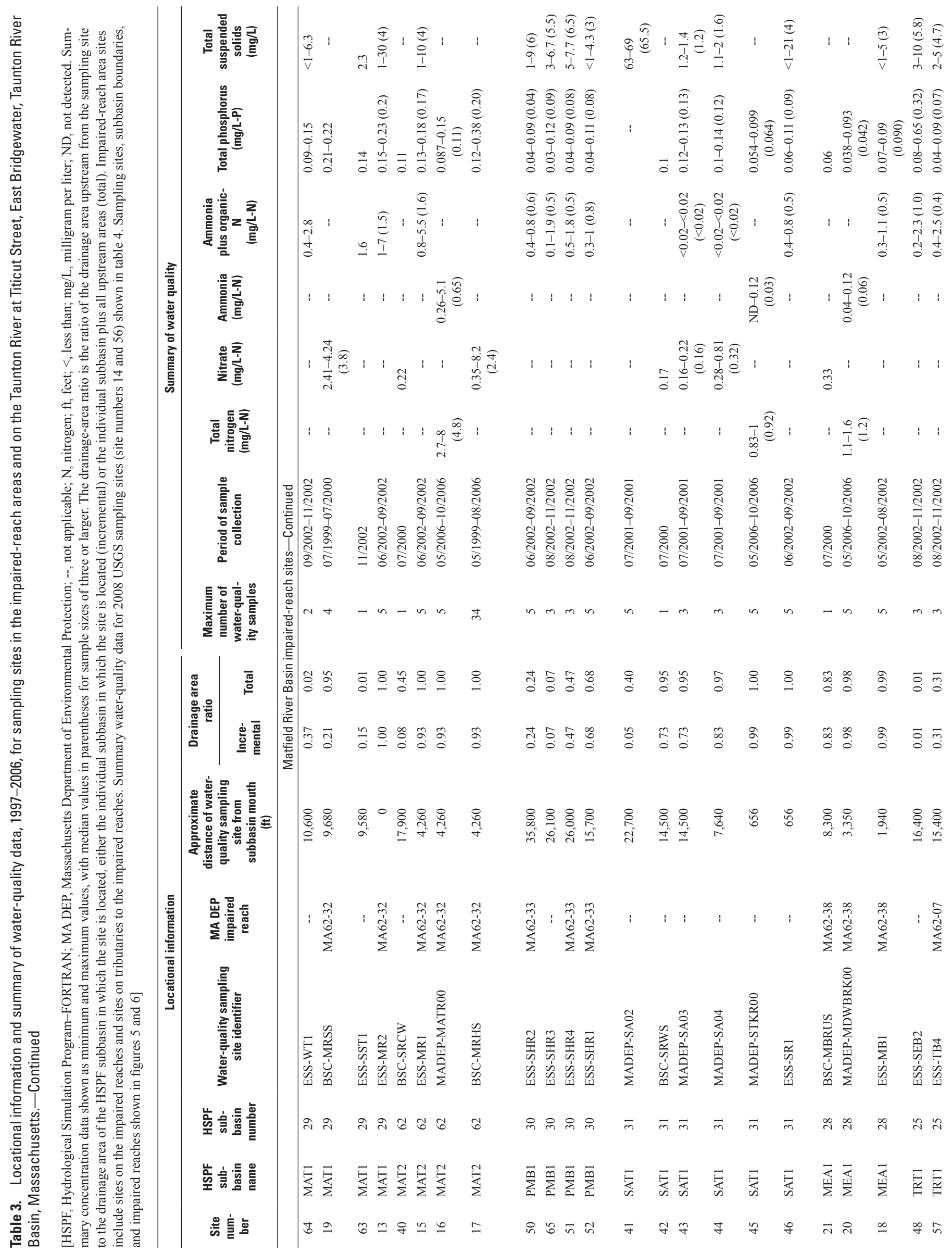


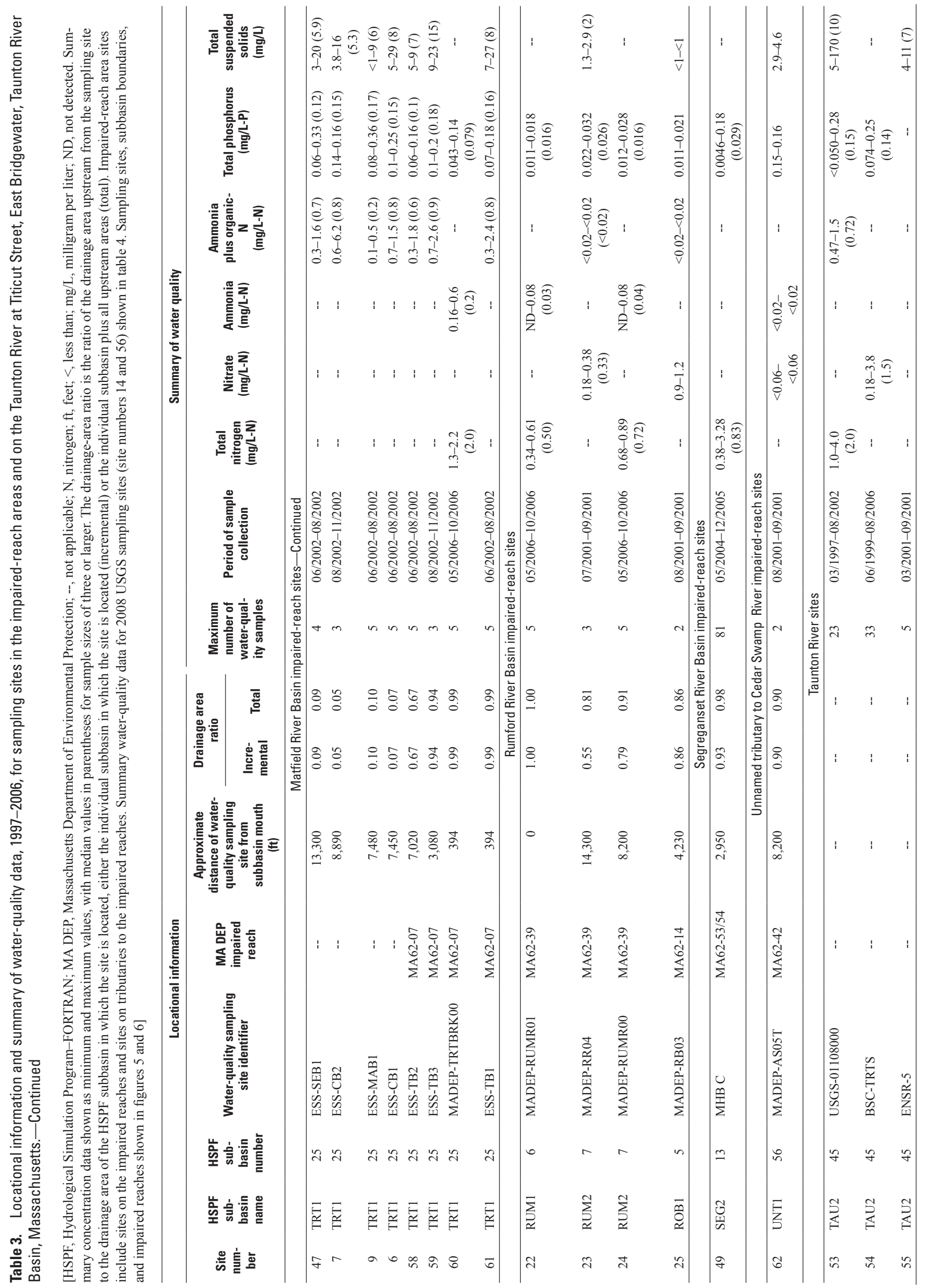




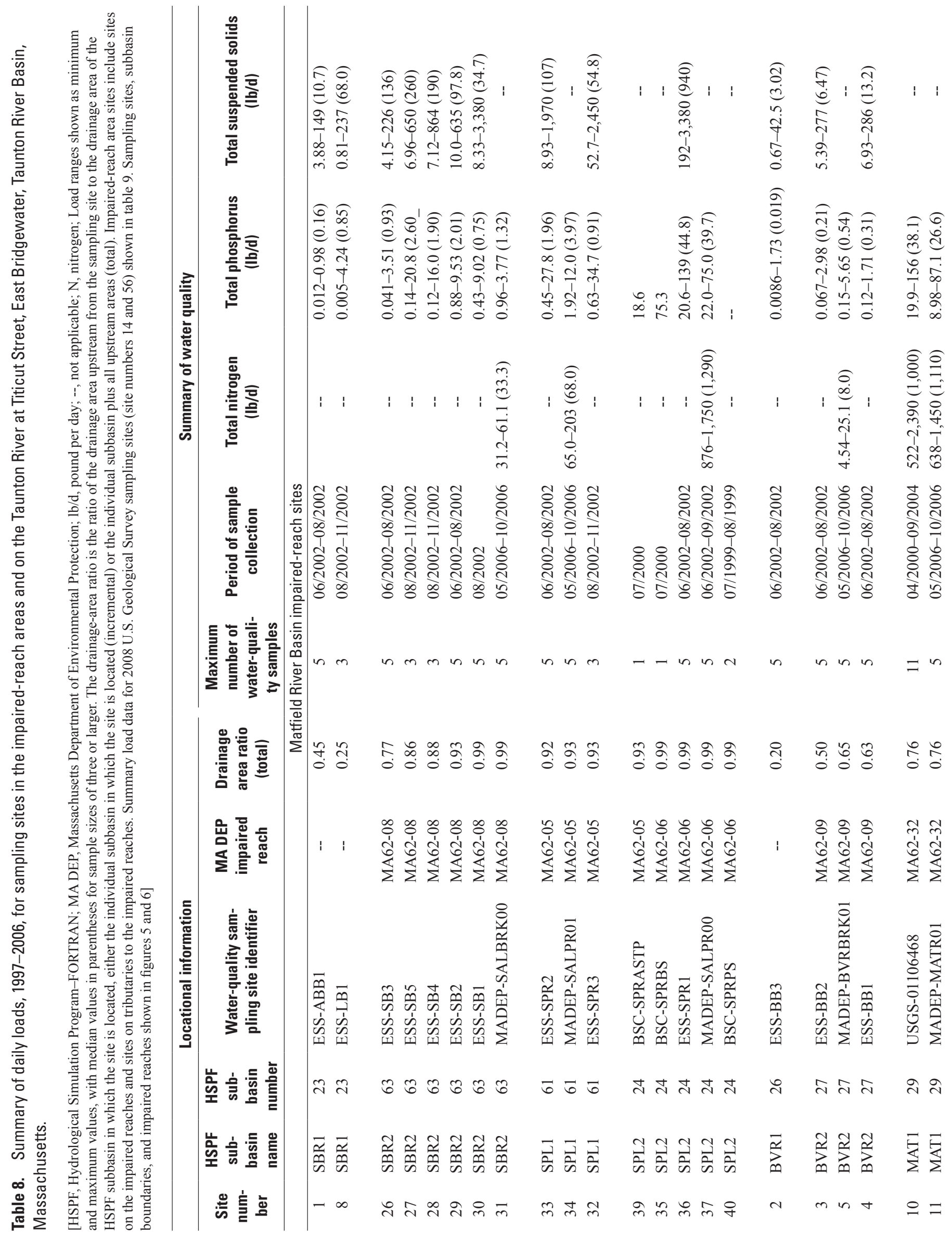




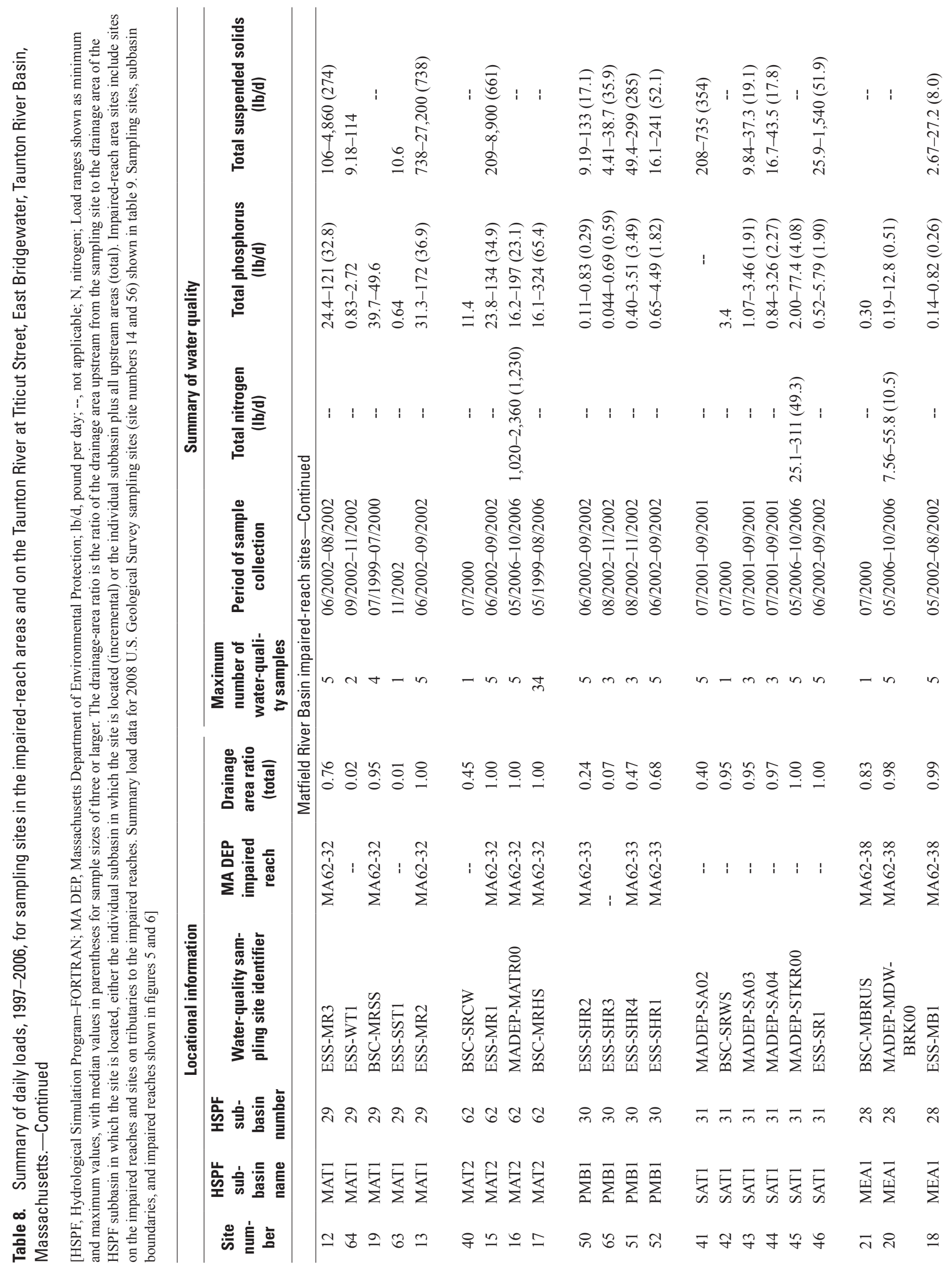


Table 8

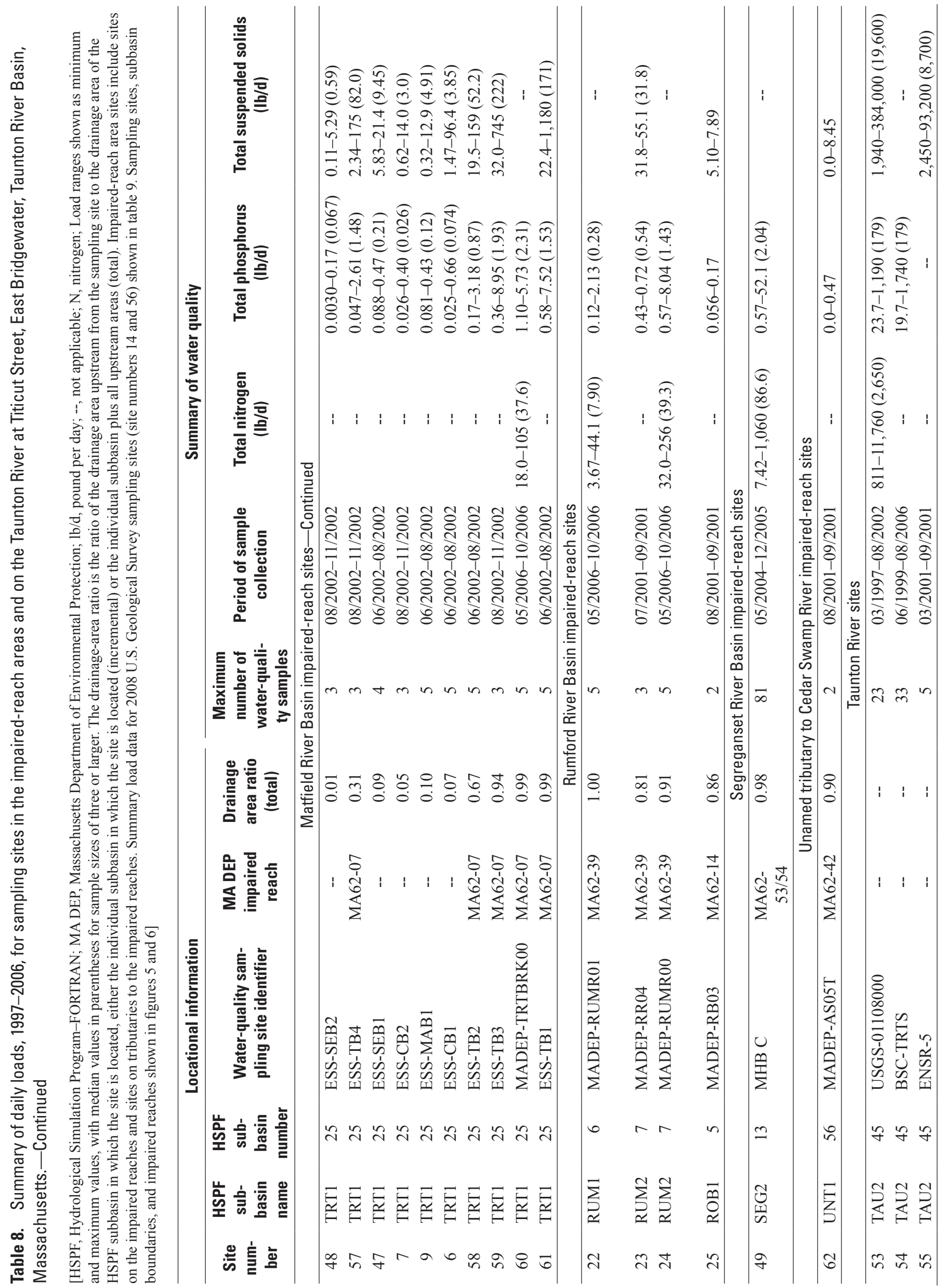


THIS PAGE INTENTIONALLY LEFT BLANK 


\section{Appendix 1. Development and Calibration of the Hydrological Simulation Program- FORTRAN (HSPF) Precipitation-Runoff Model of the Taunton River Basin}

\section{Contents}

Description of Hydrologic Simulation Program-FORTRAN (HSPF) ..............................................58

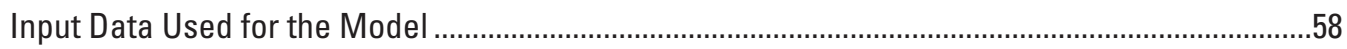

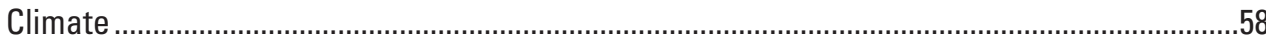

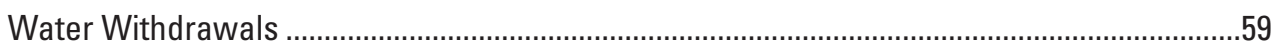

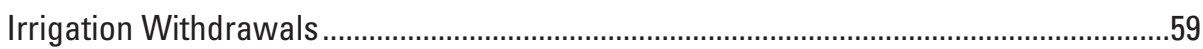

Streamflow Depletion by Groundwater Withdrawals .................................................63

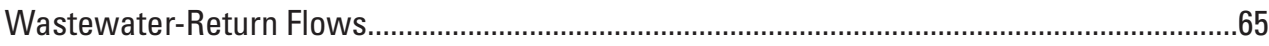

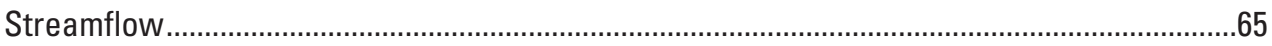

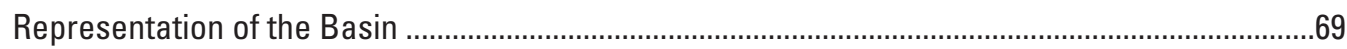

Surficial Geology......................................................................................................

Land Use and Land Cover................................................................................................

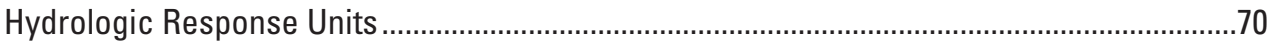

Effective Impervious Areas (IMPLNDs) ..........................................................................

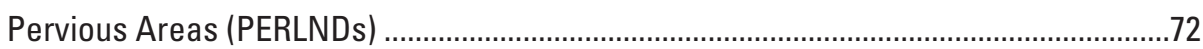

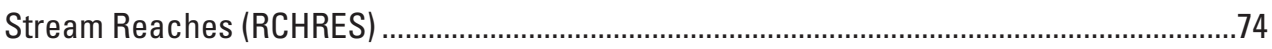

Hydraulic Characteristics (FTABLEs) .......................................................................

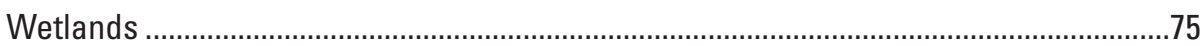

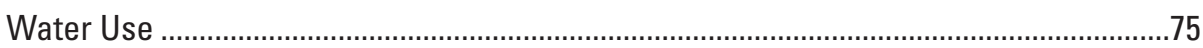

Municipal, Commercial, and Irrigation Withdrawals...................................................78

Municipal and Industrial Wastewater-Return Flows...................................................78

Septic-Effluent Returns in Residential Areas with Public-Water Supplies......................79

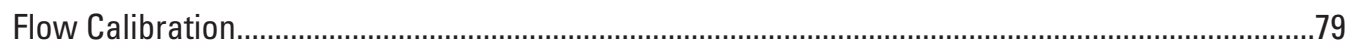

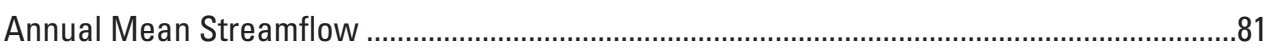

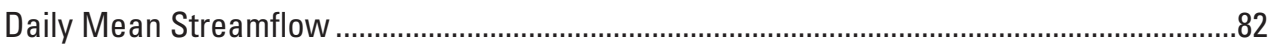

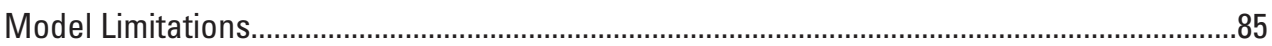

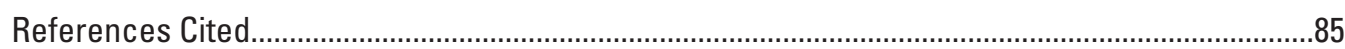




\section{Figures}

1-1. Map showing location of water withdrawals and wastewater-return flows in the impaired-reach areas of the Taunton River Basin, Massachusetts

1-2. Map showing model reaches and subbasin boundaries for the Hydrological Simulation Program-FORTRAN (HSPF) model of the Taunton River Basin, Massachusetts 64

1-3. Map showing streamgages in the Taunton River Basin in 2008, Massachusetts ...........68

1-4. Bar graphs showing relation between observed and simulated annual mean streamflow at calibration sites $A$, Segreganset River near Dighton (01109070); $B$, Matfield River at Elmwood, East Bridgewater (01106500); and C, Poor Meadow Brook at South Hanson (01106900) .

1-5. Graphs showing daily precipitation at T.F. Green Regional Airport, Warwick, Rhode Island (January 1, 1997-November 4, 1997) and Taunton Municipal Airport, Taunton, Massachusetts (November 5, 1997-December 31, 2006) and observed and simulated daily mean streamflow at calibration sites $A$, Segreganset River near Dighton (01109070); B, Matfield River at Elmwood, East Bridgewater (01106500); and C, Poor Meadow Brook at South Hanson (01106900)

1-6. Scatterplots of observed and simulated daily mean streamflow at calibration sites A, Segreganset River near Dighton (01109070); B, Matfield River at Elmwood, East Bridgewater (01106500); and C, Poor Meadow Brook at South Hanson (01106900).

1-7. Flow-duration curves of observed and simulated daily mean streamflow at calibration sites A, Segreganset River near Dighton (01109070); B, Matfield River at Elmwood, East Bridgewater (01106500); and C, Poor Meadow Brook at South Hanson (01106900)

\section{Tables}

1-1. Municipal, commercial, and irrigation withdrawals in the impaired-reach areas of the Hydrological Simulation Program-FORTRAN (HSPF) model of the Taunton River Basin, Massachusetts

1-2. Wastewater-return flows in the impaired-reach areas of the Hydrological Simulation Program-FORTRAN (HSPF) model of the Taunton River Basin, Massachusetts.

1-3. Streamgages in the Taunton River Basin in 2008, Massachusetts

1-4. Definitions and areas of hydrologic response units for the Hydrological Simulation Program-FORTRAN (HSPF) model of the Taunton River Basin, Massachusetts

1-5. Effective impervious area by developed land-use type for the Hydrological Simulation Program-FORTRAN (HSPF) model of the Taunton River Basin, Massachusetts

1-6. Stream reaches in the Hydrological Simulation Program-FORTRAN (HSPF) model of the Taunton River Basin, Massachusetts

1-7. Hydrological Simulation Program-FORTRAN (HSPF) model-fit statistics for observed and simulated daily mean streamflow for the period 1997-2006, Taunton River Basin, Massachusetts 


\section{Acronyms for HSPF Model}

\begin{tabular}{ll} 
AGWO & Active ground-water outflow from pervious areas \\
AGWRC & Active ground-water recession constant \\
CGAP & Channel Geometry Analysis software Program \\
DSN & Data Set Number associated with the Watershed Data Management database \\
EIA & Effective impervious area \\
FTABLE & Function table that defines the relation between depth, storage and discharge \\
of water in a reach \\
GENFTBL & Generate FTABLE software program \\
GENSCN & Generate Scenarios software program \\
HRU & Hydrologic response unit \\
HSPEXP & Expert system for the HSPF model \\
IMPLND & HSPF impervious-area land element \\
IFWO & Interflow outflow from pervious areas \\
INFILT & Infiltration rate \\
INTFW & Interflow inflow parameter \\
IRC & Interflow recession constant \\
KVARY & Parameter that modifies the linearity of the active ground-water recession \\
LZETP & constant \\
LZLI & Lower-zone evapotranspiration parameter \\
LZSN & Lower zone lateral input \\
MOVE.1 & Lower zone nominal storage \\
PERLND & Maintenance of Variance Extension, Type 1 \\
PET & HSPF pervious-area land element \\
RCHRES & Potential Evapotranspiration \\
STRMDEPL & HSPF steam or reservoir reach \\
SURO & Analytical program to compute streamflow depletion from a pumped well \\
UCI & Surface-water runoff from pervious areas \\
UZSN & HSPF user control input file \\
WDM & Upper zone nominal storage \\
WDMUtil & Watershed Data Management database \\
WMA & Water Management Act \\
\hline
\end{tabular}




\section{Description of Hydrologic Simulation Program-FORTRAN (HSPF)}

Streamflow in the Taunton River Basin was simulated with HSPF, version 12 (Bicknell and others, 2000). HSPF was chosen because it produces detailed simulations of streamflow and water quality, and because it has been successfully used to study water-management issues in other basins in New England (Barbaro and Zarriello, 2006; Zarriello and Bent, 2004; Zarriello and Ries, 2000) and basin-scale water quality in other parts of the United States (Martin and others, 2001).

HSPF is a mathematical model designed to simulate the hydrology and water quality of a river basin; however, only the hydrologic-simulation capability of HSPF was used in this study. Runoff is quantified by the continuous simulation of hydrologic response to climatic and human stresses. In HSPF, a basin is represented by a group of hydrologically similar areas that are referred to as hydrologic response units (HRUs) that drain into a network of reaches (RCHRESs) consisting of streams, lakes, or reservoirs. The drainage area around each RCHRES is referred to as a subbasin. For each HRU and RCHRES, the model computes a water budget (inflows, outflows, and changes in storage) for each time step. A complete description of the processes involved in computing water budgets and required input model parameters is given in the HSPF User's Manual (Bicknell and others, 2000).

HRUs reflect areas of similar land use, surficial geology, and other factors deemed important to produce a similar hydrologic response to precipitation and evapotranspiration. HRUs are divided into pervious-area land segments (PERLNDs) and impervious-area land segments (IMPLNDs). These land segments are represented by zones, which represent storage volumes, and by processes, which move water between the zones. PERLNDs and IMPLNDs have zones that retain precipitation at the surface as interception storage or snowpack storage. All water that is not evaporated produces surface runoff from IMPLNDs. By contrast, PERLNDs allow excess precipitation to infiltrate into the subsurface, where storage volumes and processes are represented by upper, lower, and groundwater zones. Processes that control the rate of infiltration and change in subsurface storage make simulation of PERLNDs considerably more complex than simulation of IMPLNDs. In the model simulation, surface runoff from PERLNDs and IMPLNDs and subsurface discharge from PERLNDs are typically directed into reaches.

RCHRESs are model elements that represent a length of stream channel or reservoir. The downstream end of each RCHRES is referred to as a node. Nodes are typically placed to define channel segments with similar physical properties, such as reach segments with similar slope and width, junctions of tributary streams, lakes and reservoirs, and locations of data-collection sites. Nodes can be placed at other locations where estimates of streamflow are desired, such as upstream and downstream from municipal well fields, water diversions, or discharges of contaminants. The hydraulic characteristics used for kinematic wave routing of water in a RCHRES are defined by its storage-discharge properties specified in a function table (FTABLE) of the model input. The FTABLE characterizes the hydraulic properties of the reach by defining the relation between depth, storage, and discharge.

HSPF simulates numerous inflows to and outflows from a stream reach. Surface runoff can discharge to a reach from impervious and pervious surfaces. Infiltrated water can discharge to the reach through the subsurface as interflow, which is analogous to a fast-responding shallow subsurface flow, or from active groundwater, which is analogous to a slowresponding base-flow component, or, optionally, exit from an HRU as a deep groundwater flow that discharges outside of the basin. Inflow to a reach also can come from upstream reaches, direct precipitation, and other user-specified point sources such as treated wastewater. Volumetric outflow from a reach can be directed through five outflow exits (or gates). Up to three outflow exits were designated for each reach in the Taunton River Basin model. Water from the time series of total municipal and commercial/industrial withdrawals was directed through the first outflow exit in reaches with this type of withdrawal. Water from the time series of withdrawals for irrigation of cranberry bogs was directed through the second outflow exit in reaches with this type of withdrawal. Water was routed downstream through the third outflow exit in reaches with both types of withdrawals; in reaches with no withdrawals, a single outflow exit representing outflow to the downstream reach was specified.

\section{Input Data Used for the Model}

HSPF uses a watershed data management (WDM) file as a database. The WDM file efficiently stores input time-series data required for simulations and output time-series data generated by the model. Output time-series data can be generated for any component in the simulation process defined by the user, but streamflow time series are the primary output.

Dataset numbers (DSNs) and attribute information must exist in the WDM file to pass time-series data between the WDM file and the model. DSN numbers up to 100 were used to store measured climatic and streamflow time series. Data sets with numbers larger than 100 were used to store input withdrawal and return flow time series data and model-generated streamflow time series, and generally are organized by reach. The methods used to develop the climatic, withdrawal, return flow, and streamflow data time series for the HSPF model are described in the following sections.

\section{Climate}

Data from T.F. Green Airport in Warwick, R.I. (station no. 376698), and Taunton Municipal Airport in Taunton, Mass. (station no. 54777) (fig. 1), were used as input to the HSPF model. T.F. Green Airport is the closest first-order National 
Weather Service station (long-term hourly climate data for multiple parameters) to the basin.

Climatic data stored in the WDM file include precipitation, potential evapotranspiration, air temperature, dew-point temperature, solar radiation, cloud cover, and wind speed. Precipitation and potential evapotranspiration are required by HSPF to simulate the movement of water, and the remaining parameters are required to simulate the accumulation and melting of snow and ice. All these climate data, with the exception of solar radiation, were obtained from T.F. Green Airport in hourly time steps for the period January 1, 1960, to November 12, 2007. Hourly precipitation data from Taunton Municipal Airport were obtained for the period November 5, 1997, to March 12, 2008 (encompassing the streamflow calibration period), to calibrate the flow model and simulate streamflow with precipitation from a station in the basin.

The Northeast Regional Climate Center in Ithaca, N.Y., provides daily solar radiation computed from other climatic variables. WDMUtil, a utility software program for HSPF, was used to disaggregate the daily solar-radiation values to the hourly values needed for the snow calculations. The Jensen-Haise method (Jensen and Haise, 1963; Rosenberry and others, 2004) was used to calculate daily potential evapotranspiration. To remove seasonal bias in potential evapotranspiration losses, the monthly variable coefficients used in the Jensen-Haise computation were adjusted from default values during model calibration. The daily potential evapotranspiration values were disaggregated to the hourly values needed for the simulations.

Data gaps in the precipitation, air temperature, dewpoint temperature, and wind speed records were estimated by calculating the mean of the measured values bracketing the missing interval. Data gaps in the cloud cover record were estimated by linear interpolation between the measured values bracketing the missing interval. Roughly 15 percent of the climate data records were missing and most of the missing values occurred prior to 1980 . The longest continuous interval of missing data was 48 hours.

\section{Water Withdrawals}

The water withdrawals simulated in the model include (1) the groundwater and surface-water withdrawals for public water supply and commercial/industrial uses, and (2) groundwater and surface-water withdrawals for golf-course and cranberry-bog irrigation. The municipal and commercial/ industrial withdrawals are described in greater detail below. Irrigation withdrawals are described in detail in the following section. Private residential withdrawals were not represented in the model because a large fraction of withdrawn water is returned to the basin locally through onsite septic systems.

Detailed groundwater and surface-water withdrawal data for municipal and commercial/industrial withdrawals were obtained for the period 1997-2006 from the Annual Statistical Reports submitted by public-water suppliers to the
Massachusetts Department of Environmental Protection (MA DEP), and a database maintained by the MA DEP for Water Management Act (WMA) withdrawals. The 39 municipal and commercial/industrial withdrawals included in the model (including five withdrawals for golf-course irrigation that are described in detail in the following section) are shown in figure 1-1 and summarized in table 1-1. Of these withdrawals, 3 were known to be from surface water, 33 were known to be from groundwater, and the remaining 3 withdrawals for golf courses may have used both groundwater and surface-water sources, but specific information on sources was not available. At five sites, multiple wells were combined and treated as a single source, mainly because only a total withdrawal rate was reported by the supplier (table 1-1). Approximately 10 permitted withdrawals in the impaired-reach model area were not included in the model because either the well was inactive or the permit was for a minor commercial withdrawal.

Withdrawals typically were reported as monthly volumes. Daily rates were available for out-of-basin transfers from Monponsett Pond to Silver Lake for the City of Brockton water-supply system. Periods of missing record because of the unavailability of withdrawal records or equipment problems were estimated. Averages from volumes bracketing the period of missing record or average volumetric withdrawals for the period of missing record calculated from other years were used to estimate gaps in the record. Ten municipal or commercial/industrial withdrawals in the impaired-reach model area had periods of missing record requiring estimation. After estimating missing data, monthly volumes were disaggregated to daily withdrawals by dividing by the number of days in the month. For time-varying groundwater withdrawals, streamflow depletion was computed from withdrawal records, as described in the Streamflow Depletion section below.

\section{Irrigation Withdrawals}

Irrigation withdrawals were calculated for the five golf courses and the cranberry bogs in the impaired-reach model area (table 1-1). For the golf courses, certain information, such as the number of irrigated acres, the source of irrigation water (for example, groundwater or surface-water withdrawals), and the volumes of water used for irrigation, was not available. However, withdrawal and irrigated acreage data were available for six courses in the Blackstone River Basin, and the measured water use for these courses, reported as the total annual volumes of water, were used to calibrate a procedure for computing daily irrigation withdrawals (Barbaro and Zarriello, 2006).

Daily irrigation withdrawals were computed from a daily irrigation demand determined from antecedent climatic conditions (precipitation and potential evapotranspiration [PET]). Based on the Blackstone model calibration, applied irrigation (and hence withdrawals from the basin) were assumed to be 50 percent of the daily irrigation demand, where the irrigation demand was computed as the difference between the total precipitation in the previous 5 days and the total PET in 


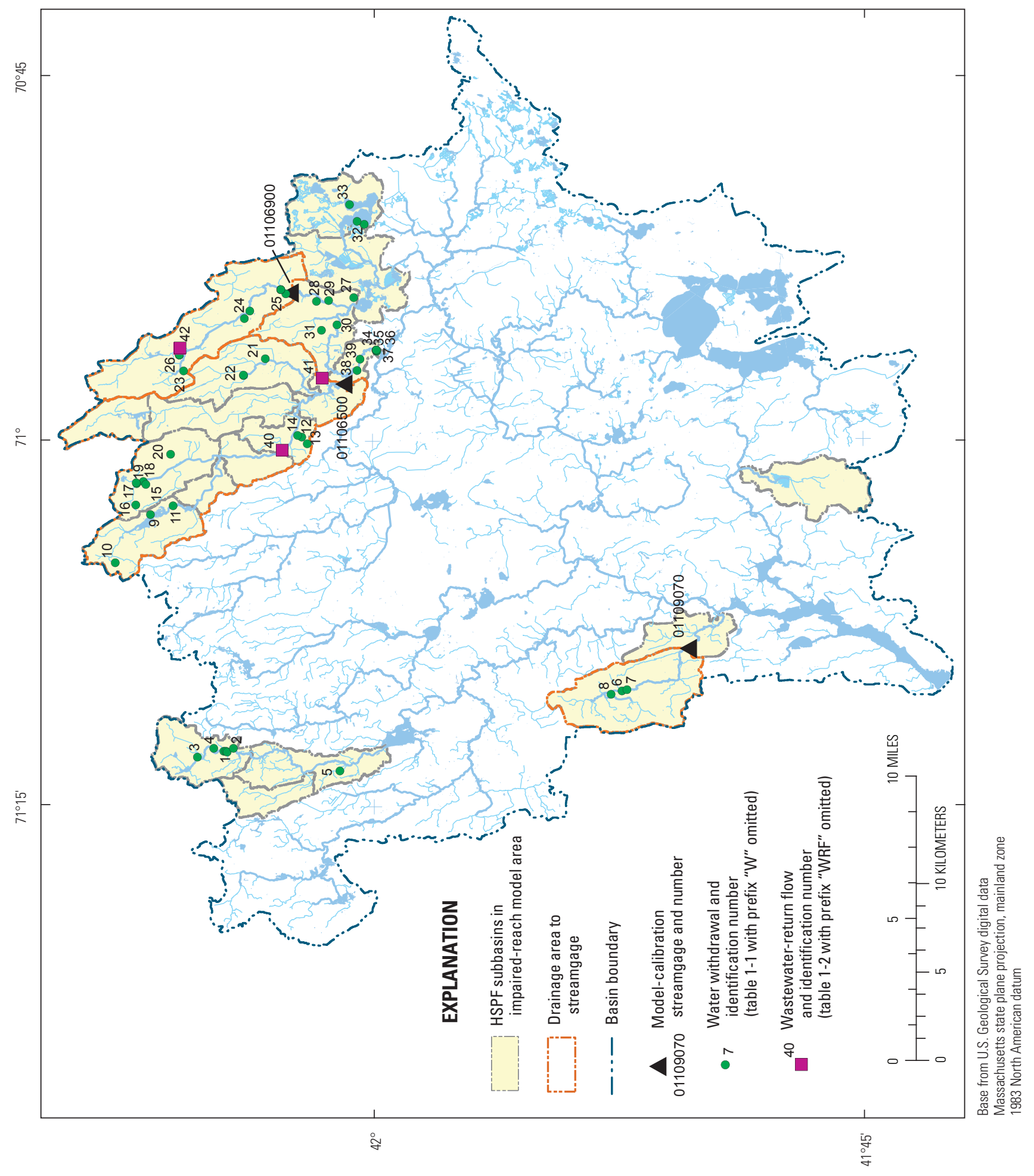




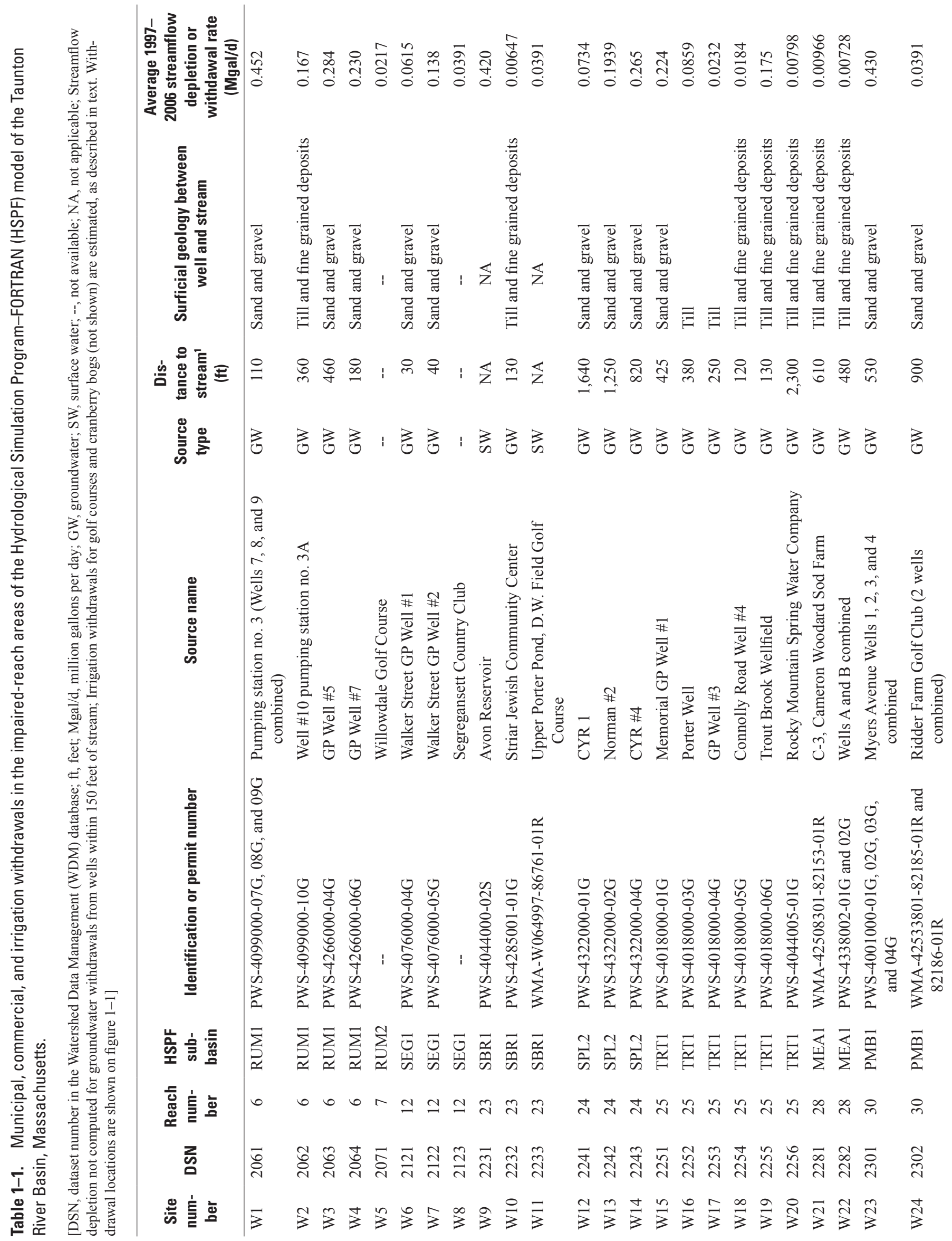




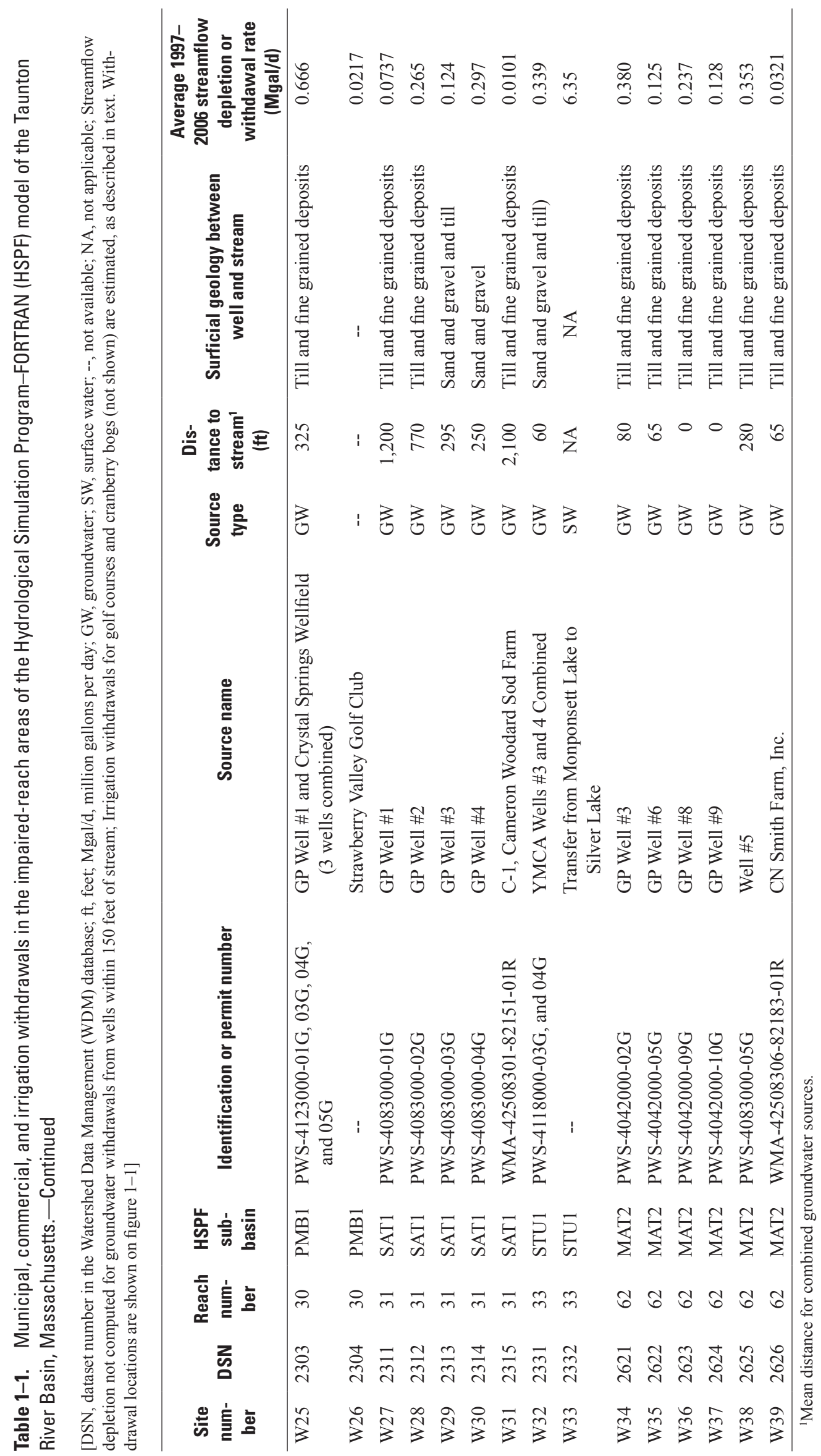


the previous 2 days. If the total precipitation in the previous 5 days exceeded the total PET in the previous 2 days, irrigation was not applied. If, on the other hand, total PET exceeded total precipitation, 50 percent of the difference was applied as irrigation for that day. This approach yielded temporally variable irrigation controlled by climate. For example, there were typically long (2-3 weeks) stretches during the summer when there was no irrigation because of wet conditions. Although approximate, using climatic data to estimate periods of irrigation is more realistic than applying irrigation uniformly on a daily basis throughout the irrigation season. To develop irrigation time series, it was assumed that irrigation was applied at a constant rate for 24 hours on each day when irrigation took place, and that irrigation only took place from April through November (210 days). The methodology is described in detail in Barbaro and Zarriello (2006).

To estimate irrigation withdrawals for the golf courses in the Taunton River Basin, the number of irrigated acres was assumed to be 25 acres for the 9-hole courses (Willowdale Golf Course and Strawberry Valley Golf Course) and 45 acres for the 18-hole courses (Ridder Farm Golf Club, D.W. Field Golf Course, and Segreganset Country Club). Consequently, one irrigation withdrawal time series was used for all 9-hole courses and another for all 18-hole courses. In addition, because it was not known whether groundwater, surface water, or both were used for irrigation, streamflow depletion, if appropriate, could not be computed, and estimated irrigation withdrawals were removed directly from stream reaches. In the HSPF model, withdrawals for golf-course irrigation were assumed to be 100 percent consumed (that is, none of the withdrawn water was returned to the basin).

The approach described above for golf courses was used to compute irrigation withdrawals for cranberry bogs. Four subbasins in the impaired-reach model area contain cranberry bogs: reach 31, Satucket River at East Bridgewater; reach 33, Stump River above outlet of Monponsett Lake; reach 34, Stump River above confluence with Satucket River; and reach 56, unnamed tributary to Cedar Swamp River (fig. 1-2). Withdrawals were computed for the total acreage of cranberry bogs in these subbasins (44 acres in reach 31; 340 acres in reach 33; 701 acres in reach 34; and 183 acres in reach 56); withdrawals for individual bogs were not simulated. The calibrated irrigation procedure produced seasonal water-application volumes in the range of 8-15 inches (in.) (volumes expressed as volume applied per unit area) for the period 1996-2006, with higher volumes being applied during dry summers. These volumes are consistent with summer application rates for bog irrigation and cooling for Massachusetts cranberry bog farming (Carlson and Lyford, 2004). Withdrawals for cranberrybog irrigation were assumed to be 100 percent consumed (that is, none of the withdrawn water was returned to the basin). Because information on the specific sources of the irrigation water was not available, it was assumed that irrigation withdrawals were taken directly from surface water in the reach.

Other aspects of cranberry-bog water use, such as the flooding and draining of bogs for frost protection and harvesting, were not represented in the HSPF model. These diversions move water from surface-water or groundwater storage to bogs and stream channels and potentially affect the timing of seasonal runoff volumes and rates (that is, periods of lower flows may occur when surface water is being withheld in storage and periods of higher flows may occur when individual bogs are drained), but do not result in an appreciable loss of water from the subbasin on an annual or decadal time scale. Moreover, the schedules for these diversions are specific to individual bogs and difficult to generalize for a subbasin. Consequently, a simplified approach in which only the water applied as irrigation during the growing season, and lost to the atmosphere through evapotranspiration, was explicitly simulated in the model.

\section{Streamflow Depletion by Groundwater Withdrawals}

Streamflow depletion was determined for time-varying groundwater withdrawals from wells greater than 150 feet $(\mathrm{ft})$ from the nearest stream by use of the program STRMDEPL (Barlow, 2000). For wells near streams, streamflow depletion and actual withdrawal time series are nearly identical. STRMDEPL produces a daily time series of the total streamflow depletion computed from the reported withdrawal record. Total streamflow depletion has two components: captured (or intercepted) discharge, which is groundwater that would have discharged to the stream had the well not been pumped, and induced infiltration, which is streamflow drawn out of the channel to the aquifer. Thus, the total volume of streamflow depletion under long-term, steady-state conditions is very close to the total volume pumped from the well; the main effect of STRMDEPL is to dampen the magnitude and timing of the time-varying pumping rate, which results from the diffusivity of the aquifer $(\mathrm{T} / \mathrm{S}$, where $\mathrm{T}$ is the transmissivity and $\mathrm{S}$ the storativity or specific yield) and the distance of the well from the stream. STRMDEPL is based on several simplifying assumptions: the aquifer is homogeneous, isotropic and semi-infinite in areal extent; both the stream and the well fully penetrate the aquifer; and the stage of the stream remains constant with time. To simulate long-term operation and produce initial streamflow depletion similar to the pumping rate at the start of the calibration period, wells were allowed to pump for 5,000 days prior to the analysis.

STRMDEPL provides a direct measure of streamflow depletion caused by groundwater withdrawals. Therefore, although the actual locations of individual wells were used to calculate streamflow depletion, the withdrawals that result from the calculation are taken directly from the stream reach in the HSPF model. Streamflow depletion was computed for withdrawals from wells completed in unconsolidated deposits; none of the wells in the impaired-reach model area were known to be completed in bedrock. Most of the high-capacity wells are in sand and gravel aquifers near streams and induce infiltration from streams to improve yields. The median distance of the wells in the impaired-reach model area to the nearest stream was about $300 \mathrm{ft}$ (table 1-1). 


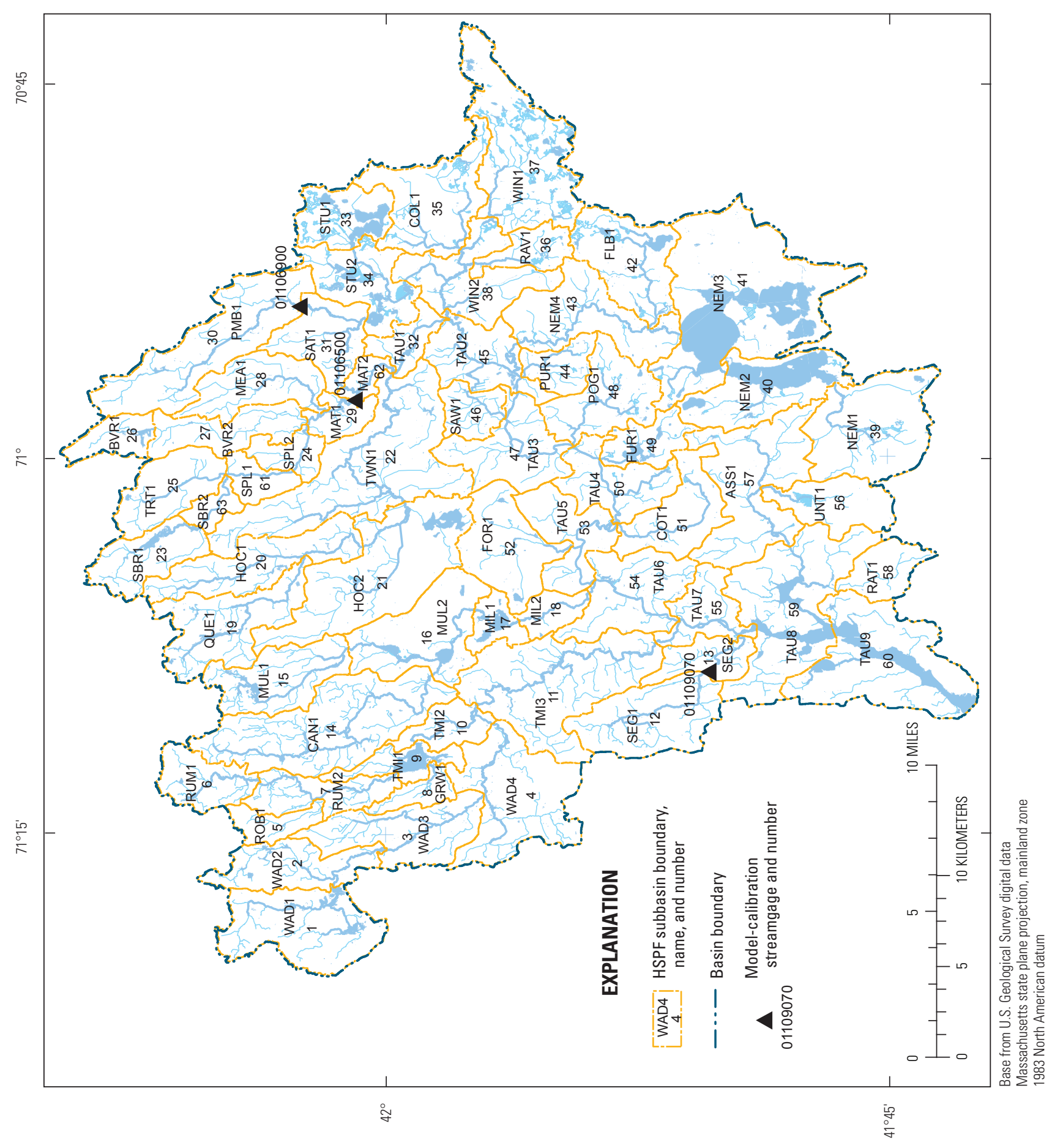


Lithologic information was not readily available for most of the wells, so the transmissivity of the unconsolidated deposits between the well and stream was determined from a transmissivity contour map developed by Lapham (1988). Based on these mapped transmissivities, values of $670,2,670$, and 4,500 square feet per day $\left(\mathrm{ft}^{2} / \mathrm{d}\right)$ were used in streamflow depletion calculations. A transmissivity of $100 \mathrm{ft}^{2} / \mathrm{d}$ was used for wells completed in areas dominated by till deposits. Dividing by a specific yield of 0.25 , diffusivities ranged from 400 to $18,000 \mathrm{ft}^{2} / \mathrm{d}$. Streams underlain by sand-and-gravel aquifers tend to have coarse streambed materials that do not substantially limit the flux of water across the bed. The streambank leakance term was therefore assigned a value of 0 , indicating that the bed of the stream has the same hydraulic properties as the aquifer, which is equivalent to assuming that low-permeability streambed deposits that may impede flow are not present. All daily values were disaggregated again to hourly values to match the simulation time step.

\section{Wastewater-Return Flows}

Wastewater-return-flow rates for 1997-2006 were obtained from the MA DEP and the Brockton Advanced Water Reclamation Facility (AWRF). The return flows in the impaired-reach model area include (1) municipal wastewaterreturn flows for the City of Brockton, (2) wastewater-return flows for East Bridgewater Schools, (3) filter-backwash return flows from the Myers Avenue water-treatment plant for the towns of Abington and Rockland (fig. 1), and (4) return flows of septic effluent from residential areas with public-water supplies and private sewers (septic systems). Municipal and commercial/industrial return flows are described in greater detail below. A discussion of how the septic-effluent discharges are treated in the model is provided next in the Representation of the Basin section.

The three municipal and commercial/industrial wastewater-return flows in the impaired-reach areas are shown in figure A1 and table A2. Eight additional commercial sites in the impaired-reach areas with National Pollutant Discharge Elimination System (NPDES) discharge permits were not included in the model because the sites were apparently inactive during the calibration period, return-flow information could not be located, or return-flow rates were very low. The time intervals and amount of missing data varied considerably among the three return flows in the model, and required various degrees of processing. Return flows from Brockton AWRF were reported as daily rates and there was no missing data; the return flow rate averaged 20.2 million gallons per day (Mgal/d) for the period 1997-2006. Filter-backwash return flows from the Myers Avenue Water Treatment Plant were reported as maximum daily flows for most months during the period 2001-2006; a nearly constant daily rate of $0.063 \mathrm{Mgal} / \mathrm{d}$ was reported, so this rate was used as an average value for the entire 1997-2006 calibration period. Return flows from East Bridgewater Schools were reported as monthly volumes for 2000, 2001, and 2003; average monthly volumes for these years were used to estimate monthly volumes for the other years in the calibration period. To format the return flow data for input to the WDM file, annual or monthly return flows were disaggregated to daily values by dividing by the number of days in the reported period. All daily values were disaggregated again to hourly values to match the simulation time step.

\section{Streamflow}

The three streamgages in the impaired-reach model area with periods of continuous record include the Segreganset River near Dighton (station no. 01109070), Matfield River at Elmwood, East Bridgewater (station no. 01106500), and Poor Meadow Brook at South Hanson (station no. 01106900) (table 1-3; fig. 1-3). Simulated flows were calibrated to measured or estimated flows at these stations. Flows at the other partial-record stations in the impaired-reach model area were measured infrequently and only during low-flow periods, and therefore were not suitable for model calibration. There are three other streamgages in the basin with long-term, continuous record (Wading River near Norton, station no. 01109000; Threemile River at North Dighton, station no. 01109060; and Taunton River at Titicut Street near Bridgewater, station no. 01108000) that are outside of the impaired-reach model area.

Table 1-2. Wastewater-return flows in the impaired-reach areas of the Hydrological Simulation Program-FORTRAN (HSPF) model of the Taunton River Basin, Massachusetts.

[DSN, dataset number in the Watershed Data Management (WDM) database; Mgal/d, million gallons per day; Return-flow locations shown on figure 1-1]

\begin{tabular}{ccccclc}
\hline $\begin{array}{c}\text { Site } \\
\text { number }\end{array}$ & DSN & $\begin{array}{c}\text { Reach } \\
\text { number }\end{array}$ & $\begin{array}{c}\text { HSPF } \\
\text { subbasin }\end{array}$ & $\begin{array}{c}\text { Identification or } \\
\text { permit number }\end{array}$ & Source name & $\begin{array}{c}\text { Average } \\
\text { 1997-2006 rate } \\
\text { (Mgal/d) }\end{array}$ \\
\hline WRF40 & 3241 & 24 & SPL2 & NP-MA0101010-001A & Brockton Advanced Water Reclamation Facility \\
WRF41 & 3291 & 29 & MAT1 & NP-MA0022446-001A & East Bridgewater Schools & 0.00643 \\
WRF42 & 3301 & 30 & PMB1 & NP-MAG640009-0000 & Myers Avenue Water Treatment Plant (filter backwash) & 0.0630 \\
\hline
\end{tabular}




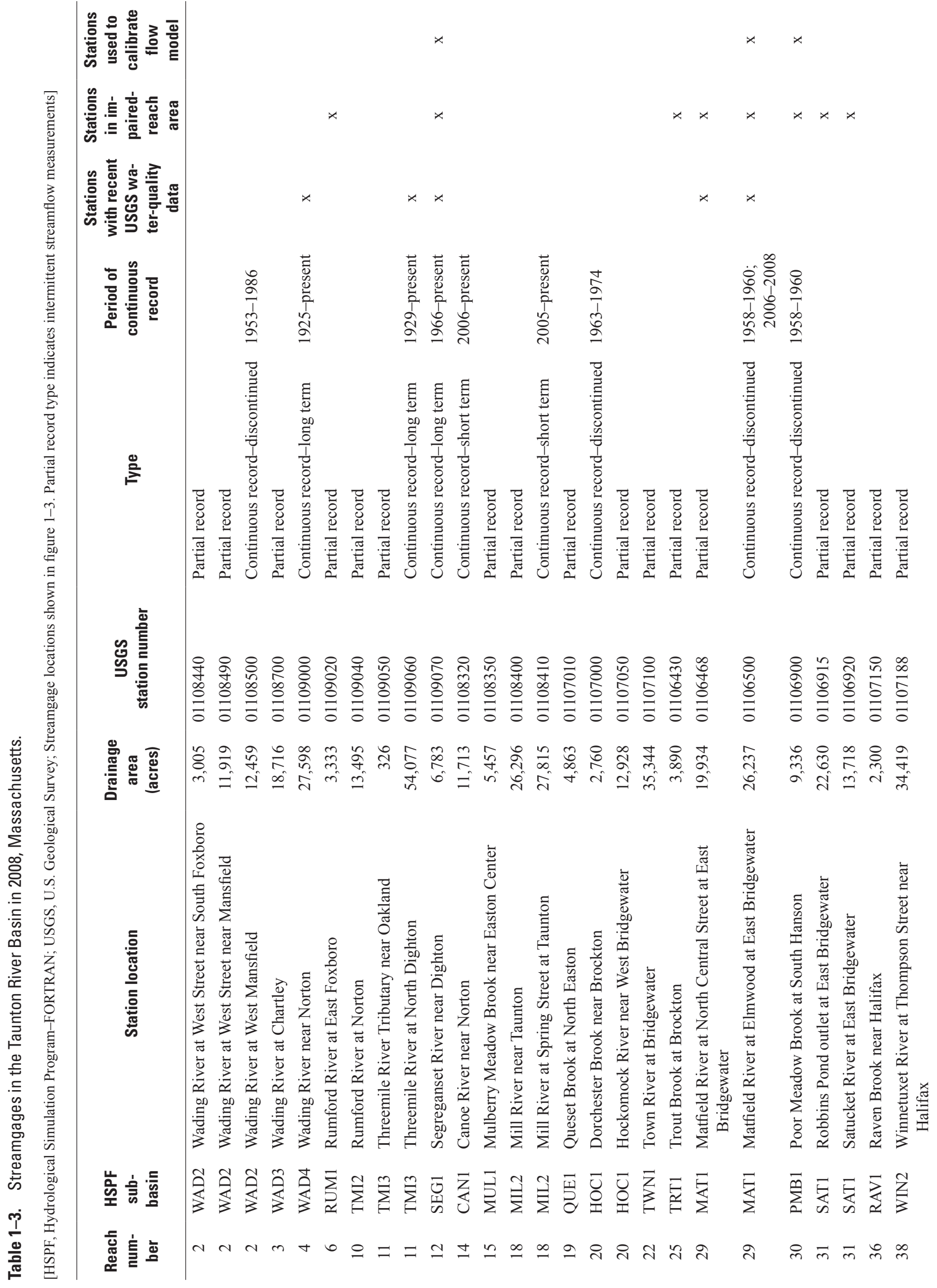




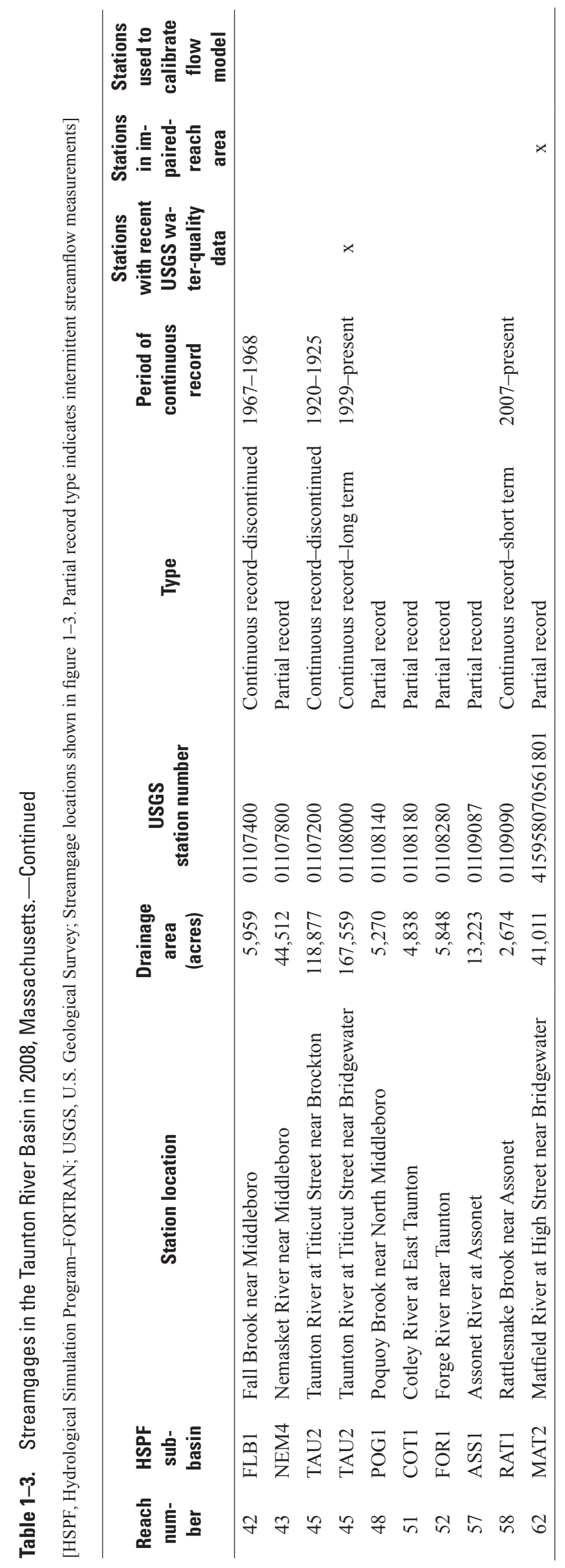




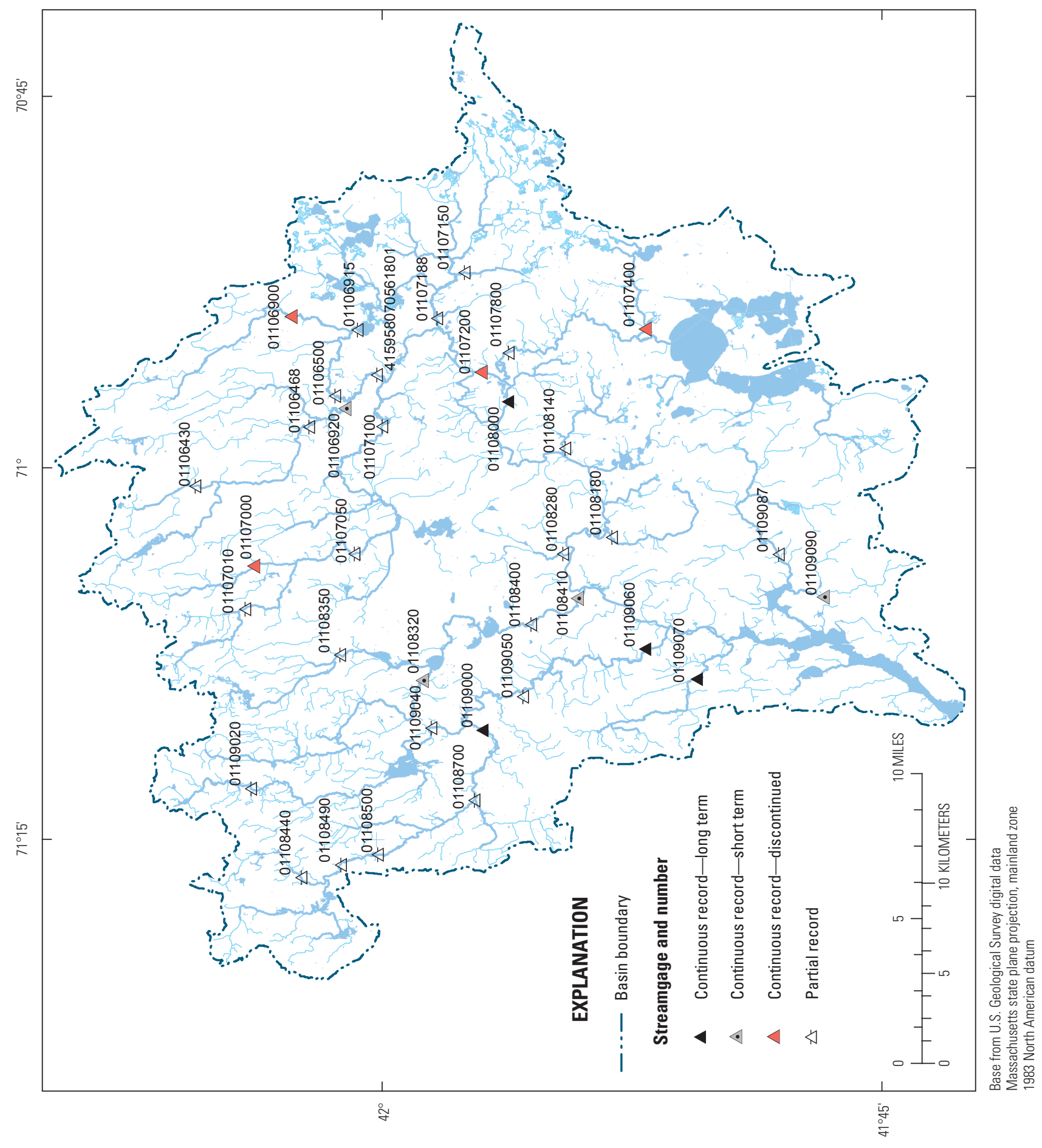


Flow was measured continuously at the Segreganset River near Dighton station for the entire calibration period of 1997-2006. At the other two stations (Matfield River at Elmwood, East Bridgewater and Poor Meadow Brook at South Hanson), flows were not measured continuously for this period; consequently, a record-extension technique, a mathematical procedure known as Maintenance of Variance Extension, type 1 (MOVE.1) (Hirsch, 1982), was used to calculate flows for the calibration period. The MOVE.1 analysis was done with the computer program Streamflow Record Extension Facilitator (SREF), version 1.0 (Granato, 2009). MOVE. 1 transfers the statistical characteristics of the index station, such as distribution shape, seasonality, and amount of serial correlation, to the station being used for calibration (also referred to as the project station) requiring flow estimation. To apply this method, the logarithms of daily mean streamflow at a project station were compared with the same-day daily mean streamflow at the selected index stations for the common period of record. Index stations were selected based on (1) the correlation and linearity of the log-transformed data, and (2) visual inspection of the agreement between the measured and computed flows for the common period of record. Following application of MOVE.1 to the period of common record, flows at the index stations were used to compute daily mean streamflows at the project station for the period 1997-2006. If flows at the project station correlated equally well with more than one index station, all of the highly correlated index stations were used in the analysis. In these cases, the daily mean streamflow at the project station was computed as the weighted average of the daily mean streamflows calculated from the index stations. The mean square errors between computed and measured streamflows were used as weighting factors.

At the Poor Meadow Brook at South Hanson station, continuous record was available for the period 1958-60. Streamflow at this station was estimated from measured flows at two long-term index stations: Taunton River at Titicut Street, Bridgewater (station no. 01108000) and East Branch of the Neponset River at Canton (station no. 01105500). Correlation coefficients between logarithms of measured and predicted flows for the period of common record were 0.9492 (station no. 01108000) and 0.9145 (station no. 01105500). During 1958-60, there were no major water withdrawals in the drainage area (reach 30) to the Poor Meadow Brook station. Because the MOVE.1 equation was based on 1958-60 flow data, recent water use (tables $1-1$ and 1-2) is not reflected in the estimated streamflow for 1997-2006. For this reason, all water withdrawals and wastewater-return flows in the drainage area were removed from the model for the calibration period to compute model-fit statistics and assess model performance (see the Flow Calibration section of the appendix).

At the Matfield River streamgage, continuous streamflow data were available for the period December 15, 2006, through September 30, 2007. Streamflow at this location is strongly affected by wastewater-return flows from the Brockton AWRF and the amount of upstream urban land use. Consequently, to enable correlations with index stations not strongly affected by wastewater-return flows, Brockton effluent flows were subtracted from the measured streamflow record at the Matfield station prior to estimating flows with MOVE.1. This approach was found to provide better correlations with flows from the index stations. Streamflow at the Matfield station was estimated from measured flows at four index stations: Threemile River at North Dighton (station no. 01109060), East Branch of the Neponset River at Canton (station no. 01105500), Aberjona River at Winchester (station no. 01102500), and Pawtuxet River at Cranston, R.I. (station no. 01116500). Correlation coefficients between logarithms of measured and predicted flows for the period of common record were 0.9340 (station no. 01109060), 0.9573 (station no. 01105500), 0.9188 (station no. 01102500), and 0.9192 (station no. 01116500). To develop the final estimated streamflow time series, measured daily wastewater-return flows from the Brockton AWRF were added to the weighted MOVE.1 estimates of daily streamflow for the period 1997-2006.

The accuracy of these record-extension techniques is determined by the degree of correlation between the daily mean streamflow at the project and index stations for the common period of record, the accuracy of the measured streamflows, and the range of measured streamflow at the project stations (Zarriello and Bent, 2004). Because of the short period of record at the Matfield River at Elmwood station, a wide range of flow conditions was not measured, and estimated flows at both high and low flows are less accurate than other flows. Because data were not collected in recent years the Poor Meadow Brook and South Hanson station (1958-60), estimated flows do not accurately reflect current conditions. In addition, flow regulation may affect specific ranges of flows in the project and index stations, leading to additional error in the estimated record.

\section{Representation of the Basin}

The physical and spatial representation of the basin is defined by the combination of HRUs (PERLNDs and IMPLNDs), their contributing area to a reach, and the linkage of one stream reach to another. The process of defining HRUs, their linkage to reaches, and the linkage of reaches to each other often is referred to as the discretization of a basin. A geographic-information system (GIS) was used to discretize the Taunton River Basin. The information used in the discretization process included Massachusetts Geographic Information System (MassGIS) 1:24,000-scale surficial geology, 1:25,000-scale land use, and 1:12,000-scale wetlands data layers (Massachusetts Office of Geographic Information, 2008a-c); 1:25,000-scale USGS topographic data and 1:5,000scale digital elevation model (DEM) data; and census data for determining population and residential areas served by onsite septic systems (Massachusetts Office of Geographic Information, 2008d). 


\section{Surficial Geology}

For HRU delineation, the MassGIS surficial-geology data layer (Massachusetts Office of Geographic Information, 2008b) was simplified from five types of material (sand and gravel, flood-plain alluvium, till or bedrock, large sand deposits, and fine-grained deposits) into two types on the basis of permeability and storage characteristics. Areas underlain by fine-grained deposits and flood-plain alluvium were combined with till and referred to as "till and fine-grained stratified deposits" in this report. Areas underlain by large sand deposits were combined with sand and gravel deposits and referred to as "sand and gravel deposits." The generalized surficialgeology data layer indicates that 44 percent of the basin is underlain by sand and gravel deposits. The remaining 56 percent of the basin is underlain by till and fine-grained stratified deposits, of which 36 percent is till, 7 percent is fine-grained deposits, and 13 percent is flood-plain alluvium. Generalized surficial geology is shown in figure 3 .

\section{Land Use and Land Cover}

The MassGIS data layer of land use in 1999 has 37 landuse categories interpreted from 1:25,000-scale aerial photography (Massachusetts Office of Geographic Information, 2008a). The minimum mapping unit (resolution) was 1 acre. This data layer was intersected with the MassGIS wetlands data layer, which has 28 wetland categories interpreted from 1:12,000-scale aerial photography taken from 1990 to 2000 (Massachusetts Office of Geographic Information, 2008c). To represent land use in the model, the detailed land use and land cover (LULC) layer was aggregated to form 10 general categories: (1) commercial-industrial-transportation, (2) highdensity residential, (3) medium- to low-density residential, (4) open nonresidential, (5) forest, (6) forested wetlands, (7) nonforested wetlands, (8) agriculture, (9) cranberry bogs, and (10) open water (fig. 2).

The generalized land-use data layer indicates that about 37 percent of the basin was forested in 1999, excluding forested wetlands. If forested wetlands are included in the forest category, 52 percent of the basin was forested. An additional 7 percent of the basin was classified as open, nonresidential land. This mixed category includes participation and spectator recreational spaces such as golf courses and ball parks, urban open spaces such as parks and cemeteries, mining operations, and landfills. Agricultural land, including orchards and nurseries, pasture, and cropland, composed 5 percent of the basin area. Cranberry bogs composed about 2 percent of the basin area. Bogs are concentrated in the eastern part of the basin. Wetlands, including forested and nonforested, composed 18 percent of the basin area, of which 15 percent was forested wetlands and 3 percent was nonforested wetlands. Approximately 4 percent of the basin was classified as commercialindustrial-transportation land. This mixed category includes all roads and other transportation facilities, industrial facilities, commercial facilities such as shopping malls and general urban space, wastewater-treatment plants, and junkyards. About 5 percent of the basin was classified as open water, which includes ponds, reservoirs, and the channels of the larger rivers in the basin.

The remaining 22 percent of the basin was classified as residential, of which 19 percent was medium- to low-density residential and 3 percent was high-density residential. To obtain these percentages, the four Massachusetts residential land-use categories (1) multifamily, (2) smaller than $1 / 4$-acre lots, (3) $1 / 4$ - to $1 / 2$-acre lots, and (4) larger than $1 / 2$-acre lots were consolidated by combining categories (1) and (2) to form the high-density residential category and (3) and (4) to form the medium- to low-density residential category. Grouped in this manner, medium- to low-density residential areas in the HSPF model represent single-family households on lots with areas equal to or larger than $1 / 4$ acre.

Each of the four Massachusetts residential land-use categories was assigned an average household density per acre based on lot size (eight, six, three, and one households per acre for residential categories 1 through 4, respectively), and an average population density per acre using an average of 2.5 people per household from 2000 census data. Average household and population densities per acre for the two aggregated residential land-use categories in the HSPF model were then calculated as weighted averages of the densities in the four Massachusetts categories. The high-density residential area consists of 22.3 percent multifamily and 77.7 percent smaller than $1 / 4$-acre lots, whereas the medium- to low-density residential areas consist of 50.9 percent $1 / 4$-acre to $1 / 2$-acre lots and 49.1 percent larger than $1 / 2$-acre lots. Using these percentages, the high-density residential areas in the HSPF model contain 6.4 households per acre on average, and the medium- to lowdensity residential areas contain 2.0 households per acre on average. Based on an average occupancy rate of 2.5 people per household, these housing densities equate to 16.1 people per acre in high-density residential areas and 5.0 people per acre in medium- to low-density residential areas. The total population in the basin calculated from these residential population densities and corresponding areas in the basin was 484,800 . The total population in the basin in 2000 estimated from United States' census block data was 440,000. The percent difference between these population estimates is 9.7 percent, indicating that residential land use and population are reasonably well represented in the model.

\section{Hydrologic Response Units}

HRUs were created by combining the generalized surficial-geology and land-use data layers. These combinations were grouped further on the basis of the importance of the underlying surficial geology. For example, for wetlands and cranberry bogs, differences in the underlying surficial geology were deemed to be relatively unimportant. Consequently, forested wetland, nonforested wetland, and cranberry bog areas 
underlain by till and fine-grained stratified deposits and sand and gravel deposits were combined to form single HRUs. As described in greater detail below, additional HRUs were created from 1990 census block data to represent residential areas served by onsite septic systems (Massachusetts Office of Geographic Information, 2008d). Processing the surficial-geology and land-use data in this manner produced 19 PERLNDs and 2 IMPLNDs. As described in greater detail below, wetlands were treated as storage components (also referred to as virtual reaches) rather than PERLNDs in selected subbasins. Open water was represented in the stream reach (RCHRES) section of the model. A general description and total areas of the 19 PERLND and 2 IMPLND types in the Taunton River Basin HSPF model in the basin are given in table 1-4.

\section{Effective Impervious Areas (IMPLNDs)}

The fraction of total impervious area that drains directly to streams is referred to as hydrologically effective impervious areas (EIA). In HSPF, IMPLNDs represent the EIA of the basin. Impervious areas that drain to pervious areas (hydrologically noneffective impervious areas) are incorporated into the PERLNDs. Estimates of EIA were determined as percentages of the areas of the developed land-use categories in the 37-category Massachusetts land-use data layer. Developed land-use categories were placed in five groups, each with an associated percentage of EIA (table 1-5). By using the detailed State data layer to estimate the EIA of the basin, a more accurate estimate of IMPLND area was obtained. The land-use groupings

Table 1-4. Definitions and areas of hydrologic response units for the Hydrological Simulation Program-FORTRAN (HSPF) model of the Taunton River Basin, Massachusetts.

[HRU, hydrologic response unit; EIA, effective impervious area; s\&g, sand and gravel; t\&fg, till and fine-grained stratified deposits; --, not applicable]

\begin{tabular}{|c|c|c|c|c|c|}
\hline HRU & $\begin{array}{l}\text { Surficial } \\
\text { geology }\end{array}$ & $\begin{array}{l}\text { Area in basin } \\
\text { before calcu- } \\
\text { lation of EIA } \\
\text { (acres) }\end{array}$ & $\begin{array}{l}\text { Area in basin } \\
\text { after calcula- } \\
\text { tion of EIA } \\
\text { (acres) }\end{array}$ & $\begin{array}{l}\text { Final } \\
\text { percentage } \\
\text { of basin } \\
\text { area }\end{array}$ & Land use \\
\hline PERLND 1 & s\&g & 51,689 & 51,689 & 15.1 & Forest \\
\hline PERLND 2 & $s \& g$ & 13,396 & 12,825 & 3.8 & Open nonresidential \\
\hline PERLND 3 & s\&g & 16,772 & 16,034 & 4.7 & Medium- to low-density residential \\
\hline PERLND 5 & $\mathrm{~s} \& \mathrm{~g}$ & 4,814 & 4,602 & 1.3 & Medium- to low-density residential, private wells and septic \\
\hline PERLND 6 & s\&g & 4,010 & 3,396 & 1.0 & High-density residential \\
\hline PERLND 7 & s\&g & 8,241 & 2,825 & 0.8 & Commercial-industrial-transportation \\
\hline PERLND 8 & s\&g & 8,510 & 8,510 & 2.5 & Agriculture \\
\hline PERLND 12 & $\mathrm{t} \& f g$ & 11,527 & 11,020 & 3.2 & Medium- to low-density residential, public water and septic \\
\hline PERLND 13 & t\&fg & 3,790 & 3,624 & 1.1 & Medium- to low-density residential, private wells and septic \\
\hline PERLND 14 & $\mathrm{t} \& f g$ & 4,702 & 4,000 & 1.2 & High-density residential \\
\hline PERLND 15 & t\&fg & 6,782 & 2,320 & 0.7 & Commercial-industrial-transportation \\
\hline PERLND 16 & t\&fg & 10,094 & 10,094 & 3.0 & Agriculture \\
\hline PERLND 17 & Combined & 5,643 & 5,643 & 1.7 & Cranberry bogs \\
\hline PERLND 18 & Combined & 50,867 & 50,867 & 14.9 & Forested wetland \\
\hline \multirow[t]{2}{*}{ PERLND 19} & Combined & 10,000 & 10,000 & 2.9 & Nonforested wetlands \\
\hline & -- & 17,460 & 17,460 & 5.1 & Open water \\
\hline
\end{tabular}


Table 1-5. Effective impervious area by developed land-use type for the Hydrological Simulation Program-FORTRAN (HSPF) model of the Taunton River Basin, Massachusetts.

\begin{tabular}{|c|c|c|c|}
\hline Land-use classification & $\begin{array}{l}\text { Area in basin } \\
\quad \text { (acres) }\end{array}$ & $\begin{array}{l}\text { Percentage of area } \\
\text { that is effective } \\
\text { impervious }\end{array}$ & $\begin{array}{c}\text { Effective } \\
\text { impervious area } \\
\text { (acres) }\end{array}$ \\
\hline Commercial development: & 15,433 & 64 & 9,877 \\
\hline \multicolumn{4}{|l|}{ Shopping centers } \\
\hline \multicolumn{4}{|l|}{ Heavy and light industrial facilities } \\
\hline \multicolumn{4}{|l|}{ Roads, airports, railways } \\
\hline High-density residential development: & 1,973 & 18 & 355 \\
\hline \multicolumn{4}{|l|}{ Multifamily residential } \\
\hline Medium-high density residential development: & 6,863 & 14 & 961 \\
\hline \multicolumn{4}{|l|}{ Smaller than 1/4-acre residential lots } \\
\hline Medium-density mixed development: & 77,355 & 5 & 3,868 \\
\hline \multicolumn{4}{|l|}{ 1/4-acre to $1 / 2$-acre residential lots } \\
\hline \multicolumn{4}{|l|}{ Larger than $1 / 2$-acre residential lots } \\
\hline \multicolumn{4}{|l|}{ Water and wastewater-treatment facilities, landfills, and junkyards } \\
\hline \multicolumn{4}{|l|}{ Recreational facilities } \\
\hline Low-density mixed development: & 1,843 & 2 & 37 \\
\hline \multicolumn{4}{|l|}{ Urban open space, parks, cemetaries } \\
\hline Total: & 103,467 & & 15,098 \\
\hline
\end{tabular}

used to compute the EIA differed slightly from the groupings used to define the land-use categories in the model. Generally, EIA was determined by removing area from the various LULC categories that compose the open nonresidential, residential, and commercial-industrial-transportation HRUs.

The initial percentages of impervious area for various developed land-use types were obtained from similar land-use types reported by Alley and Veenhuis (1983). The final percentages of EIA were obtained primarily by visual inspection of the overall responsiveness of the hydrograph to precipitation in the developed parts of the basin, and also by calibration of small summer storms that are considered to generate runoff mostly from effective impervious areas (Zarriello and Ries, 2000). The percentages used for the Blackstone River Basin HSPF model (Barbaro and Zarriello, 2006) were found to provide reasonable simulation results based on the criteria cited above. Two IMPLND types were used in the model: IMPLND associated with mixed commercial development (IMPLND 30), and IMPLND associated with residential development and urban open space (IMPLND 31). Hydrologically, these two IMPLNDs are similar, but they were given unique HRUs for possible future water-quality simulations.
About 30 percent of the basin is classified as developed, but the total EIA was estimated to be 4.4 percent of the basin area (table 1-4). The EIA as a percentage of model subbasin area ranged from about 19 percent for the relatively developed subbasins around the cites of Brockton and Taunton to less than 1 percent for undeveloped subbasins in the rural parts of the basin. The EIA as a percentage of the total drainage area to the streamgages used for flow calibration are 9.2 percent for the Matfield River station (station no. 01106500), 5.1 percent for the Poor Meadow Brook station (station no. 01106900), and 1.8 percent for the Segreganset River station (station no. 01109070).

\section{Pervious Areas (PERLNDs)}

Pervious surfaces that allow infiltration and impervious areas that drain to pervious areas are represented in HSPF as PERLNDs. Pervious areas in the basin are represented by eight PERLNDs overlying till and fine-grained stratified deposits, eight PERLNDs overlying sand and gravel, and three PERLNDs overlying both surficial-geology types combined 
(table A4). Two HRUs represent open, nonresidential space (PERLND 2 overlying sand and gravel and PERLND 10 overlying till and fine-grained stratified deposits), two HRUs represent forested areas (PERLND 1 overlying sand and gravel; PERLND 9 overlying till and fine-grained stratified deposits), six HRUs represent medium- to low-density development with different water-supply and wastewater-disposal systems (PERLNDs 3, 4, and 5 overlying sand and gravel and PERLNDs 11, 12, and 13 overlying till and fine-grained stratified deposits), two HRUs represent high-density development with all water-supply and wastewater-disposal systems combined (PERLND 6 overlying sand and gravel and PERLND 14 overlying till and fine-grained stratified deposits), two HRUs represent commercial-industrial transportation (PERLND 7 overlying sand and gravel and PERLND 15 overlying till and fine-grained stratified deposits), and two HRUs represent agricultural land use (PERLND 8 overlying sand and gravel and PERLND 16 overlying till and fine-grained stratified deposits). Areas classified as cranberry bogs, forested wetland, and nonforested wetlands overlying both till and sand and gravel were combined to form single HRUs (PERLNDs 17, 18, and 19). The residential HRUs and wetlands are described in greater detail below.

Forest overlying till and fine-grained stratified deposits (PERLND 9), which represents about 22 percent of the total area in the basin, is the dominant HRU in the basin followed by forest overlying sand and gravel (PERLND 1), which represents about 15 percent of the total area (table 1-4). Forests compose up to 59 percent of subbasin area in the relatively undeveloped parts of the basin and as little as about 1 percent subbasin area in urban areas. Forests compose 27 percent of the drainage area to the Matfield River station (station no. 01106500), 33 percent of the drainage area to the Poor Meadow Brook station (station no. 01106900), and 53 percent of the drainage area to the Segreganset River station (station no. 01109070). Open, nonresidential land use composes about 6.5 percent of the basin. Agricultural land use composes about 5.5 percent of the basin, and commercialindustrial-transportation land use composes about 1.5 percent of the basin (table 1-4).

Residential areas were represented initially by two HRUs (medium- to low-density residential and high-density residential) for each type of surficial geology. The medium- to low-density residential categories were subdivided further by use of 1990 census block data (Massachusetts Office of Geographic Information, 2008d) to delineate areas served by onsite septic systems so that septic effluent could be better represented in a water-quality model. Census data were used because public-utility maps were not readily available across the basin, and 1990 census data were used rather than 2000 data because questions about water and sewer infrastructure were not asked in 2000 .

To estimate residential areas served by onsite septic systems in the HSPF model, the following procedure was used: (1) the number of households in each full and partial block with a private well and septic system (private water/ private sewer) and a public-water supply and septic system (public water/private sewer) was determined; (2) the amount of medium- and low-density residential area in each block was determined (it was assumed that high-density residential areas were served by public utilities); (3) the number of households in each block was apportioned to a medium- or low-density residential area, and then converted to an area by multiplying by 0.375 acres for medium-density residential areas and by 0.75 acres for low-density residential areas; (4) effective impervious area was subtracted from each area $(5$ percent for medium-density and 2 percent for low-density residential areas), and the remaining pervious areas were added together; (5) census blocks were mapped onto model subbasins, and the amount of private water/private sewer and public water/private sewer residential area in each subbasin was calculated; (6) the two new residential areas then were apportioned to sand and gravel or till and fine-grained stratified deposits based on the percentages of these surficial-geology types in the subbasin; and (7) the new areas were subtracted from the original medium- to low-density residential HRU to form two new HRUs for each surficial geology type (table 1-4).

This approach involved many assumptions but appeared to provide a reasonable approximation of the spatial distribution and areal extent of residential areas served by septic systems in the basin. Approximately 64,500 households out of an estimated 140,000 households in the basin had septic systems in 1990, of which 13,500 had private wells and septic systems and the remaining 51,000 had public-water supplies and septic systems. The total residential area served by septic systems was about 32,700 acres, of which 8,300 acres was for households with private wells and septic systems and the remaining 24,500 acres was for households with publicwater supplies and septic systems. The average lot size was about 0.5 acre. As shown in table A4, the total medium- to low-density residential area served by septic systems (HRUs $4,5,12$, and 13) was about 51 percent of total medium- to low-density residential area of 63,600 acres in the basin. The remaining medium- to low-density (HRUs 3 and 11) and high-density (HRUs 6 and 14) areas in the basin are assumed to be largely served by public-water and public-sewer systems (the combination of private wells and public-sewer systems is assumed to be uncommon).

Residential areas on public-water and septic systems (PERLNDs 4 and 12) result in a net inflow (or import) of water to the local area. The water imported to these residential areas is not linked to any specific source or water-treatment facility, so the location of the public water-supply sources is inconsequential to these transfers. Simulation of water imports in the Taunton River Basin HSPF model is described below in the Water Use section. Residential areas with the other two water supply and disposal combinations, private wells and septic systems and public-water and public-sewer systems, do not result in net transfers of water to or from the local area. In areas where water is self-supplied and wastewater is self-disposed, water is cycled (withdrawn and returned) locally. Similarly, in areas where residences and businesses are connected 
to both public-water and public-sewer systems, there is no net import or export of water to or from the local area. It should be noted that this water use is accounted for in the model by incorporating the major municipal withdrawals and wastewater-return flows that serve these areas into the model, if they occur within the basin. The small amount of consumptive water loss (water lost to the atmosphere) associated with selfsupplied systems was not simulated. The consumptive water loss associated with publicly supplied systems was implicitly accounted for as the difference between reported municipal withdrawal and wastewater-return flow rates.

\section{Stream Reaches (RCHRES)}

The Taunton River and its main tributaries were segmented into 63 reaches (fig. 1-2; table 1-6). Segmentation was based on hydrologic characteristics, the availability of streamflow data, locations of impaired 303d-listed reaches, and to a lesser extent, the size of the drainage area and waterand land-use characteristics. Nine reaches were established along the main stem of the Taunton River, and 54 reaches were established on the tributaries. Most tributaries were subdivided into multiple reaches. For example, the Matfield River and its main tributaries were represented by 12 reaches, the Wading River, Nemasket River, and Threemile River by 4 reaches each, and the Segreganset River and Winnetuxet River by 2 reaches each. Twenty reaches were created in the impaired-reach model area (table 1-6). To the extent possible, the lengths and downgradient nodes of the model reaches correspond to the impaired reaches defined by MA DEP (table 1). The total area of HRUs and open water in each subbasin was determined by intersecting the HRU data layer with the subbasin delineation data layer.

\section{Hydraulic Characteristics (FTABLEs)}

Stage-storage-discharge characteristics (FTABLEs) were developed for the outflow gate used to route water from each of the 63 reaches. These characteristics are usually defined by the hydraulic properties at the downstream end of the reach, but the discharge-volume relation is a function of the properties of the entire reach. FTABLEs were developed to represent lake or reservoir (hereafter referred to as reservoir FTABLEs) depth-storage-discharge relations in the five reaches dominated by large surface-water bodies (table 1-6). FTABLEs representing stream reaches were developed for the remaining 58 reaches. Of the 63 reaches in the basin, 20 reaches are in the calibrated, impaired-reach areas (fig. 1-1; table 1-6). The 43 reaches outside the impaired-reach model area are uncalibrated for streamflow but FTABLEs were constructed for possible future expansion of the calibrated model.

For stream reaches in which channel-geometry information was available, the channel-geometry analysis program (CGAP) by Regan and Schaffranek (1985) was used to define the relations among depth, surface area, and volume. A supplemental program, GENFTBL, reads the channel-geometry output from CGAP to calculate the stage-storage-discharge relation by solving Manning's equation for open-channel flow. CGAP requires cross-sectional channel geometry, which was obtained from discharge-measurement notes made at streamgages. Cross-sectional information from streamflow measurements was available for seven reaches in the basin. The cross section measured at a gaging station was assumed to represent the entire reach. For the majority of the reaches in the basin, in which channel-geometry measurements were not available, the program XSECT (AquaTerra Consultants, written commun., 1998) was used to develop FTABLEs. XSECT differs from CGAP in that the channel cross section is assumed to be trapezoidal. The equation for a trapezoidal channel with a 1:1 side slope was used to determine channel dimensions (Chow, 1959). Relations between drainage area, bankfull width, and bankfull depth (Leopold, 1994) were used to approximate the size of the channel for each reach. XSECT was used to develop FTABLEs for 51 reaches in the basin.

Both GENFTBL and XSECT require Manning's roughness coefficients to calculate flow velocity; these coefficients were estimated from guidelines by Coon (1998) and Arcement and Schneider (1989). Stream lengths and slopes were determined from geospatial data, such as topographic and hydrographic data, describing stream centerlines and altitudes. For reaches with streamgages, calculated stage-discharge relations were compared with measured discharges, and the stagestorage-discharge relations in the FTABLE were adjusted, if necessary, to improve the representation of the hydraulic characteristics of the reach. For reaches with no channelgeometry information, the calculated discharge at bankfull in the FTABLE was compared to bankfull discharge compared to drainage-area relations (Leopold, 1994), and FTABLEs were adjusted if necessary. Mean annual discharges calculated as 1.8 cubic feet per second $\left(\mathrm{ft}^{3} / \mathrm{s}\right)$ times the drainage area (Leopold, 1994) also were compared to the FTABLE discharges calculated at depths equal to 0.3 times bankfull depths (Leopold, 1994) as a rough check on the accuracy of the stagestorage-discharge relations in the FTABLEs.

The majority of the approximately 60 dams in the Taunton River Basin are relatively small run-of-river structures that do not impound large volumes of water. These impoundments were not explicitly simulated in the HSPF model. At five locations in the basin, however, reservoirs (Norton Reservoir, reach 9; Lake Sabbatia, reach 17; and Monponsett Lake, reach 33) or naturally occurring lakes (Long Pond, reach 40; and Assawompsett Pond, reach 41) were dominant surface-water features and were simulated as reservoirs in the HSPF model (table 1-6).

Reservoir-capacity or bathymetry data were not readily available for these reservoirs, so stage-storage relations were estimated by use of surface areas calculated from 1:25,000-scale hydrography and maximum water depths from MassWildlife pond bathymetry maps (Massachusetts Department of Fish and Game, 2008) or reported depths behind dams (Federal Emergency Management Agency, 
1994). Most of the storage volume of a reservoir does not play a role in precipitation-runoff relations under normal climatic conditions; however, to allow for water-quality simulations, full storage volumes of the reservoirs were included in the FTABLEs. On the basis of visual inspection and other documentation, reservoir outlet structures were simulated as spillways. The stage-storage-discharge relations were developed to represent the observed outlet structure as realistically as possible. Data on the size, shape, and altitude of the outlet structures were used where available; otherwise, approximations based on visual inspection were made to develop the FTABLEs. For Lake Sabbatia, Norton Reservoir, and Assawompsett Pond, flow was calculated with a sharpcrested weir-flow equation (Chow, 1959). For Long Pond and Monponsett Lake, stream channels controlled output and therefore XSECT was used to compute stage-discharge relations as described above. Reservoir management activities, such as adding or removing flashboards or changing gate settings, were not simulated in the HSPF model.

\section{Wetlands}

Wetlands, which account for 18 percent of the Taunton River Basin, represent an important storage component of the watershed. To account for this storage, wetlands were simulated as "virtual" in 26 reaches in the basin (table 1-6). Virtual reaches were set up for most of the larger subbasins in which wetlands composed 20 percent or more of the subbasin area, and for smaller subbasins in the impairedreach model area. For the remaining subbasins, forested and nonforested wetlands were simulated as PERLNDs 18 and 19, respectively. Representing wetlands as virtual reaches (areas that exchange water with the atmosphere through precipitation and evapotranspiration and receive inflows from adjacent PERLNDs and IMPLNDs) rather than as PERLNDs, where evapotranspiration losses are limited to precipitation falling directly on the wetlands, was found to be an effective means of simulating wetlands in the Ipswich and Blackstone River Basins (Zarriello and Ries, 2000; Barbaro and Zarriello, 2006). Evapotranspiration in wetlands is typically larger than the direct precipitation on the wetlands because additional water is available from surface and subsurface flows from surrounding uplands. When wetlands are simulated as PERLNDs, evapotranspiration loss is limited to the difference between precipitation falling directly on the wetland and runoff from the wetland, which can result in oversimulation of observed low flows. Because cranberry bogs typically are not flooded during the summer, they were simulated as PERLNDs rather than virtual reaches. All PERLNDS and IMPLNDS were assumed to drain into the virtual reaches before draining into the stream and reservoir reaches.

Virtual reaches represent the combined storage of all forested and nonforested wetlands in a subbasin. Combined storage of open water (stream networks, reservoirs, and lakes) in a subbasin was represented in a separate FTABLE to retain the ability to simulate water quality in wetlands and open water as separate systems. The total surface area of wetlands was represented in the virtual reach. The total surface area of open water was represented in the regular stream or reservoir reach. This approach resulted in an accurate total surface area of open water and wetlands for each subbasin. However, surface areas in virtual-reach FTABLEs were decreased at the lowest flows (below approximately $5.0 \mathrm{ft}^{3} / \mathrm{s}$ ) to account for decreases in free-water surface in wetlands during dry periods and prevent excessive evapotranspiration loss during these periods.

The basin storage-discharge characteristics were similar for all of the virtual reaches in the basin. Generally, discharge in the virtual reaches is low and increases relatively little as storage increases in comparison to stream reaches. Storage volumes were scaled to surface area, and discharges were roughly scaled to subbasin area. Virtual-reach FTABLEs at streamgages were adjusted empirically during flow calibration. These changes typically involved changing the functional relation between storage and discharge (that is, the rate of change of discharge for a given change in storage) for specific flow ranges to improve the model fit. The altered storage-discharge relation at the Segreganset at North Dighton station (the one station in the impaired-reach model area with measured streamflow for the entire calibration period) then was applied to all of the other virtual reaches in the basin. Simulating wetlands as reaches yielded good agreement between simulated and observed hydrographs. However, the storage-discharge characteristics and interactions between groundwater and surface water are not well defined for virtual reaches. In addition, simulating wetlands as reaches with a variable area introduces a structural error in the model, because the drainage area that exchanges water with the atmosphere decreases during dry periods (Zarriello and Ries, 2000).

\section{Water Use}

Certain aspects of the water use in the basin were simplified for inclusion in the HSPF model. For example, in most cases, transfers of water across the basin boundary and between towns and water suppliers in the basin are not explicitly represented in the model. Rather, all major watersupply withdrawals from groundwater and surface-water sources that are distributed through public-water systems and the wastewater-return flows through municipal wastewatertreatment plants are represented in the model as individual withdrawal and return time series in the individual subbasins where they are located; the difference between total withdrawals and total return flows represents the net overall import or export of water for the basin. The model does not explicitly simulate leakage (unaccounted water) from public water-supply systems, which is estimated to be 10 to 15 percent of the water withdrawn for public water supply (Barlow and others, 2003); however, some of this water likely is accounted for in the HSPF model by the difference between reported municipal water-supply withdrawals and wastewater-return flows. Further simplifications include omission of (1) withdrawals from minor public suppliers (housing developments, apartment 


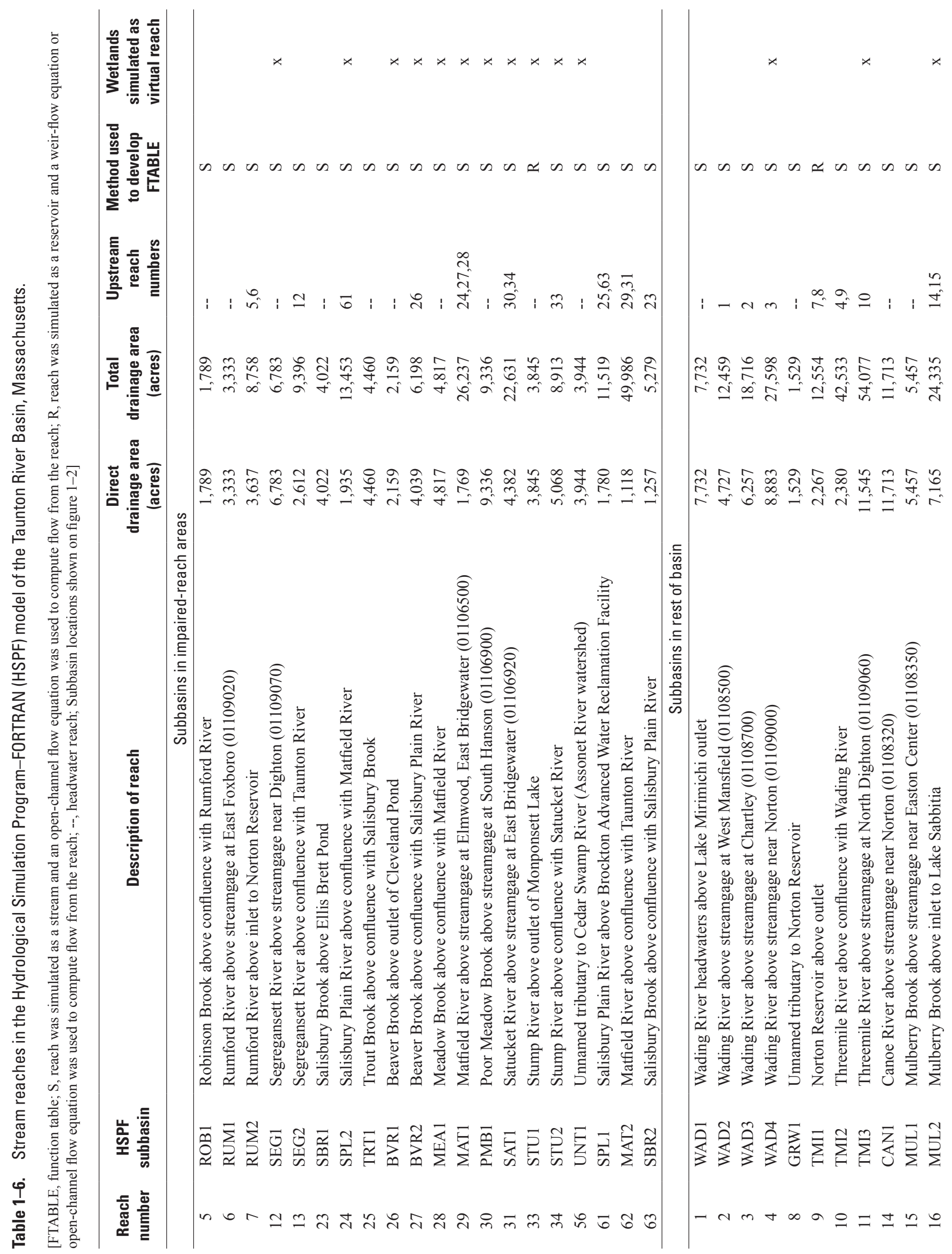




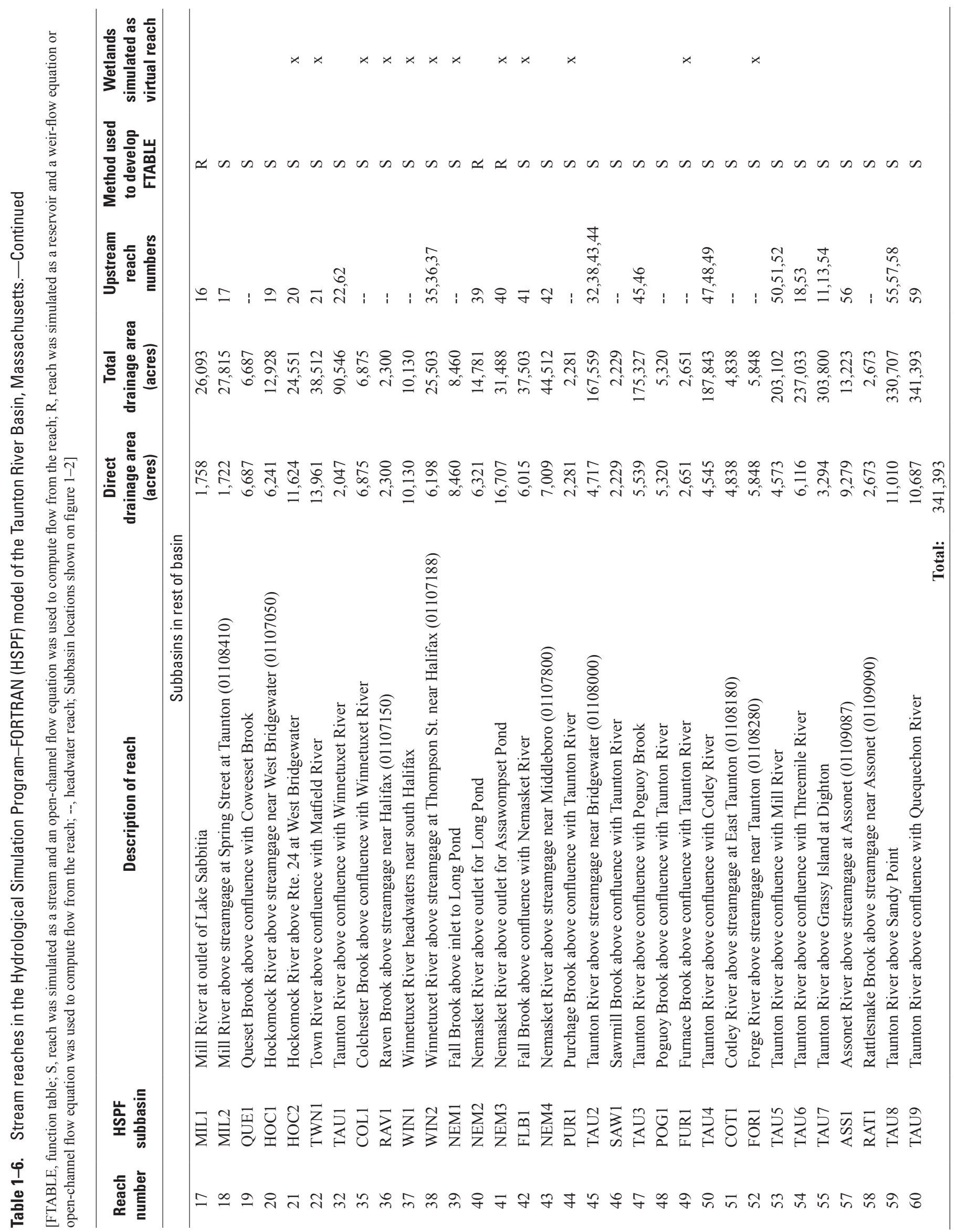


complexes, and nursing homes), (2) withdrawals from private wells that are returned locally to onsite septic systems, (3) wastewater-return flows for minor discharges from permitted facilities, and (4) wastewater-return flows from residential areas with private wells and septic systems. With the exception of golf-course and cranberry-bog irrigation, most of the agricultural water use was not simulated because withdrawals in the basin are expected to be minor (that is, less than about $0.001 \mathrm{Mgal} / \mathrm{d} / \mathrm{mi}^{2}$ based on agriculture water-use data for the Rhode Island part of the Blackstone River Basin (Barbaro and Zarriello, 2006)).

Thirteen of the 20 reaches in the impaired-reach model area contain municipal, commercial, or irrigation withdrawals, and 3 reaches contain municipal or commercial wastewater-return flows (fig. 1-1). Septic-effluent return flows for households served by public-water systems are associated with residential HRUs and are present throughout the impairedreach model area.

In HSPF, outflows from different exits in a reach must be satisfied in successive order. For example, the time-dependent volume-outflow demands for municipal and commercial withdrawals (exit 1) must be satisfied before water is routed downstream (exit 2). In reaches where there are only municipal and commercial withdrawals ( 9 of 20 reaches), the withdrawals are taken from the first exit and the remaining flow is routed downstream through the second exit. In reaches where there are only cranberry-bog irrigation withdrawals ( 2 of 20 reaches), the withdrawals are taken from the first exit and the remaining flow is routed downstream through the second exit. In reaches where there are both municipal and commercial withdrawals and cranberry-bog irrigation withdrawals ( 2 of 20 reaches), the withdrawals are taken from the first and second exits, respectively, and the remaining flow is routed downstream through the third exit. The first outflow exit is used to route water downstream in reaches where no withdrawals occur ( 7 of 20 reaches).

\section{Municipal, Commercial, and Irrigation Withdrawals}

Time series for each of the 39 municipal/commercial and golf-course irrigation withdrawals in the impaired-reach model area were grouped by reach. When a reach contained multiple withdrawals (table 1-1), they were summed to obtain a total streamflow-depletion rate (demand) for that reach. Time series for the period 1997-2006 are stored in DSNs 101 to 162 , corresponding to reaches 1 through 62 , respectively. Time series for cranberry-bog irrigation withdrawals were based on the total bog acreage in each subbasin with appreciable bog agriculture. Cranberry-bog irrigation time series were stored in DSNs 2316, 2333, 2341, and 2561 for reaches 31,33 , 34, and 56 , respectively.

The water-supply system for the city of Brockton is relatively complex, consisting of multiple surface-water and groundwater sources and including interbasin transfers of surface water (Massachusetts Department of Environmental Protection, Southeastern Region, personal commun., 2008). The city obtains water mainly from Silver Lake in the South Coastal Basin (about 94 percent of total). Supplemental sources in the Taunton River Basin include Avon Reservoir (also known as Brockton Reservoir) in reach 23 (about 6 percent of total), Hubbard Avenue well in reach 61 (not in HSPF model because well is inactive and only available as emergency backup supply), and Monponsett Lake in reach 33 (seasonal diversions to Silver Lake). For the period 19972006, annual transfers from Monponsett Lake to Silver Lake averaged about $6.4 \mathrm{Mgal} / \mathrm{d}$ (table 1-1), but daily diversion rates were as high as about $28 \mathrm{Mgal} / \mathrm{d}$ during October through May when diversions were taking place. The city of Brockton actively monitors and regulates the level of Monponsett Lake and wetlands at the downstream outlet of the lake. Flow over the outlet control structure for the lake also is regulated to maintain flow during the summer (Brian Creedon, City of Brockton, personal commun., 2008).

To represent the Brockton water supply system in the HSPF model, only the withdrawals from the basin itself were simulated: withdrawals from Avon Reservoir (DSN 2231) and diversions from Monponsett Lake (DSN 2332). Water exported into the basin from the South Coastal Basin was not simulated explicitly as an inflow time series, but much of this water was represented in the model as wastewater-return flows to the Brockton AWRF and septic systems in residential areas served by public water supplies.

\section{Municipal and Industrial Wastewater-Return Flows}

Wastewater is returned to the reach in which the outfall is located as an inflow time series. Wastewater-return flow time series for the period 1997-2006 are stored in DSNs 3241, 3291, and 3301 (table 1-2). Treated municipal wastewater returned to the Salibury Plain River (reach 24) from the Brockton AWRF originates from a variety of sources: domestic wastewater from residential and institutional sources, nondomestic wastewater from commercial and industrial sources, and groundwater and storm water from infiltration and inflow (I/I). There are no combined sewers (intentional connections between storm and sanitary sewers) in the Brockton publicsewer system. In the context of a sanitary-sewer system, infiltration refers to groundwater that enters the system through leaks in pipes, connections, and manhole walls, and inflow refers to stormwater that inadvertently enters the system through interconnections with roof and foundation drains, sump pumps, and manhole covers. An engineering study based on 1996-97 return-flow data indicated that infiltration represented 45 percent of the total flow to the plant during December through May when groundwater levels were high (Brockton Advanced Water Reclamation Facility, written commun., 2007). For the 1997-2006 calibration period, the average December through May return flow rate was $22.9 \mathrm{Mgal} / \mathrm{d}$. 
Thus, assuming the 1996-97 infiltration data applies to the entire calibration period, infiltration was $10.3 \mathrm{Mgal} / \mathrm{d}$ for these months. It was assumed that infiltration dropped to about $2 \mathrm{Mgal} / \mathrm{d}$ during dry months, resulting in an annual average infiltration rate of $6 \mathrm{Mgal} / \mathrm{d}$, or about 30 percent of the annual average total return-flow rate of $20.2 \mathrm{Mgal} / \mathrm{d}$. Stormwater inflow was estimated to be $38.6 \mathrm{Mgal} / \mathrm{d}$ for a 1.7 -in. rainfall (Brockton Advanced Water Reclamation Facility, written commun., 2007). Assuming a linear response to rainfall, annual average stormwater inflow was estimated to be about 3.5 Mgal/d for the period 1997-2006, or 17 percent of the annual average total return-flow rate. Overall, I/I was estimated to be about $9.5 \mathrm{Mgal} / \mathrm{d}$ (47 percent of total wastewaterreturn flow), of which $6 \mathrm{Mgal} / \mathrm{d}$ was from groundwater infiltration and $3.5 \mathrm{Mgal} / \mathrm{d}$ was from stormwater inflow.

Precipitation on the sewered areas in the basin is the source of the I/I in the wastewater-return flow. Because wastewater returns are added to reaches as external sources of water in HSPF, I/I contributions to wastewater-return flows represent excess water (that is, water added to the model as both precipitation and wastewater-return flow). HSPF is not designed to simulate the movement of water in sewer systems in urban areas; however, the model has the flexibility to account for the effects of $\mathrm{I} / \mathrm{I}$ in a simplified manner. To remove the excess water returned to the basin at the Brockton AWRF outfall, portions of HSPF-simulated flow components were routed out of the basin, rather than to stream reaches, in the subbasins encompassing the Brockton sewer system service area (subbasins SPL2, TRT1, BVR2, MEA1, SPL1, and SBR2). These changes are made in the MASS LINK block of the HSPF control file. To decrease flow at the Matfield River at Elmwood streamgage to account for I/I, surface-water discharge (SURO) was reduced by 55 percent, and active groundwater discharge (AGWO) was reduced by 38 percent to stream reaches in the subbasins listed above. Interflow discharge (IFWO) was not altered. Routing these percentages of the flow components out of the watershed reduced the simulated 1997-2006 average flow at this location from 126 to $110 \mathrm{ft}^{3} / \mathrm{s}(10.3 \mathrm{Mgal} / \mathrm{d})$ for the calibrated model. The average measured streamflow for this period was $106 \mathrm{ft}^{3} / \mathrm{s}$. A 55-percent reduction in SURO corresponded to about 4.3 Mgal/d less flow and a 38-percent reduction in AGWO corresponded to about $6 \mathrm{Mgal} / \mathrm{d}$ less flow, roughly corresponding to the I/I calculations. Although routing flow components out of the basin provides only a rough approximation of the spatial and temporal distribution of I/I flows in the Brockton sewer system, accounting for these flows is more realistic than leaving excess water in the basin, which could lead to skewed parameter values in the calibrated model.

\section{Septic-Effluent Returns in Residential Areas with Public-Water Supplies}

The quantity of septic effluent imported to medium- to low-density residential areas served by public-water systems was calculated by multiplying the average population density ( 2.8 persons per household on 0.48 -acre lots) by the average rate of water use of $67 \mathrm{gal} / \mathrm{d}$ per person (Korzendorfer and Horn, 1995), resulting in an import rate of $309 \mathrm{gal} / \mathrm{d} / \mathrm{acre}$. This import rate was converted to $0.0005992 \mathrm{in} / \mathrm{hr} / \mathrm{acre}$ and added to the applicable HRUs (PERLNDs 4, and 12) as inflow to lower-zone storage (LZLI). Applying water to lower-zone storage is appropriate because septic leach fields typically are installed in this part of the soil horizon. In HSPF, water in the lower soil zone is not available to runoff or discharge as interflow or base flow. Rather, this storage zone holds water that is removed to the atmosphere through evapotranspiration. Adding septic effluent to lower-zone storage decreases the storage available in this zone for infiltrating precipitation. Consequently, more infiltrated precipitation reaches active groundwater storage, which is available to discharge as base flow, in areas receiving septic effluent relative to similar areas not receiving effluent. The estimated import rate from residential areas with public-water supplies and septic systems is $5.2 \mathrm{in} / \mathrm{yr}$, which represents about 12 percent of the average annual precipitation of $42 \mathrm{in} / \mathrm{yr}$.

Pervious medium- to low-density residential areas on public-water and septic systems compose about 7 percent (24,370 acres) of the basin area. Pervious medium- to lowdensity residential areas on private wells and septic systems compose an additional 2.4 percent $(8,225$ acres) of the basin area. Thus, the widely distributed septic effluent affects an appreciable percentage of the basin area, and may, along with residential lawns, constitute an important nonpoint source of nitrogen in the watershed.

\section{Flow Calibration}

The flow model was calibrated for the period January 1, 1997, to December 31, 2006, using an hourly time step and climatic data from T.F. Green Airport in Warwick, R.I., and Taunton Municipal Airport in Taunton, Mass. (see Climate section of the appendix for a description of climate variables). The average precipitation at T.F. Green Airport for the calibration period was slightly less than the long-term average precipitation (1960-2006). Precipitation at this station averaged $46 \mathrm{in} / \mathrm{yr}$ for the calibration period. Precipitation at the Taunton Municipal Airport, which is more representative of local conditions in the basin, averaged $49 \mathrm{in} / \mathrm{yr}$ for the period 1998-2006. Of these years, 2004 was the wettest and 2000 was the driest. The model was run from 1996 onward to allow the initial values for the less-dynamic soil and groundwater storages (upper-zone storage [UZS], lower-zone storage [LZS], active groundwater storage [AGWS], and the initial index to groundwater slope [GWVS]) to approach dynamic equilibrium, but 1996 was not used to determine the goodnessof-fit between simulated and observed flows.

Withdrawal and wastewater-return flow data are needed to estimate model parameters. The inclusion of the major 
stresses in the basin ensures that the net effect of the stresses on simulated hydrographs is represented, and the calibrated values of the model parameters better represent the hydrologic response of the basin to precipitation (Zarriello and Ries, 2000). Simulations for model verification were not conducted because establishing a verification period required shortening the length of the calibration period and reducing the reliability of parameter calibration. Consequently, all 10 years of wateruse and climatic data were used for parameter calibration. The model fit to observed flows for this period provides the best verification of the calibrated model parameters over the widest range of climatic conditions.

The model was calibrated in accordance with guidelines by Donigian and others (1984) and Lumb and others (1994). Calibration entailed adjusting the parameter values to fit the model output to total and seasonal water budgets, and then adjusting values to improve the model fit for daily flows while maintaining the total and seasonal water budgets. Generally, annual and seasonal flows are affected most by the parameters lower-zone nominal storage parameter (LZSN), lower-zone evapotranspiration parameter (LZETP), upper-zone nominal storage parameter (UZSN), groundwater recession parameter that determines the degree of nonlinearity of the recession rate (KVARY), and active groundwater recession constant (AGWRC). Stormflows are affected most by infiltration parameter (INFILT), coefficient that determines the amount of water that enters the ground from surface storage and becomes interflow (INTFW) and interflow recession constant (IRC). The model was calibrated by first adjusting parameter values as a group for PERLNDs overlying sand and gravel and PERLNDs overlying till and fine-grained stratified deposits. Once reasonable simulation results were obtained, judgments based on hydrologic experience were used to make further adjustments to parameter values for individual PERLNDs representing different land-use types in each of these geologic groups. The snow accumulation and melt routines were included primarily to adjust precipitation data to compensate for inefficiencies in precipitation measurements during cold periods when precipitation was in the form of snow. SNOW module parameters were obtained mostly from other HSPF studies (U.S. Environmental Protection Agency, 2000).

Values for some parameters, such as the slopes and altitudes, were determined from spatial data. However, most parameters could not be measured directly and initially were assigned values similar to those used for comparable HRUs in other HSPF models developed by the USGS for basins in eastern Massachusetts or values developed from other applications of HSPF across North America (U.S. Environmental Protection Agency, 2000). The iterative process described above then was used to adjust these values to minimize the difference between simulated and observed flows, displayed as hydrographs, scatterplots, and flow-duration curves, and reduce the errors in the model-fit statistics. The PERLND parameters that affect the rate of groundwater and interflow recession (AGWRC, KVARY, IRC, and INTFW) and the amount of discharge as base flow and interflow (INFILT,
LZSN, UZSN, and LZETP) were adjusted most extensively to calibrate the model. Simulation results were insensitive to most of the remaining parameters; consequently, values for these parameters were not adjusted from initial values during the calibration.

Streamflow data from the three streamgages in the impaired-reach model area (fig. 1-1) were used to calibrate the flow model; however, the long-term station with measured streamflow (Segreganset River near Dighton) provided the primary data for determining calibrated parameter values. Agreement between simulated and observed flows was taken into consideration at the other stations, but, in general, standards for model performance were relaxed slightly at these stations because observed flows were estimated by use of record-extension techniques, and therefore likely contain more error than measured flows. All streamflow measurements, whether measured directly during the calibration period or estimated by use of record-extension techniques, are referred to as "observed" streamflow in the following discussion of model performance.

The quality of the model fit was examined by mathematical summary statistics provided by utilities in the software programs GenScn and HSPEXP. The time-series-compare utility in GenScn provides fit statistics computed from daily and monthly discharge values. The statistics reported here include the simulated and observed mean-flow rates, the mean error, the percent mean error, the root mean square error (RMSE), the Nash-Sutcliffe coefficient, and the coefficient of determination $\left(r^{2}\right)$ for daily flows during the calibration period (table 1-7). The mean error is defined as the absolute difference between the mean observed and mean simulated flow rates. The percent mean error is defined as the ratio of the mean error to the mean observed flow rate expressed as a percentage. The RMSE and mean error express the difference between the observed and simulated streamflow in original (cubic feet per second) units. The Nash-Sutcliffe coefficient provides a measure of the amount of the variance in the observed values explained by the simulated values.

Percent mean errors ranged from -6.6 percent at the Segreganset River station to 0.2 percent at the Matfield River station (table 1-7). Love and Donigian (2002) indicate that HSPF model fits for streamflow are considered very good when errors are less than 10 percent, good when errors are between 10 and 15 percent, and fair when errors are between 15 and 25 percent. The Nash-Sutcliffe coefficient, which can range from minus infinity to 1.0 , ranged from 0.57 at the Matfield River station to 0.73 at the Segreganset River and Poor Meadow Brook stations. Overall, the statistics shown in table 1-7 indicate that the agreement between simulated and observed values was poorest at the Poor Meadow Brook and Matfield River stations, and best at the Segreganset River station.

The HSPEXP program provides model-fit information in terms of the error between various measures of observed and simulated values. These measures include error during the calibration period in the total and seasonal runoff volumes, 
Table 1-7. Hydrological Simulation Program-FORTRAN (HSPF) model-fit statistics for observed and simulated daily mean streamflow for the period 1997-2006, Taunton River Basin, Massachusetts.

[ft $\mathrm{ft}^{3} / \mathrm{s}$, cubic feet per second; --, not available; NS, Nash-Sutcliffe coefficient; GenScn and HSPEXP are HSPF utility programs]

\begin{tabular}{|c|c|c|c|c|}
\hline Statistic & $\begin{array}{c}\text { Acceptance } \\
\text { criteria } \\
\text { (percent) }\end{array}$ & $\begin{array}{c}\text { Segreganset } \\
\text { River near } \\
\text { Dighton } \\
(01109070)\end{array}$ & $\begin{array}{c}\text { Matfield River at } \\
\text { Elmwood, East } \\
\text { Bridgewater } \\
(01106500)\end{array}$ & $\begin{array}{c}\text { Poor Meadow } \\
\text { Brook at South } \\
\text { Hanson } \\
(01106900)\end{array}$ \\
\hline \multicolumn{5}{|c|}{ GenScn } \\
\hline Mean observed flow rate $\left(\mathrm{ft}^{3} / \mathrm{s}\right)$ & -- & 24.2 & 106.7 & 32.0 \\
\hline Mean simulated flow rate $\left(\mathrm{ft}^{3} / \mathrm{s}\right)$ & -- & 22.6 & 106.9 & 33.1 \\
\hline Mean error $\left(\mathrm{ft}^{3} / \mathrm{s}\right)$ & -- & -1.6 & 0.2 & 1.1 \\
\hline Percent mean error & -- & -6.6 & 0.2 & 3.6 \\
\hline Root mean square error $\left(\mathrm{ft}^{3} / \mathrm{s}\right)$ & -- & 18.8 & 84.0 & 21.7 \\
\hline Correlation coefficient & -- & 0.89 & 0.79 & 0.86 \\
\hline Coefficient of determination & -- & 0.80 & 0.63 & 0.73 \\
\hline Model fit efficiency (NS) & -- & 0.73 & 0.57 & 0.73 \\
\hline \multicolumn{5}{|c|}{ HSPEXP } \\
\hline Total flow volume & 10 & -6.6 & 0.2 & 3.6 \\
\hline Low-flow recession & 0.03 & 0.01 & 0 & -0.01 \\
\hline Lowest 50 -percent of flows & 10 & 10.2 & 3.1 & -3.6 \\
\hline Highest 10-percent of flows & 15 & -8.0 & 1.4 & 11.3 \\
\hline Storm peaks & 15 & 17.7 & 67.9 & 47.2 \\
\hline Seasonal volume & 10 & 6.0 & 20.0 & 15.6 \\
\hline Summer storm volume & 15 & -4.3 & -11.4 & -12.5 \\
\hline
\end{tabular}

flows above the 10th percentile (high flows) and below the 50th percentile (low flows), and the base-flow recession constant, which is the difference in the ratio of the current day's discharge to the previous day's discharge for simulated and observed flows. Errors also are computed for storm-runoff volumes and peak discharges for selected summer storms. These statistics were designed to work with the "expert" advice feature of HSPEXP. In general, errors in the total runoff volumes, low-flow recession constant, high and low flows, and summer storm volumes are within the criteria for acceptable model performance defined by Donigian and others (1984), whereas errors in the storm peaks and seasonal volumes are outside these criteria. Visual inspection of the hydrographs, flowduration curves, and scatterplots of simulated and observed streamflows at varying time scales provide additional information to evaluate model performance.

Overall, the statistics indicate that simulated flows agree well with observed flows at the three stations in the impairedreach model area. However, errors in observed streamflow may be substantial at the stations where streamflow was estimated by correlation with surrounding index stations. Also, measurement error and flow regulation may result in differences between the measured streamflow record at the
Segreganset station and the natural watershed response. Therefore, model-fit statistics may reflect the quality of the observed data as well as model performance, particularly at the stations with estimated data. Unaccounted for water use and precipitation variability can also affect the agreement between observed and simulated flows.

\section{Annual Mean Streamflow}

Observed and simulated annual mean streamflows for 1997-2006 are shown in figure 1-4. Observed annual mean flow ranged from about $160 \mathrm{ft}^{3} / \mathrm{s}$ (Matfield River station, 1998) to $17 \mathrm{ft}^{3} / \mathrm{s}$ (Segreganset River station, 1997). Overall, observed and simulated annual mean flows were in good agreement at the three flow-calibration stations. For the calibration period, annual mean streamflow was undersimulated by 6.6 percent at the Segreganset River station and oversimulated by 0.2 and 3.6 percent at the Matfield River and Poor Meadow Brook stations, respectively. The maximum single-year difference was an oversimulation of 28 percent at the Segreganset River station for 1999. The minimum single-year difference was an undersimulation of 1 percent at the Segreganset station for 

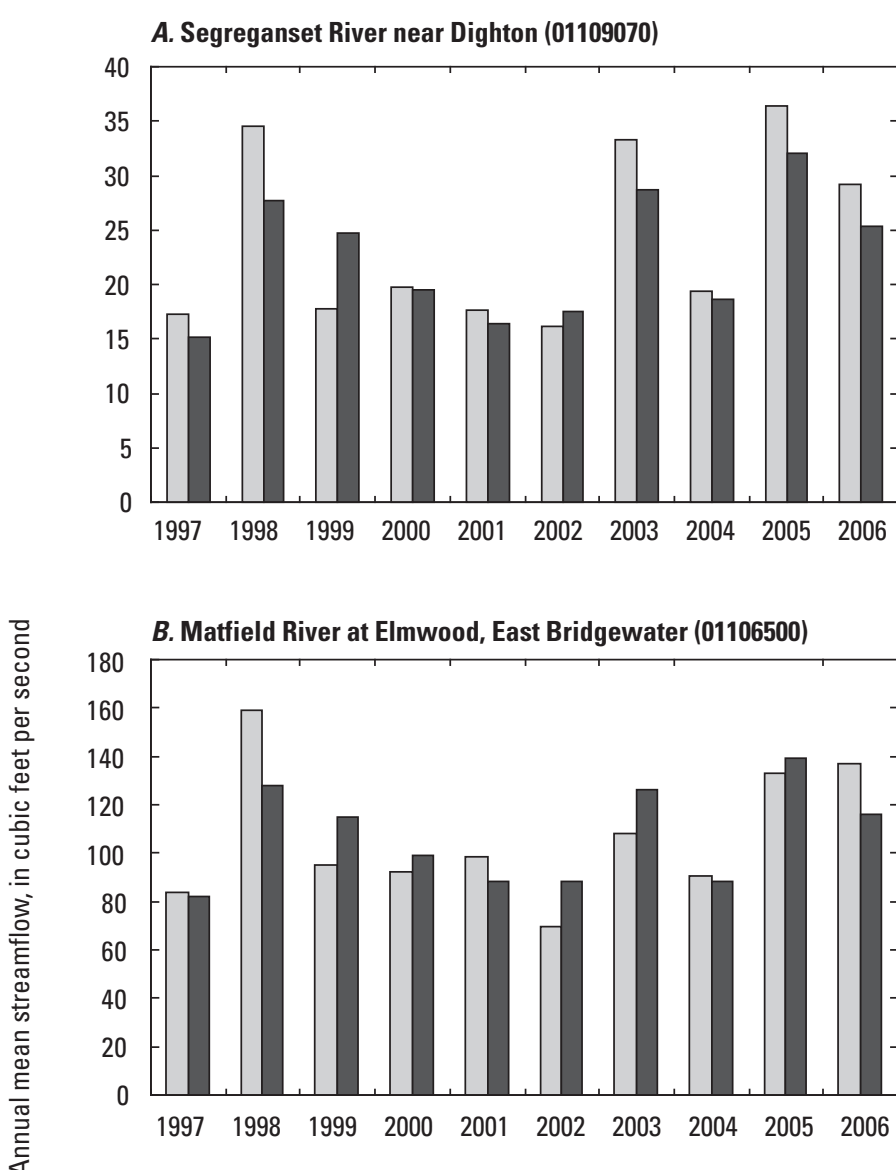

C. Poor Meadiow Brook at South Hanson (01106900)

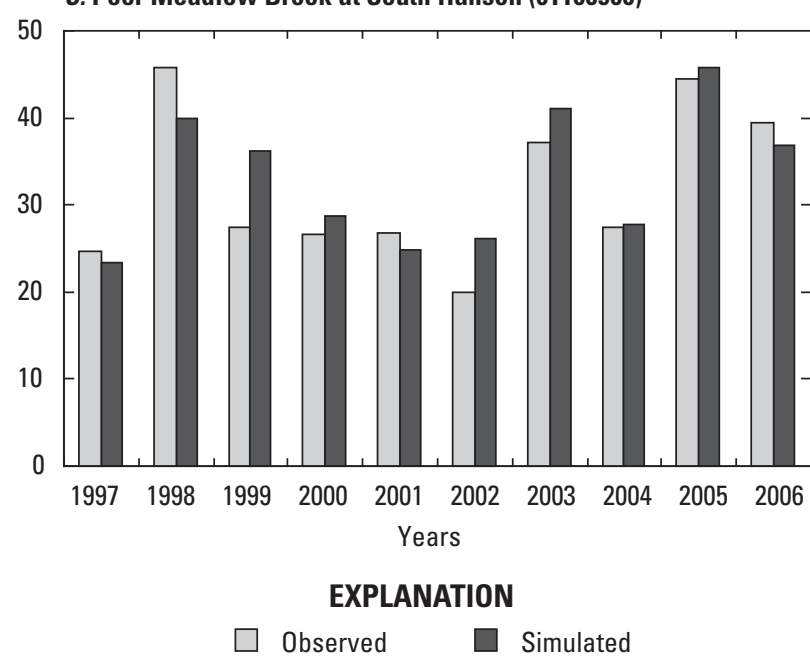

Figure 1-4. Relation between observed and simulated annual mean streamflow at calibration sites $A$, Segreganset River near Dighton (01109070); B, Matfield River at Elmwood, East Bridgewater (01106500); and C, Poor Meadow Brook at South Hanson (01106900).
2000. For 6 of 10 years in the calibration period, flows were slightly oversimulated or undersimulated at all three stations, perhaps reflecting minor differences between the climatic data used for the simulation and the actual conditions in the basin.

\section{Daily Mean Streamflow}

Hydrographs of observed and simulated daily mean streamflow indicate that the model performed well over a range of flows of about three orders of magnitude at the three streamgages used for calibration (fig. 1-5). Low flows ranged from about $0.1 \mathrm{ft}^{3} / \mathrm{s}$ (Segreganset River station) to about $30 \mathrm{ft}^{3} / \mathrm{s}$ (Matfield River station). Low flows at the Matfield River station are substantially augmented by wastewaterreturn flows from Brockton AWRF. High flows ranged from about $400 \mathrm{ft}^{3} / \mathrm{s}$ (Segreganset River and Poor Meadow Brook stations) to about 2,000 $\mathrm{ft}^{3} / \mathrm{s}$ (Matfield River station).

Scatterplots generally show good agreement between observed and simulated daily mean streamflow over the observed range of flow (fig. 1-6). Correlation coefficients ranged from 0.79 (Matfield River station) to 0.89 (Segreganset River station). At the Segreganset River station, there is considerable scatter for observed flows below about $1 \mathrm{ft}^{3} / \mathrm{s}$ (fig. 1-6). A possible explanation for the scatter is differences between the timing of actual and simulated daily withdrawals from the subbasin. Low flows at this location are affected by withdrawals, and flows frequently fall below $0.1 \mathrm{ft}^{3} / \mathrm{s}$, which is considered to represent no-flow conditions.

Flow-duration curves show the percentage of time a specified streamflow is equaled or exceeded (fig. 1-7). Overall, the flow-duration curves of simulated daily mean streamflow closely match observed streamflow (fig. 1-7). The largest discrepancies are at the extreme high and low flows. For extreme low flows (discharges that are equaled or exceeded about 98 percent the time), the model undersimulated streamflow the most at the Poor Meadow Brook station. This discrepancy may result partially from errors associated with the computed streamflow record at this station. At extreme high flows (discharges that are equaled or exceeded only about 0.2 percent of the time), the model undersimulated flow at the Segreganset River and Matifeld River stations, and oversimulated flow at the Poor Meadow Brook station.

The Nash-Sutcliffe coefficient indicated that the model explained 57 percent (Matfield station) to 73 percent (Segreganset and Poor Meadow Brook stations) of the variation in the observed daily mean streamflow at these stations (table 1-7). The range in the magnitude of model errors and visual model fits is the result of attempting to achieve a reasonable calibration across the basin; improvements in model error at a given location often worsened the model performance at other locations. As discussed previously, the primary calibration point was the Segreganset River near Dighton station because measured data were available for the calibration period. 


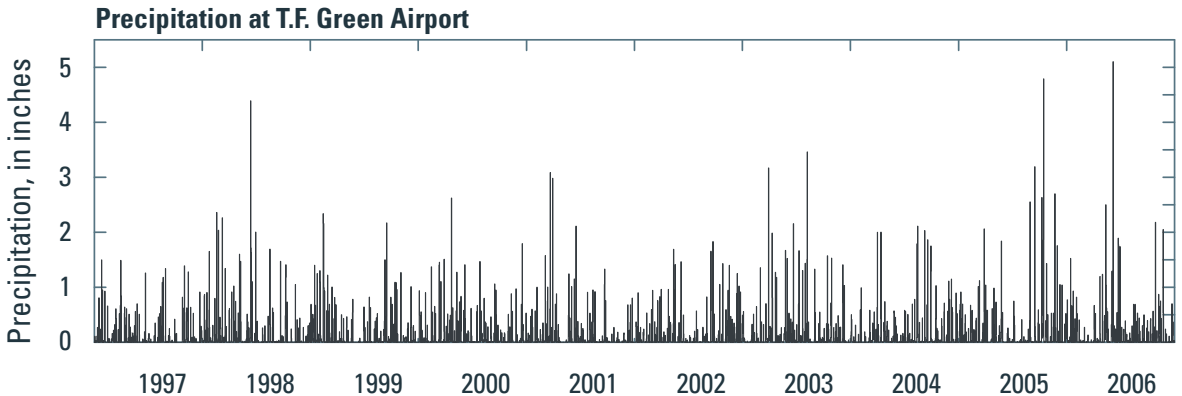

A. Segreganset River near Dighton (01109070)
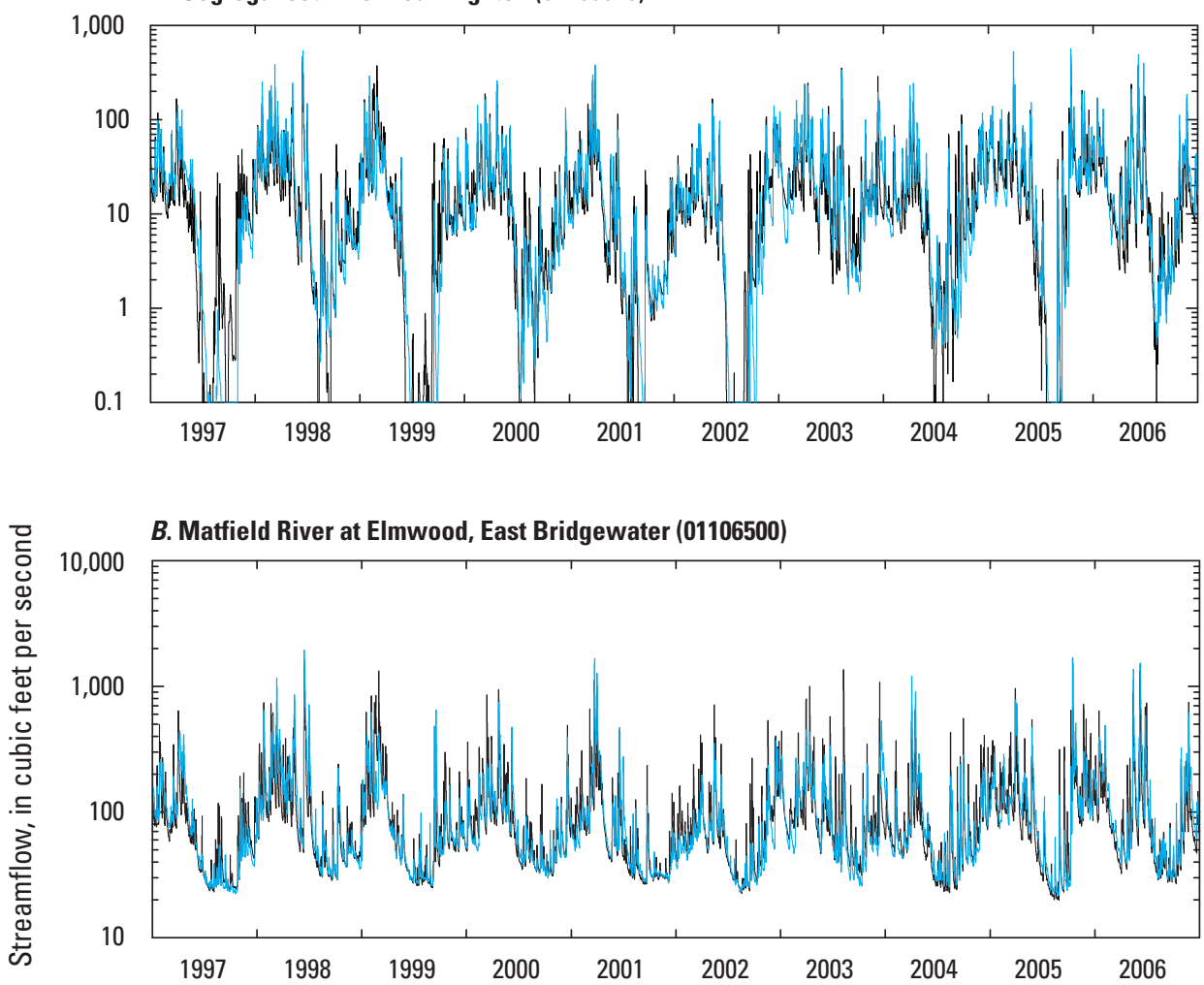

C. Poor Meadow Brook at South Hanson (01106900)

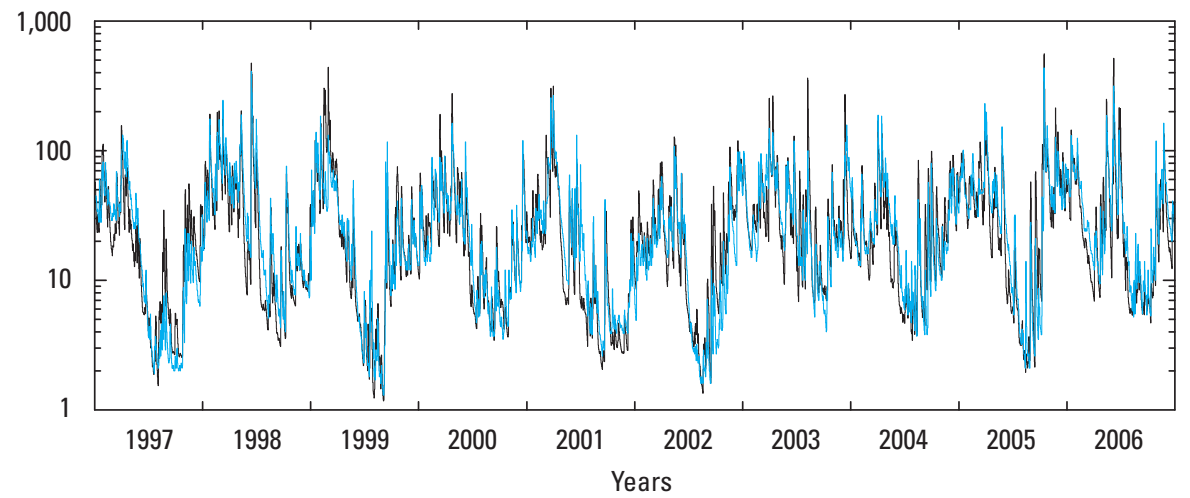

EXPLANATION
Figure 1-5. Daily precipitation at T.F. Green Regional Airport, Warwick, Rhode Island (January 1, 1997-November 4, 1997) and Taunton Municipal Airport, Taunton, Massachusetts (November 5 , 1997-December 31, 2006) and observed and simulated daily mean streamflow at calibration sites $A$, Segreganset River near Dighton (01109070); $B$, Matfield River at Elmwood, East Bridgewater (01106500); and C, Poor Meadow Brook at South Hanson (01106900). 
A. Segreganset River near Dighton (01109070)

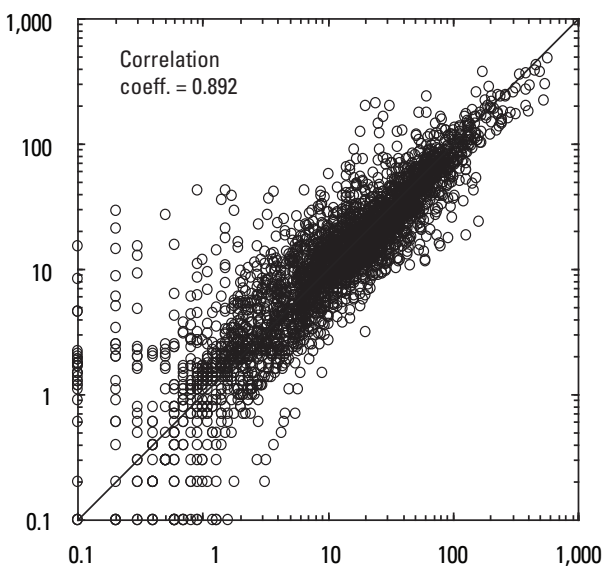

B. Matfield River at Elmwood, East Bridgewater (01106500)
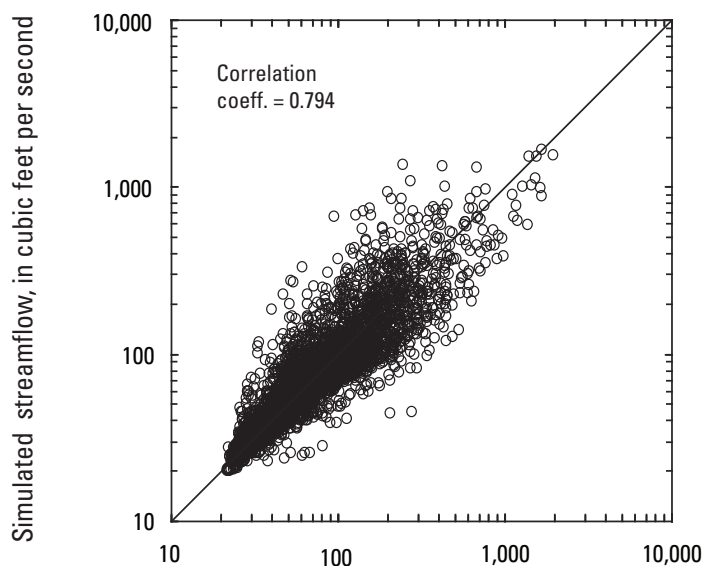

C. Poor Meadow Brook at South Hanson (01106900)

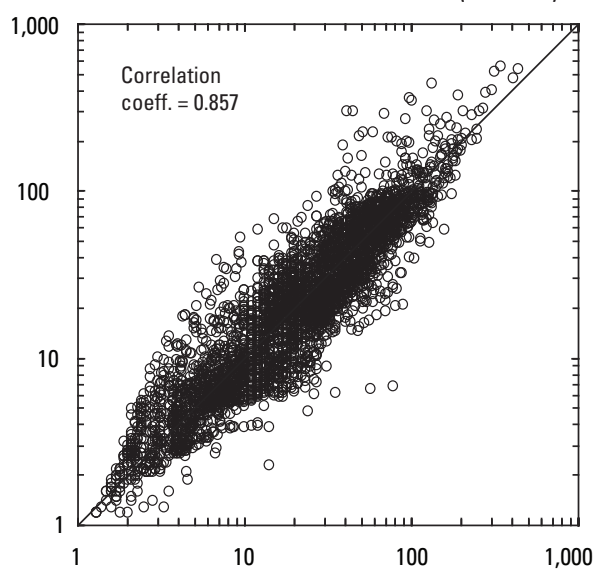

Observed streamflow, in cubic feet per second

Figure 1-6. Observed and simulated daily mean streamflow at calibration sites $A$, Segreganset River near Dighton (01109070); $B$, Matfield River at Elmwood, East Bridgewater (01106500); and C, Poor Meadow Brook at South Hanson (01106900).
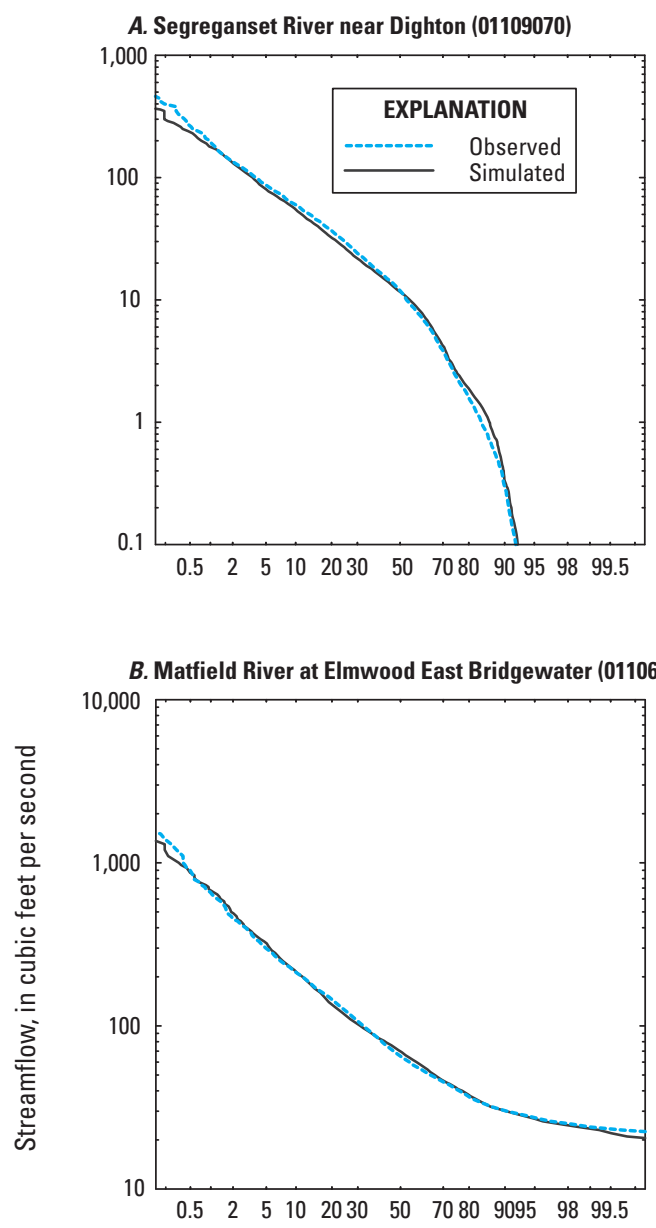

C. Poor Meadow Brook at South Hanson (01106900)

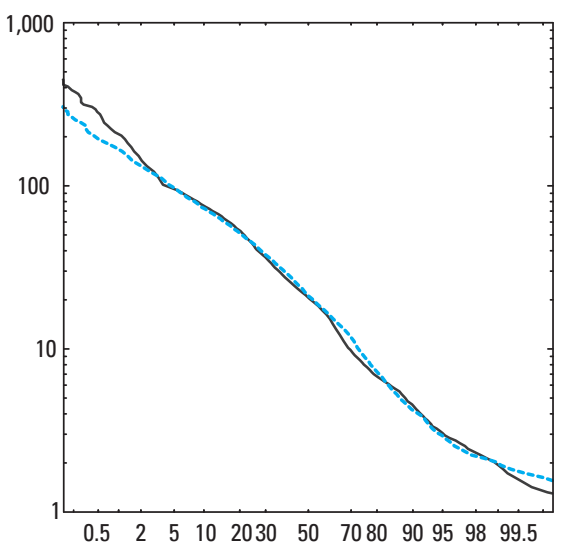

Percentage of time streamflow equaled or exceeded

Figure 1-7. Observed and simulated daily mean streamflow at calibration sites $A$, Segreganset River near Dighton (01109070); $B$, Matfield River at Elmwood, East Bridgewater (01106500); and C, Poor Meadow Brook at South Hanson (01106900). 


\section{Model Limitations}

Numerical watershed models necessarily simplify the complex processes and physical characteristics of a basin. Nonetheless, the model can be used effectively to address many water-resource management questions, provided that the limitations and uncertainties are considered. One uncertainty associated with complex watershed models such as HSPF is the possibility of constructing models with differing structures and parameter values that produce equally acceptable results. Uncertainty also is inherent in the data used to develop and calibrate the model. These include climate data, streamflow data, water-use data, channel-geometry and other hydraulic data used to construct FTABLEs, and the geospatial data used to define the HRUs.

Uncertainty in the climate data results from (1) the use of point measurements to represent variables that have a high degree of spatial variability, (2) the presence of regional climatic differences across the basin, (3) the presence of systematic measurement bias, or (4) some combination of these factors. Extrapolating a point measurement of precipitation over a large area of the basin disregards the spatial variability of the intensity and duration of precipitation events. The precipitation data from Taunton Municipal Airport (KTAN) generally provided better agreement between simulated and observed flows than the data from T.F. Green Airport (KPVD). The uncertainties in the climate data may lead to error in simulating storms and daily streamflow in the basin.

Uncertainty in water-use data and simplification of the complexities of water use in the basin also affect calibrated parameter values. Known water withdrawals are removed directly from simulated streamflow. Similarly, known wastewater-return flows are added directly to simulated streamflow. For time-varying ground-water withdrawals, streamflow depletion was first calculated with the STRMDEPL program, which is subject to several simplifying assumptions; the accuracy of streamflow depletion calculated in this manner depends on the degree to which the underlying assumptions of STRMDEPL are met. Measured data were sparse for golfcourse and cranberry-bog irrigation withdrawals, and the withdrawals could only be estimated. Residential water-use rates were based on household population densities, and per capita water-use estimates were obtained from other studies. Once these disparate water uses are accounted for in the model, the parameter values are adjusted to calibrate the model's response to precipitation and evapotranspiration. Therefore, parameter values can be skewed during calibration to compensate for inaccuracies in the water-use data or inadvertent omission of major withdrawals or returns.

Model calibration and performance reflect the combined response of the PERLNDs, IMPLNDs, and reaches used to represent the basin. Most HSPF parameters, as well as IMPLND areas, cannot be measured independently and are obtained through the calibration process. In general, judgment based on hydrologic experience and results from previous HSPF studies are used to determine the parameter values for individual HRUs. Although agreement was good between observed and simulated flows for a wide range of flow conditions and HRU combinations, information was not available to calibrate individual HRUs. Therefore, simulation results from analyses in which flow from an individual type of HRU is of interest (such as for a water-quality study) have a relatively high degree of uncertainty and should be interpreted cautiously to avoid reaching inaccurate conclusions.

Stage, storage, and discharge characteristics of stream reaches are determined from measured channel geometry to the extent possible, but the spatial variability of these characteristics cannot be measured or fully represented in the model. Similarly, stage, storage, and discharge characteristics of reservoir and wetland reaches were determined from available data to the extent possible; but for most reaches, these data were not available and their values could only be estimated. Reservoir-management activities, such as seasonal waterlevel changes for recreational purposes or regulation for flood control or water-supply management, and run-of-river diversions for power generation or industrial use, also were not represented in the model. As part of the calibration process, storage-discharge relations were adjusted empirically in the three reaches with observed streamflow data; direct calibration of the other 17 reaches was not conducted. Consequently, simulation results from ungaged areas of the basin have a relatively high degree of uncertainty.

\section{References Cited}

Alley, W.M., and Veenhuis, J.E., 1983, Effective impervious area in urban runoff modeling: Journal of Hydraulic Engineering, v. 109, no. 2, p. 313-319.

Arcement, G.J., Jr., and Schneider, V.R., 1989, Guide for selecting Manning's roughness coefficients for natural channels and flood plains: U.S. Geological Survey WaterSupply Paper 2339, 38 p.

Barbaro, J.R., and Zarriello, P.J., 2006, A precipitation-runoff model for the Blackstone River Basin, Massachusetts and Rhode Island: U.S. Geological Survey Scientific Investigations Report 2006-5213, 85 p.

Barlow, P.M., 2000, Documentation of computer program STRMDEPL - A program to calculate streamflow depletion by wells using analytical solutions, in Zarriello, P.J., and Ries, K.G., III, 2000, A precipitation runoff model for the analysis of the effects of water withdrawals on streamflow, Ipswich River Basin, Massachusetts: U.S. Geological Survey Water-Resources Investigations Report 00-4029, $99 \mathrm{p}$. 
Barlow, P.M., Ahlfeld, D.P., and Dickerman, D.C., 2003, Conjunctive-management models for sustained yield of stream-aquifer systems: Journal of Water Resources Planning and Management, v. 129, no. 1, p. 35-48.

Bicknell, B.R., Imhoff, J.C., Kittle, J.L., Jr., Jobes, T.H., and Donigian, A.S., Jr., 2000, Hydrological Simulation Program-FORTRAN User's manual for release 12: Mountain View, Calif., AQUA TERRA Consultants, variously paged.

Carlson, C.S., and Lyford, F.P., 2004, Simulated ground-water flow for a pond-dominated aquifer system near Great Sandy Bottom Pond, Pembroke, Massachusetts: U.S. Geological Survey Scientific Investigations Report 2004-5269, 43 p.

Chow, V.T., 1959, Open-channel hydraulics: New York, McGraw-Hill Book Company, Inc., 680 p.

Coon, W.F., 1998, Estimation of roughness coefficients for natural stream channels with vegetated banks: U.S. Geological Survey Water-Supply Paper 2441, 133 p.

Donigian, A.S., Imhoff, J.C., Bricknell, B.R., and Kittle, J.L., Jr., 1984, Application guide for Hydrological Simulation Program-FORTRAN (HSPF): Athens, Ga., U.S. Environmental Protection Agency-600/3-84-065, Environmental Research Laboratory, 177 p.

Federal Emergency Management Agency, 1994, Water control infrastructure, national inventory of dams: 1993-94 CD-ROM.

Granato, G.E., 2009, Computer programs for obtaining and analyzing daily mean streamflow data from the U.S. Geological Survey National Water Information System Web Site: U.S. Geological Survey Open-File Report 2008-1362, 123 p., on CD-ROM, 5 appendixes.

Hirsch, R.M., 1982, A comparison of four streamflow record extension techniques: Water Resources Research, v. 18, no. 4 , p. 1081-1088.

Jensen, M.E., and Haise, H.R., 1963, Estimating evapotranspiration from solar radiation: Proceedings of the American Society of Civil Engineers, Journal of Irrigation and Drainage, v. 89, no. IR4, p. 15-41.

Korzendorfer, B.A., and Horn, M.A., 1995, Estimated water use in the New England States, 1990: U.S. Geological Survey Water-Resources Investigations Report 94-4252, $21 \mathrm{p}$.

Lapham, W.W., 1988, Yield and quality of ground water from stratified-drift aquifers, Taunton River Basin, Massachusetts: U.S. Geological Survey Water ResourcesInvestigations Report 86-4053, 69 p.

Leopold, L.B., 1994, A view of the river, Cambridge, Mass., Harvard University Press, 298 p.
Love, J.T., and Donigian, A.S., Jr., 2002, The Connecticut watershed model-Model development, calibration, and validation: presented at WEF-Watershed 2002, February 23-27, 2002, Ft. Lauderdale, Fla.

Lumb, A.M., McCammon, R.B., and Kittle, J.L., Jr., 1994, User's manual for an expert system (HSPEXP) for calibration of the Hydrological Simulation ProgramFORTRAN: U.S. Geological Survey Water-Resources Investigations Report 94-4168, 102 p.

Martin, G.R., Zarriello, P.J., and Shipp, A.A., 2001, Hydrologic and water-quality characterization and modeling of the Chenoweth Run Basin, Jefferson County, Kentucky: U.S. Geological Survey Water-Resources Investigations Report, 00-4239, 197 p.

Massachusetts Department of Fish and Game, 2008, Southeast District pond maps: Massachusetts Division of Fisheries and Wildlife, accessed 2008, at http://www.mass.gov/ dfwele/dfw/habitat/maps/ponds/pond_maps_sd.htm.

Massachusetts Office of Geographic Information (MassGIS), 2008a, Land use data layer and metadata: Office of Geographic Information (MassGIS), accessed 2008, at http://www.mass.gov/mgis/lus.htm.

Massachusetts Office of Geographic Information (MassGIS), 2008b, Surficial geology data layer and metadata: Office of Geographic Information (MassGIS), accessed 2008, at http://www.mass.gov/mgis/sg24k.htm.

Massachusetts Office of Geographic Information (MassGIS), 2008c, Wetland data layer and metadata: Office of Geographic Information (MassGIS), accessed 2008, at http://www.mass.gov/mgis/wetdep.htm.

Massachusetts Office of Geographic Information (MassGIS), 2008d, Datalayers from the 1990 U.S. Census-December 1995: Office of Geographic Information (MassGIS), accessed 2008, at http://www.mass.gov/mgis/cen1990_ blocks.htm.

Regan, R.S., and Schaffranek, R.W., 1985, A computer program for analyzing channel geometry: U.S. Geological Survey Water-Resources Investigations Report 85-4335, $40 \mathrm{p}$.

Rosenberry, D.O., Stannard, D.I., Winter, T.C., and Martinez, M.L., 2004, Comparison of 13 equations for determining evapotranspiration from a prairie wetland, Cottonwood Lake area, North Dakota, USA: Wetlands, v. 24, no. 3, p. 483-497.

U.S. Environmental Protection Agency, 2000, Estimating hydrology and hydraulic parameters for HSPF, Basins Technical Note 6: EPA-823-R00-012, 32 p. 
Zarriello, P.J., and Bent, G.C., 2004, A precipitation-runoff model for the analysis of the effects of water withdrawals and land-use change on streamflow in the UsquepaugQueen River Basin, Rhode Island: U.S. Geological Survey Scientific Investigations Report 2004-5139, 75 p.

Zarriello, P.J., and Ries, K.G., III, 2000, A precipitation-runoff model for analysis of the effects of water withdrawals on streamflow, Ipswich River Basin, Massachusetts: U.S. Geological Survey Water-Resources Investigations Report, 00-4029, $99 \mathrm{p}$. 
THIS PAGE INTENTIONALLY LEFT BLANK 


\section{Appendix 2. Water-Quality Data}

Appendix 2 table is available here in the Excel format (.xls) 
Prepared by the Pembroke and Lafayette Publishing Service Centers.

For more information concerning this report, contact:

Office Chief

U.S. Geological Survey

New England Water Science Center

Massachusetts-Rhode Island Office

10 Bearfoot Road

Northborough, MA 01532

dc_ma@usgs.gov

or visit our Web site at:

http://ma.water.usgs.gov 

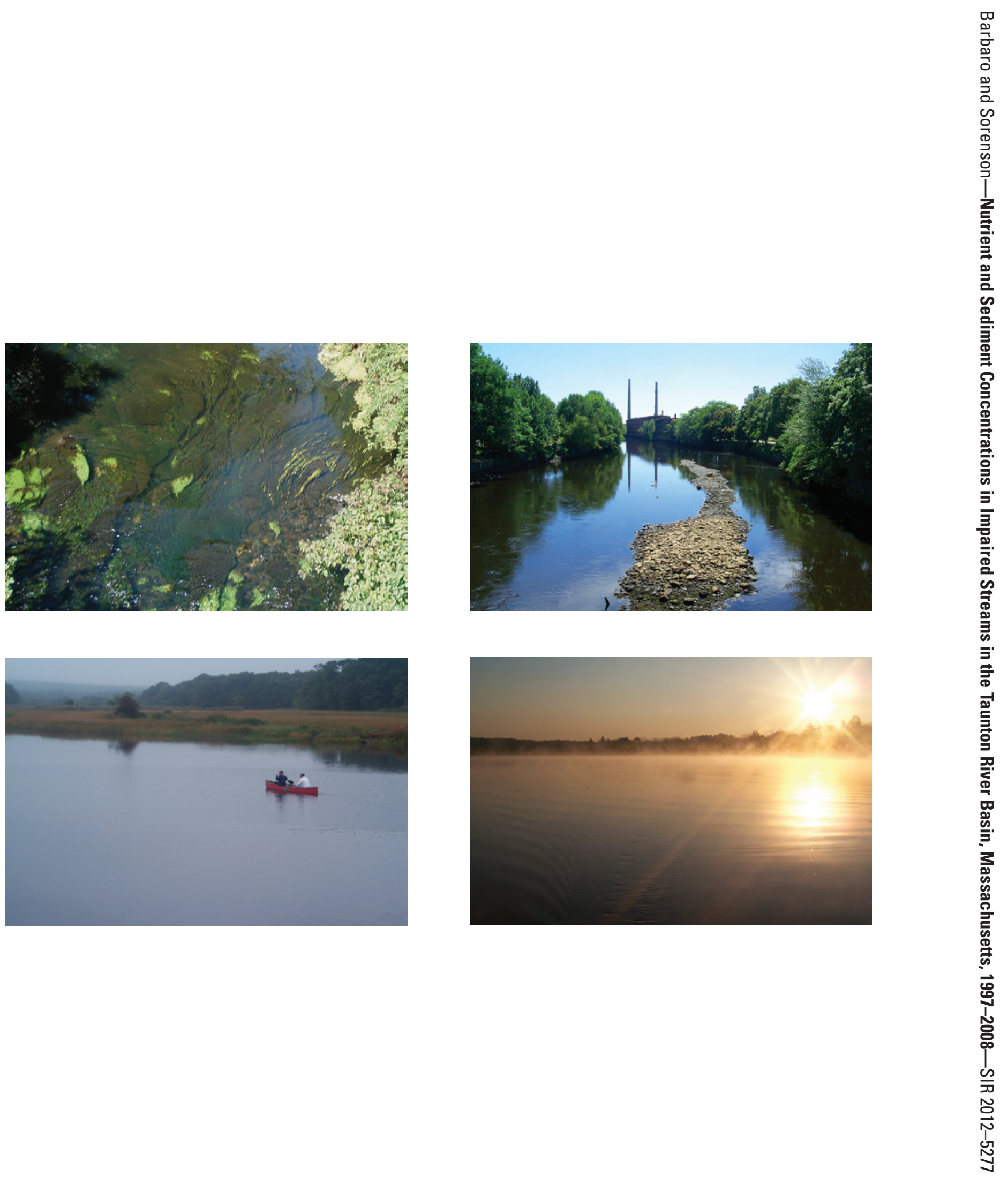